Florida International University FIU Digital Commons

FIU Electronic Theses and Dissertations

University Graduate School

$3-6-2012$

\title{
History and Evolutionary Trajectory of the Iranian Nuclear Program
}

Mohammad Homayounvash

Florida International University

DOI: $10.25148 /$ etd.FI12050230

Follow this and additional works at: https://digitalcommons.fiu.edu/etd

\section{Recommended Citation}

Homayounvash, Mohammad, "History and Evolutionary Trajectory of the Iranian Nuclear Program" (2012). FIU Electronic Theses and Dissertations. 624.

https://digitalcommons.fiu.edu/etd/624

This work is brought to you for free and open access by the University Graduate School at FIU Digital Commons. It has been accepted for inclusion in FIU Electronic Theses and Dissertations by an authorized administrator of FIU Digital Commons. For more information, please contact dcc@fiu.edu. 


\section{FLORIDA INTERNATIONAL UNIVERSITY}

Miami, Florida

\section{HISTORY AND EVOLUTIONARY TRAJECTORY OF THE IRANIAN NUCLEAR}

\section{PROGRAM}

A dissertation submitted in partial fulfillment of the

requirements for the degree of

DOCTOR OF PHILOSOPHY

in

INTERNATIONAL RELATIONS

by

Mohammad Homayounvash 
To: Dean Kenneth Furton

College of Arts and Sciences

This dissertation, written by Mohammad Homayounvash, and entitled History and Evolutionary Trajectory of the Iranian Nuclear Program, having been approved in respect to style and intellectual content, is referred to you for judgment.

We have read this dissertation and recommend that it be approved.

Nicholas Onuf

Thomas Breslin

Benjamin Smith

Mohiaddin Messbahi, Major Professor

Date of Defense: March 6, 2012

The dissertation of Mohammad Homayounvash is approved.

Dean Kenneth G. Furton

College of Arts and Sciences

Dean Lakshmi N. Reddi

University Graduate School

Florida International University, 2012 
(C) Copyright 2012 by Mohammad Homayounvash

All rights reserved. 


\section{DEDICATION}

I dedicate this thesis to my parents, family, and colleagues at Florida International University without whose generous emotional and intellectual support it would not have come to fruition. 


\section{ACKNOWLEDGMENTS}

I wish to thank all members of my committee for patiently and smoothly guiding me throughout the research and writing phases of the present work. Special gratitude should go to Dr. Mohiaddin Messbahi whose intellectual brilliance, generous mentorship, and inspiring lectures have been at the genesis of the present work and have guided it throughout. I would also like to thank Dr. Thomas Breslin for providing invaluable historiographical methodology and archival research advice. I have also benefitted from Dr. Nicholas Onuf's theoretical insights and inspiring works and words. 


\section{ABSTRACT OF THE DISSERTATION \\ HISTORY AND EVOLUTIONARY TRAJECTORY OF THE IRANIAN NUCLEAR \\ PROGRAM}

by

Mohammad Homayounvash

Florida International University, 2012

Miami, Florida

Professor Mohiaddin Messbahi, Major Professor

What actors and processes at what levels of analysis and through what mechanisms have pushed Iran's nuclear program (INP) towards being designated as a proliferation threat (securitization)? What actors and processes at what levels of analysis and through what mechanisms have pushed Iran's nuclear program away from being designated as an existential threat (de-securitization)? What has been the overall balance of power and interaction dynamics of these opposing forces over the last half-century and what is their most likely future trajectory?

Iran's nuclear story can be told as the unfolding of constant interaction between state and non-state forces of "nuclear securitization" and "nuclear de-securitization." Tracking the crisscrossing interaction between these different securitizing and desecuritizing actors in a historical context constitutes the central task of this project.

A careful tracing of "security events" on different analytical levels reveals the broad contours of the evolutionary trajectory of INP and its possible future path(s). Out of this theoretically conscious historical narrative, one can make informed observations about the overall thrust of INP along the securitization -- de-securitization continuum. 
The main contributions of this work are three fold: First, it brings a fresh theoretical perspective on Iran's proliferation behavior by utilizing the "securitization" theory tracing the initial indications of the threat designation of INP all the way back to the mid 1970s. Second, it gives a solid and thematically grounded historical texture to INP by providing an intimate engagement with the persons, processes, and events of Tehran's nuclear pursuit over half a century. Third, it demonstrates how INP has interacted with and even at times transformed the NPT as the keystone of the nonproliferation regime, and how it has affected and injected urgency to the international discourse on nuclear proliferation specifically in the Middle East. 


\section{TABLE OF CONTENTS}

CHAPTER

PAGE

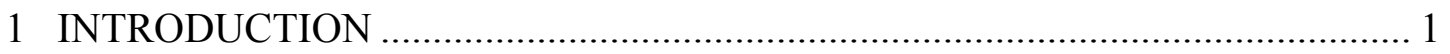

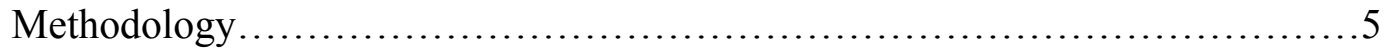

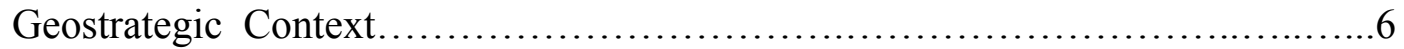

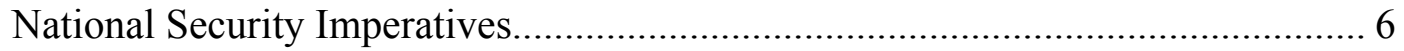

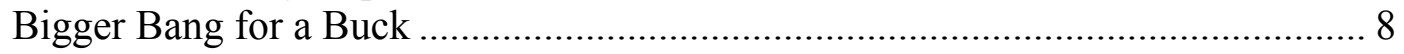

Bureaucratic Causalities............................................................................. 10

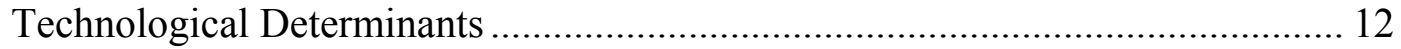

Psychological Context ................................................................................ 14

Conceptual \& Methodological Framework ........................................................... 18

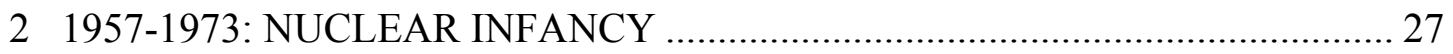

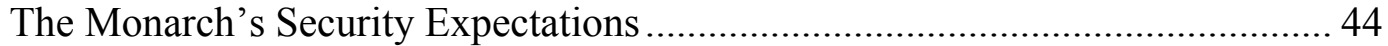

The INP Muddles Through ........................................................................... 49

Deterrence Creeps into the Monarch's Security Lexicon ....................................... 57

3 1974-1978: NUCLEAR EXUBERANCE ………………………………......... 72

Establishment of the AEOI and the Indian PNE............................................ 73

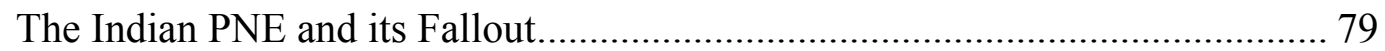

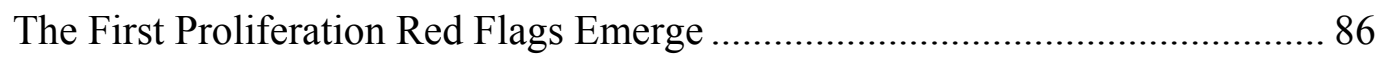

Tehran's Nuclear Standoff with Washington ..................................................... 91

Lame-duck Ford Replaced by Anti-Nuclear Carter.......................................... 121

The India Resemblance Raises More Eyebrows............................................. 135

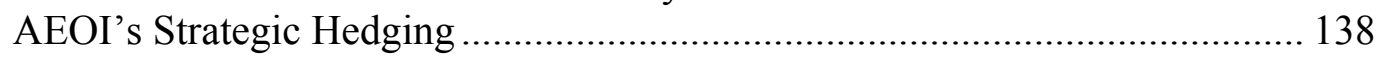

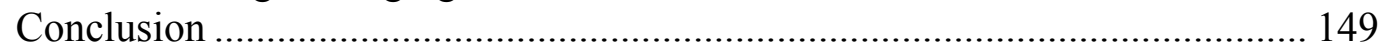

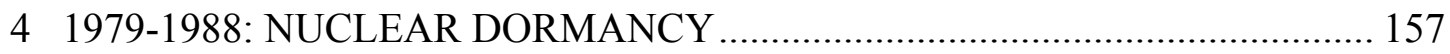

Securitization of the INP Gains Momentum............................................... 170

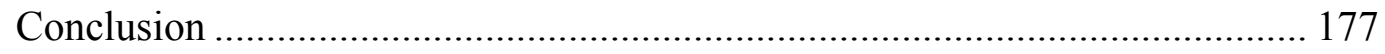

5 1988-1997 NUCLEAR EXPEDIENCY …………………............................ 187

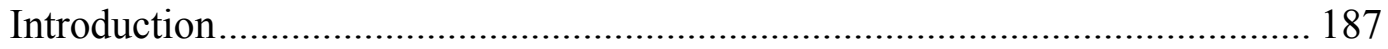

The Soviet Collapse and the Cottage Industry of Securitizing the INP.............. 189

Clinton and "Dual Containment"........................................................................ 194

INP's Russia Connection Sends Securitization to New Heights ......................... 201

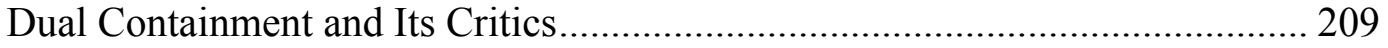

A Shift from the BNPP to MRBMs ............................................................. 216

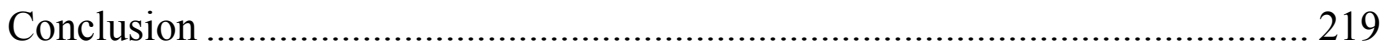

6 1997-2011: NUCLEAR APPEASEMENT \& FLAMBOYANCY …………….... 224

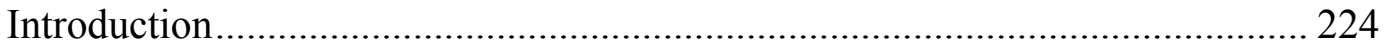

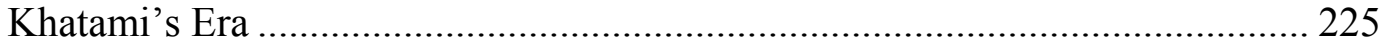

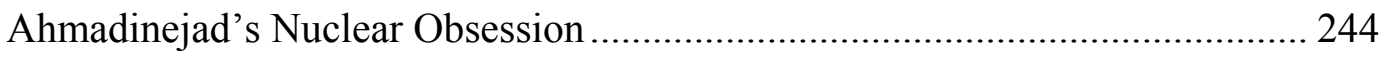


Iran's IAEA and UNSC Dilemma ............................................................. 246

INP's Covert Militarization and Domestic De-Nationalization........................ 253

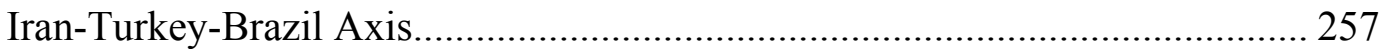

INP Enters Kinetic Militarization Zone ....................................................... 259

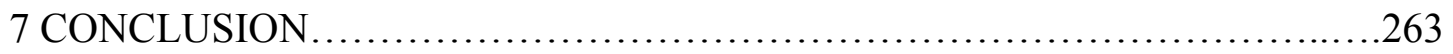

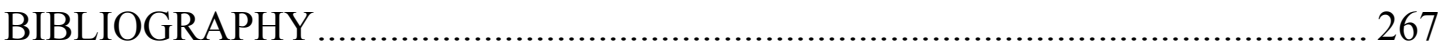

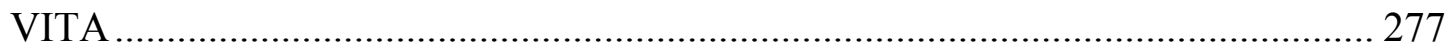




\section{LIST OF ABBREVIATIONS AND ACRONYMS}

ACDA - Arms Control and Disarmament Agency

AEC-Atomic Energy Commission

AEOI-Atomic Energy Organization of Iran

AMUT - Aryamehr University of Technology

BARC - Bhabha Atomic Research Centre

BNPP_Bushehr Nuclear Power Plant

CENA - Comisión Nacional de Energía Atómica

CENTO_Central Treaty Organization

CTR - Cooperative Threat Reduction

DIA-Defense Intelligence Agency

DCI - Director of National Intelligence

ENTEC_-Esfahan Nuclear Technology Center

FBR_-Fast Breeder Reactor

FSU-Former Soviet Union

HEU— Highly Enriched Uranium

HIM—His Imperial Majesty

IAEA - International Atomic Energy Agency

IAF-Israeli Air Force

IIN_ Imperial Iranian Navy

IITK - Indian Institute of Technology Kanpur

INP_-Iranian Nuclear Program

IRGC - Iranian Revolutionary Guard Corps 
KWU— Kraftwork Union

LWR— Light Water Recators

MAA — Military Assistance Advisory Groups

MKO-Mojahedin-e-Khalq Organization (aka MEK)

MRBM - Medium-Range Ballistic Missile

MTCR — Missile Technology Control Regime

MWe-Megawatt Electrical

MWth-Megawatt Thermal

NCA - Nuclear Cooperation Agreement

NIE-National Intelligence Estimate

NNWS-Non-Nuclear Weapons State

NPT—Non-Proliferation Treaty

NSDM — National Security Decision Memorandum

NSG - Nuclear Suppliers Group

NSSM — National Security Study Memorandum

NWFZ- Nuclear Weapons Free Zone

NWS- Nuclear Weapons State

ORNL- Oak Ridge National Lab

PAEK - Pakistan Atomic Energy Commission

PNE—Peaceful Nuclear Explosion

PWR — Pressurized Water Reactor

RCD— Regional Cooperation for Development

SEA-Southeast Asia 
SNIE - Special National Intelligence Estimate

TAFT— Technical Assistance Field Team

TRR - Tehran Research Reactor

UCF-Uranium Conversion Facility

UCOR - South African Uranium Enrichment Corporation

UNGA-United Nations General Assembly

VNSA—Violent Non-State Actor 


\section{CHAPTER 1}

\section{INTRODUCTION}

"On March 6 [1957] the U.S. Atomic Energy Commission and the Department of State announced that representatives of Iran and the United States on March 5 signed a proposed agreement for cooperation in research in the peaceful uses of atomic energy. The signing was announced in Iran by His Imperial Majesty, the Shah, at the opening ceremony of the U.S. atoms-for-peace exhibit at Tehran on March 6;" ${ }^{1}$ So reads the Department of State Bulletin 36, April-June 1957. This event marks the official inauguration of Iran's nuclear journey whose initial phase, both conceptually and operationally, was all but humble.

Almost a half-century later, on July 31, 2006, The UN Security Council (UNSC) adopted resolution 1696 "seriously concerned that the International Atomic Energy Agency (IAEA) was still unable to provide assurances about Iran's undeclared nuclear material and activities after more than three years, demand(ing) that Iran suspend all enrichment-related and reprocessing activities, including research and development, and (giving) it one month to do so or face the possibility of economic and diplomatic sanctions to give effect to its decision." ${ }^{2}$ The UNSC resolution marks the official internationalization of a U.S. sponsored and led securitization campaign to designate the Iranian nuclear program (INP) as a credible existential threat whose trajectory should be deterred from going "rogue" at any cost.

\footnotetext{
${ }^{1}$ U.S. Department of State, "Atoms for Peace Agreement with Iran," (Department of State Bulletin 36, Washington DC: 15 April 1957), 629. The agreement was signed at 2:30 p.m. on March 5, 1957 by Ali Amini, the Iranian Ambassador to the United States, Lewis Strauss, Chairman of the United States Atomic Energy Commission, and William Rountree, Assistant Secretary of the State.

${ }^{2}$ Resolution 1696 (2006) Adopted by the Security Council at its 5500th meeting, United Nations, July 31, 2006, http://www.un.org/News/Press/docs/2006/sc8792.doc.htm (accessed January 10, 2010).
} 
Panoramically viewed, these two watershed events punctuate the atomic odyssey Iran embarked upon over a half century ago, a still unfolding voyage of selfdiscovery for both the Iranian state and the Iranian nation whose coming to conceptual and operational grips with the atom has gone through a most tumultuous and tortuous path. The present work is an attempt to give a security-textured narrative of how the Iranian state set off on the nuclear road, how its nuclear consciousness evolved (selfreferentially and in interaction with the international system) under the Shah and in the first decade of the Islamic Republic era.

The study is based on extensive archival research at the National Archives in College Park, Maryland, the Richard Nixon Presidential Library in Yorba Linda, California, and the Ronald Reagan Presidential Library in Simi Valley, California. It has also benefitted from the National Security Archive documents collected and published by the George Washington University (GWU). The declassified documents edited by William Burr at the National Security Archive's Project on Nuclear Documentation have been thoroughly examined as they shed the most illuminating light on the nuclear dynamics between the Ford and Carter administrations and the Shah's regime.

To complement the aforementioned material, I have examined relevant documents in the CIA Records Search Tool (CREST) at the National Archives in College Park and the FOIA (Freedom of Information Act) Electronic Reading Room at http://www.foia.cia.gov/. The CIA materials, although few and far between, proved especially critical as they shed light on the intelligence side of the INP and demonstrate crucial points of divergence in judgment between the U.S. intelligence community and the conventional wisdom on the Islamic Republic's predilection for proliferation and 
weaponization especially in the Islamic Republic era. The 2007 National Intelligence Estimate (NIE) was one such document whose crucial impact in retarding the drifting of Iran's nuclear dispute to a military conflict could hardly be overstated.

A note of caution on the intelligence side of the INP is in order here though. As National Security Archive senior analyst William Burr has noted, for the most part, CIA documents on the INP are yet to be declassified and without them one can not shed definitive light on the reasoning behind the Ford and Carter administrations' arrièrepensée in demanding from Iran safeguards beyond those stipulated by the IAEA before they could sell nuclear reactors to the Shah. Access to those materials assumes even more significance once one realizes that the CIA had an intelligence attaché in Tehran in the late 1970's exclusively tasked with monitoring the INP and the Shah's long-term nuclear intentions. $^{3}$

Additional materials, especially media accounts on the post-revolution era, have been gathered from the CIA's Foreign Broadcast Information Service (FBIS) and its successor, the Open Source Center's (OSC) World News Connection (WNC) that contain invaluable primary and secondary source intelligence data on the INP obtained from mass media outlets across the globe. I have used the British Broadcasting Corporation (BBC) Monitoring to supplement the FBIS and OSC materials. Important nuggets of data were also found at the Nuclear Threat Initiative's (NTI) profile on the chronology of Iran's nuclear program. I have also used the Vanderbilt Television News Archive to gain more context about the conventional wisdom on the evolutionary trajectory of the INP.

\footnotetext{
${ }^{3}$ Assad Homayoun, interview by Mohamad Homayounvash, trans. Mohammad Homayounvash, Washington D.C. (July 23, 2010).
} 
Furthermore and to fill in possible gaps on the Iranian side of the story, a wide net was cast to capture material from Persian sources. One invaluable source was Gholam Reza Afkhami's interview with the founding figure of the Iranian nuclear program, Akbar Etemad, published by the Foundation for Iranian Studies in 1997. The biographical interview accounts collected by Harvard University's Iranian Oral History Project and The Foundation for Iranian Studies also contained significant insights into the Shah's nuclear program on which the Persian paper trail is extremely scarce and sporadic. ${ }^{4}$ For media accounts on the post-Revolution era, I have used Iranian government-affiliated websites, newspaper archives, and news websites.

To engage the INP more intimately and to supplement the primary archival material and secondary sources, I have also conducted a number of in-depth interviews with a number of key observers of the INP. These individuals are part of a steadily growing epistemic community that has formed, over the years, around Iran's nuclear enterprise and their expert judgments reflect and shape the past and the future of the INP. Prominent among the interviewees are Gary Sick who served on the National Security Council in the Ford, Carter, and Reagan administrations, Hans Blix, former head of the International Atomic Energy Agency (IAEA), Ahmad Kamal, Pakistani Ambassador to the UN (1995-1999), Assad Homayoun, former Iranian diplomat in charge of political affairs in the Iranian Embassy in Washington under the Shah, Behrad Nakhai, a former Research Scientist at Oak Ridge National Laboratory and a prominent nuclear safety

\footnotetext{
${ }^{4}$ One reason for the paucity of paper trail in the Shah's era, as former Iranian diplomat Dr. Assad Homayoun mentioned, was that the majority of top strategic decisions on the nuclear issue were made directly and esoterically by the Shah and only then orally conveyed to the respective authorities for execution. Assad Homayoun, interview by Mohamad Homayounvashtrans. Washington D.C. (July 23, 2010). This situation continued in the Islamic Republic era as the strategic-level nuclear decision making was completely privatized by the Supreme Leader.
} 
expert, and Muhammad Sahimi, a Professor of Chemical Engineering and Materials Science at the University of Southern California in Los Angeles.

\section{Methodology}

The Iranian Nuclear Program (INP) has captured the epicenter of international proliferation discourse and practice for nearly a decade now. This has given rise to a sizable body of literature on various aspects of Iran's nuclear bid oftentimes geared toward "divining" Iran's strategic nuclear intentions and the determinants "driving" them both prior to and after the 1979 Iranian Revolution.

This mode of analysis is generally in synch with how the question of nuclear proliferation is treated in International Relations (IR) theory. A survey of theoretically informed works on nuclear proliferation reveals two broad schools of thought: those who take an outward looking approach and afford primacy to the geostrategic context of nuclearization and those who turn their beam of inquiry inward giving precedence to the psychological context of the state's top decision making apparatus.

As viewed by the first school of thought, the geostrategic context of the state is the external strategic environment within which the state forms and performs its national security ambitions and decisions. IR theories drawing on this environment to account for a state's nuclear behavior give pride of place, varyingly, to national security imperatives, economic inducements, bureaucratic causalities, and technological determinants. ${ }^{5}$

\footnotetext{
${ }^{5}$ For a pithy and lucid illustration of these factors, see Joseph Cirincione, Bomb Scare: The History and Future of Nuclear Weapons (New York: Colombia University Press, 2007). Other important works include Avery Goldstein, "Robust and Affordable Security: Some Lessons from the Second-Ranking Powers During the Cold War ," Journal of Strategic Studies, 15, no. 4 (1992): 476 - 527 . David Albrigh, "South Africa and the Affordable Bomb," Bulletin of the Atomic Scientists 50, no. 4 (July/August 1994). Peter R. Lavoy, "Nuclear Myths and the Causes of Nuclear Proliferation," Security Studies 2, no. 3, 4 (September 1993): 210. Graham T. Allison and Morton H. Halperin, "Bureaucratic Politics: A Paradigm and Some Policy Implications," World Politics, 24 (1972): 40-79. As applied to Iran, see Shahram Chubin, Iran's Nuclear Ambitions (Washington, D.C.: Carnegie Endowment for International Peace, 2006). Trita Parsi,
} 
On the other hand, the psychological context is defined by the "national cognitive space" in which ultimate nuclear decision-makers operate. This psychological context is populated by civilizational and/or national identity conceptions and symbols whose interaction with the geostrategic context defines the crystilization moment at which the ultimate momentous decision to go nuclear is finalized. ${ }^{6}$

With this conceptual template at hand, the following pages put forth a survey of the explanatory framworks on proliferation and their applicability to the INP.

\section{Geostrategic Context}

\section{National Security Imperatives}

Different strands of realist IR theory dominate the national security analytical models on proliferation. Kenneth Waltz, for example, provides five major security imperatives to explain the spread of nuclear weapons. These include counterbalancing mechanism by great powers (the USSR); security independence solution (Britain); security guarantee for a strategically lonely and atomically threatened state (China and Pakistan); deterrence against conventionally superior adversaries (Israel); and security independence solution at an affordable price (India). ${ }^{7}$ As Scott Sagan pithily puts it,

Treacherous Alliance: The Secret Dealings of Israel, Iran, and the United States (Yale University Press, 2007). Ray Takeyh and Vali Nasr, "The Costs of Containing Iran: Washington's Misguided New Middle East Policy," Foreign Affairs (The Council on Foreign Relations), January-February 2008. George Perkovich, "Dealing With Iran's Nuclear Challenge," (Carnegie Endowment for International Peace) April 2003: 4.

${ }^{6}$ An excellent generic template is Jacques E. C. Hymans, The Psychology of Nuclear Proliferation: Identity, Emotions and Foreign Policy (Cambridge: Cambridge University Press, 2006). As applied to Iran, see Ardeshir Zahedi, interview by Bijan Farhoudi, IRAN US Relations- Ambassador Ardeshir Zahedi's Historical Perspective, Voice of America (VOA), 2006. Akbar Etemad, Barnameh-ye enerzhi-ye atomi-ye iran, talash-ha va tanesh-ha (Iran's Nuclear Energy Program, Hopes and Challenges), ed. Gholam Reza Afkhami (Bethesda, MD: Bonyad-e Motaleat-e Iran (Foundation for Iranian Studies), 1997).

${ }^{7}$ Kenneth N. Waltz, "Peace, Stability, and Nuclear Weapons,"Policy Papers, Institute on Global Conflict and Cooperation (UC Berkeley, Policy Papers, Institute on Global Conflict and Cooperation, 1995). 
"from this perspective, one can envision the history of nuclear proliferation as a strategic chain reaction." Similarly, John Mearsheimer, writing in the offensive realist spirit, views nuclear weapons as "the surest means of security," arguing that: "Conventional wars can be won rather cheaply; nuclear war cannot, because neither side can escape devastation by the other, regardless of what happens on the battlefield. Thus the incentives to avoid war are of another order of intensity in a nuclear world than they are in a conventional world."

Considering Iran's geostrategic location in an institutionally securitized Middle East and its antagonistic relationship with the United States over the last three decades, the security paradigm has been extensively applied to analyzing the Iranian nuclear program after the Iranian Revolution of 1979. Writing in this spirit, for example, Ray Takeyh and Vali Nasr blame Iran's regional security environment for its nuclear behavior. ${ }^{10}$ From this perspective, the best counter-proliferation strategy against the INP is to remove those strategic anxieties facing the Islamic Republic and once that has happened, the nuclear challenge will, as it were automatically, take care of itself.

This approach, however, is not only too mechanical and deterministic in blaming the external environment for Iran's nuclear behavior, but strikes one as oblivious to internal determinants of Tehran's nuclear bid. Furthermore, as Trita Parsi cogently argues, nuclear weaponization will likely intensify Iran's security anxieties rather than

\footnotetext{
${ }^{8}$ Scott D. Sagan, "Why Do States Build Nuclear Weapons?: Three Models in Search of a Bomb," International Security 21, no. 3 (1996-97): 58.

${ }^{9}$ John J. Mearsheimer, " Why We Will Soon Miss The Cold War," The Atlantic Monthly 266, no. 2 (August 1990): 35-50 .

${ }^{10}$ Ray Takeyh and Vali Nasr, "The Costs of Containing Iran: Washington's Misguided New Middle East Policy," Foreign Affairs (The Council on Foreign Relations), January-February 2008.
} 
assuage them: "As long as the Middle East is kept as free as possible from nuclear weapons, Iran will enjoy a conventional superiority vis-à-vis its neighbors because of its size and resources," he argues. "However, if Iran weaponizes, it will risk sparking a nuclear arms race that may lead small states such as Bahrain and Kuwait to opt for a nuclear capability as well. In such a Middle East, Iran would lose its conventional superiority and find itself at strategic parity with states less than one twentieth its size," Parsi concludes. ${ }^{11}$ Therefore, despite having the Waltzian virtues of parsimony and elegance, the Realist one-size-fits-all framework falls fairly short in accounting for Tehran's nonlinear and, at times, counterintuitive nuclear behavior. ${ }^{12}$

\section{"Bigger Bang for a Buck"13}

According to economics-driven proliferation explanations, nukes provide "robust and affordable security."14 Proponents of this school claim, "nuclear weapons are cheaper to develop and to maintain than very large conventional force structures." Costefficiency considerations were purportedly the main reasoning behind choosing nuclear weapons over conventional munitions as NATO's preferred defense strategy against the

\footnotetext{
${ }^{11}$ Trita Parsi, Treacherous Alliance: The Secret Dealings of Israel, Iran, and the United States (Yale University Press, 2007). 265

${ }^{12}$ One such example is Tehran's rejection, in January 2010, of an IAEA-brokered deal to exchange its low enriched uranium (LEU) stockpile for 20 percent enriched fuel plates it needed for the Tehran Research Reactor (TRR) while essentially agreeing to a comparable deal brokered by Turkey and Brazil a few months later.

${ }^{13}$ Joe Cirincione, Bomb Scare: The History and Future of Nuclear Weapons (New York: Colombia University Press, 2007).

${ }^{14}$ Avery Goldstein, "Robust and Affordable security: Some Lessons from the Second-Ranking Powers during the Cold War ," Journal of Strategic Studies, 15, no. 4 (1992): 476 - 527 . See also David Albright, "South Africa and the Affordable Bomb," Bulletin of the Atomic Scientists 50, no. 4 (July/August 1994).
} 
Soviet threat in Western Europe during the Cold War era. ${ }^{15}$ A well-known proponent of this argument is Homi Bhabha, India's famous nuclear scientist who, advocating a nuclear weaponization defense policy for India in 1964, contended, “atomic explosives were some twenty times cheaper than conventional explosives."16

As far as this author is aware, this cost-benefit calculus of nuclear vs. conventional weapons has not been applied to Iran's proliferation behavior in a systematic way. One explanation for this analytical blind spot, especially in the postrevolution era, could be the hyper-securitized framework within which the INP is conventionally conceived.

These hyper-securitized analyses either deliberately or subconsciously center their explanation on an irrational regime with nuclear-adventurous eschatological clerics in charge who are impervious or insensitive to consequentialist calculations. A natural consequence of these analytical biases is uncritically relegating the INP to the psychological realm ${ }^{17}$ or viewing it in apocalyptically offensive terms. ${ }^{18}$ Analyzed as a non-secular, irrational and fatalistic regime, Tehran's nuclear modus operandi is not amenable to rational calculations of cost vs. benefit or risk vs. reward. Perhaps best exemplifying this "mad mullahs" paradigm of thought on the Islamic Republic are professor Bernard Lewis' comments on the inherent un-deterrability of a nuclear Tehran

\footnotetext{
${ }^{15}$ Stephen M. Younger, "Nuclear Weapons in the Twenty-first Century," Internal Report, Los Alamos National Laboratory (2000).

${ }^{16}$ Peter R. Lavoy, "Nuclear Myths and the Causes of Nuclear Proliferation," Security Studies 2, no. 3, 4 (September 1993): 210.

${ }^{17}$ Sharon Begley, Newsweek,"When Nukes Become Sacred: The psychology behind Iranian support for the country's nuclear program.,"January 8, 2010, http://www.newsweek.com/id/229865/output/print (accessed January 25, 2010).

${ }^{18}$ See, among others, John Bolton, Surrender Is Not an Option: Defending America at the United Nations (New York, NY: Threshold Editions, 2008).
} 
along the lines of the USSR during the Cold War era: "MAD, mutual assured destruction, [was effective] right through the Cold War. Both sides had nuclear weapons. Neither side used them, because both sides knew the other would retaliate in kind. This will not work with a religious fanatic [like Ahmadinejad]. For him, mutual assured destruction is not a deterrent, it is an inducement.",19

\section{Bureaucratic Causalities}

Advocates of this school see no reason why nuclear decisions should be lifted above the "messy fray" of bureaucratic interests and organizational pressures within the domestic national security decision-making apparatus. ${ }^{20}$ From this perspective, "bureaucratic actors, with certain vested interests that may or may not be consistent with the broader national interest, ultimately make the case for or against a nuclear weapons program.,"21

The body of literature on the INP utilizing this framework is laser focused on the Islamic Revolutionary Guard Corps (IRGC) commonly referred to as the Sepah. ${ }^{22}$ In this view, while the bureaucratic factor was virtually absent from the Shah's nuclear decision

\footnotetext{
${ }^{19}$ Bernard Lewis quoted in Norman Podhoretz, World War IV: The Long Struggle Against Islamofascism (New York, NY: Doubleday, 2007).

${ }^{20}$ Graham T. Allison and Morton H. Halperin, "Bureaucratic Politics: A Paradigm and Some Policy Implications," World Politics, 24 (1972): 40-79. Also see Scott D. Sagan, "Why Do States Build Nuclear Weapons?: Three Models in Search of a Bomb," International Security 21, no. 3 (1996-97): 54-86.

${ }^{21}$ Joseph Cirincione, Bomb Scare: The History and Future of Nuclear Weapons (New York: Colombia University Press, 2007): 63.

${ }^{22}$ Gregory Giles, "The Islamic Republic of Iran and Nuclear, Biological, and Chemical Weapons," in Planning the Unthinkable: How New Powers Will Use Nuclear, Biological, and Chemical Weapons, ed. Scott Douglas Sagan, James J. Wirtz Peter R. Lavoy (Ithaca, NY: Cornell University Press, 2000).
} 
making M.O., in the post-Revolution era the Sepah encapsulates the interests, ambitions, and inertias of the "pronuclear lobby" in the Islamic Republic's bureaucratic politics. ${ }^{23}$

Although intellectually more adventurous in prying open the black box of Iran's nuclear decision-making apparatus, the near-obsession of the bureaucratic model with the Revolutionary Guards as the monopoly custodians of the INP leaves out a number of other significant players not least among them the Atomic Energy Organization of Iran (AEOI). The latter played a noteworthy institutional role in de-politicizing the INP domestically and in de-securitizing it internationally until the appointment, on 13 February 2011, of Fereydoun Abbasi-Davani (a former IRGC member designated by the UNSC Resolution 1747 as "a person involved in Iran's nuclear or ballistic missile activities") as the head of the AEOI. This appointment stripped the AEOI and its pronouncements on the INP of much of their de-securitizing credibility, as they were not flowing from a purely scientific and technical entity anymore.

From the present work's perspective, attributing and reducing Iran's nuclear bid to the bureaucratic interests of the Sepah pays inadequate attention to the uncommunicative and highly centralized structure of decision-making in Iranian politics where the Supreme Leader reigns truly supreme, unfettered by the bureaucratic impediments traditionally associated with more diffuse power distribution mechanisms. More specifically, this modality of analysis under-appreciates the private, even at times esoteric, fashion in which Iran's strategic nuclear decisions seem to have been formulated. This reality makes discerning Iran's "nuclear innermost circle" a highly speculative exercise since the composition and configuration of the nuclear decision-

\footnotetext{
${ }^{23}$ Charles C. Mayer, "National Security to Nationalist Myth: Why Iran Wants Nuclear Weapons," Thesis (Naval Postgraduate School, 2004).
} 
making circle do not necessarily overlap with the existent distribution of political power relativities among different factions or follow its fluctuations. Consequently, it seems to be the case that the Sepah's role in shaping the Islamic Republic's nuclear behavior at the strategic level has been hyperbolized in the West.

\section{Technological Determinants}

According to this school of thought, there is a causal relationship or proximate correlation between nuclear technology and proliferation as the former acquires and accumulates its own momentum and incrementally translates itself into the latter. ${ }^{24}$ From this perspective, due to the inherent similarity in technology and infrastructural requirements between civilian and military nuclear facilities, nuclear weaponization rather quickly ensues nuclear capacity. The father of the Israeli nuclear program Ernst David Bergmann most cogently drives this argument home: "by developing atomic energy for peaceful uses, you reach the nuclear option. There are no two atomic energies." ${ }^{25}$ In this view, the causal link between technology and weaponization is further reinforced by the military's fascination with the power and prestige attending nuclear weapons.

Implicit in this technologically deterministic diagnosis of proliferation is a lack of faith in international non-proliferation regimes (the NPT and the like) to intervene between "nuclear capacity" and "nuclear weaponization" and institutionally discourage proliferation. Viewed as such, the only way to hold technology in check is technology. In other words, the most reliable antidote against weaponization is development of next

${ }^{24}$ Stephen M. Meyer, The Dynamics of Nuclear Proliferation (Chicago: University Of Chicago Press, 1984).

${ }^{25}$ Quoted in Avner Cohen, Israel and the Bomb (New York, NY: Columbia University Press, 1999). 
generation proliferation-resistant reactors and fuel cycles: an ambitious prospect whose full-fledged realization lies far in the future.

Technological determinism is one of the predominant paradigms within which the INP has been analyzed especially after the 2002 revelations about the INP and Tehran's unflagging insistence on building an indigenous nuclear full fuel cycle infrastructure. Having bought into this paradigm either implicitly or explicitly, prominent figures across the INP epistemic community have assumed an unproblematic straight line from Iran's progressing nuclear advancements to its eventual drift toward weaponization. ${ }^{26}$ One wonders whether this automatic securitization of Iranian nuclear know-how in the West emanates from the United States' nuclear experience where "latent capacity longevity," i.e., the time gap between a latent nuclear capacity and actual nuclear weaponization, ${ }^{27}$ was virtually zero. In this view, America's nuclear socialization is institutionally securitized and president Eisenhower's 1953 Atoms for Peace initiative was, by and large, an unsuccessful attempt in de-securitizing Washington's attitude toward civilian nuclear technology especially by its rivals and adversaries. The Bush Administration's thinly disguised threats aimed at nuclear de-education of Iran through the use of kinetic force snugly fits into this framework. ${ }^{28}$ On the other hand, Tehran's obsession with the

\footnotetext{
${ }^{26}$ Henry D. Sokolski and Patrick Clawson, ed., Checking Iran's Nuclear Ambitions, ed. Henry D. Sokolski and Patrick Clawson (Carlisle, PA,: U.S. Army War College, 2004). John Bolton, Surrender Is Not an Option: Defending America at the United Nations (New York, NY: Threshold Editions, 2008). Anthony H. Cordesman, Iran's Developing Military Capabilities (Washington D.C.: Center for Strategic \& International Studies, 2005). Fore a more moderate assessment of the link between nuclear technology an proliferation see Gary Samore, Iran's Strategic Weapons Programme: A Net Assessment (London: International Institute for Strategic Studies, 2005).

${ }^{27}$ Stephen M. Meyer, The Dynamics of Nuclear Proliferation (Chicago: University Of Chicago Press, 1984).

${ }^{28}$ George W. Bush, Decision Points (New York, NY: Crown Publishers, 2010).
} 
notion of "nuclear independence" and "fuel cycle self-sufficiency"29 and its domestic articulation in purely technological, rather than security, terms after the 1979 Revolution indicates a different Iranian nuclear identity dismissive of the notion of technological determinism. Iranian Supreme Leader Ayatollah Ali Khamenei's August 2005 fatwa (religious edict) categorically forbidding procurement, development, stockpiling, and use of nuclear weapons, while underscoring the merits and virtues of a civilian program, can be analyzed within this context as well.

\section{Psychological Context}

According to this paradigm, due to their revolutionary and extraordinary nature and extreme rarity, proliferation decisions belong to a category of foreign policy decision-making (FPDM) that is, at least partially, extricable from the geostrategic context of the state's international emplacement. Bomb decisions, in this reading, require "an extraordinary effort of will" reflective of "the psychology of the leaders who make them." From this perspective, "there are discrete decision-making pathways leading from different national identity conceptions, through emotions, to ultimate nuclear choices." ${ }^{30}$ Focusing the analysis on the "psycho-milieu" of the ultimate decision makers, these cognitive behavioralist works aim to distill nuclear decisions into the idiosyncratic actorlevel interaction between the decision makers and the broader socio-institutional context surrounding and shaping them. The agency factor in the form of each state's unique nuclear psychology figures prominently in these conceptual frameworks where decisions

\footnotetext{
${ }^{29}$ Seyyed Hossein Mousavian, Protokole Elhaghi va Rahborde Jomhourye Eslamye Iran (The Additional Protocol and The Islamic Republic of Iran's Strategy)) (Tehran: Expediency Council Strategic Research Center, 2007).

${ }^{30}$ Jacques E. C. Hymans, The Psychology of Nuclear Proliferation: Identity, Emotions and Foreign Policy (Cambridge: Cambridge University Press, 2006). Italics added.
} 
are not structurally imposed through the state's emplacement in the international system, but agentially actualized by the decision-makers. ${ }^{31}$

A cursory survey of the INP literature reveals two distinctive pathways taken on the application of the psychological paradigm to Iran's nuclear enterprise: A Persian narrative and an Islamic Republic rendition. Proponents of the Persian narrative subscribe to a secular civilizational/national reading of the INP. In this view, Iran's nuclear program is a prestige exercise reflecting the nation's glorious past and aimed at rediscovering and resurrecting its "rightful place" among the community of nations. Thus conceptualized, Iran's nuclear ambitions emanate --self-referentially, as it were-- from its long-standing national and civilizational consciousness and the 1979 Islamic Revolution hardly constitutes an inflection point in Tehran's nuclear-thinking curve. In this view, Iran's nuclear interests are not susceptible to the ebb and flow of Iranian politics since they belong to a uniquely Persian "level of analysis" with its own codes and modes of decision and action that superimposes itself on the idiosyncrasies of decision makers. Ardeshir Zahedi, the foreign minister who signed the NPT in 1968 on behalf of Iran, and Akbar Etemad, the founder and first president of the AEOI, are among the most prominent figures who see the INP in this secular national light. ${ }^{32}$

The second is the "Mad Mullahs" strand of thought that takes a religiously imbued approach toward the INP. From this perspective, the 1979 Islamic Revolution marks a genuine change of heart on the part of the Iranian state in terms of its strategic

\footnotetext{
${ }^{31}$ For a brief review of this theoretical framework, see Valerie Hudson, Foreign Policy Analysis: Classic and Contemporary Theory (Lanham, Maryland: Rowman \& Littlefield Publishers, 2006).

${ }^{32}$ Ardeshir Zahedi, interview by Bijan Farhoudi, IRAN US Relations- Ambassador Ardeshir Zahedi's Historical Perspective, Voice of America (VOA), 2006. Akbar Etemad, Barnameh-ye enerji-ye atomi-ye iran, talash-ha va tanesh-ha (Iran's Nuclear Energy Program, Hopes and Challenges), ed. Gholam Reza Afkhami (Bethesda, MD: Bonyad-e Motale'at-e Iran (Foundation for Iranisn Studies), 1997).
} 
destiny. In this reading, Tehran's nuclear efforts after the Revolution cannot be decontextualized from the broader Shi'a Islamic themes that were politically embodied and actualized in the Islamic Republic. This is a cosmically laced interpretation of Tehran's nuclear consciousness and socialization whose proponents in the West see "nuclear ayathollahs" --in an international system securitized toward religion in general and especially antagonistic toward Islam-as an ominous harbinger for the future of international peace and stability.

Advocates of this cosmic rendition of the INP conclude that Iran's hermetically sealed clerical establishment is not only reckless and fatalistic in its security speech-acts (e.g. their attitude toward Israel and the Satanic Verses controversy) but also radically insensitive to secular mechanisms of dissuasion and persuasion. These qualities make the Iranian state all but impervious to the otherwise sobering effects of "nuclear endowment," hence rendering the Islamic Republic an unqualified candidate to be educated into the secular doctrine of nuclear deterrence. ${ }^{33}$ Based on this reading Iran's apocalyptically offensive interests have already been conclusively and irreversibly established and its rock-bottom intentions are static and unimpressionable.

With this theoretically informed review of the literature on proliferation and the INP at hand, I will now turn to the present work's perspective on how best to draw upon these models in exploring Iran's nuclear behavior and teasing out its atomic interests. Before that, though, an important caveat is in order: The foregoing theoretical categories are not, by any means, mutually exclusive and substantial overlaps are observable among them. As a matter of fact, in an effort to bridge the psychological and geostrategic

\footnotetext{
${ }^{33}$ For an extreme case, see Norman Podhoretz, World War IV: The Long Struggle Against Islamofascism (New York: Doubleday, 2007).
} 
contexts of proliferation, a number of works on Iran's nuclear thinking have traversed the boundaries between these two paradigms. ${ }^{34}$

Although these analyses tend to be more broadly based as they have a longer temporal horizon in sight and are more inclusive in their treatment of attention-worthy developments, the generic problem of framework-intensive historical explanations persists here too. From this perspective, as the explanatory model grows hegemonic it dictates the inclusion, exclusion, and truncation of historical evidence and, subsequently, the flow and direction of analysis. The latter is the unfortunate state of the bulk of academic and policy scholarship on the INP where the analytical narrative plays second fiddle to the theoretical or policy template.

Such a reversal of roles produces a number of pathologies: For one thing, it creates "motivated reasoning" and emasculates the narrative's ability to re-generate or transform itself from within as new and contradictory information become available. In this situation, framework-defying data are either not acknowledged or discounted or altogether discarded. ${ }^{35}$ For another, it gives rise to cognitive rigidities that limit the counter-proliferation decision maker's capacity to devise imaginative policy solutions. The need for such imaginative and breakthrough thought patterns is becoming increasingly imperative as Iran's nuclear standoff with the West is deadlocking as it is inching toward its second decade. ${ }^{36}$

\footnotetext{
${ }^{34}$ A notable example is Shahram Chubin, Iran's Nuclear Ambitions (Washington, D.C.: Carnegie Endowment for International Peace, 2006).

${ }^{35}$ Robert Jervis, Perception and Misperception in International Politics (Princeton, NJ: Princeton University Press, 1976).

${ }^{36}$ Ray Takeyh, Hidden Iran: Paradox and Power in the Islamic Republic (New York: Times Books, 2006).
} 


\section{Conceptual \& Methodological Framework}

As suggested above, the most intractable challenge to combining a theoryconscious and historically rich analysis on the INP is maintaining a dialogical and constantly interacting balance between receptivity to time-sensitive and evolving political, technological, and military processes (on both domestic and international levels) on the one hand and structural nuclear intentions, interests, and inertias on the other. Such a balance could only be struck successfully by utilizing a history-intensive (as opposed to framework-intensive) and discourse-rich strategy that tracks the evolutionary trajectory of the phenomenon under study along a unifying theme.

The present work endeavors to conduct one such intimate diachronic engagement with the INP by adopting an "analytical process-tracing narrative." This narrative, in turn, will organically and incrementally generate a "conceptual framework" along the unifying theme and guiding post of securitization.

Analytical process-tracing, as Alexander George and Andrew Bennett explicate it, is a powerful tool in extrapolating a case study's "explanation into a generalization." ${ }^{\text {"37 }}$ In other words, in analytical process-tracing an otherwise atheoretical narrative presented "in the form of a chronicle that purports to throw light on how an event came about" is embedded into "an analytical causal explanation couched in explicit theoretical terms.",38 Such an analytical historical narrative, as applied to the INP, is bound to involve complex and non-linear patterns of causality and correlation due to the infinitely complex trajectory along which Iran's nuclear socialization has evolved.

\footnotetext{
${ }^{37}$ Andrew Bennett Alexander L. George, Case Studies and Theory Development in the Social Sciences (Cambridge, MA: The MIT Press, 2005).

${ }^{38}$ Ibid. 211.
} 
In order to give cogency, clarity, and directionality to such a labyrinthine phenomenon as the INP, it is imperative to define a powerful organizing theme around which all relevant events, persons, and processes could find their proper context and implications. In other words, the function of this organizing theme is to decide what events, decision-makers, and historical junctures have been instrumental in terms of their nuclear proliferation relevance in Iran's half-century long atomic journey.

Deciding on securitization ${ }^{39}$ as the organizing theme to historicize the INP is not an abstract or arbitrary or, for that matter, a compromise choice. Quite the contrary, one could easily argue that the INP's security designation defines, implicitly or explicitly, the ultimate fault line along which the whole array of INP actors and events are deployed and demarcated. This reality will obtain unless a comprehensive international desecuritization of the INP takes place through regime change or a drastic change of heart in Tehran, a relatively unlikely scenario in the foreseeable future.

From this perspective, Iran's nuclear story can be narrated as the unfolding of constant interaction between domestic and international forces of "nuclear securitization" and "nuclear de-securitization." Within this framework, INP securitizers are state and non-state actors whose threat judgments have national and/or international security implications in that they noticeably politicize, securitize, and militarize Iran's nuclear bid. The threat-designation implications of these judgments could be immediate or delayed,

\footnotetext{
${ }^{39}$ Securitization, as employed in this work, is a "self-referential" discursive practice (securitizing move) through which a phenomenon (the INP in this case) is presented and designated as a "proliferation threat." A successfully securitized referent object - i.e., a phenomenon accepted by a critical mass audience as an existential threat through a mix of coercion and consent measures - acquires sufficient "resonance for a platform to be made from which it is possible to legitimize emergency measures" to address it. The "rhetoric of existential threat" is a arguably the most critical step in the securitization process whereby an issue is lifted above "normal politics." For a comprehensive analysis of securitization, see Ole Waever, Jaap de Wilde \& Barry Buzan, Security: A New Framework for Analysis (Boulder, CO: Lynne Rienner Publishers, 1998).
} 
implicit or explicit, direct or by association. These individual, institutional, and state securitizing actors are present in the domestic and international context of the INP and collectively pull the INP toward securitization and, ultimately, militarization. In what follows, I will try and sketch out a template of who these securitizing and de-securitizing actors are and how their roles have evolved:

At the international state level, especially after the 1979 Revolution, the United States, independently or in conjunction with Israel, has been the INP's core strategic (hyper)-securitizer. The international de-securitizing force counterbalancing the United States has come, on and off, from the Russian Federation and China. The latter force has been inconsistent, trepidatious, reluctant, at times tactically driven and hence malleable and vulnerable in the face of the INP's more institutionalized and momentous securitizing forces in the post-Revolution era. The European Union-- especially Germany, Great Britain, and France (the so-called EU3)-- has had a swing role in the international securitization and de-securitization of the INP. The thrust of the EU's posture toward the INP in general, though, has been toward bandwagoning with the United States either under the structural pressure of the Cold War in the Shah era or fear of marginalization in a unipolar post-Cold War world in the Islamic Republic era.

Since the general securitization pattern of the INP has been toward further internationalization, one can observe a proliferation of state actors with alternating securitizing and/or de-securitizing functions. The newest arrivals on the scene, at this writing, are Brazil and Turkey both of which are currently playing a cautious desecuritizing role. The present work will place special emphasis on tracking the trajectory 
of asymmetrical interaction between securitizing and de-securitizing forces of the INP at the international level with a special emphasis on the United States' predominant role.

At the international institutional level, the United Nations Security Council (UNSC) is the most consequential securitizer of the INP. The UNSC has been actively exercising this securitizing role through an incrementally tightening sanctions policy since the referral to the United Nations of Iran by the IAEA in July 2006. The counterbalancing institutional de-securitizing forces are the Shanghai Cooperation Organization (SCO), the Non-Aligned Movement (NAM), and the Organization of Islamic Conference (OIC). The IAEA has oscillated between securitizing and desecuritizing the INP, although since the referral of Iran to the UNSC, its de-securitization competence has grown substantially degraded at the expense of its more pronounced securitizing functions. The dominant argument in Tehran after the 2002 nuclear revelations has been that the IAEA actually triggered the institutional securitization of the INP by stepping beyond its technical and legal job description and by politicizing the issue of Iran's nuclear fuel cycle, otherwise an issue of pure technicality.

De-securitizing forces at the individual and bureaucratic levels have historically dominated the domestic scene of Iran's nuclear program. At the national level, the Shah and the Supreme Leader have performed the function by consistently privatizing the decision-making process on the INP and de-linking it from any military contingencies. Some signs of the securitization of the INP before 1979 are traceable in Khomeini's critiques of the Shah's ambitious nuclear program, although whether these pronouncements had any tangible securitizing resonance and traction is open to retrospective speculation. After the Revolution no consequential individual-level actor on 
Iran's domestic political scene has securitized the INP. This situation almost changed though, when the fallout of the 2009 Iranian presidential election gave rise to a highly organized opposition movement whose leadership floated the idea of redefining the INP in factional, as opposed to national, terms. ${ }^{40}$ At the domestic bureaucratic level, a securitizing entity has always been absent from the scene. The de-securitization forces at this level are bureaucratically represented by the AEOI whose leadership has traditionally tended to transcend the ebb and flow of Iranian politics.

Between the above-mentioned domestic and international levels, there are a number of important non-state network actors whose relevance for the securitization of the INP became more visible after the $9 / 11$ terrorist attacks and within the broader context of the Global War on Terror (GWoT), securitization of Islam in international politics, and the doomsday menace of nuclear terrorism. ${ }^{41}$ These are actors that confer on the INP urgent international security implications that wouldn't otherwise attend Iran's nuclear behavior even as a theocratic revisionist state. The Mujahedin-e Khalq Organization (MKO or MEK), without doubt, resides at the securitization extreme of this network level of analysis.

The INP elite constitutes the last group of actors influential in making historical security sense of Iran's nuclear drive. INP elite actors are domestic and international individuals with political visibility and scientific, bureaucratic, legal, or security credentials whose pronouncements on the INP have significant impact on the

\footnotetext{
${ }^{40}$ So far, Mir Hossein Mousavi as the plausible leader of the so-called Greens has shown no sign of inching towards securitizing the INP, a position prone to change if centralization of power in Iran grows excessively exclusionary and the Reformist camp is completely and irretrievably shut out of the power structure.

${ }^{41}$ Graham Allison, Nuclear Terrorism: The Ultimate Preventable Catastrophe (New York, NY: Holt Paperbacks, 2005).
} 
atmospherics and dynamics of its securitization. These actors' function and significance is most conspicuous in pronouncements of the INP's "epistemic community" on domestic or international levels. The non-state character of INP elite actors renders their scientific, political, bureaucratic, legal, military, religious, or environmental judgments on Iran's nuclear bid objective and hence influential in accelerating or decelerating INP's securitization drift. For example retired general John Abizaid's iconoclastic remarks in September 2007 on the possibility of living with a nuclear-armed Iran had a tremendous impact in slowing down the hyper-securitization of INP in the U.S. national security community. ${ }^{42}$ Such also was the case with Thomas Schelling and Kenneth Waltz's sentiments regarding the deterrability of a nuclear Iran.

To conclude, these six:

1-International state,

2-International institutional,

3-Network,

4-Domestic bureaucratic, and

5-Domestic institutional

6-Nuclear elite

layers of analysis constitute the broad organizing layers of the present work. Each of these layers has a securitization and de-securitization extreme with a gray middle area along which the so-called "swing players" operate.

\footnotetext{
${ }^{42}$ John Abizaid, Retired general: U.S. can live with a nuclear Iran, September 18, 2007, http://edition.cnn.com/2007/WORLD/europe/09/18/france.iran/index.html (accessed January 15, 2010).
} 


\section{International State Level}

De-securitization

Securitization/Militarization

$\leftarrow$

Cuba/Venezuela Pakistan Turkey Brazil Russia/ China Persian Gulf Arab States US Israel

II. International Institutional Level

De-securitization

Securitization/Militarization

$\leftarrow$

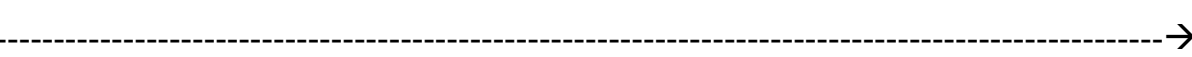

SCO NAM OIC

IAEA

UNSC

\section{Network Level}

De-securitization

Securitization/Militarization

$\leftarrow$ $\rightarrow$

IV. Domestic Individual Level

De-securitization

Securitization/Militarization

$\leftarrow$

Mousavi (After June 2009?)

Khomeini (Before 1979)

\section{Domestic Bureaucratic Level}

De-securitization

Securitization/Militarization

$\leftarrow$ 
VI. Elite Level

De-securitization

Securitization/Militarization

$\leftarrow$

Tracking the crisscrossing interaction between these different securitizing and desecuritizing actors in a historical context constitutes the central task of this project. A careful tracing of security-relevant events on these levels will reveal the broad contours of the evolutionary trajectory of the INP and its future path(s). Out of this theoretically conscious historical narrative, one can make educated observations about the overall thrust of the INP along the securitization-desecuritization continuum.

\begin{tabular}{|l} 
I. Securitization Continuum \\
(Technological/Legal) Non-politicized Politicization $\quad$ Securitization
\end{tabular}

Within this framework, if international forces of securitization get the upper hand (possibly further energized by the de-nationalization of the INP on the domestic scene) complete nuclear securitization and even militarization of the INP would become a distinct possibility. A rough analogy of this analogy would be the militarization of the Iraqi WMD program that culminated in the Operation Iraqi Freedom of March 2003. This scenario gains more plausibility and reinforcement by the triangulation of the Iran-nukes nexus with international terrorism following 9/11, placement of Iran on the so-called 
"axis of evil" by the Bush administration and their atmospheric impact on how the INP was contextualized afterwards.

On the other hand, if de-securitizing agents of the INP coalesce into a consequential coherent force with international credibility, directionality and visibility (an unlikely scenario under the circumstances) or if the United States' ability to sustain the INP at the top of international security discourse fizzles out in the face of more urgent and intractable domestic and international concerns like the Arab Spring and the Financial Crisis, the Iranian nuclear program could be re-prioritized as a technical/legal proliferation challenge rather than an urgent existential security dilemma. 


\section{CHAPTER 2}

\section{7-1973: NUCLEAR INFANCY}

This era marks Iran's first exposure to, raw fascination with, and unsophisticated socialization into the nuclear world. President Eisenhower's 1953 Atoms for Peace Program rolled out the introduction of a host of Third World countries into the nuclear age. Iran was no exception to this unfolding trend as the enervated country was trying to find its self-confidence and define its regional and international role following the strategically bruising experiences of the Anglo-Soviet invasion of August 1941, the Soviet tardiness to leave Iran's Azerbaijan Province in 1946, and the CIA orchestrated coup of 1953 that toppled democratically elected Prime Minister Mohammad Mosaddeq.

The 14 July Revolution (1958) in Iraq and Brigadier General Abdul Karim Qasim's subsequent withdrawal from the Baghdad Pact were also instrumental in rendering the young Shah sensitive to Iran's external vulnerabilities through indirect Communist subversion. Viewed from a strategic perspective, 1958 was the beginning of a securitized era in Iran's relations with its Arab neighbor to the west. This securitized atmosphere was additionally reinforced by the Shah's rather disproportionate alarmism at the Soviet threat from the north and Moscow's courting of Tehran's Arab rivals and adversaries in the Middle East and North Africa.

During this founding period Iran was gradually coming to conceptual grips with the notion of the atom and its hardware and software implications. Lacking a sophisticated conceptual framework (either domestically generated or externally granted to or imposed on it) to help cultivate and calibrate its nuclear identity, Tehran lacked the scientific, bureaucratic, and infrastructural foundations commensurate for a solid national 
nuclear enterprise. This was in contrast, for instance, to India's nuclear journey where the Atomic Energy Research Committee was founded by the government in 1946 (prior to the country's independence) with a prominent nuclear physicist Homi J. Bhabha as its chairman.

In 1957, the Council of Ministers also established the National Iranian Atomic Energy Commission (IAEC). The body was headed by the Prime Minister with the Minister of Industry and Mines acting as his deputy. The IAEC was predominantly a policy-formulating organization whose role in conceptualizing and streamlining Iran's nuclear efforts was only of symbolic significance.

In Iran, the Shah virtually embodied and encapsulated the country's dabbling with the atom in this period and almost single-handedly gave visibility, texture, and directionality to it. As a matter of fact, the whole nuclear enterprise in this period amounted to little more than an exercise in crafting the sorely needed prestige factor for the person of the Shah following his humiliating escape in 1953 and his re-accession to the throne in a foreign orchestrated coup d'état, events that ingrained his image as a U.S. client figure for the decades to come.

The available archival evidence does not shed a definitive light on the initial epiphany moment of the Shah's nuclear fascination or its subsequent evolution into a full-fledged obsession toward the mid 1970s. Having said that, one person has credited himself explicitly with having been the inspirational figure behind the Shah's nuclear initiation. Abolfath Mahvi, the Shah's cousin whose name as the owner of the consulting firm, Iran Nuclear Energy Co. (INECO), appears sporadically in U.S. documents, relates a story where he asks His Imperial Majesty (HIM) during his 1963 visit to the USA: 
"since the U.S. President will not support your request for America to increase its purchase of Iranian oil that would, in return, allow you to purchase more arms, why not consider acquiring nuclear weapons? It will reduce the need to purchase more sophisticated arms and military hardware and will add to Iran's prestige among the international community." Mahvi claims this conversation made a profound and lasting impression on the Shah and how he came to approach to the question of the atom. Many have, however, come to dispute and refute this claim of Mahvi's in subsequent years. The foundational figure of Iran's nuclear program Akbar Etemad finds Mahvi's claims disingenuous at worst and hyperbolic at best calling him a run-of-the-mill influence peddler who, riding on the Shah's coattails, made a fortune on secret commissions and not-so-secret kickbacks. Etemad, on the other hand, believes that the Shah's riveted nuclear fascination had as much to do with HIM's principal conviction that "oil was too precious to be burned up" as with anything else. ${ }^{43}$ In any event, a balanced reading of the available archival evidence does not even circumstantially suggest that the Shah's nuclear consciousness was, as Mahvi claims, born with an eye on the atom's national security dividends. This is in sharp contrast to the Islamic Republic's war-borne nuclear awakening that has rendered a de-securitized narrative of the INP a hard sell to this date.

Based on a well-rounded reading of the available evidence, the trigger on the Iranian side to enter the nuclear world seems to have come from the Shah's personal interest in the issue and embassy reports on nuclear cooperation between the United

\footnotetext{
${ }^{43}$ Akbar Etemad, interview by Sergei Barseghian, Nagofteh-haye Akbar Etemad, Pishgam-e Fan Avari-ye Hasteh-i ye Iran (The Untold Story of Akbar Etemad, The Pioneer of Iran's Nuclear Technology), Etemad Melli (9 April, 2008). Abolfath Mahvi, 40-year-old Dream How Iran's Muclear Program was Born, January 6, 2009, http://www.iranian.com/main/2009/jan/40-year-old-dream (accessed July 14, 2010).
} 
States and other Third World countries within the Atoms for Peace Program. ${ }^{44}$ For example, on January 12, 1955 Ali Asghar Hekmat, the Iranian ambassador to New Delhi informed the Iranian Ministry of Foreign Affairs of Indian and Pakistani nuclear efforts. Hekmat specified the conference India had organized on various aspects of nuclear technology and emphasized the personal interest Jawahar Lal Nehru had taken in developing a nuclear infrastructure. ${ }^{45}$ Hekmat also mentioned a trip by a US delegation to India to explore avenues for nuclear cooperation between the two countries. ${ }^{46} \mathrm{He}$ recommended officials in Iran follow India's suit and start exploring various aspects of nuclear technology as well. ${ }^{47}$

In 1956, the Iranian Ministry of Foreign Affairs published a report in which it referred to a cable by the Iranian embassy in Amman, Jordan on the nuclear cooperation between the US and Israel and arrangements to establish a nuclear science lab. According to the report, this nuclear facility would enable Israel to make practical headway in the nuclear field. The document also alluded to similar arrangements in place between the US

\footnotetext{
${ }^{44}$ The archival record does not shed light on whether the Shah's nuclear appetite was whetted or otherwise influenced by the intelligence on Israel nuclear activities starting in 1947 followed by Egypt's nuclear efforts under Nasser in the mid-1950s. Assad Homayoun believes that Iran at the time did not possess the capability or the curiosity to gather intelligence on either party's nuclear programs. Assad Homayoun, interview by Mohamad Homayounvash. Washington D.C. (2010, 23-July).

${ }^{45}$ This seems to be referring to the Conference on the Development of Atomic Energy for Peaceful Purposes held in New Delhi on November $26^{\text {th }} \& 27^{\text {th }}, 1954$ and inaugurated by Prime Minister Nehru.

${ }^{46}$ This seems to be when members of the US Joint Committee on Atomic Energy visited India to promote the expansion of peaceful applications of atomic energy. This meeting paved the way for an Indo-US agreement under which the United States agrees to supply India with heavy water to moderate the planned Canada-India Reactor, also known as the Canada-India Reactor, U.S., or CIRU.S. (Roberta Wohlstetter, "The Buddha Smiles:" Absent-Minded Peaceful Aid and the Indian Bomb (Los Angeles: Pan Heuristics, 1977)

${ }^{47}$ Erfan Karimi, Barresi Syast-ha-ye Doganeh-ye Hasteh-i-ye Amrika dar Iran Qabl va Pas az Enqelab (A Review of the United States' Double-standard Nuclear Policy toward Iran Before and After the Revolution, April 10, 2010, http://strategicreview.org/?p=14096 (accessed July 25, 2010).
} 
and Lebanon. ${ }^{48}$ Impressed by the report, Iranian Prime Minister Hossein Ala inquired why was it that the Iranian Government had not rolled out similar negotiations with the United States. $^{49}$

Following up on the Prime Minister's keen interest in the issue, Tehran University Chancellor Manoucher Eqbal started negotiations with Loy Henderson the former US ambassador to Iran (1951-1954) and the director of the Office of Near Eastern Affairs in the U.S. State Department. Looking favorably upon the issue, Henderson pledged to take up the issue with the relevant American officials. Following Eqbal's negotiations with Henderson, the Iranian Ministry of Foreign Affairs started a series of preliminary talks with the US embassy in Tehran. Even at its most exploratory and tentative stages the nuclear issue was not a purely technical matter devoid of political overtones as far as Washington was concerned. For instance, in November of 1955 Washington sought the advice of the US embassy in Tehran regarding the favorability of the over-all political situation for sending a physicist to Tehran to conduct informal negotiations to initiate a nuclear research program in Iran. ${ }^{50}$

As Iran's efforts to dip its toes into the nuclear world were assuming higher priority, on July 18, 1956, in a letter to US Secretary of State John Foster Dulles, Iranian Ambassador to Washington Ali Amini (who went on to become Prime Minister in 1961)

\footnotetext{
${ }^{48}$ Erfan Karimi, Barresi Syast-haye Dogane-ye Hasteh-i Amrika dar Iran Qabl va Pas az Enqelab (A Review of the United States' Double-standard Nuclear Policy toward Iran Before and After the Revolution, April 10, 2010, http://strategicreview.org/?p=14096 (accessed July 25, 2010).

${ }^{49}$ Quoted in Ibid.

${ }^{50}$ Confidential. Office Memorandum. United States Government. Reply to Tehran's 770, November 14, November 22, 1955. RG 59 General Records of the Department of State Office of the Secretary Special Assistance to Secretary of State for Atomic Energy and Outer Space General Records Relating to Atomic Energy Matters, 1948-1962 Box 500. National Archives at College Park, College Park, MD.
} 
"communicated to His Excellency the desire of the Iranian Government to enter into negotiations looking toward the conclusion of an intergovernmental agreement for cooperation in matters concerning the civil uses of atomic energy." ${ }^{, 51}$ On July 27 , the United States responded affirmatively to the Iranian request and on August 16, 1956, the United States government presented a draft agreement to the representatives of the Iranian embassy in Washington. The draft was subsequently sent to a "Scientific Committee of the University of Tehran" for review. ${ }^{52}$

The draft agreement proposed by the United States followed the same guidelines in place in agreements concluded "with 32 other countries." The main pillars of these guidelines were "A) exchange of unclassified technology; B) lease of up to 6 kilograms of U-235 for reactor fuel, as well as laboratory quantities of other special materials; and C) Appropriate safeguards." 53

Iran's main impediment, as far as the Americans could diagnose, in the way of getting the ball rolling on a pilot-scale nuclear program was a virtual lack of trained personnel in the country. Asked about "the nature of research facilities and trained physicists in Iran, during a 1956 visit to the United States, an Iranian delegate to the

\footnotetext{
${ }^{51}$ Letter from the Imperial Iranian Embassy, Washington DC to U.S. Secretary of State, John Foster Dulles, July 18, 1956. RG 59 General Records of the Department of State Office of the Secretary Special Assistance to Secretary of State for Atomic Energy and Outer Space General Records Relating to Atomic Energy Matters, 1948-1962 Box 500. National Archives at College Park, College Park, MD.

${ }^{52}$ Memorandum, October 11, 1956 Meeting with Professor Bazorgan Regarding Implementation of Iran Bilateral. RG 59 General Records of the Department of State Office of the Secretary Special Assistance to Secretary of State for Atomic Energy and Outer Space General Records Relating to Atomic Energy Matters, 1948-1962 Box 500. National Archives at College Park, College Park, MD.

${ }^{53}$ Memorandum for the Under Secretary, Department of State. Special Assistant to the Secretary. Request for Circular 175 Authorization to Sign Atomic Research Reactor Agreement with Iran. October 30, 1956. RG 59 General Records of the Department of State Office of the Secretary Special Assistance to Secretary of State for Atomic Energy and Outer Space General Records Relating to Atomic Energy Matters, 19481962 Box 500. National Archives at College Park, College Park, MD.
} 
IAEA replied, "there are about 40 full professors on the faculty of science at the University of Tehran."

During his visit to the U.S., the Iranian delegate tried to contextualize Tehran's nuclear quest in a broader setting citing the "political pressure, supported by popular demand, which had descended upon the Government and thence the faculty of science, to develop atomic energy for Iran." Rather interestingly, the Iranian delegate was adamant that it was "imperative" for him to "return to Iran with the necessary information prerequisite to initiating a reactor project." During the meeting, the Americans suggested that considering its lack of trained personnel Tehran opt for the swimming pool type reactor, as the water boiler type (the first reactor the Japanese had decided on and Iran had an eye on) would require an "ample cadre of trained technicians". ${ }^{54}$

Following the delegate's report to Tehran, in October 1956 the Iranians, through the embassy in DC, signaled their willingness to sign the agreement as proposed by the US. The Shah, right from the get-go, took a personal interest in the issue expressing his desire to personally announce the agreement "on the occasion of the opening of a US Atoms-for-Peace Exhibit" in Tehran. ${ }^{55}$ On November 1, 1956, the Atomic Energy Commission (AEC) recommended to the President the approval of the Agreement negotiated jointly by the Atomic Energy Commission and the Department of State in

\footnotetext{
${ }^{54}$ Memorandum, October 11, 1956 Meeting with Professor Bazorgan Regarding Implementation of Iran Bilateral. RG 59 General Records of the Department of State Office of the Secretary Special Assistance to Secretary of State for Atomic Energy and Outer Space General Records Relating to Atomic Energy Matters, 1948-1962 Box 500. National Archives at College Park, College Park, MD.

${ }^{55}$ Memorandum for John A. Hall, Atomic Energy Commission. Iranian Desire to Conclude Research Reactor Bilateral October 31, 1956. RG 59 General Records of the Department of State Office of the Secretary Special Assistance to Secretary of State for Atomic Energy and Outer Space General Records Relating to Atomic Energy Matters, 1948-1962 Box 500. National Archives at College Park, College Park, MD.
} 
keeping with the Atomic Energy Act of 1954. The AEC considered the agreement "an important and desirable step in advancing the development of the peaceful uses of atomic energy in Iran" through "cooperation between the two countries with respect to the design, construction and operation of research reactors." ${ }^{56}$ Thereupon, having made the determination that it "would not constitute an unreasonable risk to the common defense and security," President Eisenhower authorized the execution of the agreement in a letter dated December 22, 1956 sent to the AEC. ${ }^{57}$

The agreement was finally signed at 2:30 p.m., on March 5, 1957 by Dr. Ali Amini, the Iranian Ambassador to the United States, Lewis Strauss, Chairman of the AEC, and William M. Rountree, Assistant Secretary of State. The signing was formally announced by the Shah at the opening ceremony of the US Atoms-for-Peace exhibit in Tehran on March 6, 1957. ${ }^{58}$ Almost two years later, in a February 4, 1959 letter to the AEC, the Iranian Embassy in Washington D.C. informed the Americans of the ratification of the Agreement by both houses of the Iranian Parliament. ${ }^{59}$ Thereupon, the

\footnotetext{
${ }^{56}$ United States Atomic Energy Commission, Agreement for Cooperation with the Government of Iran December 6, 1956. RG 59 General Records of the Department of State Office of the Secretary Special Assistance to Secretary of State for Atomic Energy and Outer Space General Records Relating to Atomic Energy Matters, 1948-1962 Box 500. National Archives at College Park, College Park, MD.

${ }^{57}$ Letter from Atomic Energy Commission to Carl Durham, Chairman of the Joint Congressional Committee on Atomic Energy, Washington D.C. March 13, 1957. RG 59 General Records of the Department of State Office of the Secretary Special Assistance to Secretary of State for Atomic Energy and Outer Space General Records Relating to Atomic Energy Matters, 1948-1962 Box 500. National Archives at College Park, College Park, MD.

${ }^{58}$ For the Press. United States Department of State. United States Atomic Energy Commission. "Atoms for Peace" Agreement Signed by Iran and United States. March 6, 1956. RG 59 General Records of the Department of State Office of the Secretary Special Assistance to Secretary of State for Atomic Energy and Outer Space General Records Relating to Atomic Energy Matters, 1948-1962 Box 500. National Archives at College Park, College Park, MD.

${ }^{59}$ From Ali Gholi Ardalan, Ambassador of Iran to the United States to Mr. Clark C. Vogel Acting Director Division of International Affairs Atomic Energy Commission Washington D.C. February 4, 1959. RG 59

General Records of the Department of State Office of the Secretary Special Assistance to Secretary of State
} 
U.S. Government notified the Iranians of entry into force of the Agreement on April 27, $1959 .{ }^{60}$ Coming on the heels of the 1955 "Treaty of Amity and Economic Relations and Consular Rights" between Iran and the United States, the 1957 nuclear treaty was signed in an atmosphere of comity between the two countries and was of tremendous prestige value to Tehran.

The press released to the media on the occasion of the signing of the treaty by the Department of State and the Atomic Energy Commission contained a lot of futurelooking sentiments on the potential for Iran and the United States to work in the nuclear field. Chief among them was expression of "hope and expectation" that the initial agreement would lead to "consideration of further cooperation at some future date of an agreement in the field of nuclear power," an ambition that proved more elusive than the Americans and Iranians expected as the geopolitical terrain in the Middle East and the Indian Subcontinent underwent some tectonic shifts with massive implications for securitization of national nuclear programs as we will see in the next chapter.

The 1957 agreement also expressed optimism that it would "enable the Iranians to enhance their own country's training and experience in nuclear science and engineering for the development of peaceful uses of atomic energy within the framework of the ‘Atoms-for-Peace Program.” Mention was also made of the Iranian enrollees "attending the reactor technology courses at the International School for Nuclear Science and Engineering operated for the U.S. Atomic Energy Commission by the Argonne National

for Atomic Energy and Outer Space General Records Relating to Atomic Energy Matters, 1948-1962 Box 500. National Archives at College Park, College Park, MD.

${ }^{60}$ Note handed to Dr. Parviz Mahdavi, Counselor. Iranian Embassy. April 27, 1959. RG 59 General Records of the Department of State Office of the Secretary Special Assistance to Secretary of State for Atomic Energy and Outer Space General Records Relating to Atomic Energy Matters, 1948-1962 Box 500. National Archives at College Park, College Park, MD. 
Laboratory in cooperation with Pennsylvania State University and North Carolina State College."

Iran's 1957 nuclear agreement with the United States should also be situated within the broader context of the Baghdad Pact, a loose alliance modeled after NATO and concluded (under US promise of military and economic aid) between Iran, Iraq, Turkey, Pakistan, and Great Britain in 1955 to fend off Soviet infiltration into the Middle East. As the United States and Great Britain deemed the pact membership an appropriate platform to get the Middle East started on the Atoms for Peace Program, on March 31, 1957 Iraq's King Feisal II formally inaugurated the Baghdad Pact Nuclear Training Centre in Baghdad's Salchiyah district. The center was conceived to provide training in "nuclear physics, radiochemistry, electronics, medical applications, and agriculture" to the scientific community of the Pact member states and other countries in the Middle East.

The general assessment of the possible power-generating applications of nuclear power at the time was that: "The application of nuclear power will not be worthwhile in Iraq and Turkey in the foreseeable future, owing to the abundant supply of oil and hydro power. Iran and Pakistan are, however, interested in the potentialities of nuclear power units of medium output for some areas, and the Centre will help by advice to promote this development." Britain assumed an advising and supervisory role in the enterprise. ${ }^{62}$ Within this context Iran was also singled out as one of the countries in the Asian-African

\footnotetext{
${ }^{61}$ For the Press. United States Department of State. United States Atomic Energy Commission. "Atoms for Peace" Agreement Signed by Iran and United States. March 6, 1956. RG 59 General Records of the Department of State Office of the Secretary Special Assistance to Secretary of State for Atomic Energy and Outer Space General Records Relating to Atomic Energy Matters, 1948-1962 Box 500. National Archives at College Park, College Park, MD.

62 John Cockcroft, "The Baghdad Pact Nuclear Training Centre," Nature 179, no. 4567 (1957): 936.
} 
area with strong interest in the economics of nuclear power in a 1957 hearing before the "Joint Committee on Atomic Energy" in the U.S. Congress. ${ }^{63}$

According to a report published in the Bulletin of the Atomic Scientists, the Baghdad Pact Nuclear Training Centre would also offer "post-graduate work in radioactive isotopes" and include "facilities (electronic and radiochemical) to train 20 students" with Sir John Cockcroft as the chairman of the Center's council. ${ }^{64}$ The Center posted a fairly successful track record over its short lifespan training about sixty nuclear scientists from the Pact member states before the 1958 Iraqi Revolution terminated its activities. $^{65}$

Following the 14 July coup in Baghdad during which the anglophile King Faisal was swept from power, Iraq drifted toward the Soviet orbit and withdrew from the Baghdad Pact. Consequently, as per the decision to re-establish the Baghdad Pact Nuclear Centre in Tehran taken jointly by the CENTO countries in January $1959^{66}$, the CENTO Institute of Nuclear Science officially replaced the Bagdad Pact Nuclear Center, its headquarters moved to Iran and was officially inaugurated by the Shah in Tehran University's newly built Faculty of Science building. ${ }^{67}$ One could mark the occasion as an embryonic sign of His Imperial Majesty's operational interest in the atom.

\footnotetext{
${ }^{63}$ Hearings before the Joint Committee on Atomic Energy Congress of the United States Eighty-Fifth Congress First Session on Development, Growth, and State of the Atomic Energy Industry - 1957, (1957).

${ }^{64}$ Bulletin of the Atomic Scientists XIII (September 1957): 271.

${ }^{65}$ H. A. C. McKay, "The Cento Institute of Nuclear Science in Tehran," Nature 186, no. 4724 (1960): $513-$ 515.

${ }^{66}$ H. A. C. McKay, "The Cento Institute of Nuclear Science in Tehran," Nature 186, no. 4724 (1960): 513515 .

${ }^{67}$ Great Britain. Parliament. House of Commons, Parliamentary papers, Volume 9, (HMSO, 1959).
} 
As the Center's director, H. A. C. McKay described the internal workings of the Center in Nature, "All the CENTO countries contributed to the running of the Institute. Its scientific policy was in the hands of the Scientific Council consisting of a leading scientist from each of the four countries; the United States sent an observer. The Scientific Council reported to the Economic Committee of CENTO, and in general administrative matters the Director of the Institute maintained liaison with the Deputy Secretary General for Economic Affairs of CENTO."68 The main thrust in the Center's research and training activities was on "radioisotope work, with some bias towards agricultural applications. ${ }^{, 69}$ There is some evidence in CENTO meetings minutes, coming especially from Pakistani representatives, suggesting the United States should consider deploying nuclear weapons in CENTO countries à la NATO. Iran, nervous about the Soviet Union's nuclear saber rattling over its CENTO membership and uncertain whether US extended deterrence would alleviate or aggravate its security anxieties, never embraced the idea.

In the very same year, Iran made preliminary arrangements to establish a $5 \mathrm{MWe}$ reactor at the Tehran University for which, on May 8, 1959, Tehran requested an amendment to the 1957 agreement allowing Tehran to receive HEU (90\% enriched U235) and Plutonium from the United States. ${ }^{70}$ The U.S. government, after inquiring as to

\footnotetext{
${ }^{68}$ H. A. C. McKay, "The Cento Institute of Nuclear Science in Tehran," Nature 186, no. 4724 (1960): 513515.

${ }^{69}$ H. A. C. McKay, "The Cento Institute of Nuclear Science in Tehran," Nature 186, no. 4724 (1960): 513 515 .

${ }^{70}$ Letter. United Stats Atomic Energy Commission. From Clark C. Vogel, Acting Director, Division of International Affairs to Mr. Assadollah Fahimi, First Secretary, Embassy of Iran to the United States May 26, 1959. RG 59 General Records of the Department of State Office of the Secretary Special Assistance to Secretary of State for Atomic Energy and Outer Space General Records Relating to Atomic Energy Matters, 1948-1962 Box 500. National Archives at College Park, College Park, MD.
} 
the design and construction of the reactor, the organizational configuration for its operation and utilization, the key personnel of the facility and "particularly the research and training program which was planned for the utilization of the reactor", and the "particular objectives" that had prompted Tehran to shift from the initially proposed $1 \mathrm{MWe}$ to the $5 \mathrm{MWe}$ reactor, did not grant Tehran's request. ${ }^{71}$ After an exchange of multiple letters, the United States, in anticipation of the fact that Tehran Research Reactor (TRC) would not be completed until the nuclear agreement's expiration on April 27, 1964 decided not to go along with amending the agreement. The Department of State instead, citing the policy of the US government "to encourage its bilateral partners, wherever practical, to satisfy their requirements for special nuclear materials through the International Atomic Energy Agency," referred Iran to the IAEA to obtain the HEU and plutonium it required. ${ }^{72}$

As time wore on, the Shah's fascination with atomic energy went beyond cooperation with the United States within the Atoms for Peace framework (this was in no small part thanks to Washington's stringent conditions for cooperation) and expanded toward Europe. For instance, on May 7, 1959 during a three-day visit to Great Britain the Shah paid a high-profile visit to the Atomic Research Establishment at Harwell during

\footnotetext{
${ }^{71}$ Letter. United States Atomic Energy Commission. Letter from A. A. Wells, Director of Division of International Affairs to Dr. Ali Gholi Ardalan Iranian Ambassador to the United States, June 24, 1959. RG 59 General Records of the Department of State Office of the Secretary Special Assistance to Secretary of State for Atomic Energy and Outer Space General Records Relating to Atomic Energy Matters, 1948-1962 Box 500. National Archives at College Park, College Park, MD.

${ }^{72}$ Letter. Secretary of State to the Charge d'Affaires ad interim of Iran in reference to the Ambassador's note of May 11, 1962. August 29, 1962. RG 59 General Records of the Department of State Office of the Secretary Special Assistance to Secretary of State for Atomic Energy and Outer Space General Records Relating to Atomic Energy Matters, 1948-1962 Box 500. National Archives at College Park, College Park, MD.
} 
which Lord Edwin Plowden, Chairman of the UK Atomic Energy Authority (AEA), gave him a guided tour of the Dido reactor. ${ }^{73}$

As touched upon earlier, the Shah's personal fascination with nuclear technology and the pomp and circumstance accompanying it is testified to by his enthusiastic presence in the extravagant inauguration ceremony marking the conclusion of the first nuclear agreement between Iran and the USA in April 1957. ${ }^{74}$ Along the same lines was the replacement in 1959 of the Bagdad Pact Nuclear Center by the CENTO Institute of Nuclear Science headquartered in Tehran and inaugurated by the Shah. ${ }^{75}$

This was followed, in July 1960, by Iran hosting the Cento Symposium on Nuclear Science in Hamadan. Experts from the CENTO member states, the US and France attended the symposium. Among the issues discussed was the possible uses of a large research reactors, and the value to the region of some of the larger nuclear instruments. During the meetings Tehran hinted at its interest in exploring the more operational aspects of the atom like nuclear energy.

Although amounting to no more than some preliminary gestures geared toward generating personal gravitas for the Shah and symbolic prestige for the country, the issue of the atom for Iran in the late 1950s and early 1960s could also be situated within a broader context. The nuclear effort, in addition to highlighting the Shah's efforts to broaden and consolidate his domestic prestige and authority base in the post-Mosaddeq era, also marks the initial phase of the young monarch's maturation into the "national

\footnotetext{
${ }^{73}$ Shah's Visit to Atomic Energy Research Establishment, May 14, 1959, http://www.britishpathe.com/record.php?id=64276 (accessed April 9, 2011).

${ }^{74}$ Rouhollah K. Ramazani, The United States and Iran: The Patterns of Influence (New York, NY: Praeger, 1982).

${ }^{75}$ Great Britain. Parliament. House of Commons, Parliamentary papers, Volume 9, (HMSO, 1959).
} 
security leader" he became toward the 1970s. As professor Ramazani aptly points out, in this period "Iran's foreign policy became clearly the Shah's foreign policy after the overthrow of the Mosaddeq regime. As such, it primarily reflected his perception of the Iranian position in world politics, his assumptions about the nature of the Iranian problem, and his projected solution for that problem.".76

Arguably "modernization" as a broadly conceived theme best encapsulates the gist of HIM's strategy of choice to energize Iran's leap forward and assuage its multiple social, political, and economic ailments. The theme figures prominently both in the substance and stylistics of the Shah's modus operandi in this period. Again, as Ramazani points out, "Unlike Mosaddeq, who assumed that the root cause of Iranian malaise was the pernicious influence of the British, the Shah might appear to have assumed that the social and economic backwardness of Iran was the most fundamental reason." Military security assumed such a prominence within this framework for the Shah that he observed, "freedom-loving peoples forget—but Communist powers never forget— that most of the world's economically underdeveloped countries are also militarily underdeveloped.",77 This inextricable and mutually reinforcing correlation between modernization and military prowess remained a bedrock component to the Shah's international posture with manifest implications for the intense politicization and securitization drift of Iran's nuclear program under his rule.

A natural consequence of this paradigm was that the Shah's resource allocation priorities were grossly lop-sided in favor of military purchases. This translated into

\footnotetext{
${ }^{76}$ R.K. Ramazani, Iran's Foreign Policy, 1941-1973: A Study of Foreign Policy in Modernizing Nations (University Press of Virginia, 1975).

${ }^{77}$ Ibid.
} 
unremitting US concern over the Shah's long-term or subterranean intentions since he would invariably tilt toward defense at the expense of development even under the most trying financial straits. One could argue that within this generic framework (defined by HIM's laser-focused attention on the security dividends of modernization) the eventual securitization of the Iranian nuclear program under the Shah by Washington was inevitable. Put crudely, the kind of cart blanche the monarch had given his nuclear superstar and bureaucratic celebrity Dr. Etemad was simply hard to reconcile with a purely civilian nuclear enterprise with no military rewards to extract down the road.

Viewed from this perspective, a case can be made that the decision to play with the idea of the nuclear was a by-product of the Shah's fascination with modernization. This was a perennial leitmotif in HIM's addresses to the nation as he was trying to transplant the modern world's (donya-ye motejadded as HIM used to call it in Persian) politico-economic values and socio-psychological attitudes onto the country's national psyche. Having said that, it is hard to gauge the outer limits of the Shah's nuclear imagination and expectations in this era as his eagerness to overcome the puppet image that had bruised and scarred his image after the 1953 coup and his desire to project hegemonic power onto the domestic and regional scenes evolved significantly in this period.

Closely monitoring the evolutionary trajectory of the Shah's passion for hegemonic power, the Americans were also extremely mindful lest they might excessively whet the Shah's appetite in the nuclear direction. Despite this cautiousness, though, the declassified evidence demonstrates that Washington briefly gave some thought to the idea of deploying nukes on Iranian territory considering the country's 
geostrategic indispensability to the Cold War. This was not to be, however as it would, in Washington's judgment, introduce unnecessary escalatory kinks to US relations with Moscow. Although the Americans went so far as to consider using nuclear weapons against the Soviet Union to defend Iran against a strategic Soviet attack in the $1950 \mathrm{~s}^{78}$ and a 1957 "Special National Intelligence Estimate" placed Iran squarely at the heart of the Soviet Union's strategic concerns, the US national security apparatus stopped short of recommending deployment of nuclear weapons systems in Iran on the grounds it "would probably cause the most serious concern of all possible areas of deployment. US deployment there would involve the possibility that, "in spite of the risk of counteraction by the US and the Baghdad Pact countries, the USSR might move forces into Iran, citing the provisions of the 1921 treaty. It would, in any event, be a reversal of previous US and Western policy against stationing troops in Iran., ${ }^{, 79}$

Providing NATO-like extended deterrence to the CENTO was also deemed ill advised by Washington. "In keeping with U.S. policy and legislation", the United States Department of State advised against giving the CENTO members "encouragement that the United States intended to provide to them, or share with them, any of its nuclear capabilities." Not to completely alienate CENTO countries (and to confer some semblance of defensive alliance on the CENTO), however, Washington made known its discretionary "unilateral plans to use tactical nuclear weapons in support of CENTO forces in time of global war," adding that "the nuclear weapons which will be allocated

\footnotetext{
${ }^{78}$ John Foster Dulles Views on Strategic Concept, Top Secret, Memorandum of Conversation, April 7 , 1958, 10 pp. Collection: U.S. Nuclear History Item Number: NH00099 Origin: United States. Department of State. Policy Planning Staff.

${ }^{79}$ Probable Sino-Soviet Reactions to U.S. Deployment of Nuclear Weapons Systems, Secret, Special National Intelligence Estimate, SNIE 100-7-57, June 11, 1957, 5 pp. Collection: Soviet Estimate Item Number: SE00202 Origin: United States. Director of Central Intelligence.
} 
for this purpose will not be deployed to the CENTO area until the United States determines that the requirement exists. ${ }^{\prime 80}$ This combination of ambiguous security guarantees, however, fell well short of Iran's security expectations as the most vulnerable CENTO country that didn't enjoy Turkey's NATO or Pakistan's SEATO status.

\section{The Monarch's Security Expectations}

As the 1960s wore on, the Shah's "almost pathological fear" of Nasserism and its metastasis into the Persian Gulf region came to dominate HIM's list of national security concerns. In 1964, in an attempt to "immunize" the region against Nasser's venomous influence and to consolidate Iran's position in the region in anticipation of British withdrawal in 1971, Iran embarked on a comprehensive effort to cultivate economic ties with Kuwait, Qatar, and Trucial Sheikhdoms. ${ }^{81}$

The Shah's exaggerated feeling of vulnerability from the Persian Gulf coupled with his "burgeoning self-confidence", as some US Embassy cables put it, was a perennial theme in Iran's foreign relations in the mid 1960's. The Americans felt the actual manifestation of this newfound sense of hegemony on multiple fronts. Chief among them was HIM's brutal repression of the domestic opposition, his reformmindedness specifically the so-called "white revolution," and his new policy of closer ties with the USSR and the Communist Countries of Eastern Europe. The most consequential of the Shah's novel grandstanding postures, however, was a rabid public opinion campaign to "demonstrate that he was no longer an American stooge" and to cultivate a

\footnotetext{
${ }^{80}$ Secret. Ninth CENTO Ministerial Council Session. Basic Assumptions for Global War and Tactical Nuclear Weapons. April 17, 1961. National Archives at College Park, College Park, MD.

${ }^{81}$ Confidential. Airgram. Department of State American Embassy, Tehran Recent Developments in Iranian Policies and Attitudes Toward the Persian Gulf Area. February 27, 1964. RG 59 General Records of the Department of State Central Foreign Policy Files, 1964-1966 Box 2330 National Archives at College Park, College Park, MD.
} 
new image of himself by decreasing his dependence on the United States for military procurements aimed at throwing Iran's weight around in the Middle East and North Africa. Also contributing to the Shah's "new-found self-confidence" in this era were: (1) the division, dispiritedness, and disarray created in leftist circles, particularly in the Communist movement, by the growing friendliness of the Soviets for the Shah; (2) the general disarray of other opposition elements, such as the National Front and certain religious circles; (3) the general detente between the USSR and the Western world and the new Soviet policy of wooing Iran rather than, as in the past, demonstrating hostility; and (4) the Shah's soaring oil income which made his independent policy economically possible. $^{82}$

One also has to bear in mind that that Shah's independent policy was arguably as much a by-product of Iran's changed fortunes and circumstances as the brainchild of the Shah's thinly disguised admiration for and his effort to emulate France's foreign policy under General Charles de Gaulle. Trying to take a page from de Gaulle's "politics of grandeur" (politique de grandeur) that saw Paris adopt a highly independent foreign policy posture and turned France into the world's fourth nuclear power, the Shah viewed Iran's placement in the Middle East comparable to that of France in continental Europe. Adopting this new paradigm, in the Shah's view, would enable Tehran to break itself loose from being a helpless hostage of politics of alliance and its vicissitudes in a tightly bipolar international system. This, in Chubin and Zabih's words, "involved 'bridge

\footnotetext{
${ }^{82}$ Confidential, Airgram, Department of State. Prospects for the Military Assistance Program in Iran. January 3, 1966. RG 59 General Records of the Department of State General Foreign Policy Files 1964-66 Political \& Defense Box 1733. National Archives at College Park, College Park, MD.
} 
building' with Iran's communist neighbor and its socialist allies in Eastern Europe, and included a diversification of foreign policy interests." 83

The Shah's gravitation toward a more independent -hence less manipulable and responsive to US persuasion and dissuasion- defense posture and his desire to devise mechanisms to deal with Tehran's security challenges "as he sees them" is well captured in a 1966 document where the Shah is described as literally "shocked" by the military treatment Pakistan, a close Iranian ally in the CENTO, received from the United States in the Indo-Pakistani War of 1965. The war was a transformative experience for the Shah and put him in a "new mood" vis-à-vis Iran's security precariousness and the depth and staying-power of Washington's security commitments:

"Although the Shah values the American security commitment contained in our 1959 bilateral agreement, he considers the Soviet threat less ominous and believes that in any case it is in America's interest that Iran be able to cope with regional threats (to preclude further Vietnams)... Developments affecting one of Iran's close allies have reinforced the Shah in his conviction that Iran must be prepared to stand on its own feet. U.S. action cutting off military assistance to Pakistan during the Indo-Pak crisis apparently left him profoundly convinced that not only might the United States not help Iran militarily in a conflict with the Arabs, it might cut off the flow of assistance it is now providing. Thus, the Shah was also disturbed to discover that when it comes to making available U.S.-supplied equipment (even that which he had purchased) to an ally such as Pakistan, delivery can be thwarted by the requirements of U.S. law. To the Shah this

\footnotetext{
${ }^{83}$ Sepehr Zabih Shahram Chubin, The Foreign Relations of Iran: a developing state in a zone of greatpower conflict (University of California Press, 1974).
} 
means that his two closest allies, Pakistan and Turkey, cannot assist Iran militarily against a non-communist aggressor without the risk of United States interference." ${ }^{, 84}$

Within this context, in Washington's judgment, having consolidated his position as both the monarch and the supreme ruler and decision-maker, the Shah in the mid 1960's, after a quarter century on the throne, enjoyed considerable self-confidence and self-sufficiency in his strategic judgments about "what [was] best for his people and how to achieve it." $" 85$

Also vividly detectable in this era is the Shah's dissatisfaction with the United States' under-appreciation of his contributions in turning Iran into "a progressive twentieth century nation-state" following the example of Cyrus and Darius. The Shah of the mid-1960's, ambitiously and "with a messianic zeal," assumed a "constructive role" for Iran in a Middle East "plagued by negativistic sloganism." Brimming with selfconfidence, the Shah, by the mid 1960s, had turned into a security-first leader for whom military aspects of the national interest took absolute precedence over and were prerequisites for social progress and economic prosperity. Following this ever-ingraining philosophy of viewing socio-politico-economic flourishing as derivatives of security, the Shah was rapidly increasing his military procurements. In 1966, for instance, he was pushing for "a second Hawk battalion, super-sonic interceptors, gap-filler radars and antiaircraft guns, Sheridan tanks, additional war reserve ammunition, a destroyer, and an air-

\footnotetext{
${ }^{84}$ Secret. Department of State, Department of Defense. Second Annual Review of the Memorandum of Understanding of July 4, 1964. May 7, 1966. RG 59 General Records of the Department of State General Foreign Policy Files 1964-66 Political \& Defense Box 1733. National Archives at College Park, College Park, MD.

${ }^{85}$ Secret. Department of State, Department of Defense. Second Annual Review of the Memorandum of Understanding of July 4, 1964. May 7, 1966. RG 59 General Records of the Department of State General Foreign Policy Files 1964-66 Political \& Defense Box 1733. National Archives at College Park, College Park, MD
} 
to-ground missile." The monarch also made no secret of his willingness to secure and procure the military hardware he deemed imperative from anyone willing to sell. For example, he made known to the Americans the availability of a Soviet high-speed interceptor aircraft at a "favorable price." 86

The disagreements in judgment between the Shah and the Americans on the strategic threat environment Iran was presently and prospectively facing were steeply spiking as the 1960s was drawing to a close and Iran's petrodollars were bulging. For instance, in a November 4, 1968 cable Stuart Rockwell, Deputy Assistant Secretary for Near Eastern and South Asian Affairs, took issue with the Shah's thesis about "a serious threat requiring an all-out defense effort by Iran" in the Persian Gulf. ${ }^{87}$

This independent mindset came even more conspicuously to a fore when HIM arrived more definitively at the realization that "the [US] commitment [toward Iran] was closely related to Soviet involvement in any threat to Iran" as opposed to being a purely bilateral commitment. With the Soviet threat growing "relatively latent," the Shah became more concerned about "a radical Arab nationalist threat from the South" that he preferred to fend off with indigenous Iranian force. ${ }^{88}$ Within this context, for example,

\footnotetext{
${ }^{86}$ Secret. Department of State, Department of Defense. Second Annual Review of the Memorandum of Understanding of July 4, 1964. May 7, 1966. RG 59 General Records of the Department of State General Foreign Policy Files 1964-66 Political \& Defense Box 1733, National Archives at College Park, College Park, MD.

${ }^{87}$ Secret, Deputy Assistant Secretary for Near East and South Asian Affairs Department of Defense Harry Schwartz to Stuart Rockwell, Deputy Assistant Secretary for Near Eastern and South Asian Affairs, (November 4, 1968) RG 59 General Records of the Department of State; General Foreign Policy Files, 1967-1969. Political and Defense Box 1733 National Archives at College Park, College Park, MD.

${ }^{88}$ Secret, US Embassy Tehran, Department of State, Special State-Defense Study Group on Overseas Bases June 19, 1968. RG59 General Records of the Department of State; General Foreign Policy Files, 19671969. Political and Defense. Def 12-5 Iran to DEF 9-4 ISR Box 1556.
} 
Iraq's acquisition of "more MIGs from the USSR and Lightnings from the UK" only intensified Iran's rapidly escalating anxieties from the Nasser-inspired Arab world. ${ }^{89}$

This international factor played an unmistakable role in circumscribing the scope and depth of the Shah's reliance on the United States for sub-existential security needs. As touched upon before though, reinforcing the international factor in HIM's more selfreliant posture was an indispensible domestic ingredient: Iran's ever-swelling national coffer thanks to windfall oil revenues and other financial resources. This domestic economic factor was essentially shifting Iran-US relations away from one of "donorrecipient" onto a more "commercial basis." One obvious manifestation of this transformation was the United States "terminating its AID assistance" and decreasing the grant component of its military cooperation to Iran and imposing more stringent credit terms on the Shah's insatiable appetite for military hardware.

\section{The INP Muddles Through}

As the fissures in threat judgment between Iran and the United States were widening and proliferating, Tehran's burgeoning and predominantly symbolic nuclear program was slowly edging forward. The trajectory of Iran's nuclear program received a vigorous conceptual jumpstart with Akbar Etemad's return to Iran from Switzerland in June 1965. The son of an affluent merchant from the ancient city of Hamedan in northwestern Iran, Etemad received his secondary education in the elite American College of Tehran known as Alborz High School before pursuing a higher education in electrical engineering in Switzerland's École polytechnique de l'Université de Lausanne

\footnotetext{
${ }^{89}$ Confidential. Airgram. Department of State. American Embassy in Tehran. Prospects for the Military Assistance Program in Iran, January 3, 1966; RG 59 General Records of the Department of State General Foreign Policy Files 1964-66 Political \& Defense Box 1733
} 
(EPUL). Upon graduation, Etemad took up a research position in Baden (Switzerland) based Brown Boveri, a company specializing in nuclear power generators. Thereafter, he moved to Switzerland's main reactor research center Institut Federal de Recherche en Matiere de Reacteura while pursuing a doctorate degree in Reactor Physics at the University of Lausanne. Following graduation in 1963, Etemad continued working at the Institut for two additional years and established himself as an internationally known figure in the field of "nuclear reactor shielding" giving consultation to the IAEA.${ }^{90}$ In 1956, having severed his ties with Iran's communist Tudeh Party, a disillusioned Etemad heeded his inner calling and decided to return to Iran and "give back to his home country."

Upon his return to Iran in 1965, Etemad took on a managerial position in accelerating the completion of The Tehran Research Reactor whose commissioning had, much to the Shah's annoyance, almost ground to a halt. Etemad, whose bureaucratic dexterity was increasingly shining through, also engineered the relocation of the Iran Atomic Energy Commission (IAEC) from the Ministry of the Economy to the Plan Organization in 1967. The new IAEC in the Plan Organization, whose founding charter Etemad drew up, would streamline and synchronize all policy-formulating and decisionmaking functions related to nuclear energy. As Etemad later recalled, the relocation of the Iran Atomic Energy Commission coincided with the time the Plan Organization was preparing Iran's Fourth Development Plan (1968-1973) in which no mention was made of possible uses of nuclear energy for generating electricity.

\footnotetext{
${ }^{90}$ For more on Etemad's biography, see Abbas Milani, Eminent Persians: The Men and Women Who Made Modern Iran, 1941-1979 (Syracuse, NY: Syracuse University Press, 2008) and Akbar Etemad, Barnamehye enerji-ye atomi-ye iran, talash-ha va tanesh-haa (Iran's Nuclear Energy Program, Hopes and Challenges), ed. Gholam Reza Afkhami (Bethesda, MD: Bonyad-e Motale'at-e Iran (Foundation for Iranisn Studies) 1997).
} 
With the establishment of the Ministry of Science, Scientific Research, and Higher Education in 1968, Etemad was placed in charge of its Scientific and Research Department that took on all nuclear R\&D responsibilities previously falling under the Plan Organization. While the responsibility for conceptualizing and operationalizing the atom was being shuttled between different government agencies, thanks to a lack of a meaningful national-level priority for the issue-despite HIM's avid personal interest in it- no major tangible breakthroughs transpired until late 1973. In the meantime, Etemad stayed in the Ministry of Science performing various duties as the head of the Institute for Research and Science and Education Planning and later as the Chancellor of his passion project, the newly founded Buali Sina (Avicenna) University in his hometown of Hamadan. $^{91}$

Among the most significant functions of the Plan Organization in the field of atomic energy was to "prepare for submission to the Atomic Energy Council drafts of legislative bills, decrees, and regulations" related to atomic energy. It was also tasked with assuming "direct control over all atomic installations and radioactive material." The IAEC also exercised "direct control over activities in the field of atomic energy within the ministries of government affiliated agencies, to establish coordination between the agencies and to examine atomic energy plans and budgets." As part of this function it was mandated to "encourage various government agencies to use atomic energy to implement or to assist in the implementation of Development and Industrial Plans such as the generation of power, the desalination of sea water." Also falling under the IAEC's tasks were preparing "necessary programs for training scientists and technicians in the fields of

\footnotetext{
${ }^{91}$ Gholam R. Afkhami, The Life and Times of the Shah (Berkley: University of California Press, 2009).
} 
atomic energy" and "attracting foreign aid of all kinds as well as for distributing it among the various government agencies."${ }^{.92}$

Related to this bureaucratic reshuffle, on its April 22, 1967 meeting the Iranian Council of Ministers approved a decree establishing the "Atomic Energy Council" under the chairmanship of the Prime Minister. The body's broad platform was to convene every three months to "concentrate activities in the field of atomic energy." The Council comprised of the Minister of Economy, the managing Director of the Plan Organization, the Chancellor of the Tehran University, the Chancellor of another university, and four Atomic Energy experts selected by the Prime Minister. The most important function of the newly established body was to "determine overall policy in the field of atomic energy as well as to determine priorities. ${ }^{, 93}$

In this period, the 1957 nuclear agreement between Tehran and Washington went through two revisions in 1964 and 1969 respectively. The 1964 amendment was especially of operational significance since it would provide for the transfer of highly enriched uranium for the Tehran Research Reactor (TRR) and for gram quantities of other nuclear material for research projects. The most significant change in the 1969 amendment was that it modified the 1964 agreement to "permit fueling of reactor

\footnotetext{
${ }^{92}$ Unclassified. US Embassy Tehran to Department of State. Iranian Atomic Energy Commission. May 24, 1967. National Archives at College Park, College Park, MD.

${ }^{93}$ Unclassified. US Embassy Tehran to Department of State. Iranian Atomic Energy Commission. May 24, 1967. National Archives at College Park, College Park, MD.
} 
experiments in addition to research reactors. ${ }^{194}$ Iran also signed an agreement with Canada on January 7, 1971 for "Co-operation in the Peaceful Uses of Atomic Energy."

On November 25, 1967, the 5MWe swimming pool-type Tehran Research Reactor (TRR) was inaugurated on the newly constructed Amirabad campus of the University of Tehran. TRR, built in two vaults and a five-story building and dedicated by the Shah and the Queen, was part of the contract the University of Tehran had concluded with AMF atomics in 1958. The reactor was comparable to the ones the United States had constructed for Israel and Pakistan and was capable of producing up to 100 grams of plutonium per year. ${ }^{95}$ The reactor, built within the Center for Nuclear Studies and the research labs it housed at the University of Tehran, was constructed under the Shah's direct authority. At this point the Center for Nuclear Studies staffed some seventy nuclear experts and technicians trained in Europe and the United States. As part of the TRR project, in September 1967 the United States supplied about 5 kilograms of HEU (93\% enriched) to Iran to fuel the TRR in addition to about 100 grams of plutonium as "start-up sources for research reactor." ${ }^{196}$ Iran, the USAEC, and the IAEA concluded an agreement

\footnotetext{
${ }^{94}$ USAEC Chairman Glenn Seaborg to the President Proposed Amendment to Agreement for Cooperation Between the Government of the United States of America and the Government of Iran, February 20, 1969. Country Files, Middle East: Iran. Richard Nixon Presidential Library and Museum, Yorba Linda, California.

${ }^{95}$ Unspecified Classification. Pakistan Nuclear Study. April 26, 1978 http://www.foia.cia.gov/docs/DOC 0000252641/DOC 0000252641.pdf (Accessed April 23, 2011).

96 "US Supplied Nuclear material to Iran," January 29,1980; in Digital National Security Archive quoted in The Nuclear Threat Initiative, Iran Nuclear Chronology, http://www.nti.org/e research/profiles/Iran/Nuclear/chronology 1957 1985.html (Accessed June 12, 2010).
} 
in June 1967 that would authorize the transfer of enriched uranium and plutonium to Iran under the IAEA supervision. ${ }^{97}$

The TRR went critical on November 4, 1967 in coincidence with the Shah's inauguration of the "Atoms in Action" Exhibition on Tehran University's Amirabad campus. This was an exhibition operated by the U.S. Atomic Energy Commission (USAEC) scheduled to run through November 1967. Referred to by the Department of State as "the largest combined educational-cultural-scientific foreign exhibit program of this nature of the U.S. Government and the most comprehensive on science and atomic energy," its objectives were to "advance the knowledge that atomic energy is one of the most effective means to further the betterment of mankind" and "to negate the notion that atomic energy and destruction are irrevocably associated."${ }^{.98}$

In his message to the ceremonial occasion, US President Lyndon B. Johnson called the Nuclear Science Demonstration Center and Exposition "an exposition of progress in Nuclear Science... and an operating laboratory and a meeting-ground where your [Iranian] scientists and ours will work side-by-side to learn more about nuclear energy and the many blessings that its peaceful development promises for mankind." $\mathrm{He}$ further expressed hope that the Center would prove a platform where "ideas about

\footnotetext{
${ }^{97}$ No. 8866 Contract for the transfer of enriched uranium and plutonium for a research reactor in Iran. Signed at Vienna, on 10 March, at Teheran, on 10 May, and at Vienna, on 7 June 1967. http://treaties.un.org/doc/Publication/.../volume-614-I-8866-English.pdf (Accessed July 15, 2011).

${ }^{98}$ Unclassified. Department of State to US Embassy Tehran, Participation and Assistance, AEC Atoms in Action Nuclear Science Demonstration Center and Exposition, Tehran. July 24, 1967. National Archives at College Park, College Park, MD.
} 
nuclear science will find a useful forum for exchange, will encourage other similar projects of mutual benefit for our countries and other nations of the world." 99

But arguably the most consequential of Iran's nuclear actions in this period was Tehran's rush to accede to a host of international organizations and treaties aimed at establishing an international nuclear regime. As part of this policy, Tehran ratified the International Atomic Energy Agency's (IAEA) statute on May 16, 1958, less than a year after the nuclear watchdog agency's establishment on 29 July 1957. On August 9, 1963 Iran signed the Partial Nuclear Test Ban Treaty (PTBT) and ratified it on 23 December 1963. Tehran also signed and ratified the Seabed Arms Control Treaty in 1971.

The most significant of these treaty accessions, however, was Iran's signing of the Treaty on the Non-Proliferation of Nuclear Weapons commonly known as the NPT on the day it was opened for signature on July 1, 1968. Tehran ratified the NPT on February 2, 1970 and concluded a safeguards agreement with the IAEA that entered into force on May 15, 1974 establishing its rights and responsibilities under NPT articles. Some have speculated that Tehran was coerced into signing the NPT by the United States as the finalization of the sale of F-4 Phantom fighter-bombers was implicitly conditioned on the treaty's ratification. ${ }^{100}$ Whatever might have prompted such a hasty decision, however, there exists a near consistency and consensus in the declassified documents and people who have commented on the subject that a serious debate never took place on the pros and cons of joining the treaty. Assad Homayoun believes that the decision was made

\footnotetext{
${ }^{99}$ Limited Official Use. Department of State to Embassy Tehran. Advance Notice of President Johnson's Message. October 10, 1967. National Archives at College Park, College Park, MD.

${ }^{100}$ Seyyed Hossein Mousavian, Protokole Elhaghi va Rahborde Jomhourye Eslamye Iran (The Additional Protocol and The Islamic Republic of Iran's Strategy) (Tehran: Expediency Council Strategic Research Center, 2007). P 213.
} 
personally by the Shah simply to avoid antagonizing the Americans who were pushing hard for garnering maximum signatures for the treaty. ${ }^{101}$ This was a decision that many in the Iranian nuclear "epistemic community" later came to lament. Chief among them was Akbar Etemad, the father of the Iranian nuclear program who, with his characteristic candidness, frequently referred to the "inherently discriminating nature" of the treaty, called the decision to join it "imprudent in the first place", and underlined the Western countries' consistent violation of articles IV and VI, and advocated Iran's withdrawal from it. ${ }^{102}$

The Shah's nonchalant attitude toward Tehran's non-proliferation obligations under the NPT regime when he was being pushed on the question of Iran's nuclear ambitions in the mid 1970s was a manifest symptom of Tehran's reluctant membership in the treaty. This got some Iran observers wondering whether the conspicuous absence of the NPT as a proliferation dissuader in Iran's nuclear discourse was a sign that by 1974 the treaty had grown "too dated to be relevant" as far as a completely transformed Iran was concerned. ${ }^{103}$

On another front, in 1972 Iran's nuclear thinking inched closer to finding a preliminary sense of strategic direction when the government went public with its

\footnotetext{
${ }^{101}$ Assad Homayoun, interview by Mohamad Homayounvashtrans. Washington D.C. (July 23, 2010).

102 Akbar Etemad, interview by Enayat Fani, "Gharb Dorough Migooyad, Iran Bayad Hastei Shavad (The West is Lying, Iran Should Go Nuclear),"

http://www.bbc.co.uk/persian/iran/2009/11/091101_ag_be_ebarate_digar_etemad.shtml, BBC (Accessed November 1, 2009).

${ }^{103}$ George H. Quester, "The Shah and the Bomb," Policy Sciences 8, no. 1 (March 1977): 21-32.
} 
principled intent to build multiple nuclear power plants within the next decade or so. ${ }^{104}$ The country, however, still woefully lacked the requisite financial, scientific, and human resources capabilities commensurate with such a declaratory vision.

Things took a dramatic turn in 1973, however, following the October oil crisis when the members of the Organization of Arab Petroleum Exporting Countries or OAPEC (consisting of the Arab members of OPEC, plus Egypt, Syria and Tunisia) proclaimed an oil embargo "in response to the U.S. decision to re-supply the Israeli military" in the Yom Kippur War. As we will see in the next chapter, Iran's refusal to jump on the Arab bandwagon and the windfall revenues generated by the ensuing oil bonanza gave the Shah both the requisite strategic latitude and the financial wherewithal to embark upon an ambitious and cost-intensive nuclear enterprise.

\section{Deterrence Creeps into the Monarch's Security Lexicon}

The problem of keeping the Shah's military appetite within proportional dimensions entered a paradigmatically new era in 1969 with the finalization of the British withdrawal from the Persian Gulf region slated for 1971. The Shah, still wary of the USSR's sinister, subversive, and aggressive intentions-- albeit now cloaked in a more surreptitious fashion-- considered the Peacock Throne as heir apparent to Whitehall and deemed Tehran a natural candidate to fill London's stabilizing role in the region and to stem the feared radicalization drift of the emerging Arab nation-states.

Although the Nixon administration continued, just like its predecessor, to insist that the Shah's security anxieties were hyperbolic, his security expectations were hegemonic, and his reading of Iran's role was "overdrawn", there was decidedly a

\footnotetext{
104 "Nuclear Plant Study Started," Kayhan International, December 19, 1972; Quoted in The Nuclear Threat Initiative; Iran Nuclear Chronology

http://www.nti.org/e_research/profiles/Iran/Nuclear/chronology_1957_1985.html (Accessed June 14, 2010)
} 
generic sense of recognition in Washington that HIM was irreversibly "wedded" to his judgment on Iran's strategic environment, its operational imperatives, and the fact that the country had the "wherewithal to look to other arms sources if he decided the US (was) not sufficiently meeting his demands for arms." The alienating, alarming, and provocative impact of this maximalist security posture and insatiable thirst for sophisticated weaponry figures prominently in the United States' appraisal of power relativities in the Middle East and Iran's placement in it.

Also with the advent of the Nixon administration, one notices a new theme with potential nuclear overtones entering the tenor of the Shah's security posture: deterrence. The Shah, starting as early as the early 1970s, developed a rather novel security preoccupation essentially to the effect that "only a strong deterrent posture can provide the necessary guarantee of Iran's security against radical Arab nationalist incursions into the Gulf region." 105

The Shah, on many occasions, kept reminding the Americans of the Soviet Union's "grand design" to penetrate the Middle East following the British withdrawal and the need for Iran to have a credible deterrent posture to fully implement its own and the region's vital security and stability requirements within the framework of the Nixon Doctrine. His Imperial Majesty even went so far as to admonish the Americans for having sidetracked themselves onto a marginal and distracting theater in Vietnam and for not fully appreciating the high-stakes global game unfolding in the Middle East. This time around, he was even more scathing in his criticism of the way Washington was

\footnotetext{
${ }^{105}$ Secret. U.S. Department of State. Director of Intelligence and Research. Iran: Shah's Views of Iranian Defense Needs on the Eve of US Visit. October 17, 1969. Country Files, Middle East: Iran. Richard Nixon Presidential Library and Museum, Yorba Linda, California.
} 
patronizingly deciding for Iran what military wherewithal it needed while shying away from offering iron-clad NATO style security guarantees to Tehran.

For the Shah, the most vivid manifestation of the half-heartedness of the United States' security commitments to Tehran was its refusal to join CENTO as a full-fledged member. Further aggravating the Shah's concerns was Washington's dismissive attitude toward and lack of sympathy for his diagnosis of the gravity of the unfolding situation in the Persian Gulf, Iran's pivotal role in it, and the formidable odds Tehran was up against. $^{106}$

In the U.S. intelligence community's judgment, the Shah viewed US reluctance, denial, or deferral on providing sophisticated weaponry to Iran as emblematic of the United States' dwindling "regard for him and for his policies" and as a sign of Iran getting "downgraded" on Washington's priority list. As a matter of fact, the intelligence community projected, in as early as 1970 , that HIM would reorient his policies away from the United States "in the direction of closer ties with certain West European states, a more accommodating attitude toward the USSR, resistance to U.S. advice on international issues, probably increased pressures on US oil interests, and possibly termination of US special facilities and military over-flight rights." ${ }^{107}$

One can logically expect the new theme of deterrence, along with the Shah's condescending attitude towards international norms and regimes, to have played at least a permissive and facilitating function in the securitization drift of a full-fledged Iranian

\footnotetext{
${ }^{106}$ Secret. From Douglas MacArthur, Embassy Tehran to Secretary of State. March 19, 1970. Shah's Views on Procurement Military Equipment Country Files, Middle East: Iran. Richard Nixon Presidential Library and Museum, Yorba Linda, California.

${ }^{107}$ Secret. Director of Central Intelligence. Special National Intelligence Estimate. Iran's International Position. September 3, 1970. http://www.foia.cia.gov/docs/DOC 0000238922/DOC 0000238922.pdf (Accessed April 15, 2011).
} 
nuclear program, especially considering Tehran's uncompromising insistence on possessing full fuel cycle and reprocessing rights in the mid-1970s.

Another theme that crept into the Shah's security judgments in this era was one of Iran emerging from under the shadow of the United States and other great powers and Tehran's eagerness to embrace the operational imperatives of acting like a hegemonic power in the Persian Gulf. As early as 1969, the Monarch conveyed his unequivocal judgment to Washington that he had come to believe "time had passed when great powers could intervene in the Middle East and Asia," and that Iran should be given broad latitude in regaining its authority as the master of its own house capable of accurately diagnosing its security shortcomings and the ways and means to address them. ${ }^{108}$

This theme in the Shah's foreign policy posture was additionally reinforced by HIM's growing conviction that as the prevailing systemic atmosphere had deescalated to one of détente, the United States would leave Iran to its own devices or at least pull its nuclear punches were it to be attacked by the USSR or its regional allies. ${ }^{109}$ These two factors had undeniable implications for the Monarch's insistence on nuclear independence in the mid-1970s and the trepidation with which the United States was monitoring Iran's nuclear leap forward. In other words, the ubiquitous desire for selfsufficiency that began in the realm of security gradually grew into a predominant theme in the Shah's strategic thinking subsequently finding expression in the nuclear field with Iran insisting on an indigenous full fuel cycle capacity.

\footnotetext{
${ }^{108}$ Secret. From Douglas MacArthur, Embassy in Tehran to Secretary of State. Shah's Views on Iran's Military Requirements. November 1969. Country Files, Middle East: Iran. Richard Nixon Presidential Library and Museum, Yorba Linda, California.

${ }^{109}$ Confidential. From Ambassador Embassy Tehran to Secretary of State. Iraq: Soviet Efforts to Penetrate Middle East; Iran's Need for Adequate Military Establishments. October 13, 1969. Country Files, Middle East: Iran. Richard Nixon Presidential Library and Museum, Yorba Linda, California.
} 
Iran's strategic concerns in a radicalizing Middle East and the Shah's relentless, yet reluctant, efforts to outgrow Tehran's subservient dependence on the United States and alleviate its adverse implications are recurrent themes in the Shah's conversations with the Americans. By way of example, in a 1970 cable, US ambassador to Iran, Douglas MacArthur II makes mention of the Shah's "absolute conviction-- or obsession-that unless he substantially strengthens his military posture, the Arab side of the (Persian) Gulf will, after British withdrawal, fall before massive radical Arab campaign of subversion encouraged by Soviets with Iran standing alone." ${ }^{110}$ Washington, however, questioned the validity of these threat judgments by the Shah indicating that the Shah's "exaggerated" threat perception and his craving for preponderant deterrent capability were deliberate plans that betrayed a more subterranean motive. This assessment threw a thoroughly different light on the Monarch's hysterical threat assessments following the anticipated British withdrawal from the region.

America's disagreement with the Shah's threat perceptions reached a pitch in September 1970 when the Defense Department asked the intelligence community to do a Special National Intelligence Estimate (SNIE) on the "military threat" facing Iran.

The resultant memo, drawing a parallel between Iran's predicament and that of Israel, noted that the Shah was not simply seeking to deal with "visible threats" (those, in the memo's judgment, were not imminent or massive enough to "justify" the military hardware he was seeking), but was keen on a military posture formidable enough to have

\footnotetext{
${ }^{110}$ Secret. Telegram. Department of State. From Ambassador Embassy Tehran to Secretary of State. April 1, 1970. Country Files, Middle East: Iran. Richard Nixon Presidential Library and Museum, Yorba Linda, California.
} 
a "deterrent" impact on the would-be aggressors so that Iran would be above challenge at least in the Persian Gulf. ${ }^{11}$

Such a force would dissuade potential aggressors from attacking the Persian homeland or fettering with Iran's maneuverability in the Persian Gulf and the Indian Ocean. According to the 1970 SNIE on Iran's international position, the Shah, "acutely conscious of Iran's great past", saw the British disengagement as presenting not simply a threat but also an historic opportunity for Iran to project power and reassert the kind of leadership it was entitled to. ${ }^{112}$

The Shah called such an impressive posture by Iran in the Middle East a "Policy of Wisdom," one that purported to portray Iran as a country that made rational decisions and whose strength was the keystone of security in the Middle East. A theme the Shah was fond of sounding to the Americans every opportunity he got was that "insofar as the Middle East is concerned, it is important to the U.S. and the Free World that Iran be capable of providing for her security and that of the Gulf. ... Iran must be capable of handling local conflicts and she should not look to the U.S. to become involved except in case of general war." Yet, to the Americans, the operational military imperatives of Iranian-style wisdom were steeply moving upward and bordering on extravagant. ${ }^{113}$

\footnotetext{
${ }^{111}$ Secret. Memorandum for Dr. Kissinger. From Harold Saunders. Memo from Mr. Helms on Iran. September 2, 1970, Country Files, Middle East: Iran. Richard Nixon Presidential Library and Museum, Yorba Linda, California.

${ }^{112}$ Secret. Director of Central Intelligence. Special National Intelligence Estimate. Iran's International Position. September 3, 1970. http://www.foia.cia.gov/docs/DOC 0000238922/DOC 0000238922.pdf (Accessed April 15, 2011).

${ }^{113}$ Secret. Memorandum for Record. Audience with His Imperial Majesty, 6 April 1970, General Earle G. Wheeler, Chairman, Joint Chiefs of Staff, and Major General H. A. Twitchell in Attendance. April 8, 1970. Country Files, Middle East: Iran. Richard Nixon Presidential Library and Museum, Yorba Linda, California.
} 
To address this issue in the early 1970s Washington was engaged in a diplomatic campaign to put a reality check and a sense of perspective on HIM's power expectations. As part of this policy, for instance, the U.S. Secretary of Defense urged Under Secretary of State Elliot Richardson to knock some sense of proportionality into the Shah in his 1970 visit to Iran:

"Although the Shah is aware of these facts, it does not appear that he fully recognizes, or is willing to recognize, the special position and consideration Iran has in its military relationship with the U.S. As you are aware, these include the largest MAAG ${ }^{114}$ outside SEA ${ }^{115}$, almost one third of our FMS credit ${ }^{116}$, the USAF F-4 Technical Assistance Field Team (TAFT), one-half of all our foreign jet pilot training spaces, and DoD assistance in the M-47 retrofit program."117

In December 1970, having sensed the United State's sense of trepidation and suspicion over Iran's purported lack of proportionality in seeking military equipment, the Shah informed the Americans, in his newfound point blank style, that he was not after a "great imperial armed force like Kaiser Wilhelm or like Hitler," rather his strategic objective was to possess a nimble, efficient, and compact military that could "counter anything but a major Soviet attack." ${ }^{118}$

\footnotetext{
${ }^{114}$ Military Assistance Advisory Groups

${ }^{115}$ Southeast Asia

${ }^{116}$ Foreign Military Sales: A U.S. Department of Defense mechanism for conducting government-togovernment military equipment, services, and training transactions through revolving credit lines.

${ }^{117}$ Secret. From the Secretary of State to Honorable Elliot L. Richardson, Undersecretary of State April 14, 1970. Country Files, Middle East: Iran. Richard Nixon Presidential Library and Museum, Yorba Linda, California.

${ }^{118}$ Secret. From American Embassy Tehran to Secretary of State Washington, Shah's Views on Middle East Situation as it Relates to Iran's Security Requirements. December 10, 1970. Country Files, Middle East: Iran. Richard Nixon Presidential Library and Museum, Yorba Linda, California.
} 
In analyzing the Shah's changing posture vis-à-vis Washington, one should also take stock of Iran's amicable relations with Israel during this era and that relationship's indispensability for a Shah up against a reluctant U.S. administration to satiate his everincreasing thirst for military hardware. For instance, following reports that the United States Congress might be stonewalling the consummation of an F-4 deal, a disillusioned Shah in December 1970 made no bones about his true feelings "acidly" reminding his American audience that he could obtain all he wanted from Israel. ${ }^{119}$

One should also be cognizant of the fact that the Shah's Soviet allergy was diminishing in parallel with Iran's bulging oil revenues and his growing self-confidence coupled with Iran's perceived demotion in Washington's strategic calculus during the détente. The Monarch's independent attitude hit a new high mark in 1970 when the Shah reminded the Americans of his readiness to purchase military equipment from Moscowparticularly T-62 tanks - if the West were to give him the runaround on his military needs. ${ }^{120}$ This attitude, if operationalized and were the Soviets to sell significant amounts of military equipment to Iran, would be tantamount to a major defeat for the Americans as it would provide the Soviets with a foothold in Iran, a scenario to which the United States was avidly averse.

Another important factor that started developing in the late 1960s and early 1970s and appreciably contributed to the subsequent securitization drift of the Iranian

\footnotetext{
${ }^{119}$ Secret. From American Embassy Tehran to Secretary of State Washington, Shah's Views on Middle East Situation as it Relates to Iran's Security Requirements. December 10, 1970. Country Files, Middle East: Iran. Richard Nixon Presidential Library and Museum, Yorba Linda, California.

${ }^{120}$ Secret. Department of State Telegram. From American Embassy Tehran to Secretary of State Washington. Soviet Arms Offer to Iran. October 5, 1970. Country Files, Middle East: Iran. Richard Nixon Presidential Library and Museum, Yorba Linda, California.
} 
nuclear program in the mid-1970s was a gradually institutionalizing feeling in Washington that the Shah had an obsession with national prestige and was willing to go to any lengths to secure its hardware prerequisites. This was undermining, in Washington's judgment, the legitimacy of HIM's security concerns that he claimed were the main driving force behind Iran's quest for added power differentials vis-à-vis the rest of the Persian Gulf states. Pushed to its logical conclusion, this would entail the Shah seeking to follow Israel and India's suit in its vicinity and develop, at a minimum, a readily weaponizable nuclear capability.

As a matter of fact, in January 1972 in two separate meetings with US officials, Senator Stuart Symington and Ambassador MacArthur, the Shah underscored Tehran's opposition, on principle, to the nuclearization of "the Middle East and South-Asian areas adjacent to Iran." The Monarch, however, was quick to emphatically observe, "should a country such as India develop nuclear weapons capability at some future time, perhaps with Soviet assistance having China in mind, Iran would have to reconsider its present policy and would probably itself wish to develop a nuclear capability."121 The utter disregard for the NPT in the Shah's articulation of Iran's future nuclear posture a mere month before the treaty was up for ratification in the Iranian Parliament was hardly a reassuring sign of Iran's commitment to its contractual non-proliferation obligations.

Reinforcing these troubling comments by the Shah and contributing to the securitization slide of the Shah's nuclear program in the 1970s was also the Monarch's discounting, at times flat-out dismissive, attitude toward the Iranian armed forces' simple numerical superiority. The Shah, rather, wanted the kind of qualitative supremacy

\footnotetext{
${ }^{121}$ Secret. US Embassy Tehran to Secretary of State. Shah's Views on Nuclear Weapons in Mid-East Area. January 5, 1972. Country Files, Middle East: Iran. Richard Nixon Presidential Library and Museum, Yorba Linda, California.
} 
complete with state-of-the-art weaponry that would be unmistakably deterring of any would-be aggressors. Naturally, for a decision-maker with such a predisposition the nuclear option would be irresistibly tempting. In the Shah's view, the key imperative for Iran to properly discharge its role as the sole "guardian and protector" of two third of world's oil reserves in the Persian Gulf was unrestricted access to state-of-the-art military hardware.

For a leader with an acute encirclement mentality (the Shah felt particularly vulnerable in the Strait of Hormuz or as he called it Iran's "jugular vein") possessing a formidable military apparatus assumed existential proportions. For instance, in a 1973 trip to the United States, he was seeking to purchase Grumman's swing-wing F-14 Tomcat Navy fighters complete with its "full suit of sophisticated equipment" including the Hughes AIM 54-A Phoenix missiles and a long-range state-of-the art radar. ${ }^{122}$ It is interesting to note that these Phoenix missiles were capable of carrying nuclear warheads. The Shah justified the interest in the F-14 purchase as a response to frequent high-altitude flights by the Soviets' MIG-25 over Iranian territory for which Tehran's existing F-4s were no match. To further boost Iran's air supremacy vis-à-vis the Soviet Union and its Baath Socialist ally in Baghdad, the Shah also expressed interest in the McDonnell Douglas's F-15 Eagle, the most advanced tactical combat fighter in the U.S. Air Force at the time. ${ }^{123}$ This insatiable appetite for sophistication and supremacy in the military wedded to HIM's "impatient and Napoleonic vision of history" (where Iran was

\footnotetext{
${ }^{122}$ Shah of Iran Due in U. S. to Seek Weapons: Guardian and Protector' An Eye on Grumman Nuclear, New York Times, July 22, 1973.

${ }^{123}$ Iran to Buy 30 Jetfighters: Total Cost of the Grumman Planes Is $\$ 900$-Million. Special to The New York Times, New York Times, January 11, 1974.
} 
"destined to become one of the five great powers of the world by 1983") was hardly reassuring for the Americans. ${ }^{124}$

In the early 1970s the Shah became even more vocally concerned over an allimportant question for Iran: What, in operational terms, did the special relationship between Iran and the United States mean and to what extent did Washington appreciate Iran's uniqueness and indispensability? The issue assumed core strategic status in late June 1973 when the United States and the USSR signed the Agreement on the Prevention of Nuclear War. Especially troubling to Tehran was Article II of the Agreement where Washington and Moscow agreed to "refrain from the threat or use of force against the other Party, against the allies of the other Party and against other countries, in circumstances which may endanger international peace and security." ${ }^{125}$ Tehran, on pins and needles over whether it belonged to the "ally" or "other countries" category within the agreement, tasked foreign minister Abbas-Ali Khalatbari to inquire Secretary of State William Rogers and National Security Advisor Kissinger on the exact meaning and implications of Article II and seek the US government's public or private clarification and reassurance on the matter. ${ }^{126}$ After much contemplation, Washington decided to remain ambiguous on Iran and CENTO's placement within the agreement. This was, as

\footnotetext{
${ }^{124}$ A Napoleonic vision of Iran as a new Japan: Shah of Shahs, Shah of Dreams Shah of Shahs By David Holden, New York Times, May 26, 1974.

${ }^{125}$ Agreement Between The United States of America and The Union of Soviet Socialist Republics on the Prevention of Nuclear War. US Department of State. Bureau of International Security and Nonproliferation http://www.state.gov/t/isn/5186.htm (Accessed June 12, 2011).

${ }^{126}$ Secret Sensitive. From Secretary of State to Ambassador Tehran. Meaning of Article II of US-Soviet Agreement on Prevention of Nuclear War. June 29, 1973. Box 1027 Presidential-HAK Memcons -Memcons April-Nov 1973. July 27, 1973. National Security Council Files. Mandatory Review Documents, College Park, MD.
} 
far as the Shah was concerned, a clear signal that the US was not prepared to extend unequivocal NATO-esque assurances to Tehran.

The irritated Monarch decided to push the issue again in his visit to Washington a month later. In a July 1973 conversation with Henry Kissinger, the Shah reiterated "that Iran should not be looked at as just another Middle Eastern country" confident in the fact that "in 5-10 years time, it will be very different and will stand out from its neighbors." He conveyed with his characteristic aplomb the same sentiment to the Soviet ambassador to Iran calling on the superpower to the North to treat Iran "the same as other big countries in the world." Elaborating on this theme to Henry Kissinger, he went on to claim, "what is important is for the Russians to understand that we are not afraid of fighting them."127 Excessively self-confident, HIM also warned his American audience that the U.S. could descend into anarchy and "move from a first-rate power to a fifth or even a tenth-rate power." When the issue of Iran's arms procurement came up, the Shah, emphasized the fact that "he knew what he was doing" and reminded Dr. Kissinger he had "a friend in the U.S. that was ready to provide anything he needed --short of atomic weapons and they are not an issue." 128

These allusions by HIM to Iran's "indispensible" past and prospective contributions toward the United States' interests in the Persian Gulf were recurring themes in Iran-US relations whose initial signs one could trace back to the earl 1970s. The rather hyperbolic assertions as to Tehran's entitlement to the strategic rewards of the

\footnotetext{
${ }^{127}$ Top Secret. Memcon between Shah of Iran, Kissinger, and Helms. Box 1027 Presidential-HAK Memcons -- Memcons April-Nov 1973. July 27, 1973. National Security Council Files. Mandatory Review Documents, College Park, MD.

${ }^{128}$ Top Secret. Memcon between Shah of Iran, Kissinger, and Helms. Box 1027 Presidential-HAK Memcons -- Memcons April-Nov 1973. July 27, 1973. National Security Council Files. Mandatory Review Documents, College Park, MD.
} 
"special relationship" (if it was genuinely special) did lead the Americans to develop second thoughts as to the Shah's ambitious nuclear program in the mid 1970's. One could safely speculate that getting some leeway and latitude on the nuclear issue was on the Shah's mind as Tehran was pushing against the boundaries of the special relationship to see how much nuclear diversion it could get away with. Gary Sick, a veteran observer of Iran who served on the U.S. National Security Council under Presidents Ford and Carter, believed that the United States was highly unlikely to extend the "Israel treatment" to the Shah on the issue of nuclear weaponization. ${ }^{129}$

Of course, as we will see in the next chapter, with the Carter administration coming to power, the Shah, much to his chagrin, found out that his room for maneuver was not as expansive as he thought on the nuclear issue as the Iranians and Americans came to loggerheads on the issue of reprocessing. The United States' denial to grant Iran the "Israel treatment" in the nuclear field came as a rather shocking realization for HIM reminding the Monarch that Tehran's indispensability in U.S. strategic thinking was more circumstantially, than directly (like Israel's) driven and was therefore prone to reprioritization should the atmospherics of the Cold War radically transform.

These were early indicators that the Shah was thinking big on the nuclear issue and if the Shah's nuclear enterprise was not explicitly identified and designated as a "proliferation threat", it was under the de-securitizing pressures at the international level where Washington couldn't simply run the risk of alienating its key ally in the Middle East. In other words, all the elements for legitimately securitizing the INP under the Shah were there only lying fallow as their articulation and designation in proliferation threat terms would require operational imperatives that would go against the thrust of the more

\footnotetext{
${ }^{129}$ Interview with the author, July 29, 2010.
} 
urgent and macro securitization between the international archrivals. After the 1979 revolution and once that indispensability element was eliminated, even more so after the implosion of the Soviet Union in 1991, once the systemic level pressures were gone, the Iranian nuclear program came under massive securitization and gradually assumed a central position in the threat package the United States assembled against the Islamic Republic. 


\section{CHAPTER 3}

\section{4-1978: NUCLEAR EXUBERANCE}

The years from the establishment of the Iran Atomic Energy Organization (IAEO) in March 1974 until the heady months of late 1978 mark the golden age of Iran's atomic program. This was an era when the state's elite bubbled with nuclear enthusiasm and the program picked up operational and, concomitant with that, visionary and futuristic steam.

In this period windfall revenues generated by the 1973 oil bonanza coupled with atmospherically amicable ties to the Western bloc made for unprecedentedly ideal material and normative platforms for the Shah to push through with a grandiose nuclear enterprise.

In this period, an all-important bureaucratic layer was established and added to the INP and a remarkable socio-cultural engineering campaign was launched to wean the Iranian bureaucracy and public off of an oil-dominated energy policy re-gearing it toward a genuine appreciation for the cutting-edge nuclear technology. One can hardly overstate the impact of Swiss-trained nuclear scientist Akbar Etemad in shaping and orienting the INP in this era. As a matter of fact, it was Etemad who took upon himself the responsibility of educating His Imperial Majesty into the world of the atom and the sociopolitical and bureaucratic imperatives of establishing a visionary and truly national nuclear program.

In an era in Iran's nuclear journey probably best characterized as the institutionalization period of the INP, Akbar Etemad who, in no small part, thanks to a lack of personally entrenched ties to either the United States or Great Britain, ran the AEOI as independently of great power politics as feasible. An almost puritanically 
nationalistic figure, Etemad made the devising of an indigenous capacity on all matters nuclear a top strategic priority. One might go so far as to claim that the roadmap Etemad chartered for the INP created a path dependency along which Iran's nuclear program evolved even after the 1979 tectonic shifts in the political configuration of power in Tehran. One wonders what an Islamic Republic nuclear program would have looked like had the Shah not gotten the enterprise off the ground in that particular direction.

Apart from that, in this era one could also detect the initial signs of the intertwinement of a nuclear capability with national security imperatives in the Shah's long-term calculations. The links are especially poignant within the context of India's "peaceful nuclear explosion" of May 1974, a monumental event that exercised an indelible atmospheric impact on the gravitation of INP towards security thinking in these years.

\section{Establishment of the AEOI and the Indian PNE}

In early March 1974, Reza Ghotbi, the Queen's cousin and the head of Iran's National Radio and Television Organization, informed Etemad that the Shah, unhappy with the lethargic pace and rudderless movement of Iran's nuclear projects, had made a final determination to get the ball rolling on a massive atomic program and was contemplating putting Etemad at the helm. In a preliminary meeting, the Shah tasked Etemad with charting a roadmap for Iran's nuclear energy program within two weeks. In a follow-up meeting, Etemad gave HIM a fifteen-page concept paper that laid out the broad contours and overall trajectory of a national nuclear enterprise for Iran. The Shah 
went through Etemad's proposed plan a few times and approved it on the spot as the country’s strategic nuclear document. ${ }^{130}$

Following that meeting between Etemad, Hoveyda, and the Shah, on March 9, 1974 in an imperial decree addressed to Prime Minister Hoveyda, HIM ordered the creation of the Atomic Energy Organization of Iran (AEOI):

"In view of the importance that we attach to the utilization of nuclear power in the country's industrial and agricultural development programs, under this firman (decree) the government is duty bound to set up organizations which will establish coordination and supervision over all matters pertaining to the use of nuclear power as well as in the construction of nuclear power generators and desalinization plants and in preparing the necessary scientific and technical infrastructure necessary to implement these projects.

We also stipulate that Mr. Akbar Etemad be assigned to prepare the organization and the duties of this establishment, in a maximum period of 1 month, to be implemented upon approval.

Because of the importance of the matter, these organizations will carry out their duties under our direct supervision.

Niavaran Palace Esfand 18, 1352 (March 9, 1974). "'131

\footnotetext{
${ }^{130}$ Abbas Milani, Eminent Persians: The Men and Women Who Made Modern Iran, 1941-1979 (Syracuse , NY: Syracuse University Press, 2008). See also Akbar Etemad, Barnameh-ye enerji-ye atomi-ye iran, talash-ha va tanesh-haa (Iran's Nuclear Energy Program, Hopes and Challenges), ed. Gholam Reza Afkhami (Bethesda, MD: Bonyad-e Motale'at-e Iran (Foundation for Iranisn Studies), 1997) P 14.

${ }^{131}$ Foreign Broadcast Information Service (FBIS) Daily Reports, Teheran Domestic Service, 1974-03-17, Shah Issues Decree On Nuclear Power Organization http://docs.newsbank.com/s/HistArchive/fbisdoc/FBISX/12AE4C2368ED6AC0/0D0CB4F6C367F64A (Accessed July 18, 2011).
} 
Following the decree and leaving no doubts on the significance he attached to the nuclear issue, in his address to the nation on the occasion of the Iranian New Year $\left(\right.$ March $\left.21^{\text {st }}\right)$, the Shah reiterated the importance of atomic energy and promised that Iran would "enter the era of utilizing nuclear energy ... as soon as possible so that the consumption of oil, this vital and exhaustible material whose nobility we have been able to prove, is reduced to a minimum and so that this precious substance can be used to produce chemical and petrochemical products instead of being used as ordinary fuel." ${ }^{132}$

The AEOI had a unique inception in that its establishment as an autonomous organization in March 1974 was consummated by an imperial decree. What made the organization even more an object of curiosity was its rather "unusual authority to hire staff" unencumbered by the Iranian bureaucracy's established $\operatorname{SOPs}^{133}$ and the unprecedented latitude it was granted to jumpstart a massive nuclear enterprise encompassing functions as wide-ranging as generating electricity, nuclear $\mathrm{R} \& \mathrm{D}$, international nuclear diplomacy, nuclear technology, and human resource training. ${ }^{134}$ The exponential soar in the AEOI's official budget from hardly over \$30 million in 1975 to

\footnotetext{
${ }^{132}$ Foreign Broadcast Information Service (FBIS) Daily Reports, Teheran Domestic Service, March 21, 1974, Shah Addresses Nation on New Year http://docs.newsbank.com/s/HistArchive/fbisdocdoc/FBISX/12ACE8A91C67BA80/0D0CB4F6C367F64A (Accessed July 15, 2011).

${ }^{133}$ The President of the AEOI, although formally designated a Deputy Prime Minister, reported directly to the Shah.

${ }^{134}$ Confidential. Airgram from the US Embassy Tehran to the Department of State. The Atomic Energy Organization of Iran. April 15, 1976. http://www.gwu.edu/ nsarchiv/nukevault/ebb268/doc14a.pdf (Accessed April 14, 2011).
} 
almost $\$ 1.5$ billion in 1976 and about $\$ 3$ billion in 1978 was testimony to the nuclear programs absolute top priority in Iran's hierarchy of national goals. ${ }^{135}$

As touched upon in the previous chapter, the upsurge in demand for nuclear energy as a strategic alternative to oil following the October 1973 Arab oil embargo against the United States and the Netherlands set both the feasibility and necessity conditions for the Shah's nuclear enterprise. The Shah's ubiquitous emphasis on the imperativeness of redirecting Iran's hydrocarbon endowments toward producing high value-added derivatives like petrochemicals defined the political economy of the Shah's civilian nuclear program.

Apparently, left underexplored in the Shah's visionary paradigm was the sustainability of high oil prices to bankroll an extravagant nuclear infrastructure over the long-term and an ambitious reading of the Iranian economy's absorptive capacity for the projected 23000 megawatts of nuclear electricity to be generated by 1994. This figure would essentially amount to some fifty percent of Iran's projected power capacity by that time.

The AEOI director laid out more concretely the extravagant dimensions of Iran's nuclear program in a December 1975 interview with Le Monde: "Iran's power capacity today is in the order of 5,000 MWe, half of which is linked to the [national] grid. Of this, 80 percent is produced by thermal power stations and 20 percent by hydroelectric power stations. In 18 years' time, we want to possess an installed power capacity of 70,000 MWe." Pressed by the befuddled interviewer on the practicability of and the rationale for such a steep surge in power production, Etemad condescendingly intoned, "In terms of

\footnotetext{
${ }^{135}$ Akbar Etemad, Barnameh-ye enerji-ye atomi-ye iran, talash-ha va tanesh-haa (Iran's Nuclear Energy Program, Hopes and Challenges), ed. Gholam Reza Afkhami (Bethesda, MD: Bonyad-e Motale'at-e Iran (Foundation for Iranisn Studies) 1997) P59.
} 
Western norms this development plan does indeed appear unrealistic, but we consider it accessible for several reasons. Our human resources are far from fully mobilized, our finance possibilities are enormous and never before has there been such a political and national will to achieve rapid and continuous industrialization." ${ }^{136}$

A lack of an explicit securitized response by the United States to this ambitious goal later became a theme that the Islamic Republic constantly used as ammunition in response to the nuclear weapons allegations leveled against it by Washington. The Islamic Republic's position was that whereas the issue of Iran's hydrocarbon resources was skated around by Washington and never militated against the Shah's nuclear program, the West constantly trumpeted it as justification for internationally designating and marketing the Islamic Republic's nuclear program as a security threat.

In any event, as Iran's fledgling nuclear industry suffered from a severe lack of trained manpower in 1974, the establishment of the AEOI serendipitously coincided with an available pool of highly experienced nuclear professionals on the market. This came about, Etemad later recounted, as shortly before the establishment of the AEOI there transpired a mass exodus of nuclear scientists from Argentina following the populist Peronist government's academic purge in the early 1970s. The exodus only worsened with fears of "budget cuts or of anti-upper-class terrorism" gripping the nuclear industry under Peron's widow. ${ }^{137}$ Chief among those who left was Rear Admiral Oscar A.

\footnotetext{
${ }^{136}$ Foreign Broadcast Information Service (FBIS) Daily Reports, Pairs Le Monde, December 2, 1975, Le Monde Interviews Iranian Nuclear Energy Official http://docs.newsbank.com/s/HistArchive/fbisdoc/FBISX/11D8BF78E44EC108/0D0CB4F6C367F64A (Accessed July 25, 2011).

${ }^{137}$ George H. Quester, "The Shah and the Bomb," Policy Sciences 8, no. 1 (March 1977): 21-32.
} 
Quihillalt, the director of the Argentine National Atomic Energy Commission $\left(\mathrm{CNEA}^{138}\right)$ for almost two decades (1955-1973) whom Etemad hired in May 1974 at a whopping monthly salary of $\$ 10,000$ to act as senior advisor to the AEOI. ${ }^{139}$ Quihillalt brought with him a handful of former CNEA scientists and technicians that were indispensible in jumpstarting Iran's embryonic nuclear bid.

As a matter of fact, it was Quihillalt and his close associates who constituted the technical and operational core of Iran's nuclear program at this initial phase. In order to maximize the transfer of technical and logistical know-how and create an intimate atmosphere of collaboration, Etemad recalls, three or four Iranian technicians were assigned to work under the supervision of an Argentinean professional. In time, the camaraderie between the two in the AEOI grew so strong that the Argentineans started referring to themselves as Argentine Iranians. ${ }^{140}$

Quihillalt's legacy as a fierce advocate of indigenizing the full spectrum of the nuclear energy cycle in Argentina was hardly a reassuring factor for the U.S. national security elite. The Argentine connection was instrumental in how Tehran's nuclear activities became an object of suspicion for Washington later in the 1970s. Quihillalt's presence in Iran was specifically disconcerting to the Americans since under his directorship, Argentina catapulted itself to the avant-garde of the nuclear industry in Latin America. In 1958, for example, Argentina was the first Latin American country to commission a research reactor. A decade later, in 1968, it was the first nation to operate a

${ }^{138}$ Comisión Nacional de Energía Atómica

${ }^{139}$ Norman Gall, "Atoms for Brazil, Dangers for All ," Bulletin of the Atomic Scientists, June 1976.

${ }^{140}$ Akbar Etemad, Barnameh-ye enerji-ye atomi-ye iran, talash-ha va tanesh-ha (Iran's Nuclear Energy Program, Hopes and Challenges), ed. Gholam Reza Afkhami (Bethesda, MD: Bonyad-e Motale'at-e Iran (Foundation for Iranisn Studies), 1997) P 24. 
pilot chemical reprocessing plant in the region and again in 1974 Latin America's first nuclear power plant was commissioned in Argentina. ${ }^{141}$

\section{The Indian PNE and its Fallout}

As the Shah and his visionary nuclear mastermind Dr. Etemad were meticulously setting the domestic and international stage for the newly founded Atomic Energy Organization of Iran (AEOI) to hit the ground running, the entire architecture of the international nuclear industry was thrown for a loop on May 18, 1974. On this day, India detonated a 12-kiloton plutonium device -rather oxymoronically termed a "peaceful nuclear explosion" (PNE)- in the Rajasthan desert. This development touched off a quantum shift in the tenuous equilibrium of power in South Asia with unmistakable proliferation implications for the Middle East.

The timing of India's PNE couldn't have been worse for Iran as it caused a change of heart in Washington about national nuclear programs and cast a long shadow over the prospects for nuclear cooperation between the United States and Iran. The fact that India used the research reactor provided by Canada and the United States for producing the required fissile material for the PNE marked the beginning of the designation of nationally run full fuel cycles and reprocessing facilities as proliferation threats in successive U.S. administrations from Nixon on. The Indian explosion also incorrigibly stigmatized the Atoms for Peace Program bringing to the fore a host of proliferation pathologies associated with indigenous nuclear efforts.

From this perspective, the coincidence of the establishment of the AEOI with the Indian test was the most fundamental impediment in the way of a nuclear deal between Iran and the United States. This timing factor essentially turned the deal with Iran into a

\footnotetext{
${ }^{141}$ Norman Gall, "Atoms for Brazil, Dangers for all ," Bulletin of the Atomic Scientists, June 1976.
} 
trendsetting and precedent-defining phenomenon for the White House. In other words, even if Washington was willing (and the declassified evidence hardly lends credence to this argument) to give the Shah the benefit of the doubt on proliferation, being at the forefront of the United States' new nuclear export policymaking process following the Indian PNE made the nuclear deal with Iran an impossibly sensitive and thorny issue. On this score, Washington's argument was that cutting the Shah too much slack would make it difficult to demand more stringent control mechanisms elsewhere.

The Nixon Administration's National Security Study Memorandum (NSSM) 202 (imposing additional restrictions on the transfer of nuclear technology, equipment, and fuel to receiving countries) was the immediate manifestation of a drastically changed atmosphere. $^{142}$ Right on the heels of NSSM 202 came National Security Decision Memorandum (NSDM) 255 of June 3, 1974, a watershed document that explicitly securitized national chemical reprocessing and uranium enrichment programs and advocated their replacement by "multinational enrichment, fuel fabrication and reprocessing facilities." 143

Under these changed circumstances, the United States introduced a new policy of enforcing "special bilateral controls" - beyond those required by the IAEA — on transfer of nuclear reactors and fuel. This dramatic policy shift following the Indian explosion was decidedly a departure from NSDM 235 of only a few months earlier (October 1973) when the United States had declared that it would "not require as an essential

\footnotetext{
${ }^{142}$ Secret. National Security Study Memorandum 202, Nuclear Non Proliferation Treaty. May 23, 1974 http://nixon.archives.gov/virtuallibrary/documents/nssm/nssm_202.pdf (Accessed May 17, 2011)

${ }^{143}$ Secret. National Security Decision Memorandum 255. June 3, 1974 http://nixon.archives.gov/virtuallibrary/documents/nsdm/nsdm_255.pdf (Accessed May 17, 2011)
} 
precondition of supply that fuel fabrication and reprocessing take place in the United States or in multi-nationally owned facilities."144

The United States' proposal, however, didn't sit well with the Iranians (This was true especially in the Ford Administration when the concept of multilateral chemical plutonium reprocessing facilities as a mechanism to reduce proliferation risks in instability-prone regions like the Middle East came to the fore). Tehran's core argument against such an arrangement was premised on feasibility and logistical grounds. The Iranians believed that, due to the severe trust deficit between Iran and its periphery in the Persian Gulf, working out the operational requirements of such an enterprise would be a nightmare. Tehran, furthermore, viewed such a multilateral concept as impinging on its national sovereignty rights as, in Iran's judgment, it essentially amounted to depriving Iran of the economic and strategic benefits accruing to stockpiling plutonium on its territory.

Immediately following the Indian explosion, Tehran adopted a declaratory policy of nuclear ambiguity with the Shah's spokesman emphasizing HIM "would have no immediate comment on India's explosion." ${ }^{145}$ Tehran's continued failure to publicly and categorically condemn the Indian explosion gave rise to speculation in Washington that Prime Minister Indira Gandhi "might have told the Shah of the scheduled detonation of a

\footnotetext{
${ }^{144}$ Secret. National Security Decision Memorandum 235. United States Policy on Transfer of Highly Enriched Uranium for Fueling Power Reactors October 4, 1973 Security and Other Aspects of the Growth and Dissemination of Nuclear Power Industries http://nixon.archives.gov/virtuallibrary/documents/nsdm/nsdm_235.pdf (Accessed May 17, 2011)

${ }^{145}$ New York Times, May 30, 1974.
} 
nuclear device" when Tehran and New Delhi concluded a communiqué in Tehran to cooperate in the nuclear field just shortly before the May explosion. ${ }^{146}$

It is important to note that Iran's official position on the issue of nuclear proliferation was less than clear-cut even before the Indian explosion heightened the Shah's anxieties that Tehran was falling behind in the nuclear field. Despite being a signatory to the NPT, Tehran's official position on non-proliferation was that "the issues [related to non-proliferation] will become more and more difficult as time passes, and therefore a universally acceptable agreement should be approved as soon as possible on the basis of the US-USSR proposals. ${ }^{147}$ This statement was a clear indication of a carefully calibrated policy by Tehran to de-emphasize the NPT as a strategic response to the challenge of proliferation in South Asia.

The Indian explosion, however, brought to the boiling point an already simmering strategic competition between Tehran and New Delhi in the Indian Ocean basin. Within this context, remarks by K. Subramaniam, director of the Indian Institute for Defense Studies and Analysis, on the Shah's (and other Middle Eastern countries') military buildup were unmistakably poignant. In his rather condescending remarks, Subramaniam dismissed the notion that the Shah's sophisticated military buildup "in an area where the societies are yet to make their transition into modern age" was simply a reaction to Tehran's legitimate security needs. ${ }^{148}$ Depicting such a conflicting relationship between

\footnotetext{
${ }^{146}$ Iran Negotiates for Nuclear Energy Aid By James F. Clarity Special to The New York Times New York Times; May 27, 1974.

${ }^{147}$ Iran Negotiates for Nuclear Energy Aid By James F. Clarity Special to The New York Times New York Times; May 27, 1974.

${ }^{148}$ Foreign Broadcast Information Service (FBIS) Daily Reports, Delhi Domestic Service, December 31, 1974, Defense Studies Director Views New Military Pressures,
} 
Tehran's security needs and its developmental imperatives by a prominent Indian strategist exactly mirror imaged the Shah's judgment on New Delhi's nuclear explosion which, in HIM judgment, showcased India's striving to punch above its strategic weight at the cost of its people's welfare. ${ }^{149}$

The Shah, on the other hand, partly in resignation to the fact that Iran as a late comer to the nuclear game was bound to trail India and Pakistan for some years to come, redoubled its efforts to procure state-of-the-art conventional military hardware to compensate for Tehran's inferior nuclear status. As part of this policy, he developed a keen interest in putting the Iranian navy in such a formidable position that India's nuclear test wouldn't drastically tip the balance of power in the Indian Ocean. This would foil, in HIM's judgment, New Delhi's efforts to put the Indian Ocean beyond the pale for Tehran. Within this paradigm, one of the primary objectives of the Shah's foreign policy in the early 1970 s was to maintain a permanently projective naval capacity in the Indian Ocean. As an operational component of getting a credible and durable foothold combined with maximum maneuverability in the Indian Ocean, the Shah sought to purchase and incorporate Spruance-class destroyers to the Imperial Iranian Navy (IIN) during his July 1973 trip to Washington. ${ }^{150}$

Whether deliberately or by default, during these years in the mid 1970s, Washington was also embracing of the Shah's conventional build-up concept viewing it

http://docs.newsbank.com/s/HistArchive/fbisdoc/FBISX/11D8D3497909CA98/0D0CB4F6C367F64A (Accessed July 18, 2011).

${ }^{149}$ Unclassified. From American Embassy Paris to Secretary of State Washington, Interview with the Shah June 24, 1974. http://www.gwu.edu/ nsarchiv/nukevault/ebb268/doc01a.pdf (Accessed April 15, 2011).

${ }^{150}$ Top Secret. Memcon between Shah of Iran, Kissinger, and Helms. Box 1027 Presidential-HAK Memcons, Memcons April-Nov 1973, July 27, 1973. National Security Council Files. Mandatory Review Documents, College Park, MD. 
as a strategy to conventionally bribe the unquenchable Monarch away from getting any big nuclear ideas. The notion fit so well into the Shah's military thinking in the mid1970s that it convinced him to put a premium on obtaining conventional supremacy. This vision of the Shah was most cogently expressed at the conclusion of the Imperial Air Force air show on March 14, 1977: "Our army will be nonnuclear and will defend our peace and security. Naturally, a nonnuclear army ought to be much stronger than a nuclear army in both numbers and the quality of equipment."151

Well aware of the Shah's mode of thinking on the issue, in June 1974, a Defense Department official revealed Washington's agreement to sell three Tang-class submarines and six Sprunce class destroyers to the Shah. On top of that, mention was made of tentative plans to sell a small carrier to the Imperial Iranian Navy suitable for amphibious operations. As Tehran didn't have any use for the submarines in the Persian Gulf, the Shah's interest in purchasing them could only be tied to HIM's vision on the Indian Ocean basin as Iran's natural sphere of influence where a Persian balancing act was imperative. In concurrence with HIM's judgment, Washington believed that since both India and Pakistan possessed some submarine capability, their provision to the Shah would be a fitting addition to Iran's naval strength. ${ }^{152}$

It is worth mentioning here that the documents declassified so far do not shed a definitive light on whether the United States consciously viewed and sold the cart blanche it granted the Shah to acquire a formidable conventional capability as a

\footnotetext{
${ }^{151}$ Foreign Broadcast Information Service (FBIS) Daily Reports, Teheran Domestic Service March 14, 1977, Shah Comments to Newsmen on Role of Army, http://docs.newsbank.com/s/HistArchive/fbisdoc/FBISX/11D8501530969940/0D0CB4F6C367F64A (Accessed July 24, 2011).

${ }^{152}$ U.S. Plans to Sell 3 Submarines To Iran for Use in Indian Ocean, John Finney, Special to The New York Times. New York Times Jun 10, 1975.
} 
dissuasive mechanism to hedge against the Shah's potential nuclear weapons ambitions. Such an inside logic in Washington is not far-fetched, however, considering the fact that the United States pursued such a strategy vis-à-vis Israel in the 1970 s. ${ }^{153}$ As a matter of fact, in 1976 the International Institute for Strategic Studies (IISS), a prestigious UK based think-tank, floated the idea that the United States' proliferation concerns could be manipulated by countries like Iran to extract non-nuclear concessions in other issue areas. According to this analysis, these weaponization concerns could potentially "enhance the risk that" for countries like South Africa, Israel, Pakistan, Iran, and Turkey, "a minimal nuclear option might become attractive, not for reasons of military security but as a lever to bargain for American concessions in non-nuclear fields, particularly over the supply of conventional arms."

But it is also equally plausible to argue that Tehran's evidently insatiable thirst for conventional armaments might have had an intensifying impact on the threat designation of its equally ambitious nuclear program. From this perspective, one could argue that the military dividends of Iran's nuclear program were contextualized within the broader theme of its enthusiastic bid for "supremacy" - a cherished term in HIM's strategy nomenclature - in the Persian Gulf and ultimately in the Indian Ocean. ${ }^{155}$ Having a

\footnotetext{
${ }^{153}$ Matthew Kroenig, Exporting the Bomb, Technology Transfer and the Spread of Nuclear Weapons (Ithaca, NY: Cornell University Press, 2010) p79.

${ }^{154}$ International Institute for Strategic Studies, Strategic Survey 1976. Quoted in Zdenek Cervenka \& Barbara Rogers, The Nuclear Axis: Secret Collaboration Between West Germany and South Africa (New York, NY: Times Books, 1978).

${ }^{155}$ In his 1972 speech at the Imperial Navy Base, the Shah said: "Events in the world have taught us that the sea contiguous to the Gulf of Oman and I mean the Indian Ocean, recognizes no frontier. ...We are thinking of Iran's security perimeter and I am not speaking in terms of a few kilometers... the navy would be able to assume its new responsibilities only by increasing its ability to strike against any enemy and win in a wide radius." Kayhan International, September 11, 1972. Quoted in Anne Hessing Cahn, "Determinants of the Nuclear Option: The Case of Iran," in Nuclear Proliferation and the Near-Nuclear Countries (Cambridge, MA: Ballinger Publishing Company, 1975) Pp 201-202.
} 
nuclear capacity would, from this viewpoint, broaden Iran's maneuverability and powerprojection perimeter by ensuring - through nuclear deterrence-- its homeland security.

Just to give some sense of perspective to the latter point, according to one expert, "unless other nations engage in similar military buildups, when the Shah's orders of F$14 \mathrm{~s}$, attack helicopters, antisubmarine reconnaissance aircraft, tanker aircraft, destroyers, TOWs, Mavericks, Hawks, Tigercats, Rapiers, and Sidewinders are in inventory, Iran will be one of the ranking conventional military powers in the world." Within such a context, even if Washington's private strategic thinking was one of dis-incentivzing Iran toward the nuclear option by rendering such a capability cumbersome and redundant through giving HIM a carte blanche to buy conventional weapons, the regional narrative might have been one that placed Tehran's civilian nuclear program within a broader military-strategic context.

In this regards and as we will see in the following pages, the Shah's remarkable success in securing conventional armaments from the U.S. also had a deleterious impact on the conclusion of a comprehensive Nuclear Agreement between the US and Iran as it further spooked and antagonized an already alarmist anti-Shah U.S. Congress.

\section{The First Proliferation Red Flags Emerge}

The Shah's (purportedly misquoted) statements just a few weeks after the Indian explosion gave even more credibility to fears in Washington that a nuclear arms race between Iran and India might be rapidly unfolding. Pressed on the question of whether Iran would go nuclear in the future, the Shah, allegedly in some off-the-cuff remarks, quipped, "certainly, and sooner than is believed, but contrary to India, we have first thought of our people and then of technology." Although these remarks were later 
categorically retracted and denied by the Iranian embassy in Paris, their impact on the designation of Iran as a proliferation threat down the road were undeniable. During the same interview with the French weekly Les Informations, on June 23, 1974 the Shah referred to his sophisticated military machinery and his ambitious future plans to advance it as a "force de dissuasion et de frappe." ${ }^{156}$ To some apprehensive observers, the deterrent connotations of the phrase clearly betrayed a Shah harboring nuclear capability ambitions. To heighten Washington's consternation even further, in a later interview broadcast on French TV, a visibly irritated Shah took to task the notion that it was "totally normal" for countries like Great Britain to possess nuclear weapons while “automatically" enjoying NATO's protective nuclear umbrella whereas a strategically lonely Iran's right to self defense was viciously being touted as problematic. ${ }^{157}$

Shortly afterward, the Shah's interview with Le Monde during his state visit to France didn't help dispel or assuage concerns either. This time around, the Shah pointedly declared that if small Middle Eastern countries embarked on a nuclearization path, no matter how primitive or crude, then Iran's "national interests" would compel it to follow suit. ${ }^{158}$

Following these remarks, in an immediate cable to the Secretary of State, the U.S. Ambassador to Tehran and former Director of National Intelligence (DCI), Richard Helms, commented that the Shah had Egypt and Israel in mind when referring to other

\footnotetext{
${ }^{156}$ Unclassified. From American Embassy Paris to Secretary of State Washington, Interview with the Shah June 24, 1974. http://www.gwu.edu/ nsarchiv/nukevault/ebb268/doc01a.pdf (Accessed April 15, 2011).

${ }^{157}$ Shah of Iran on Nuclear Weapons http://www.youtube.com/watch?v=uiUQO7wgcyw (Accessed February 18, 2011).

${ }^{158}$ Unclassified. From American Embassy Paris to Secretary of State Washington. Further Remarks by the Shah on Nuclear Weapons June 25, 1974 http://www.gwu.edu/ nsarchiv/nukevault/ebb268/doc01b.pdf (Accessed April 15, 2011).
} 
countries' nuclear behavior. ${ }^{159}$ Israel seemed to be the most credible referent object in the caveat clause of the Shah's speech as HIM specified "little" countries in the region. As is evident, the external circumstances were not helping curb the Shah's nuclear appetite.

In this connection, it is also worth remembering that in 1974 Iran was aware of Israel's capability to make the atomic bomb as in December 1974 Israeli President Ephraim Katzir went public, for the first time, with his country's possession of nuclear weapons know-how. ${ }^{160}$ Furthermore, a few days before these statements by the Shah, on June 14 1974, President Nixon and President Sadat had signed an agreement entitled "Principles of Relations and Cooperation between Egypt and the United States" that provided for Washington to supply Cairo with nuclear reactors and fuel. ${ }^{161}$

These major developments seem to have injected a sense of urgency in the Shah that Iran was lagging behind in the nuclear field and had to, rhetorically at least, play catch up. This was part of HIM's reasoning to refrain from categorically ruling out the nuclear option in Iran's security paradigm in his multiple interviews after the Indian explosion where His Imperial Majesty chose to keep the United States guessing by linking up Tehran's non-proliferation posture to the continuation of the status quo in the Middle East's strategic environment. This was a decision that infinitely compounded Washington's proliferation apprehensions. Following the Indian explosion, in the U.S.

\footnotetext{
${ }^{159}$ Unclassified. From American Embassy Tehran to Secretary of State Washington Immediate. June 25, 1974 Shah's Alleged Statement on Nuclear Weapons. http://www.gwu.edu/ nsarchiv/nukevault/ebb268/doc01c.pdf (Accessed April 17, 2011).

${ }^{160}$ NBC Evening News for Monday, Dec 02, 1974. Record Number: 474736 Television News Archive. Nashville, Tennessee. Television News Archive, Vanderbilt University. http://tvnews.vanderbilt.edu/program.pl?ID=474736 (Accessed May 4, 2011).
}

\footnotetext{
${ }^{161}$ Anwar Sadat Archives. Summits and Peace Agreements, http://sadat.umd.edu/archives/summits.htm (Accessed April 12, 2011).
} 
intelligence community's judgment, Iran was "likely to reassess the recent warming of its relations with India" in light of the fact that the Shah was "determined to develop Iran into the region's paramount power, and was probably miffed at having been upstaged by India." From this perspective, the Indian test would further accelerate Tehran's quest for nuclear energy facilities in Iran. ${ }^{162}$

It is also worth mentioning that lurking beneath Iran's heightened threat perceptions in the wake of India's explosion was an opportunistic desire by the Shah to get maximum mileage out of an air of nuclear inevitability created by India. For instance, in a joint communiqué issued at the end of the Shah's visit to India on October 4, 1974, the two sides made a point of emphasizing the "importance of insuring that access to nuclear technology is not confined to a few countries" underlining its implications for economic development and human welfare." 163

The international community's, with the exception of Canada and the U.S., fairly tolerant and lenient response to India's 1974 explosion was also another factor in accentuating the United States' worst fears that countries like Iran would push against the boundaries of the non-proliferation regime in a tightly bipolar international system to see how much nuclear adventurism they could get away with. France, Iran's main nuclear partner during the mid 1970s was at the forefront of Washington's countries of concern

\footnotetext{
${ }^{162}$ Top Secret. The National Intelligence Daily. Director of Central Intelligence. India's Nuclear Test: Worldwide Reverberations. May 21, 1974, http://www.foia.cia.gov/docs/DOC_0000845828/DOC_0000845828.pdf (Accessed April 18, 2011).

${ }^{163}$ Text of Communiqué on Visit by Shah of Iran, Foreign Broadcast Information Service (FBIS) Daily Reports, Delhi Domestic Service, October 4, 1974 http://docs.newsbank.com/s/HistArchive/fbisdoc/FBISX/11E04EA1E5E59578/0D0CB4F6C367F64A (Accessed July 14, 2011).
} 
about the transfer of proliferation-prone technology to Third World countries in exchange for financial gains.

It was within such context that the United States came to internalize the inadequacy, unenforceability and potential credulity of the IAEA safeguards and the NPT commitments as counter-proliferation measures. The intelligence community was specifically concerned that these international contractual mechanisms would fall short either in detecting clandestine diversion of nuclear materials and equipment or in dissuading "any state bent on developing a weapon." Thus viewed, in Washington's judgment, this shortcoming coupled with the French and German governments' subpar commitment to prioritizing their non-proliferation interests over their commercial and political gains made for a permissive, if not promiscuous, proliferation environment in the international system. ${ }^{164}$

In such an atmosphere in mid-1974 and as the securitizing factors were piling up on Iran's nascent nuclear program, the Shah made a determination to take the lead, along with Egypt, in initiating the idea of establishing a Nuclear Weapons Free Zone (NWFZ) in the Middle East. As part of this de-securitizing posture, on July 13, 1974, Tehran made a request to the UN General Assembly (UNGA) to take up an item entitled "Establishment of a Nuclear-Free Zone in the Region of the Middle East." The conventional wisdom at the time was that the Shah had a broadly-conceived notion of the term Middle East that included Pakistan, Turkey, and Egypt whom Tehran feared were

\footnotetext{
${ }^{164}$ Secret. National Intelligence Council Memorandum. The Dynamics of Nuclear Proliferation: Balance of Incentives and Constraints. September 1985. www.foia.cia.gov/docs/DOC_0000453458/DOC_0000453458.pdf (Accessed July 14, 2011).
} 
predisposed to make a run for the bomb following the Indian explosion. ${ }^{165}$ It is worth mentioning here that although Iran had made the original proposal in 1968 for the international community to recognize the Middle East as a nuclear-free zone, in the hectic circumstances surrounding the 1967 Arab-Israeli war, it was not put on the UNGA agenda. Despite its lack of substantial traction, as State Department documents demonstrate, this initiative had some moderate impact in ameliorating the United States' worst proliferation fears especially following the controversy over HIM's remarks in Paris on June 23, 1974.

On a more pragmatic level, Iran's advocacy of the NWFZ idea also fell well in line with the argument marshaled by nuclear pundits as a possible determinant holding in check Iran's proliferation desires. This line of thinking was essentially based on the strategic imprudence of initiating a potentially game-changing nuclear arms race by a country of considerable strategic depth and conventional superiority. From this perspective, considering the "equalizing" function of nukes in neutralizing conventional quantitative and qualitative power relativities, it would be self-defeating for Tehran to nuclearize its strategic environment, as it would trigger a proliferation domino effect in Iraq, Turkey, and Saudi Arabia. ${ }^{166}$

\section{Tehran's Nuclear Standoff with Washington}

As previously touched upon, despite Tehran's high hopes and keen interest in securing maximum nuclear cooperation from the United States, the fallout of the Indian

\footnotetext{
${ }^{165}$ Iran Asks U.N. Action to Keep Region Free of Nuclear Arms: Earlier Ban Suggested India Test, By Kathleen Teltsch, Special to The New York Times, New York Times; Jul 13, 1974.

${ }^{166}$ Anne Hessing Cahn, "Determinants of the Nuclear Option: The Case of Iran ," in Nuclear Proliferation and the Near-Nuclear Countries (Cambridge, MA: Ballinger Publishing Company, 1975) P 195.
} 
explosion nipped, for all practical purposes, its materialization in the bud. This situation was in stark contrast with the prevailing atmosphere in Western Europe where Iran made fairly smooth and long strides in securing both nuclear hardware and software acquisitions. As the Shah attached infinitely more strategic weight to nuclear partnership with the United States though, however, the standoff with Washington incrementally turned into the litmus test of the resilience and profundity of the latter's commitment to Tehran as an indispensible ally.

Following the Indian explosion, a major impediment in the way of finalizing a strategic nuclear cooperation document between Tehran and Washington was the United States' dogged insistence on long-term sole source fuel contracts with the U.S., disposition of plutonium, and physical security. The United States' new position was based on a new policy of enforcing "special bilateral controls" - beyond those required by the IAEA —on transfer of nuclear reactors and fuel. These new requirements were diametrically opposed to Etemad's insistence on Iran having full command \& control over its indigenously enriched and processed fissile material.

Although Washington initially played with the idea of settling only for IAEA safeguards and the NPT obligations as satisfactory counter-proliferation measures, a host of second thoughts, partly associated with the high concentration of power in Iran and transition of power contingencies associated with Iran's political system quickly kicked in. These apprehensions emanated from HIM's peculiar decision-making style that betrayed a deteriorating "Super Shah syndrome," and its accompanying "invincibility" delusions. ${ }^{167}$

\footnotetext{
${ }^{167}$ Mohsen Milani, The Making of Iran's Islamic Revolution: from Monarchy to Islamic Republic, (Boulder, CO: Westview Press, 1994).
} 
For instance, according to a June 1974 State Department Internal Memorandum, "Although Iran is a currently stable, that stability is heavily dependent on the Shah's remaining in power. In a situation of instability, domestic dissidents or foreign terrorists might easily be able to size any special nuclear materials stored in Iran for use in bombs.... An aggressive successor to the Shah might consider nuclear weapons the final item needed to establish Iran's complete military dominance of the region."168

Washington's concerns with the stylistics of the Shah's mode of governance were even more candidly articulated in the mainstream U.S. media. For instance, a 1974 Newsweek article quoted a Washington strategist warning the United States against creating a "Frankenstein monster" that would prove an unstablizing force "with his egomania and his expansionist vision of the revival of ancient Persia's power."169

It is worth remembering that the United States' concern with the stylistics of the Shah's rule as a potential source of uncertainty and instability and an obstacle for a smooth transition of power went back at least to the mid-1960s. A 1966 State Department cable, for instance, reads: "Despite the fact that the Shah is presently riding tall in the saddle serious weaknesses remain on the Iranian scene. The Shah's life continues to be at the mercy of the fanatic or disgruntled who may be prepared to give his life to eliminate the Iranian ruler. This, of course, is an internal security threat by no means peculiar to Iran. However, the narrowness of the political base in Iran renders this threat more acute than in other countries enjoying a broader base of political support and greater prospects

\footnotetext{
${ }^{168}$ Confidential. Internal Department of State Draft Memorandum. June 20, 1974 enclosed in Confidential. Office of Assistant Secretary of Defense for International Security Affairs to Secretary of Defense, "Nuclear Energy Cooperation with Iran (U) - Action Memorandum," June 1974. http://www.gwu.edu/ nsarchiv/nukevault/ebb268/doc02.pdf (Accessed May 4, 2011).
}

${ }^{169}$ Quoted in John Abbott, The Iranians: How They Live and Work (New York, NY: Praeger, 1977). P67. 
for an effective follow-on-government." ${ }^{170}$ Under these atmospherics, as the symptoms of popular discontent grew visible in 1977, Washington grew even more apprehensive of the prospect of a sophisticated nuclear infrastructure in a country in imminent danger of regime-change with anti-Western Islamists pounding on the door.

Well aware of these domestic uncertainties in Iran and mounting anti-Shah sentiments on the home front, the Nixon Administration came to the position that only an agreement along the lines concluded with Egypt and Israel, which had made allowances for additional safeguardability beyond the IAEA and NPT mechanisms, stood a realistic chance of passage through a U.S. Congress increasingly leery of Iran's sable-rattling and the Shah's military extravaganza in the Persian Gulf. Iran, adamant about having indigenous reprocessing capacity, vehemently opposed the special safeguards stipulation partly on the grounds that Tehran, while a member in good standing of the NPT, was essentially being (mis)treated as a non-member.

It should be noted here that the implications of this last point apply equally to both the Shah and the Islamic Republic era and have to do with differing modes of interpreting the NPT between Iran and the United States. Put simply, Washington, as the progenitor and custodian of the international non-proliferation regime, viewed the NPT commitments of member states as constituting only a bare minimum mechanism to establish the country's non-proliferation credentials -hence in need of being reinforced and fortified through auxiliary reinsuring measures like bilateral safeguards agreements and the Nuclear Suppliers Group (NSG). From Iran's perspective, however, NPT membership denoted a clean bill of health on the signatory's nuclear activities whose

\footnotetext{
${ }^{170}$ Confidential. Airgram, Department of State. Prospects for the Military Assistance Program in Iran. January 3, 1966. RG 59 General Records of the Department of State General Foreign Policy Files 1964-66 Political \& Defense Box 1733. National Archives at College Park, College Park, MD.
} 
bona fides shouldn't be constantly second guessed. But the reality of the situation was that not only was the United States impossibly reluctant to put the Shah on a long nuclear leash, it was not even fully willing to grant Iran the indigenous fuel-cycle privileges that were completely within its NPT rights.

At a time when Iran was bending backwards to wean itself from oil and move toward the atom to meet its industrial electricity demands, in Etemad's assessment, denial of these rights to Iran was tantamount to a breach of Nuclear Weapons States' NPT obligations under Article IV of the treaty. ${ }^{171}$ Etemad believed that the imposition of rigorous extra-NPT control mechanisms blurred the difference between civilian and military nuclear technologies that lay at the very foundation of the bargaining between nuclear haves and have-nots that roped the latter into the NPT regime in the first place. ${ }^{172}$ Etemad's reasoning for Iran's go-it-alone philosophy on the fuel cycle was that Iran couldn't afford to be held hostage to any foreign country for its fuel requirements and live with that vulnerability since any reneging by the foreign supplier on its contracts would render Iran's nuclear investment and infrastructure operationally useless.

This rationale of Etemad was not entirely lost on the Americans either. In point of fact, numerous State Department cables drew the Ford Administration's attention to the inherent incompatibility, both in spirit and substance, between pursuing draconian extra-

\footnotetext{
${ }^{171}$ This article spells out the inalienable right of signatory countries to have access to peaceful nuclear technology and materials.

${ }^{172}$ Akbar Etemad, Barnameh-ye enerji-ye atomi-ye iran, talash-ha va tanesh-haa (Iran's Nuclear Energy Program, Hopes and Challenges), ed. Gholam Reza Afkhami (Bethesda, MD: Bonyad-e Motale'at-e Iran (Foundation for Iranisn Studies) 1997). Pp 135-150.
} 
NPT restrictions across the board and championing universal membership for the embattled treaty. ${ }^{173}$

Additionally, the Shah believed that, due to its domestic stability and its pivotal position in stabilizing the Middle East, Iran shouldn't be treated like Egypt and Israel, countries that in HIM's judgment, were trouble spots and potential sources of instability. Put simply, from the Shah's perspective, lumping Iran together with Israel and Egypt in the same category was Washington's way of saying that Iran was not a mature state. As far as HIM was concerned, nothing could be farther from the truth.

On the basis of these realities, the Shah was unyielding about his demands to receive "preferential treatment" in technology and fuel supply. Such a treatment would essentially exclude the additional stringent measures the United States had included in its agreements with non-NPT member states like Israel and Egypt. These measures included "reprocessing, fabrication and storage of U.S. material and plutonium produced from the use of U.S. supplied material or equipment outside the [recipient] country; offering the U.S. first option to "buy back" produced plutonium; the provision of mutually agreed physical security measures; expressed confirmation that the recipient would not use U.S. material for PNEs and that all future nuclear material and facilities entering the country would be subject to IAEA safeguards."174

Over almost four years of intense negotiations with Iran (that practically made Iran part of the legislative debates leading to the Jimmy Carter's Nuclear Non-

\footnotetext{
${ }^{173}$ See, for example, Secret. Report of the NSSM 219 Working Group Nuclear Cooperation Agreement with Iran. April 1975. http://www.gwu.edu/ nsarchiv/nukevault/ebb268/doc05a.pdf (Accessed July 17, 2010).

${ }^{174}$ Confidential. From New-Alfred L. Atherton, Jr. OES/ Nelson F. Sievering Jr. to Secretary of State. Nuclear Energy Agreement for Cooperation with Iran. December 6, 1974 http://www.gwu.edu/ nsarchiv/nukevault/ebb268/doc04.pdf (Accessed July 16, 2010).
} 
Proliferation Act of 1978), the United States envisaged four possible scenarios in striking a nuclear deal with Iran. The first and least favored option by Washington was to conclude a civilian nuclear deal without any additional controls on top of those imposed through the NPT and IAEA mechanisms. Washington reasoned that the option, referred to as the standard agreement, would have the great merit of rewarding the Shah's adherence to those two non-proliferation regimes while not discrediting their efficiency by imposing additional restrictions. Concluding an agreement along those lines would essentially grant Iran the "most favored nation" status on a par with Japan and Western European states, a privilege HIM deemed Iran was fully deserving of in light of its "special relationship" with the United States.

The State Department's reasoning against this option, however, was based on three grounds. For one thing, being ill-timed, on the bureaucratic front, such an agreement had only minimum chance of passage through an alarmist Congress without some serious and potentially time-consuming arms wrestling. Furthermore, on "substantive" grounds, such a deal would expose U.S supplied technology and fuel supply to a slew of potential risk situations, not least among them diversion, sabotage, terrorism, theft, and regime change. Last, Washington was nervous that the Shah's commitment to Iran's NPT obligations was not ironclad and irreversible and, when push came to shove, His Imperial Majesty might decide to reverse course and pull out of the NPT.

The second scenario consisted of concluding an agreement within the parameters set by the IAEA safeguards and the NPT commitments with the bare minimum of additional "physical protection" controls. Although this via-media option, the State 
Department argued, stood a fighting chance of clearing a gun-shy and foot-dragging Congress, it would not alleviate the Shah's ever mounting suspicions that Iran was being "singled out" by receiving subpar and double-standard treatment.

The third scenario, most favored by the Department of State and the Atomic Energy Commission, fell between the first two scenarios. According to this option, the United States would have "veto rights over reprocessing, fabrication, and storage of U.S. material and plutonium produced from the use of U.S. supplied material or equipment." This option would modify the one-size-fits-all approach of subjecting all the future nuclear agreements to the stringent and sweeping cautionary measures applied to Israel and Egypt, both non-signatory to the NPT at the time, and reward Iran's NPT membership by not requiring the external disposition of plutonium as required of Egypt and Israel. It is interesting to note, however, that the U.S. State Department thought even the veto rights incorporated in the third scenario were inadequate in finalizing the nuclear deal with the Shah. State officials' rationale was that the physical presence of plutonium on Iranian territory constituted a potential proliferation risk. In the State Department's judgment, this option only stood a minimum chance of receiving the Shah's blessing as HIM would interpret veto rights as discriminatory, infringing upon Iran's sovereignty and dignity, and running afoul of the spirit of Iran's relations with the United States.

The fourth option entertained by the United States was one of subjecting Iran to the same maximalist and proliferation-proof standards imposed on Israel and Egypt. Although this option, the Americans argued, would be ideal in placating proliferation concerns of the Congress, it had its own major drawbacks: for one thing, it would have a detrimental atmospheric impact on the credibility of the international non-proliferation 
regime on the eve of the First NPT Review Conference in May 1975. The thrust of the argument was that, if the United States failed to offer "preferential treatment" to the NPT signatories like Iran, it would deal a paralyzing blow to the incentive mechanisms envisioned and enshrined in the NPT to consolidate the treaty into the cornerstone of an all-inclusive universal non-proliferation regime. For another, the State Department reasoned, the Shah would find "especially onerous" the explicit preclusion of any reprocessing, storage, and fabrication involvement by Iran in the U.S. supplied fuel and technology. ${ }^{175}$

The very existence of such wide-ranging scenarios was testimony to massive chasms in the US government on how best to cope with the nuclear wishes of a major ally constantly knocking on the door. The time constraints imposed on the situation-with an anxious AEOI chomping at the bit to cut a deal with the Washington, the U.S. nuclear industry turning up it lobbying pressure, and the mercantilist Europeans waiting in the wings to gobble up lucrative nuclear deals - made the emergence of a consensus opinion practically impossible. For example, whereas Richard Helms was on the most liberal side of the spectrum, calling for the administration to give the Shah the benefit of the doubt on proliferation, the Department of Defense positioned itself on the conservative extreme advocating the imposition of the most stringent conditions on chemical reprocessing and plutonium stockpiling rights.

The DoD's position was that the issue of chemical reprocessing in sensitive proliferation-prone areas like the Middle East should be "delayed as long as possible" before diversion-resistant mechanisms, like multinational reprocessing facilities, could be

\footnotetext{
${ }^{175}$ Confidential; From New-Alfred L. Atherton, Jr. OES/ Nelson F. Sievering Jr. to Secretary of State. Nuclear Energy Agreement for Cooperation with Iran. December 6, 1974 http://www.gwu.edu/ nsarchiv/nukevault/ebb268/doc04.pdf (Accessed July 16, 2010).
} 
adequately conceptualized and realistically operationalized. Based on this judgment, the DoD believed that Tehran's push for reprocessing rights was premature at least by a decade since Iran wouldn't need such a facility until the mid-1980s. Put simply, the Pentagon's advice was one of "we will cross that bridge when we come to it," advising the administration to avoid jumping the gun on reprocessing and trapping itself into an inflexible commitment. ${ }^{176}$ Heeding such advice would require leaving the issue in as malleable and noncommittal shape as possible, an arrangement certain to be construed by an already skeptical Etemad and company as a dilatory, if not outright obstructive, attitude.

Under these circumstances, Etemad's inflexible insistence on establishing such a capital-intensive reprocessing facility for a budding nuclear program, in the face of concrete evidence against its short-term economic viability, only helped exacerbate the United States' proliferation concerns. In the U.S. judgment, under the prevailing circumstances, anticipated to obtain for another decade or so, "the value of the products from reprocessing (enriched uranium and plutonium) exceeded the costs of reprocessing," thus rendering the spent fuel rods of no commercial value. ${ }^{177}$

Richard Helms, on the other hand, was arguably the most sympathetic figure in the U.S. Government toward concluding a relatively lenient nuclear deal with Iran. As U.S. Ambassador to Iran from March 1973 to January 1977, Helm's friendship with the Shah went way back to the days they were schoolmates in Switzerland's prestigious

\footnotetext{
${ }^{176}$ Secret. Secretary of Defense James R. Schlesinger to Assistant to the President for National Security Affairs, "Nuclear Cooperation Agreement with Iran: NSSM 219," 25 April 1975. http://www.gwu.edu/ nsarchiv/nukevault/ebb268/doc05e.pdf (Accessed July 25, 2010).

${ }^{177}$ Secret. Deputy Secretary of State Charles Robinson to Nuclear Negotiations for Iran. Nuclear Negotiations for Iran. August 13, 1976. http://www.gwu.edu/ nsarchiv/nukevault/ebb268/doc23a.pdf (Accessed June 27, 2011).
} 
boarding school, Institut Le Rosey. Putting aside their interpersonal affinity, Helm's core argument was that a compromise deal with the Shah should be sealed in the interest of time. In the Ambassador's judgment, considering the fact that Washington's nearmonopoly position on nuclear power plants and fuel supply was rapidly wearing out, finalizing an expeditious agreement would not only secure the United States' commercial interests but would, more realistically, be in line with its non-proliferation interests as well. Pursuing a long-drawn-out principle-based-- as opposed to time-sensitive and pragmatic-- negotiating strategy with Iran, in Helm's judgment, would push an otherwise reluctant Iran toward European suppliers who were more likely to bend their counterproliferation standards to reap lucrative power-plant deals. Under such circumstances, Helms argued, perfectionism in negotiating a bilateral deal would be a self-defeating strategy, as it would estrange Iran from the U.S. nuclear community and deprive Washington of a hands-on monitoring advantage to detect proliferation symptoms early on.

In 1975 and arguing against measures that might be construed by the Shah as draconian and discriminatory, Helms maintained, the administration should undertake whatever measures required and in a timely manner to become Iran's "principal supplier for fuel and plant." Helms believed that fostering such a high-density interaction with Iran would make Iran's "most vital interests" so vulnerable to and dependent on the United States that Washington would gain "ultimate sanction against an Iranian desire to develop a nuclear weapons capability." This mechanism, according to Helms, along with 
the NPT and the IAEA guarantees, would give the United States a capability to go for the full-court press should Iran's nuclear program went awry. ${ }^{178}$

The Iranians, on the other hand, stuck to their guns in demanding a nationally built, managed, and operated indigenous chemical reprocessing facility. The issue constituted the most significant reason for the threat designation of the INP in mid 1975. For the Americans, Iran's apparently unexplainable reluctance to act as a site for the United States' multinational reprocessing concept could only stem from an "unspoken unwillingness" to submit Iran's nuclear facilities to "foreign surveillance."179

Cognizant of the strategic implications of concluding a nuclear agreement with Tehran in a timely fashion, in late 1974 Washington showed some readiness to temper its maximalist demands, especially on the issue of US veto rights on indigenous plutonium reprocessing by Iran suggesting it would "look sympathetically" on the issue. The mechanism the United States was entertaining to preclude the diversion of plutonium for proliferation purposes was the establishment of multinational reprocessing plants assisted and monitored by the United States. As this promising development on the executive level was being entertained and as Iran was signaling tentative receptivity to the idea of multinational reprocessing, however, the Ford Administration was forced to re-calcify its negotiating under the pressure of two factors. First, came a hardening of US position due to an increasingly anti-Shah Congress some of whose members had now developed country-specific proliferation concerns about Iran. Under such trust-deficit

\footnotetext{
${ }^{178}$ Secret. Embassy in Tehran to Secretary of State. Draft Agreement on Atomic Energy. April 1975. http://www.gwu.edu/ nsarchiv/nukevault/ebb268/doc05b.pdf (Accessed July 24, 2010).

${ }^{179}$ Secret. From Embassy in Tehran to Secretary of State. Multinational Nuclear Centers: Assessment of Iranian Attitudes toward Plutonium Reprocessing. July 17, 1975. http://www.gwu.edu/ nsarchiv/nukevault/ebb268/doc07.pdf (Accessed May 25, 2011).
} 
circumstances, Iranian concessions, on the concept of multinationalizing reprocessing facilities, wouldn't simply cut it.

The second factor emanated from Washington's proliferation concerns in Pakistan. On this score, as any nuclear deal with Iran would define the broader contours and set a precedent for the United States' post-India nuclear policy, Washington was concerned lest an excessively lenient approach toward Iran have a detractive impact on US efforts to discourage other suppliers from giving Islamabad the reprocessing capability it was feverishly shopping around for. ${ }^{180}$

In any case, a cursory survey of the foregoing four scenarios demonstrates a seemingly irreconcilable disharmony of objectives in the U.S. Government's efforts to negotiate a comprehensive nuclear deal with the Shah. The misalignment of interests flowed, in no small part, from the fact that Washington's macro-security interests, epitomized by the US-USSR superpower rivalry, were inherently clashing with and had a dampening impact on its non-proliferation interests applied to its strategic partners.

The discordance of interests at macro and micro levels in a tightly bipolar international system during the Cold War provided invaluable maneuverability for nuclear aspirants strategically allied with either pole to run proliferation-prone nuclear activities without being publicly singled out or treated as security threats. Iran, for its part, tried to make the most of the gap generated by this incoherence at the geostrategic and doctrinal levels.

As previously mentioned, further widening this gap was the fact that, despite Washington's strenuous efforts, the designation of indigenous nuclear programs as

\footnotetext{
${ }^{180}$ Secret. Report of the NSSM 219 Working Group Nuclear Cooperation Agreement with Iran. April 1975. http://www.gwu.edu/ nsarchiv/nukevault/ebb268/doc05a.pdf (Accessed July 17, 2010).
} 
proliferation threats following the 1974 Indian test was not universally shared. Western European countries, specifically France and Germany, didn't construe the Indian underground explosion as warranting the subordination of their commercial interests to security concerns (as Washington expected) and forged ahead with power plant sales under relatively permissive conditions. It was under such circumstances that Germany's Kraftwork Union AG (KWU) commenced construction of Bushehr Nuclear Power Plants (known as Iran-I and Iran-II) in November 1974 simply based on a letter of intent (LOI) pending the conclusion of a formal contract.

Under these circumstances, as the United States' dominant (its monopoly had already been compromised by now) position in both technological and fuel supply fields was eroding, the divergence in proliferation risk judgments had real consequences if Washington failed to bring Bonn and Paris onto the same page with its threat perceptions. This was exactly the reality of the situation on the ground in the mid-1970s as the United States' efforts to nudge the Shah's nuclear program away from the purely commercial zone into the security zone met with relatively little success in Europe. Put crudely, as far as Germany and France were concerned, the 1973 oil embargo trumped the tentative proliferation implications of India's 1974 explosion and Western Europe's energy imperatives and commercial stakes were just far too high to be abandoned or even put on the backburner.

Additionally adding to the Ford Administration's subpar success to institutionalize its proliferation concerns in Europe was an underlying inconsistency and conflict of interests between crucial commercial incentives and long-range security concerns existing in Washington. For instance, at the same time as Washington was 
perceptibly worried about the scope and depth of the nuclear net the Shah was casting, the U.S. State Department was encouraging the Bechtel Corporation to "approach" the Shah about investing some $\$ 300$ million in a future private uranium enrichment facility in the United States ${ }^{181}$ and was anxious to finalize a six to eight billion dollar reactor and fuel deal with Iran. ${ }^{182}$

Still further complicating the delicate juggling game Washington was playing in the post-1974 era was the unpromising prospect of obtaining the approval of an increasingly trepidations and anti-Shah Capitol Hill whose imprimatur the White House needed before consummating any nuclear deal with Iran. Under these untoward conditions, finding a mutually satisfactory common ground without alienating the Shah in an evolving strategic environment had an air of squaring the circle to it.

In any case, as the Ford Administration was endeavoring to mollify Capitol Hill's heightened non-proliferation concerns without alienating a nettled Shah from the US orbit, a whole slew of external factors were introducing new challenges to an already difficult situation. Important among them was the Shah's dissatisfaction with the treatment he was receiving from Washington when Iran was not invited to the newly established Nuclear Supplier Group's (NSG) first meeting in November 1975 in London. This non-invitation happened despite HIM's expressed strenuous desire for the NSG

\footnotetext{
${ }^{181}$ Confidential. From New-Alfred L. Atherton, Jr. OES/ Nelson F. Sievering Jr. to Secretary of State. Nuclear Energy Agreement for Cooperation with Iran. December 6, 1974. http://www.gwu.edu/ nsarchiv/nukevault/ebb268/doc04.pdf (Accessed July 16, 2010).

${ }^{182}$ Secret. Embassy in Tehran to Secretary of State. Draft Agreement on Atomic Energy. April 1975. http://www.gwu.edu/ nsarchiv/nukevault/ebb268/doc05b.pdf (Accessed July 24, 2010).
} 
members to adopt an interactive approach with the nuclear technology recipient countries instead of blackballing them through the cultish London Club. ${ }^{183}$

Unimpressed by Iran's exclusion from the NSG, in a December 1975 interview with Le Monde, Etemad unleashed a most scathing critique of the NSG's mode of operation: "I find it rather difficult to understand the attitude of the seven [NSG] countries which meet in London regularly with a view to coordinating their attitude toward their nuclear customers," Etemad observed. He then called into question the NSG's "ostensible" objective of preventing nuclear proliferation and charged it with creating an "international atmosphere marked by mistrust and suspicion." The AEOI director went even further wondering, "whether the real motives of the "London Group" did not extend beyond the proclaimed objectives." "If it is true that only non-proliferation is being discussed," Etemad challenged, "why are these talks held behind closed doors? Why are some countries that are more directly concerned with these problems are not asked to join the group?" The AEOI director's rather disturbing prediction was that "as a result of this behavior the nonproliferation treaty [was] being endangered without any real new guarantees being added to the nonproliferation measures already extant." ${ }^{184}$

As evident in these remarks, in Iran's judgment, the NSG epitomized a selfdefeating cloak-and-dagger approach toward proliferation by the Ford Administration

\footnotetext{
${ }^{183}$ Secret. From US Embassy Tehran to Secretary of State. Iranian Views on Non-Proliferation and US/Iran Nuclear Cooperation, June 7, 1976 http://www.gwu.edu/ nsarchiv/nukevault/ebb268/doc19b.pdf (Accessed June 24, 2010).

${ }^{184}$ Foreign Broadcast Information Service (FBIS) Daily Reports, Pairs Le Monde, December 2, 1975, Le Monde Interviews Iranian Nuclear Energy Official, http://docs.newsbank.com/s/HistArchive/fbisdoc/FBISX/11D8BF78E44EC108/0D0CB4F6C367F64A (Accessed May 27, 2011).
} 
whose net result was making the atomic option even more intriguing for nuclear aspirants.

Miffed at Washington's purportedly discriminatory and arbitrary policy of exclusion and inclusion (during a conversation with Ambassador Helms in June 1976) the chairman of the AEOI clearly laid out Tehran's nuclear weapons thinking. Etemad argued that Iran, on geostrategic grounds, thought proliferation "anathema" to its interests and had a much more tenacious vested interest than the United States did in maintaining the Middle East a proliferation-free region. Etemad went on strongly urging the United States to practically help ease a Pakistan “traumatized" by India's May explosion out of its “desperate frame of mind" if Washington didn't wish to see a nuclear Islamabad and its spillover into the Middle East. ${ }^{185}$

In the meantime, as Washington was gaining a fuller understanding of the scope and scale of Iran's nuclear enterprise, the White House's concerns over the Shah's longterm nuclear intentions were growing more acute and pronounced. Now, U.S. Government's secret documents were explicitly questioning the Iranian economy's absorptive capacity and maturity for $23000 \mathrm{MW}$ of nuclear electricity over a matter of two decades. Further undercutting the exclusively electricity rationale for the existence of the nuclear program, in the US judgment, was the fact that Iran's Ministry of Energy, the presumed consumer of the atomic energy, was not institutionally in the decision-making loop of the AEOI. This bureaucratic anomaly further intensified proliferation concerns.

\footnotetext{
${ }^{185}$ Secret. From US Embassy Tehran to Secretary of State. Iranian Views on Non-Proliferation and US/Iran Nuclear Cooperation, June 7, 1976 http://www.gwu.edu/ nsarchiv/nukevault/ebb268/doc19b.pdf (Accessed June 24, 2010).
} 
Around this time, the Americans also started viewing through a jaundiced lens His Majesty's "lively personal interest" in the issue of the atom. The net result was an unprecedentedly candid judgment that "the components of the [Iranian Government's] motivation to acquire this complex and extensive technology [were] not entirely clear." Even less unmistakable was speculation that "it [was] possible that Iran's interest in acquiring nuclear knowhow and plutonium [was], in part, motivated by the desire to preserve the option of developing nuclear weapons should the region's power balance shift toward the nuclear." 186

These misgivings notwithstanding, the Ford Administration was hard at work, with much back and forth going on between different government agencies, to assemble a coherent action plan before a scheduled state visit by the Shah to the United States in May 1975. Knowing full well that the nuclear issue would figure prominently in his negotiations with HIM and succumbing to the Administration's proliferation concerns, President Ford, in NSDM 292, decided to stick with a strict policy of maintaining US veto rights over chemical reprocessing of US supplied fuel on proliferation-risk grounds. The decision was made despite recognition in the Administration that the Shah might interpreter a hardened US posture as an "affront" to his dignity and his country's sovereignty, a scenario that could derail Iran-US relations off their strategic path. ${ }^{187}$

Just as expected, the Shah's high-profile visit to Washington fell well short of extracting concessions on the nuclear front from the Ford Administration. Nor did the

\footnotetext{
${ }^{186}$ Secret. From Embassy in Tehran to Secretary of State, Multinational Nuclear Centers: Assessment of Iranian Attitudes toward Plutonium Reprocessing. July 17, 1975. http://www.gwu.edu/ nsarchiv/nukevault/ebb268/doc07.pdf (Accessed May 25, 2011).
}

\footnotetext{
${ }^{187}$ Secret. National Security Decision Making 292, US-Iran Nuclear Cooperation. April 22, 1975 http://www.gwu.edu/ nsarchiv/nukevault/ebb268/doc05d.pdf (July 25, 2010)
} 
May 1975 NPT review conference and the meetings between Etemad and the American delegation prove fruitful in surmounting the formidable dilemma of Iran's right to reprocessing American supplied fuel rods. If anything, these meetings further widened the trust gap between the Shah and the Americans.

In such an atmosphere, shortly after HIM's U.S. trip, a July 1975 report conducted by the Hudson Institute, founded by Herman Kahn, came down heavily on the possibility of Iran pursuing a deterrent-worthy nuclear option at least within a regional context. The thrust of the report's argument was that the Shah's decision to acquire the nuclear option did not need to be driven exclusively by the developments in Iran's strategic regional environment. Rather, Lewis Dunn, the $\mathrm{ACDA}^{188}$-contracted report's author, argued, an ambitious Shah's desire to acquire military hegemony in the Persian Gulf would constitute enough inducement for Iran to go nuclear in the mid 1980s.

This judgment essentially amounted to a refutation of the Shah's repeatedly articulated position that Tehran would not self-referentially and without being provoked seek a nuclear capability simply to throw its weight around in the Middle East. The report also mentioned an Israeli decision to shed the amimut $^{189}$ and start brandishing its nuclear arsenal or a Pakistani, Libyan, or Egyptian move toward nuclearization as possible scenarios under which Iran would nuclearize.

Following the Hudson Institute report, in an October 1975 cable to Richard Helms, Secretary of State Kissinger drew the Ambassador's attention to the fact that Iran seemed to have calcified its position with Etemad categorically rejecting U.S. demand for

\footnotetext{
${ }^{188}$ Arms Control and Disarmament Agency

${ }^{189}$ For more on amimut or Israel's nuclear opacity, see Avner Cohen, Israel and the Bomb (New York, NY: Columbia University Press, 1999). For a more recent rendition, see Avner Cohen, The Worst-Kept Secret: Israel's Bargain with the Bomb (New York, NY: Columbia University Press, 2011).
} 
veto rights on chemical reprocessing and appearing unreceptive to the concept of multinational reprocessing. As mentioned before, in the Secretary's judgment, Iran's logic-defying reluctance to act as a site for the United States' multinational reprocessing concept could as well flow from an "unspoken unwillingness" to submit Iran's nuclear facilities to "foreign surveillance.",190

In the cable, Dr. Kissinger contextualized the proliferation concerns emanating from such an inflexible stance by Tehran within the broader framework of Pakistan's bid to purchase a pilot reprocessing facility from France and the Shah's September interview with veteran Egyptian journalist Mohamed Hassanein Heikal. ${ }^{191}$ In that interview the Shah had conveyed expressively the reversibility of Iran's nuclear weapons abstinence by saying, "We do not want Iran to procure nuclear weapons just for the sake of having them," before imperiously adding, "But I tell you quite frankly that Iran will have to acquire atomic bombs if every upstart in the region gets them." 192

His Majesty brought this point home more poignantly again in an interview with the New York Times in September 1975: "Honestly, I am not really thinking of nuclear arms. But if 20 or 30 ridiculous little countries are going to develop nuclear weapons, then I may have to revise my policies. Even Libya is talking about trying to manufacture atomic weapons- God knows for what purpose."193

\footnotetext{
${ }^{190}$ Secret. From Embassy in Tehran to Secretary of State, Multinational Nuclear Centers: Assessment of Iranian Attitudes toward Plutonium Reprocessing. July 17, 1975. http://www.gwu.edu/ nsarchiv/nukevault/ebb268/doc07.pdf (Accessed May 25, 2011).

${ }^{191}$ Secret. From Secretary of State to American Embassy Tehran, Nuclear Agreement fro Cooperation. October 25, 1975. http://www.gwu.edu/ nsarchiv/nukevault/ebb268/doc09a.pdf (Accessed June 2, 2010).

${ }^{192}$ Kayhan International, September 16, 1975.

${ }^{193}$ Remarks by Shah on Iran's Policies and Plans, New York Times; Sep 24, 1975.
} 
The subsequent interview by the Shah with Business Week in November 1975 further deepened the fissures in Iran-US ties and made visible the spillover impact of the nuclear standoff in eroding the relationship's strategic depth. In his remarks the Monarch made known his bafflement at the United States' failure to fully appreciate the situation by holding the future progression of such a mutually rewarding strategic partnership hostage to some disagreement over the seemingly trivial issue of chemical reprocessing. Venting out his frustration over the nuclear impasse, the Shah, in thinly disguised language, warned the deadlock could have a systemically detrimental impact and derail Iran-US relations. In the Shah's judgment, the uncompromising treatment Washington was meting out on Tehran's nuclear effort simply symbolized Iran's downgraded status in the United States' strategic hierarchy where, following the euphoric Salt I \& II Treaties and the Helsinki Baskets, détente was the order of the day in US-USSR relations.

Following the sensational coverage the interview received in Tehran's pro-Shah daily Kayhan, the U.S. Ambassador to Tehran sent a sobering cable to Washington. The cable first quoted the Monarch's sentiments in the interview where he contrasted Europe's forthcoming attitude on the nuclear issue with the United States' humiliating demands which the French or Germans, in the Shah's view, would never even dream of making. Helms then elaborated on the Kayhan piece's unmistakable purpose in conveying the broader implications of the nuclear deadlock and lamented the fact that the United States had been so off the mark in assessing the depth and scope of Tehran's disillusionment over the nuclear issue. ${ }^{194}$

\footnotetext{
${ }^{194}$ Confidential. From Embassy in Tehran to Secretary of State, Shah's Interview by Business Week Given Prominent Coverage by English Language Kayhan, November 13, 1975 http://www.gwu.edu/ nsarchiv/nukevault/ebb268/doc09b.pdf (Accessed July 16, 2010).
} 
In another cable sent to State shortly afterward, Helms spoke more concretely about the dilemma, this time offering operational advice to overcome it. Corralling the proliferation concerns associated with chemical reprocessing, the Ambassador drew the State Department's attention to the verity of Etemad's judgment that the concept of multinational reprocessing didn't stand a realistic chance of operational and logistical success considering the impossibly intractable issues like "joint management, distribution of costs, and actual physical arrangements for storage, transport, and processing of material" associated with it in the Middle East. In order to propel the stalled, now almost deadlocked, talks forward, Helms recommended the United States give up on the multinational concept and instead pursue a stringently safeguarded "binational reprocessing plant to be managed and operated by Iran and the United States." ${ }^{195}$ This, in Helms' view, would ensure the US nuclear industry benefitted from the Shah's deep pockets before the lion's share of Iran's nuclear contracts slipped through to the European competitors.

Obviously, conceding so much leeway to Tehran would require the presumption of innocence regarding HIM's ultimate proliferation intentions, a leap of faith the White House was profoundly unprepared to take. Upon close scrutiny, however, one could detect some hardheaded realism combined with a sense of resignation in Ambassador Helms' reading of the Iran-US nuclear cooperation dilemma. The same sense of realism also lodged at the root of the Ambassador's lamentations of the United States' unrealistic obsession with the issue of proliferation. From Helms' vantage point, since Iran's national security imperatives would ultimately reign supreme in its proliferation calculus,

\footnotetext{
${ }^{195}$ Secret. From Embassy in Tehran to Secretary of State, US/Iran Nuclear Agreement, November 26, 1975. http://www.gwu.edu/ nsarchiv/nukevault/ebb268/doc09c.pdf (Accessed July 18, 2010).
} 
whatever precious little contractual concessions the White House managed to squeeze from Tehran would only be of feel-good cosmetic value.

In his characteristically point-blank language, Helms noted, "We have little choice but to accept at face value Iran's stated policy that it intends to honor its NPT commitments. Given the options it now has or may have in the future, it appears to us that the essential point is that Iran could develop a reprocessing plant and proceed to construct a nuclear explosive device if it so desired regardless of any additional safeguards we may succeed in writing into our bilateral agreement. India is an obvious example. Although Iran does not at present have the R\&D cadre to compare with India's, it probably would not take it long to collect or buy the necessary talent to do what India did. With the means in hand, whatever commitments Iran may have made to the US or under the NPT is likely to fall by the wayside if Iran's perception of its national interests so dictate." ${ }^{196}$ As the passage sharply illustrates, Helms was convinced that India's "original sin" could have set off a domino effect, especially in the Middle East, whose dynamics couldn't be manipulated through contractual and legalistic mechanisms. These sentiments were very much in line with those Dr. Etemad expressed in his numerous talks with the American officials.

As the trust deficit between the Peacock Throne and the White House was progressively deepening, Akbar Etemad's late December 1975 visit to India ruffled even more feathers in Washington. ${ }^{197}$ During the trip, one that took place in an atmosphere of

\footnotetext{
${ }^{196}$ Secret. From Embassy in Tehran to Secretary of State. US/Iran Nuclear Agreement. November 26, 1975 http://www.gwu.edu/ nsarchiv/nukevault/ebb268/doc09c.pdf (Accessed July 18, 2010).

${ }^{197}$ Confidential. From Embassy Tehran to Secretary of State Washington. Iranian Nuclear Policy. January 6, 1976 http://www.gwu.edu/ nsarchiv/nukevault/ebb268/index.htm (January 14, 2011).
} 
Iran-India nuclear solidarity, Etemad lavished praise on India's nuclear achievements expressing optimism Iran could "import Indian expertise for developing her atomic research laboratories." Etemad also made mention, in Madras, of Iran's ongoing plans to "set up a chain of atomic research laboratories" that could benefit from India's experience." ${ }^{198}$ These sentiments were more vehemently reiterated by the AEOI director on the sidelines of the conclusion of a sweeping nuclear cooperation agreement in Mumbai between him and Dr. H.N. Sethna, chairman of the Indian Atomic Energy Commission on February 25, 1977. In those remarks, Etemad indicated Iran's interest to "get as much as it can from India, rather than rely too much on Western sources" in the nuclear field. ${ }^{199}$

Particularly alarming to the Americans were insinuations in Etemad's remarks that Iran would be interested in pooling resources with India to explore the possibility of PNEs, an undertaking not explicitly prohibited under the NPT. These sentiments combined with Iran's consistent refusal to condemn the Smiling Buddha ${ }^{200}$ gave further impetus to concerns that Iran was viewing PNEs as a potential loophole in the nonproliferation regime it could capitalize on to position itself in an ambiguous gray zone with possible deterrent benefits. Admiral Quihillal's presence in Tehran only helped intensify these concerns as there was real anxiety in Washington that Brazilian and Argentinean moves toward PNEs would leave Iran with no choice but to follow suit. As

\footnotetext{
${ }^{198}$ Summary of World Broadcasts: The Far East. Weekly supplement, Part 3 (British Broadcasting Corporation. Monitoring Service, 1976).

${ }^{199}$ Foreign Broadcast Information Service (FBIS), Delhi General Overseas Service, February 25, 1977, Nuclear Energy Cooperation Accord Signed With Iran, http://docs.newsbank.com/s/HistArchive/fbisdoc/FBISX/1292EA9190AE6A90/0D0CB4F6C367F64A (Accessed August 23, 2011).

${ }^{200}$ The codename of India's 1974 PNE.
} 
one observer noted in this context, it was "easy to suspect linkages between an interest in explosives in Buenos Aires and in Teheran." 201

In the wake of Etemad's remarks in India (that smacked of endorsement of and interest in PNEs by Iran) the U.S. embassy in Tehran sprang into action pushing AEOI's chief for sharper clarification on whether the comments marked a change of heart in Iran's nuclear policy. Etemad's response was as vague and double-edged as the sentiments expressed in India. While claiming his India remarks had been decontextualized, Etemad went on to reiterate his firm conviction that Iran's nuclear position was "analogous" to that of India. Furthermore, he refused to categorically rule out PNEs as a nuclear route Iran might take - although he said the option wouldn't be taken unilaterally and in breach of Iran's NPT commitments and IAEA safeguards.

Most important of all, however, were the AEOI chief's unequivocal remarks that Iran was determined not to subject its nuclear enterprise to any restrictions imposed by nuclear weapons states (NWS) so long as those were not incorporated into a revised and universally applicable NPT that put equal emphasis on non-proliferation and disarmament. $^{202}$

As time wore on, the virtual nuclear deadlock between Tehran and Washington and its spillover repercussions were growing more visible. For instance, in a January 1976 interview with the Kuwaiti Arabic daily Al-Siyassa, the Shah expressed frustration over the nuclear issue even more crisply: "we have given the Americans a pledge that we will use the nuclear reactors [obtained from the U.S.] for peaceful purposes and that we

\footnotetext{
${ }^{201}$ George H. Quester, "The Shah and the Bomb," Policy Sciences 8, no. 1 (March 1977): 21-32.

202 Confidential. From Embassy Tehran to Secretary of State Washington. Iranian Nuclear Policy. January 6, 1976 http://www.gwu.edu/ nsarchiv/nukevault/ebb268/index.htm (January 14, 2011).
} 
will not produce nuclear weapons. They have asked for more pledges. We believe there is no reason for such pledges." 203

Palpably concerned over the escalating tensions, the White House stepped up its efforts to find the lowest common denominator with Iran to conclude a civilian nuclear agreement as promptly as possible. Reflecting the sense of urgency, in February 1976, National Security Advisor Brent Scowcroft in an unmistakably blunt memorandum-addressed collectively to the Secretary of State, Secretary of Defense, the Director of Arms Control and Disarmament Agency, and The Administrator of the Energy Research and Development Administration-- relayed the President's "anxious" desire to see an accord with Iran in a timely fashion. Despite its urgent language, however, the memo revealed that Washington was yet to capture a sharp picture of the conditions the Iranian would find absolutely non-negotiable.

This sense of loss was as much a function of the protracted nature of the talks and changing circumstances--that made the evolution of the two sides' positions inevitableas the shift in Iran's appraisal of the indispensability of the U.S. to get its nuclear program off the ground (especially with regards to the issue of fuel supply). Under such dynamic circumstances, the Ford Administration's efforts to find common ground between "US proliferation interests, US-Iran mutual interests, and US domestic nuclear politics" was as unrealistic as Washington's exhortations with Iran to forsake national reprocessing and become a role model for the rest of the world. ${ }^{204}$

\footnotetext{
${ }^{203}$ Foreign Broadcast Information Service (FBIS) Daily Reports, Kuwait As-Siyasah, January 20, 1976-0120, Shah Grants Interview to Kuwaiti As-Siyasah. http://docs.newsbank.com/s/HistArchive/fbisdoc/FBISX/11D8C5C359B7F818/0D0CB4F6C367F64A (Accessed August 26, 2011).

${ }^{204}$ Secret Memorandum. From Brent Scowcroft for The Secretary of State, The Secretary of Defense, The Director of the Arms Control and Disarmament Agency, The Administrator of the Energy Research and
} 
Under these circumstances, as the February 2, 1976 meeting between the Shah and the U.S. delegation (director of the Energy Research and Development Administration, Robert Seamans and Under Secretary for Security Assistance, Caryle Maw) produced no concrete results, the Administration showed signs of receptivity to the Iranian redlines. The United States, in the talks, agreed to further concessions by scrapping the "veto rights" stipulation and by granting Iran the right to operate a "rigorously safeguarded" national reprocessing facility on Iranian soil. But Washington was still concerned that even these concessions might fall short of meeting Iran's demands regarding a genuinely indigenous full fuel cycle if "rigorously safeguarded" meant "assigning [American] staff to an Iranian national facility to supplement IAEA safeguards." 205

As the Ford Administration was stepping up its efforts to work out a viable modus vivendi with the AEOI, Ambassador Helms' hardnosed appraisals of the situation proved somewhat instrumental in softening the contours of the U.S. nuclear posture toward Iran. Arguably the most consequential result of Helms' exhortations for the Administration to be pragmatic was that the notion of multinational reprocessing was dropped, at least informally, from the United States' list of counter-proliferation solutions. In a May 12, 1976 meeting with high-ranking State Department officials, secretary Kissinger revealed his change of heart on the issue as well: "I am frankly getting off the multinational concept. I have endorsed it publicly, but in any region you look at it is a fraud. Pakistan

Development Administration. Next Steps in Our Negotiations of a Nuclear Agreement with Iran. February 4, 1976; http://www.gwu.edu/ nsarchiv/nukevault/ebb268/doc11.pdf (Accessed July 28, 2010).

${ }^{205}$ Secret memorandum. From Myron Kratzer and Alfred Atherton to the Secretary. "Next Step in Our Nuclear Negotiations with Iran," March 25, 1976. http://www.gwu.edu/ nsarchiv/nukevault/ebb268/doc13.pdf (Accessed July 27, 2010) 
does not want to be in a plant located in Iran and a plant in Pakistan would just be a cover... I am not sure we should fall on our own swords to push others into multinational projects."

The Secretary of State didn't just stop there. In some eerily candid remarks, reminiscent of Ambassador Helms' hardheadedness, Kissinger undercut even further the sustainability of the whole concept of multinationalizing fuel cycles, wondering what would happen if the host country "kicked out" the other participants once the facility was up and running. On top of that, Kissinger appeared to have serious second thoughts whether multinationalization on the cheap would contribute to the proliferation of reprocessing technology to countries that wouldn't otherwise have access or, for that matter, even interest in it. ${ }^{206}$

Just as the shedding of the multinational reprocessing concept was promising to pave the way for the conclusion of an agreement with the AEOI, the Iranian side managed to rekindle Washington's worst fears when the Shah's purported desire to purchase fast breeder reactors (FBR) became widely known. ${ }^{207}$ This desire was more concretely articulated in July 1976 when Tehran officially informed the United States of "the construction of experimental and commercial fast breeder reactors [as] part of Iran's atomic energy program." 208 FBRs are essentially plutonium-fueled reactors, a technology

\footnotetext{
${ }^{206}$ Secret. Memorandum of Conversation. Proposed Cable to Tehran on Pakistani Nuclear Reprocessing. May 12, 1976 http://www.gwu.edu/ nsarchiv/nukevault/ebb268/doc17.pdf (Accessed June 25, 2010).

${ }^{207}$ Secret. Report of the NSSM 219 Working Group Nuclear Cooperation Agreement with Iran. April 1975. http://www.gwu.edu/ nsarchiv/nukevault/ebb268/doc05a.pdf (Accessed July 17, 2010). Also see, Secret. Memorandum for Mr. Brent Scowcroft. Next Steps in Our Nuclear Negotiations with Iran. April 16, 1976 http://www.gwu.edu/ nsarchiv/nukevault/ebb268/doc15.pdf (Accessed June 14, 2010).

${ }^{208}$ Confidential. From US Embassy Tehran to Secretary of State. Iranian Counterproposals for Atomic Energy Agreement. July 23, 1976. http://www.gwu.edu/ nsarchiv/nukevault/ebb268/doc21.pdf (Accessed July 27, 2010).
} 
that makes weapons-grade fissile material readily available for weaponization. This was exactly the path India took to acquire the plutonium used in its 1974 nuclear explosion.

Right about the same time, alarming news trickled out that the Shah's nuclear enterprise was being rushed forward at an alarmingly accelerated pace. For instance, there was word circulating in the nuclear industry sector that the Shah was pushing Germany's KWU to finish the Bushehr power plant's first unit by October 1981so it could be ready for Prince Reza's $21^{\text {st }}$ birthday when he would be crowned as Crown Prince. ${ }^{209}$ The venturesome fashion in which Iran was pursuing the full spectrum of almost all available and futuristic nuclear possibilities exuded a feeling of urgency that the Washington couldn't help but associate with some imminent threat perception by Iran. Although the U.S. didn't explicitly raise the hurried pace of Tehran's nuclear journey as a matter of substantive concern in the negotiations with the Shah, its atmospheric impact in breeding the United States' proliferation anxieties was unmistakably perceptible. For example, the very fact that the area adjacent to Halileh was abruptly re-allocated from its original purpose as a petrochemical plant site to host the Bushehr Power Plants is quoted in a State Department cable as evidence that the nuclear issue enjoyed unusual prioritization. ${ }^{210}$

In this connection, it is worth mentioning that the issue of site selection for Iran's nuclear plants was also an object of curiosity. This had to do with the very fact that Iranian territory, due to high seismic activity where water was abundant, was hardly a

\footnotetext{
${ }^{209}$ Confidential. Airgram from the US Embassy Tehran to the Department of State. The Atomic Energy Organization of Iran. April 15, 1976. http://www.gwu.edu/ nsarchiv/nukevault/ebb268/doc14a.pdf (Accessed April 14, 2011).

${ }^{210}$ From US Embassy Tehran to Department of State. "The Atomic Energy Organization of Iran, AEOI. May 11, 1977 http://www.gwu.edu/ nsarchiv/nukevault/ebb268/doc14b.pdf (Accessed April 23, 2011).
} 
hospitable ground for building power plants. As a matter of fact, only four regions in the entire country could even be considered as candidates for nuclear power construction. Of these feasible areas, the Caspian Sea coast was dismissed due to a host of environmental and geological reasons, water level fluctuations, and strategic considerations associated with its proximity to the Soviet Union. High seismicity rendered the Persian Gulf coast only a marginally better candidate. The Karun River banks was another possibility that the AEOI decided upon by contracting two 900 MWe power plants to the French company Framatome. The last option was to build air-cooled nuclear plants on the banks of the Zayandeh River near Esfahan for which the AEOI was in preliminary talks with KWU. On the Bushehr plants, critics expressed concern that KWU and the AEOI had compromised safety measures, as the plants were not suitable for an earthquake prone region. ${ }^{211}$

As the rift between Iran and the United States was widening, another layer of uncertainty began to capture the Americans' attention: Visible signs of growing antiAmericanism had crept into the corporate culture of Iran's now sizable and fiercely nationalistic nuclear bureaucracy. Under the prevailing conditions, the AEOI's antiAmerican bias could only intensify over time as Etemad and his senior staff were coming to internalize the fundamental contrast between Washington's hardball nuclear politics with the Western Europeans' easygoing attitude. This reality and its bearing on the future trajectory of Iran's nuclear program was of great concern to the United States.

In April 1976 and May 1977, for example, the U.S. Embassy in Tehran put together two comprehensive character sketch profiles of key personnel involved in the

${ }^{211}$ Technology Transfer to the Middle East (Washington D.C.: U.S. Congress. Office of Technology Assessment. OTA-1 SC-173, September 1984). 
AEOI's main decision-making offices and domestically affiliated subcontracting firms. These rather detailed cables made a point of going into the key personnel's backgrounds and political orientations. In the 1977 cable, for example, Dr. Ghassem Arabian, the AEOI Deputy in Charge of Raw Materials and Fuel and one of Etemad's "first and foremost trusted assistants" was singled out as having an "anti-American bias." ${ }^{212}$ In this regard, in an August 1976 cable explaining the roots of the AEOI's obdurate attitude toward the nuclear bilateral, Ambassador Helms placed the blame squarely on Etemad's "senior staff." $" 213$

\section{Lame-duck Ford Replaced by Anti-Nuclear Carter}

As the Ford Administration was going through its lame-duck year, the real damage done to the U.S. nuclear industry started to dawn on the White House. The sobering news came in April 1976 when the U.S. embassy in Tehran informed the State Department that due to the United States' lethargic pace in concluding a comprehensive nuclear deal with Iran and the Shah's dwindling oil revenues, the ambitious 23000 megawatts nuclear electricity generating program would be "stretched out over a longer period" than initially conceived.

This meant that new orders on top of the four already concluded with Germany and France would be "deferred." The cable, in an apparent effort to at least partially shift the culpability from the U.S. government to the nuclear industry, blamed American companies' reluctance to enter into the so-called "super turn-key contracts" (that the

\footnotetext{
${ }^{212}$ Confidential. From US Embassy Tehran to Department of State. "The Atomic Energy Organization of Iran, AEOI. May 11, 1977 http://www.gwu.edu/ nsarchiv/nukevault/ebb268/doc14b.pdf (Accessed April 23, 2011).

${ }^{213}$ Confidential. From Embassy Tehran to Secretary of State. Nuclear Energy Discussion (or How we Gave the Farm Away) August 3, 1976 http://www.gwu.edu/ nsarchiv/nukevault/ebb268/doc22.pdf (June 26, 2010).
} 
European vendors were willing to do) for failing to secure a solid foothold for the U.S. companies in Iran's lucrative nuclear market. ${ }^{214}$

It is noteworthy that the notion of "super turn-key projects" was a term coined specifically to describe the terms and conditions the AEOI was demanding of vendors bidding to build nuclear reactors in Iran. Such an arrangement essentially required the foreign contractor to not only supply the project to the AEOI in ready-to-operate shape but also develop and initially manage all the "ancillary facilities" like "water supply, homes for the personnel" and the like "in places where there literally was no electricity at all." According to one source, "the 'outside the fence' costs for these projects would exceed the 'inside the fence' costs for a number of years" since "the provision of water and housing and mosques could cost more than the nuclear equipment itself., ${ }^{215}$

In any case, with Iran scaling back its ambitious nuclear program and the election season coming up in 1976, the finalization of a bilateral nuclear agreement with Iran lost its urgency toward the end of the Ford Administration. Despite the Ford Administration's strenuous efforts to conclude a bilateral agreement to supersede the Nuclear Agreement between the US and Iran signed on March 5, 1957 and amended and modified by the follow-up agreements of June 8, 1964, and March 18 1969, the three shots Washington

\footnotetext{
${ }^{214}$ According to the document, "the American companies proved slow to respond to the AEOI's insistence upon receiving proposals incorporating not only construction of plants per se but also training of the personnel to man them, provision of the enriched uranium to fuel them, and construction and operation of all the local infrastructure necessary to build and run them. The Iranians felt they had to press for so-called super-turnkey contracts, because they had no experience in nuclear power and because the most likely sites for the plants were on the south coast, an area which is practically a wilderness. The American companies were reluctant to commit themselves to such ventures in a foreign environment, especially since they had lost heavily on turnkey projects in the U.S. when American utilities, too, were entering the nuclear age." See Confidential. Airgram from the US Embassy Tehran to the Department of State. The Atomic Energy Organization of Iran. April 15, 1976. http://www.gwu.edu/ nsarchiv/nukevault/ebb268/doc14a.pdf (Accessed April 14, 2011).

${ }^{215}$ George H. Quester, “The Shah and the Bomb,” Policy Sciences 8, no. 1 (March 1977): 21-32.
} 
took at the issue in February and May 1975 and May 1976 alongside a massive diplomatic effort fell well short of sealing a deal.

The last draft, submitted to the government of Iran on May 31, 1976, in Washington's judgment, contained the most ground the United States could concede without jeopardizing its non-proliferation interests and the uniformity of policy and practice it was seeking to adhere to in its future peaceful nuclear cooperation deals. An increasing self-confident and assertive AEOI's feedback on the US proposed draft, however, was nothing if not defiant. For instance, diametrically opposed to the United States' position of demanding "veto rights" over the reprocessing of US supplied fuel, the AEOI proposed "the Imperial Government of Iran" be granted "the right to effective control of the management and operation of the reprocessing facilities."216

At the core of this fundamental disagreement were two different attitudes towards the issue of reprocessing in Tehran and Washington: Washington viewed the issue as a privilege (with security implications) to be granted under the most parsimonious of circumstances to some of the United States' strategic allies, but the AEOI and especially its chairman Akbar Etemad viewed it as an inalienable right (with sovereignty implications) Iran could not be arbitrarily or discretionarily deprived of. In Etemad's perspective, Iran was entitled to the full spectrum of "nuclear technology, including reprocessing."217

\footnotetext{
${ }^{216}$ Confidential. From US Embassy Tehran to Secretary of State. Iranian Counterproposals for Atomic Energy Agreement. July 23, 1976. http://www.gwu.edu/ nsarchiv/nukevault/ebb268/doc21.pdf (Accessed July 27, 2010).

${ }^{217}$ Confidential. From Embassy Tehran to Secretary of State. Nuclear Energy Discussion (or How we Gave the Farm Away) August 3, 1976. http://www.gwu.edu/ nsarchiv/nukevault/ebb268/doc22.pdf (June 26, 2010).
} 
Again, it was Ambassador Helms who, in his characteristically sympathetic tone to Iran's nuclear sentiments, laid out his appraisal of Iran's reprocessing rights counterproposal in disarmingly simple terms:

'Iran considers reprocessing as an important 'downstream' activity, and for obvious security of supply and economic reasons seriously intends to have it performed in facilities established in Iran. The United States, desiring to sell a large number of power plants, in all fairness, should be prepared to supply Iran with the means to establish all facilities which in the opinion of the Iranian government constitute integral parts of its nuclear power program. "218

If presidential-hopeful Jimmy Carter's campaign rhetoric was any indication, one could see a further tightening of U.S. nuclear technology transfer and conventional arms sales to Iran if he became president. Indicative of this was a presidential debate on October 6, 1976 during which Carter launched a scathing critique on the lavish shipment of military hardware by the Ford Administration to the Shah: "Iran is going to get 80 F14s before we even meet our own Air Force orders for F-14s, and the shipment of Spruance-Class Destroyers to Iran are much more highly sophisticated than the SpruanceClass Destroyers that are presently being delivered to our own Navy. This is ridiculous and it ought to be changed." 219

Before long, with Jimmy Carter winning the White House came sweeping changes to U.S. nuclear policy and further hindrances to the finalization of a bilateral

\footnotetext{
${ }^{218}$ Confidential. From US Embassy Tehran to Secretary of State. Iranian Counterproposals for Atomic Energy Agreement. July 23, 1976. http://www.gwu.edu/ nsarchiv/nukevault/ebb268/doc21.pdf (Accessed July 27, 2010).

${ }^{219}$ Presidential Campaign Debate Between Gerald R. Ford and Jimmy Carter October 6, 1976. http://www.fordlibrarymuseum.gov/library/speeches/760854.asp (Accessed July 14, 2011).
} 
agreement between Tehran and Washington. The person in charge of devising the United States new strategy was Joseph Nye, Deputy to the Undersecretary of State for Security Assistance, Science, and Technology who also led the National Security Council Group on Nonproliferation of Nuclear Weapons. Iran's response to the change in the Carter administration's introduction of more stringent guidelines on nuclear materials, technology, and equipment was expectedly incompliant. For example, in a February 1977 press conference, Iran's top nuclear official, while soft-pedaling Tehran's obdurate reprocessing position, defiantly reiterated a well-known Iranian theme: that "no country or group of countries" should think they have the "right to dictate nuclear policy" on Tehran. ${ }^{220}$

With Carter in power, Iran soon found itself on the receiving end of his Administration's more stringent nuclear policy in mid 1977 when its request for 20.2 kilograms of highly enriched uranium (HEU) for the Tehran Research Reactor (TRR) received skeptical reception in Washington on the grounds it exceeded the 6-kilogram ceiling stipulated in the last amendment to the bilateral Nuclear Cooperation Agreement (NCA) in 1969.

The AEOI's request for an increased amount of HEU was part of an effort "to replace existing plate-type fuel elements to extend core lifetime and boost power level from five to ten megawatts" at the TRR scheduled for mid $1978 .{ }^{221}$ President Carter's failure to sanction the transfer of HEU occurred despite the American Embassy's blunt

\footnotetext{
${ }^{220}$ Quoted in Unclassified. From US Embassy Tehran to Secretary of State. Nuclear Power: Comments of Head of Atomic Energy Organization of Iran (AEOI) February 7, 1977.

http://www.gwu.edu/ nsarchiv/nukevault/ebb268/doc25a.pdf (Accessed August 6, 2010).

${ }^{221}$ Confidential. From Secretary of State to US Embassy Tehran. Highly Enriched Uranium (HEU) Export to Iran. May 9, 1977 http://www.gwu.edu/ nsarchiv/nukevault/ebb268/doc29a.pdf( Accessed May15, 2011).
} 
warning that it would "feed" Tehran's "worst fears concerning the reliability of the US as a future supplier of nuclear materials" likely to be construed in Iran as yet another indication that Tehran was not receiving a nuclear treatment commensurate with its strategic weight as a close ally.

This issue acquired even more prominence when, as the U.S. Embassy in Tehran noted, set against the backdrop of May 4, 1977 "presidential announcement of approval of significant quantities of HEU to 8 projects in Canada, the Netherlands, Japan, Belgium, and the FRG." This discriminatory authorization reinforced already held suspicions in Tehran that "the U.S. has and will continue to differentiate between various customers in favor of the industrial west." 222

This differentiated treatment became even more conspicuous with President Carter's commencement speech at Notre Dame University in June 1977. The tenor of the speech couldn't have been more foreboding for the person of the Shah. "We are now free of that inordinate fear of communism which once led us to embrace any dictator who joined us in that fear," the President intoned, before adding, "I'm glad that that's being changed." 223

Visibly miffed, Tehran took an expeditious and unprecedentedly visible leadership role on the international stage in response to the Carter administration's new nuclear policy announced on 7 April 1977. The high-profile venue for this trailblazing role was the AEOI-sponsored Iran Conference on Transfer of Nuclear Technology held at Persepolis a mere three days after the introduction of the U.S. new policy.

\footnotetext{
${ }^{222}$ Confidential. US Embassy Tehran to Secretary of State. Highly Enriched Uranium (HEU) export to Iran. May 12, 1977 http://www.gwu.edu/ nsarchiv/nukevault/ebb268/doc29a.pdf (Accessed may 12, 2011).

${ }^{223}$ Jimmy Carter, "Commencement Speech Given at Notre Dame University ," June 1977.
} 
Enthusiastically attended by the nuclear have-nots and the biggest nuclear energy conference in the world, the event brought together some 500 nuclear scientists and officials "from the West, the Eastern bloc and the developing countries."224

In his message to the Conference, President Carter supplemented his backhandedly complimentary comments by raising the pathologies associated with nuclear technology. "I am profoundly interested in nuclear energy and am acutely aware of its possibilities and potential danger" the President noted, adding, "In this connection, all countries ought to be aware of their responsibilities in enabling the human community to benefit from the knowledge of nuclear technology within the framework of preventing its destructive consequences." ${ }^{.25}$

The Shah's response to Carter's message was equally double-edged: "Your Excellency: I wish to emphasize the fact that I fully realize your special interest in the nuclear energy issue. I am fully aware of the dangers and problems which might arise for the human community from an irresponsible policy. In this regard, I wish to reiterate that Iran has devoted its efforts solely toward the peaceful use of nuclear energy and that in the future we will continue to cooperate with all countries of the world toward realizing this objective in the interest of the entire human community."226

\footnotetext{
${ }^{224}$ Foreign Broadcast Information Service (FBIS) Daily Reports, Teheran Domestic Service, Mach 28, 1977. Plans Announced for Atomic Energy Conference. http://docs.newsbank.com/s/HistArchive/fbisdoc/FBISX/11D851005700A818/0D0CB4F6C367F64A (Accessed August 24, 2011).

${ }^{225}$ Foreign Broadcast Information Service (FBIS) Daily Reports, Teheran Domestic Service April 10, 1977. Shah Replies to Carter's Message on Nuclear Spread. http://docs.newsbank.com/s/HistArchive/fbisdoc/FBISX/11D7A63DC1F1A288/0D0CB4F6C367F64A (Accessed August 26, 2011).

${ }^{226}$ Foreign Broadcast Information Service (FBIS) Daily Reports, Teheran Domestic Service April 10, 1977. Shah Replies to Carter's Message on Nuclear Spread. http://docs.newsbank.com/s/HistArchive/fbisdoc/FBISX/11D7A63DC1F1A288/0D0CB4F6C367F64A (Accessed August 26, 2011).
} 
At the conference, the Indian delegation caught the Americans off guard by labeling "anything that smacked of restriction" on nuclear technology by the nuclear haves "as a direct threat to [India's] prospects for economic growth." This position jibed well with the Iranian position proving yet again how intertwined Iran and India's nuclear positions had grown over the years. The tenor of the panels and discussions at the conference left the American delegation with a most sobering impression: that "nuclear energy policy in the future will be used in fora as a focus for rallying Third World unity vis-à-vis the United States."227

On the sidelines of the conference came surprising pieces of news by the AEOI Director in charge of Prospecting, Extraction, and Fuel according to whom Iran would no longer allow "foreign investors" to participate in the projects on the enrichment of uranium on its territory. The AEOI also announced it had concluded contracts with several countries to purchase some 30,000 tons of enriched uranium to be delivered in installments by 1994. The IAEOI also disclosed plans to "invest 300 million in the exploration for uranium at home over the next 10 years. $" 228$

An unintended consequence of the event was that even if the United States was, in principle, willing to give the benefit of the doubt to Iran as a reluctant NPT member, the Persepolis conference in April 1977 threw Iran's stance on the issue into sharp relief as it

\footnotetext{
${ }^{227}$ Confidential. American Consulate Shiraz to Department of State. The Persepolis Conference on Transfer of Nuclear Technology: A Layman's View. April 18, 1977, http://www.gwu.edu/ nsarchiv/nukevault/ebb268/doc27.pdf (Accessed February 23, 2011).

${ }^{228}$ Foreign Broadcast Information Service (FBIS) Daily Reports, Teheran Domestic Service April 12, 1977, No Foreign Investment to Be Permitted in Uranium Project http://docs.newsbank.com/s/HistArchive/fbisdoc/FBISX/11D7A63E1DDADE38/0D0CB4F6C367F64A (Accessed August 29, 2011).
} 
betrayed an Iranian effort to position itself at the forefront of cultivating an alternative nuclear energy paradigm in the developing world.

Following the Conference and pressing ahead with his defiant posture toward Carter's nuclear policy, in an April 1977 official visit to Tokyo, the AEOI director unleashed another round of blistering criticisms of Washington's nuclear behavior. Reiterating Tehran's indignation at the London Club, Etemad warned, "Many countries who have signed the NPT have lost their previous confidence and trust in this agreement. ${ }^{, 229}$

Shortly following the Japan trip, during a meeting between Etemad and a US State Department delegation in May 1977, the Iranian position on the new US nuclear energy policy became even more cut and dry when the AEOI chief aired a litany of complaints against Washington. On the NPT, Etemad lamented a lack of "distinction" by the United States "in its handling of NPT and Non-NPT countries," claiming Tehran had "not benefitted" from joining the treaty. Also prominently figuring in Etemad's list of grievances was the United States' discriminatory treatment of different articles of the NPT. Chief among Tehran's remonstrations on this score was Washington's reluctance to "give full weight to its responsibilities under article 4 of the NPT" that called for "the fullest possible exchange of equipment, materials and scientific and technological information for the peaceful uses of nuclear energy" ${ }^{230}$ between nuclear haves and havenots. Etemad took the U.S. to task for its lack of systematic cooperation on full

\footnotetext{
${ }^{229}$ Foreign Broadcast Information Service (FBIS) Daily Reports, Teheran Domestic Service $\quad$ April 25, 1977, Etemad Discusses Nuclear Cooperation Issues, U.S. Policy http://docs.newsbank.com/s/HistArchive/fbisdoc/FBISX/11D859E2CFA8E558/0D0CB4F6C367F64A (Accessed August 28, 2011).

${ }^{230}$ The Treaty on the Non-proliferation of Nuclear Weapons (NPT) http://www.un.org/en/conf/npt/2005/npttreaty.html (Accessed June 15, 2011).
} 
technology transfer as a matter of overriding concern to Iran. The London Club, another of the perennial items on Etemad's woe list, was raised with the United States delegation as well. The AEOI chief made no secret of the Iranian government's "bad feeling" about the news trickling out of the NSG's sub-rosa meetings that essentially amounted to the excommunication of the nuclear have-nots from the inner circle of international nuclear decision-making and threatening their relegation into an outcast nonentity. ${ }^{231}$

It is worth mentioning here that the allegedly cultish nature of decision-making in the London Club continued to be a recurring bone of contention between Iran and the west in the Islamic Republic era. The Iranians alleged that the London Club had morphed into a mechanism to perpetuate the atomic powers' "apartheid" monopoly on nuclear technology, a reality that belied the latter's adherence to the spirit, if not the letter, of the NPT's article IV.

At pains not to pass up any opportunity to take jibes at Washington's nuclear policy, in September 1977 the Shah dispatched a critical message to the 21st General Annual Conference of the IAEA in Vienna. HIM, in unusually candid language, called "any attempt to replace" international non-proliferation regimes "by bilateral and multilateral agreements a real danger for [their] solidarity and effectiveness." ${ }^{232}$

As the tumultuous clouds were looming on Iran's domestic political scene, the Shah-sympathetic Richard Helms' departure from Tehran in December 1976 and the sixmonth delay in his replacement (on June 1, 1977) added yet another complicating wrinkle

\footnotetext{
${ }^{231}$ Confidential. US Embassy Tehran to Secretary of State US-Iran Nuclear Cooperation Agreement and US-Iran Energy Discussions. May 16, 1977. http://www.gwu.edu/ nsarchiv/nukevault/ebb268/doc28.pdf (Accessed July 27, 2010).

${ }^{232}$ Foreign Broadcast Information Service (FBIS) Daily Reports, Teheran, September 28, 1977, Shah Sends Message to IAEA Conference in Vienna, http://docs.newsbank.com/s/HistArchive/fbisdoc/FBISX/11D7C66EA716AB08/0D0CB4F6C367F64A (Accessed July 28, 2011).
} 
to an already nebulous ambiance between Tehran and Washington. Helms' replacement, William Sullivan, couldn't have been a worse candidate to bridge the gap between Tehran and Washington's nuclear negotiating positions. A career diplomat deeply disillusioned with the Shah, the new Ambassador tended to view with resignation the gathering storm unleashed by the clerics on a seemingly doomed monarchical regime. To make matters worse, he also visibly lacked the kind of authority and judgment on the nuclear issue that his predecessor had brought to the U.S. Embassy in Tehran. Under Sullivan's ambassadorship there are essentially no visible signs in the cables of Helmsstyle efforts to smooth over nuclear matters with Washington.

As Tehran was progressively moving apart from Washington in charting its nuclear program, Iran's ties to France and Germany were growing tighter. On November 10, 1977 Tehran signed a declaration of intent with the German firm Kraftwork Union (KWU) to build four additional power plants (on top of the two previously under construction by KWU) near the town of Saveh in central Iran. These reactors would collectively generate 4,800 MWe and were slated to come online between 1984 and 1987. Dr. Etemad described the agreement, the largest and most comprehensive ever entered into by the AEOI, as "the most important event in the economic relations between the Federal Republic [of Germany] and Iran." The timing of the announcement of the agreement, described by diplomatic circles as a "shot across the bow" of the United States by Iran just five days ahead of HIM's scheduled state visit to Washington, could hardly have been more rankling for the White House. The U.S. nuclear industry was especially irked since the Shah was scheduled to discuss with President Carter the issue of eight 
nuclear reactors Tehran had been seeking to purchase from Westinghouse for over a year. $^{233}$

In such an atmosphere, in May 1978, the United States submitted yet another draft of an NCA to Iran following a round of negotiations held in Vienna in February 1977. The draft reflected Iran's half-hearted acquiescence in the face of U.S. pressure to have a decisive say on the chemical reprocessing of spent fuel rods. It stipulated that Iran would not have the right to reprocess or engage in any reprocessing activity without Washington's prior consent. ${ }^{234}$

But even here there was only a partial meeting of minds as the devil in the details soon reared its head. The United States was in favor of a two-tiered arrangement for the "disposition of irradiated special nuclear material" that gave priority to storage of spent fuel either in Iran or the United States and only entertained reprocessing as "an option of last resort" if the storage option proved "impracticable" due to unfavorable "technical, economic, or political" circumstances. The Iranians, on the other hand, were pursuing an arrangement that would grant them the reprocessing right as "an equal option" on par with the storage option. ${ }^{235}$

This last remaining complicating wrinkle was never completely ironed out as the United States got wind of a sweeping change-of-heart in Iran's nuclear energy policy on

${ }^{233}$ Foreign Broadcast Information Service (FBIS) Daily Reports, Hamburg DPA, November 10, 1977. Nuclear Power Plant Agreement with FRG Firm Signed. http://docs.newsbank.com/s/HistArchive/fbisdoc/FBISX/11D81432C67C4F10/0D0CB4F6C367F64A (Accessed August 26, 2011).

${ }^{234}$ Confidential. Secretary of State to US Embassy Tehran. U.S.-Iran Nuclear Cooperation Agreement, May 17, 1978 http://www.gwu.edu/ nsarchiv/nukevault/ebb268/doc31a.pdf (Accessed May 13, 2011).

${ }^{235}$ Secret. From Secretary of State to US Embassy Canberra and Ottawa, Provisions of US-Iranian Nuclear Cooperation Agreement. September 6, 1978 http://www.gwu.edu/ nsarchiv/nukevault/ebb268/doc31b.pdf (Accessed May 14, 2011). 
August 15, 1978 that cast serious doubt on the feasibility for Iran to purchase eight nuclear reactors from the U.S. nuclear industry as initially conceived. The news came in the form of a front-page article in The Kayhan International entitled "It's Time to Call a Moratorium on all New Negotiations in Nuclear Sector" that took to task the United States' brassbound approach on reprocessing and its dilatory attitude toward the conclusion of the NCA.

Throwing into doubt the expediency of finalizing the NCA in a rush mode and at a time when a comprehensive overhaul of Iran's energy policy was on the cards, the editorial counseled, "Iran should not rush into an agreement [with the US] whose implications over the next decade or two are at best unclear, and at worst undesirable."236

The Kayhan editorial's prediction was on the money as shortly afterward, Iran scrapped all new nuclear power plant projects except the four units already under construction in Halileh by KWU and Darkhovin by Framatome. This came about, partly, thanks to plummeting oil prices that rendered the Iranian economy incapable of buoying the AEOI's nuclear extravaganza. Aside from the dwindling oil revenues, the INP was further plagued and started showing signs of faltering by two new elements: a host of domestic opposition pressures leveled by various interest groups like the environmentalists ${ }^{237}$ further complicated by intergovernmental turf wars especially with the Ministry of Oil. Amid the mounting domestic opposition to the nuclear program and a charged political atmosphere, the AEOI was stripped of a big chunk of its decision-

\footnotetext{
${ }^{236}$ Confidential. US Embassy Tehran to Secretary of State. Reassessment of Iran's Nuclear Energy Plans. August 17, 1978 http://www.gwu.edu/ nsarchiv/nukevault/ebb268/doc32a.pdf (Accessed May 15, 2011).

${ }^{237}$ Confidential. US Embassy Tehran to Secretary of State. Nuclear Activities in Iran. May 21, 1978. http://www.gwu.edu/ nsarchiv/nukevault/ebb268/doc32b.pdf (Accessed May 16, 2011).
} 
making power over "planning, constructing, and operating power plants" as these powers were transferred to the Ministry of Energy. An immediate result of the rethinking of Iran's unrealistically ambitious nuclear program was the scrapping of four plants under negotiation with KWU, two with Framatome, and some eight plants with Westinghouse.

Shortly following the bureaucratic and policy overhaul, in October 1978, the Shah's "bureaucratic superstar" and AEOI director, Akbar Etemad, now commonly perceived as the father of Iran's nuclear program, along with a handful of his highranking deputies resigned their posts amidst "allegations of mismanagement and embezzlement." ${ }^{238}$ Etemad's replacement was his deputy in charge of Power Plant Projects, Ahmad Sotoodehnia, a U.S. trained nuclear engineer who had worked for the National Iranian Oil Company (NIOC) before joining the AEOI. ${ }^{239}$

On the environment front, the AEOI received a lot of public criticism following some headline grabbing news that the AEOI was making arrangements with the Austrian government, with the Shah's consent, allowing the latter to use Iran's Kavir Dessert for nuclear waste disposal purposes in exchange for receiving technological cooperation from Vienna. Concerns were also raised by a senior nuclear safety member at the IAEA alleging that the Bushehr reactors, in the interest of time, had not gone through some significant design modifications that would be imperative to make it operationally safe for a "relatively high seismic area." Not surprisingly, the AEOI officials categorically denied these allegations claiming no safety standards had been compromised. ${ }^{240}$

\footnotetext{
${ }^{238}$ New Scientist, "Political Upheavals Hit Iran's Nuclear Program," November 30, 1978: 667.

${ }^{239}$ Confidential. From US Embassy Tehran to Department of State. "The Atomic Energy Organization of Iran, AEOI. May 11, 1977 http://www.gwu.edu/ nsarchiv/nukevault/ebb268/doc14b.pdf (Accessed April 23, 2011).

${ }^{240}$ New Scientist, "Political Upheavals Hit Iran's Nuclear Program," November 30, 1978: 667.
} 
Ayatollah Khomeini and his allies in the anti-Shah political movements also mounted domestic pressure against the INP. The Ayatollah categorically repudiated the full gamut of nuclear options as un-Islamic, taghooti (idolatrous) and ethically reprehensible white elephant projects.

\section{The India Resemblance Raises More Eyebrows}

As Iran's nuclear enterprise was moving along, the parallels between its nuclear development strategy and those of India were becoming more curious and visible. One of these areas was Iran's keen interest and heavy investment in R\&D that betrayed an Indian connection. At the core of Iran's nuclear R\&D program was an ambitious plan to build the Esfahan Nuclear Technology Center (ENTEC) as the primary center for as diverse functions as nuclear reactor operator training, fuel fabrication, and uranium chemistry.

Modeled after India's Bhabha Atomic Research Centre (BARC), the overall function of the massive facility, containing some 15 buildings, was to maximize the facility, velocity, and scope at which Iran could generate, absorb, or indigenize all manner of nuclear technology. As much as the ENTEC in its entirety raised suspicions in the United States, the main concern of the Americans was the Metallurgy division at the ENTEC whose function was "to study materials to be used in reactors and other facilities in which radioactive substances are manipulated." In U.S. judgment, the ENTEC's inclusion of a "hot cell for handling highly radioactive substances" constituted an important "first step toward a reprocessing facility."241

These concerns came to a sharp relief following a February 1977 tour by an Oak Ridge National Lab (ORNL) delegation of the ENTEC designed by the French

\footnotetext{
${ }^{241}$ From US Embassy Tehran to Department of State. "The Atomic Energy Organization of Iran, AEOI. May 11, 1977; http://www.gwu.edu/ nsarchiv/nukevault/ebb268/doc14b.pdf (Accessed April 23, 2011).
} 
Technicatome Company. The ORNL team couldn't help but notice the similarity in location, sandwiched between two mountains, between the ENTEC facility and the U.S. Sandia Weapons Laboratory. On top of that, in the U.S. delegation's judgment, the facility's "unusually large size" made it technically suitable to "produce weapons-grade plutonium." Based on these disconcerting factors, the U.S. delegation deemed the ENETC facility a potential cause for alarm that merited "watching.,"242

The AOEI's extensive plans to build an extensive manpower base to completely indigenize its technological platform also seemed to have been modeled after India. According to one expert, the AEOI had about 150 personnel with nuclear physics training in 1975 . The number was slated to increase by 100 times to 15,000 , according to one estimate, to indigenously staff the projected nuclear facilities by the mid-1990s. ${ }^{243}$

This goal was pursued vigorously in two phases: identifying and luring nuclear scientists and technicians in Diaspora, especially in the United States, back to Iran and concluding academic cooperation programs with foreign institutions to train Iranian students in the field of nuclear engineering. In the interim, the AEOI started hiring internationally where Iranian nationals were not on hand. As part of implementing the first objective, the AEOI, on Dr. Etemad's initiative, launched a comprehensive program to send Iranian students for training in nuclear engineering to countries as diverse as the USA, the UK, France, Belgium, Austria, Germany, and India.

In 1978, Iran had almost 2000 students in various countries receiving all manner

\footnotetext{
${ }^{242}$ Secret. From US Embassy Tehran to Secretary of State. GOI/AEOI Plans for Isfahan Nuclear Technology Center, ENTEC February 14, 1977 http://www.gwu.edu/ nsarchiv/nukevault/ebb268/doc25b.pdf (Accessed August 6, 2010).

${ }^{243}$ George Quester quoted in Anne Hessing Cahn, "Determinants of the Nuclear Option: The Case of Iran ," in Nuclear Proliferation and the Near-Nuclear Countries (Cambridge, MA: Ballinger Publishing Company, 1975) P 192.
} 
of nuclear training. The most strategic of these relations were the educational and training relations AEOI had established with the Oak Ridge National Laboratory and the MIT. ${ }^{244}$ The relationship with the MIT proved an extremely controversial issue. Modeled on the Indian experiment of establishing a national flagship technical university at Kanpur (IITK or Indian Institute of Technology Kanpur) whose primary purpose was to serve Indian national interests, the AEOI-MIT collaboration, worth $\$ 1.3$ million, was a two-year "special Master's program" to train Iranian students "at a premium." The program, geared toward the technical and HR needs of the AEOI, was devised to train thirty Iranian students every year in cooperation with MIT's Departments of Physics and Nuclear Engineering. The partnership soon infuriated much of the MIT faculty. ${ }^{245}$ Things reached a crescendo when a Computer Sciences professor wrote the polemically titled "Selling MIT: Bombs for the Shah" article in which he argued "the Iranian nuclearengineering students would end up making bombs for the Shah."246 MIT's collaboration with Iran was not limited to the AEOI as, for example, the United States' most advanced missile technology center at MIT's Draper Laboratory was in preliminary talks with Aryamehr University of Technology (AMUT) in Tehran to "to provide a comparable facility" to Iran. ${ }^{247}$

\footnotetext{
${ }^{244}$ From US Embassy Tehran to Department of State. "The Atomic Energy Organization of Iran, AEOI. May 11, 1977 http://www.gwu.edu/ nsarchiv/nukevault/ebb268/doc14b.pdf (Accessed April 23, 2011).

${ }^{245}$ Stuart W. Leslie and Robert Kargon, "Exporting MIT: Science, Technology, and Nation-Building in India and Iran," OSIRIS 21, no. 1 (2006): 110-130.

246 "Education: Pipeline from Iran," Time, April 1975. http://www.time.com/time/magazine/article/0,9171,917345,00.html\#ixzz1Pr8giAwM (Accessed May 24, 2011).

${ }^{247}$ Stuart W. Leslie and Robert Kargon, "Exporting MIT: Science, Technology, and Nation-Building in India and Iran," OSIRIS 21, no. 1 (2006): 110-130.
} 
As a matter of fact, the issue of human resources-- in all aspects of a vibrant nuclear program including nuclear operators, technicians, researchers, and administrators-- was of such a high priority for the AEOI that Eemad, along with two of his most qualified confidants, Mahdi Sarram ${ }^{248}$ and Cyrus Manzour ${ }^{249}$, were in charge of coordinating and streamlining this effort. ${ }^{250}$

\section{AEOI's Strategic Hedging}

As the prospects for the conclusion of a mutually satisfactory agreement between Tehran and Washington were growing dimmer, Iran was stepping up its efforts to reach full-fledged independence in the fuel cycle from whatever source it could lay its hands on. The bulk of this effort was directed toward securing long-term fuel supply sources. In this period, the Shah's nuclear footprint was practically everywhere as Etemad was travelling all over the world to secure nuclear deals, some public, others secret. According to one source, the AEOI had some fifty-four joint exploration projects searching wide and far for uranium across five continents.

The U.S. documents describe the pace and scope of the AEOI's efforts "to procure supplies of uranium and to obtain mining concessions as "feverish." As part of this effort, the AEOI launched a three-year comprehensive uranium-prospecting program

\footnotetext{
${ }^{248}$ Sarram earned a degree in Reactor Engineering from University of Michigan and obtained reactor operator's license from the AEC. He was active in the AEOI's Amirabad Nuclear Research Center. For more see Confidential. Airgram from the US Embassy Tehran to the Department of State. The Atomic Energy Organization of Iran. April 15, 1976. http://www.gwu.edu/ nsarchiv/nukevault/ebb268/doc14a.pdf (Accessed April 14, 2011).

${ }^{249}$ Cyrus Manzoor was in charge of the AEOI's Legal and International Office. He, along with Keyvan Tabari, constituted Iran's negotiating team in concluding a comprehensive nuclear deal with the United States.

${ }^{250}$ Akbar Etemad, Barnameh-ye enerji-ye atomi-ye iran, talash-ha va tanesh-haa (Iran's Nuclear Energy Program, Hopes and Challenges), ed. Gholam Reza Afkhami (Bethesda, MD: Bonyad-e Motale'at-e Iran (Foundation for Iranian Studies) 1997) P165.
} 
conducting aerial radiometric and gravimetric survey of half Iranian territory for economically viable uranium deposits. ${ }^{251}$

Another component of Iran's hedging strategy consisted of adopting a nuclear development policy with maximum supplier diversity. The choice of pressurized water reactors (PWR) over heavy water or boiling-water power stations constituted a significant chunk of this policy. Apart from the technical and industrial advantages of PWRs, as Etemad later explained, the decision was part of a conscious policy to have maneuverability between suppliers: "We have, for instance, made a comparison between light-water power stations and the Canadian heavy-water power stations. The Canadian power stations seemed to us rather more expensive, and there has been less industrial experience with this type of reactor. Furthermore, we would only have had one supplier."252

On the international front, the AEOI concluded agreements with Australia, Gabon and Niger for uranium prospecting. However, arguably the most important aspect of the Shah's strategic hedging effort to secure nuclear fuel supply was focused in South Africa. In 1975, rumors were afloat that South Africa had "negotiated a [secret] agreement with Iran according to which Iran would invest in the South African enrichment project in

\footnotetext{
${ }^{251}$ Akbar Etemad, Barnameh-ye enerji-ye atomi-ye iran, talash-ha va tanesh-haa (Iran's Nuclear Energy Program, Hopes and Challenges), ed. Gholam Reza Afkhami (Bethesda, MD: Bonyad-e Motale'at-e Iran (Foundation for Iranian Studies) 1997) P34.

${ }^{252}$ Foreign Broadcast Information Service (FBIS) Daily Reports, Pairs Le Monde, December 2, 1975, Le Monde Interviews Iranian Nuclear Energy http://docs.newsbank.com/s/HistArchive/fbisdoc/FBISX/11D8BF78E44EC108/0D0CB4F6C367F64A (Accessed August 23, 2011).
} 
return for the enriched uranium" Tehran needed for its nuclear program. ${ }^{253}$ On October 12, 1975 The Washington Post reported that the agreement provided for the purchase of some "\$700 million-worth of uranium from South Africa and put up part of the money for a huge uranium-enrichment plant to be built in South Africa." Following the agreement, speculations were rife that this was the reason why the South African Uranium Enrichment Corporation (UCOR) withdrew from a massive deal with the FRG Company Steag. ${ }^{254}$

Iran's non-compliance with OPEC's oil embargo on South Africa was undoubtedly instrumental in Tehran's nuclear ties with Pretoria. It is worth noting that South Africa in the mid-1970s was deemed by the nuclear expert community a "near nuclear" state on a par with Germany and Taiwan well ahead of Brazil and South Korea. $^{255}$

The AEOI also launched a massive effort to obtain shares in different uranium enrichment joint stock companies. The most important of these was European Gaseous Diffusion Uranium Enrichment Consortium commonly known as Eurodif. In 1975 Iran invested some $\$ 1$ billion to obtain 10 percent share that initially belonged to Sweden in the consortium. This made Iran a stockholder alongside France, Italy, Spain, and Belgium in the France-based facility entitling the AEOI to 10 percent of the uranium enriched at the plant. The financial contribution of the Shah to Eurodif gave Iran "a blocking power

\footnotetext{
${ }^{253}$ International Herald Tribune, October 13, 1975. Quoted in Zdenek Cervenka Barbara Rogers, The Nuclear Axis: Secret Collaboration Between West Germany and South Africa (New York, NY: Times Books, 1978).

${ }^{254}$ Quoted in Zdenek Cervenka \& Barbara Rogers, The Nuclear Axis: Secret Collaboration Between West Germany and South Africa (New York, NY: Times Books, 1978) P329.

${ }^{255}$ Zdenek Cervenka Barbara Rogers, The Nuclear Axis: Secret Collaboration Between West Germany and South Africa (New York, NY: Times Books, 1978).
} 
in the consortium" as "the largest shareholder." This would enable Iran to have a decisive say "on 'sensitive' production lines, in particular those of enriched uranium for military use. ${ }^{256}$ Iran also held a $25 \%$ participation share in another uranium enrichment facility in France named COREDIF. ${ }^{257}$

In June 1974, Iran also signed a liberally articulated blank agreement with France under which the two countries would cooperate, in Etemd's words, on "almost all aspects of the peaceful utilization of nuclear technology." ${ }^{, 258}$ The inking of this Franco-Iranian agreement essentially made Iran the first oil-producing country trying to get a foothold in the elite league of nuclear energy. ${ }^{259}$

As time wore on, Tehran and Paris signed more concretized agreements to operationlize the initial agreement. One of the most important of these was an agreement concluded in November 1974 for the construction of two 900 MWe power plants, to come on stream in 1982 and 1983, on the banks of the Karun River. The Light Water Reactors (LWR) were essentially Westinghouse reactors manufactured under license by Framatome, a French affiliate of the Creusot-Loire. France and Iran also concluded an agreement in May 1975 to build the Esfahan Nuclear Research Center (ENTEC) by 1980.

The ENTEC was conceived by the AEOI to act as "the mainstay of Iran's nuclear energy program." Iran, in Etemad's words, intended to station some 1000 nuclear experts

\footnotetext{
${ }^{256}$ Ali Rastbeen, "The Iranian Nuclear Programme: Process and Legitimacy," in Shia Power: Next Target Iran?, 123-136 (London: Vallentine Mitchell, 2007).

${ }^{257}$ Bijan Mossavar-Rahmani, "Iran's Nuclear Power Programme Revisited," Energy Policy 8, no. 3 (September 1980): 189-202.

${ }^{258}$ Foreign Broadcast Information Service (FBIS) Daily Reports, Paris Le Monde, December 2, 1975, Le Monde Interviews Iranian Nuclear Energy Official. http://docs.newsbank.com/s/HistArchive/fbisdoc/FBISX/11D8BF78E44EC108/0D0CB4F6C367F64A (Accessed August 24, 2011).

${ }^{259}$ New York Times, February 11, 1974.
} 
in the center and use it for "training its team of experts and to perform "operation and maintenance" of power stations. Additionally, the center was planned to be equipped with a Minerva-type research reactor to conduct "research on power reactors, particularly breeder reactors, and for access to installations enabling [Iran] to familiarize itself with fuel cycles." According to Etemad, Tehran was "particularly" interested in manufacturing "the fuel elements of the light-water power stations and learn to handle uranium and plutonium."260

Iran's nuclear ties with Germany didn't hit a major snag like the one with Washington under the Shah either. As a matter of fact, the FRG's close ties with Tehran was an issue of concern in Washington as the Americans were concerned what would happen should Iran enter into a comprehensive nuclear deal with Bonn that included transfer of reprocessing technology, training, and equipment. The issue came up a few times during internal deliberations in the State Department on proliferation and reached a pitch during a July 2, 1976 conversation between the FRG Ambassador to the United States Berndt Von Staden and Secretary Kissinger. The Americans, visibly miffed at the fact that the Germans had not kept them in the loop prior to making a commitment to the Shah on the issue of reprocessing and before signing the FRG-Iranian Agreement for Nuclear Cooperation, let the Ambassador know that the agreement would not be "greeted with enthusiasm by the US." According to the U.S., although Washington was not

\footnotetext{
${ }^{260}$ Foreign Broadcast Information Service (FBIS) Daily Reports, Paris, Le Monde, December 2, 1975, Le Monde Interviews Iranian Nuclear Energy Official. http://docs.newsbank.com/s/HistArchive/fbisdoc/FBISX/11D8BF78E44EC108/0D0CB4F6C367F64A (Accessed August 24, 2011).
} 
looking for "controversy with the FRG," it couldn't avoid registering its displeasure at the agreement. ${ }^{261}$

Toward the late 1970s, the Americans were especially concerned over the issue of spent fuel rods from the four nuclear reactors under contract at Bushehr and Darkhovin. According to one estimate, the combined capacity of the four reactors already under construction (42,00 MWe) would give Iran the capability to "produce enough plutonium to fabricate about a bomb per day" if Tehran acquired reprocessing capability. ${ }^{262}$

Tehran also initiated nuclear cooperation with Japan in the late 1970s. The most important component of Tehran-Tokyo nuclear cooperation materialized in December 1977 with the conclusion of a protocol with a Japanese consortium to construct two "nuclear energy operated water desalination plants" near Bushehr. The plants, to be powered by the nuclear reactors IR-I and IR-II under construction by KWU, would produce "about 100,000 cubic meters of desalinated water daily from the Persian Gulf. This project would make the otherwise desolate city of Bushehr the most large-scale water desalination site in the world. ${ }^{263}$

In the United States, Iran, through its private sector companies, was testing the waters to enter into a joint venture contract for a gaseous enrichment facility with Bechtel, Goodyear, and Williams. Apart from that, the AEOI had visionary plans to

\footnotetext{
${ }^{261}$ Secret. Department of State Memorandum of Conversation. The Secretary's Meeting with FRG Ambassador Von Staden on the FRG/Iran Agreement for Nuclear Cooperation. July 2, 1976. http://www.gwu.edu/ nsarchiv/nukevault/ebb268/doc20.pdf (June 26, 2010).

${ }^{262}$ Anne Hessing Cahn, "Determinants of the Nuclear Option: The Case of Iran ," in Nuclear Proliferation and the Near-Nuclear Countries (Cambridge, MA: Ballinger Publishing Company, 1975).

${ }^{263}$ Foreign Broadcast Information Service (FBIS) Daily Reports, Teheran, December 11, 1977, JapaneseAided Desalination Plants http://docs.newsbank.com/s/HistArchive/fbisdoc/FBISX/11D80855EB7ED3A0/0D0CB4F6C367F64A (Accessed August 15, 2011).
} 
invest in new enrichment technologies like jet nozzle, gas centrifuge and laser enrichment techniques in the United States. ${ }^{264}$

The AEOI also had forged a very close relationship with the Pakistan Atomic Energy Commission (PAEK) both within the multilateral context of the Regional Cooperation for Development $(\mathrm{RCD})^{265}$ and the close bilateral bonds between Mohammad Reza Shah and Zulfikar Ali Bhutto. The center of gravity of this relationship in the nuclear context was the close personal ties between Etemad and PAEK's longtime chairman Munir Ahmad Khan. As Etemad later recounted, the Pakistanis and especially Khan were exceptionally unreserved with the AEOI about divulging their private thinking on the atom and its military applications.

As a matter of fact, Etemad recalls Khan arguing with him that Iran shouldn't be dismissing the military dimensions of a nuclear program out of hand. This was apparently part of Pakistan's tentative plans to foster an intimate and strategic AEOI-PAEK relationship especially in the R\&D sector where the Shah's deep pockets and Pakistan's know-how could generate a symbiotic thrust forward. ${ }^{266}$ A clear indication of this willingness could be traced in Prime Minister Bhutto's courting of the AEOI to jointly operationalize the reprocessing facility Pakistan had signed a contract to obtain from

\footnotetext{
${ }^{264}$ Confidential. Airgram from the US Embassy Tehran to the Department of State. The Atomic Energy Organization of Iran. April 15, 1976. http://www.gwu.edu/ nsarchiv/nukevault/ebb268/doc14a.pdf (Accessed April 14, 2011).

${ }^{265}$ The RCD was a regional economic mechanism established in 1964 between Iran, Turkey, and Pakistan before its dissolution in 1979 and later replacement by Economic Cooperation Organization (ECO) in 1985.

${ }^{266}$ Akbar Etemad, Barnameh-ye enerji-ye atomi-ye iran, talash-ha va tanesh-haa (Iran's Nuclear Energy Program, Hopes and Challenges), ed. Gholam Reza Afkhami (Bethesda, MD: Bonyad-e Motale'at-e Iran (Foundation for Iranian Studies) 1997) Pp 126-127.
} 
France in March $1976 .{ }^{267}$ Islamabad was basically interested in Tehran financing the reprocessing facility to be located on Pakistani territory.

It is noteworthy that although such an arrangement would have jibed rather well with Washington's notion of multinational reprocessing facilities, Etemad was against entering into it particularly if it was located on foreign territory. The other concern Iran raised with the Americans was that Islamabad was actively pursuing a nuclear weapons program Iran had no interest in. ${ }^{268}$

According to Etemad, at the heart of Khan's arguments for strategic partnership with Iran was a longing to create esprit de corps between the two countries against those Western nuclear weapons states that wanted to perpetuate their monopoly on nuclear technology and put it beyond reach for the orient. Etemad later recalled extensive talks with the Shah regarding the feasibility and advisability of fostering such team with Islamabad. HIM's consistent judgment was that the strategic equilibrium of power between Iran, India, and Pakistan was so delicate and fragile that it could not accommodate a close nuclear cooperation between the AEOI and the PAEC. In such an atmosphere, the broader regional considerations forestalled the two countries' nuclear solidarity from going operational despite the fact that Iran kept the communication channels with Islamabad open for contingency and intelligence purposes.

As much as Iran's neighbor to the east was eager to pool resources and join forces with Tehran to put up a united nuclear front, Iran's Baathist adversary to the West was

\footnotetext{
${ }^{267}$ Confidential. Airgram from the US Embassy Tehran to the Department of State. The Atomic Energy Organization of Iran. April 15, 1976. http://www.gwu.edu/ nsarchiv/nukevault/ebb268/doc14a.pdf (Accessed April 14, 2011).

${ }^{268}$ Secret. Memorandum of Conversation. Proposed Cable to Tehran on Pakistani Nuclear Reprocessing. May 12, 1976 http://www.gwu.edu/ nsarchiv/nukevault/ebb268/doc17.pdf (Accessed June 25, 2010).
} 
bent on a keeping its nuclear program as shielded from Tehran's piercing eyes as possible. This was such an unnerving cause for concern for the Shah and the AEOI that Etemad exhorted the French to keep Iran in the loop on Baghdad's nuclear dealings with Paris.

Further afield, the AEOI had also initiated preliminary contacts with China as Beijing in the mid-1970s was exploring the idea of having a nuclear energy program alongside its military program. Etemad recalls that during his visit to China in early 1977 , the Chinese showed great interest in receiving legal, administrative, and logistical advice on how to kick-start a civilian program comparable to Iran's. During the trip, the Chinese, already alienated from Moscow following the Sino-Soviet split of the 1960's, were enthusiastic to test the waters for a strategic cooperation with Tehran as they considered Iran a viable gateway to the West.

As part of its strategic hedging policy, in April 1977, Iran also held an International Conference on Transfer of Nuclear Technology in Persepolis. As mentioned before, the conference, organized by the AEOI (mainly planned by Mahdi Sarram, AEOI Deputy in Charge of Nuclear Safeguards and Training), came right on the heels of President Carter's anti-nuclear energy policy that essentially amounted to a paradigmatic shift in Washington's energy policy away from nuclear technology ${ }^{269}$ especially with regards to "reprocessing of nuclear fuel and fast breeder reactors." As the State Department put it, the conference proved a "historic forum for interchange of views

\footnotetext{
${ }^{269}$ See the transcript of Jimmy Carter's April 18, 1977 televised speech at Jimmy Carter, "The President's Proposed Energy Policy." 18 April 1977. Vital Speeches of the Day, Vol. XXXXIII, No. 14, May 1, 1977, pp. 418-420. http://www.pbs.org/wgbh/americanexperience/features/primary-resources/carter-energy/ (Accessed June 14, 2011).
} 
between nuclear supplier nations and Third World countries." ${ }^{270}$ The architect of the Carter Administrations new nuclear policy, however, was less enthusiastic about the conference. From Joseph Nye's perspective, the conference that “condemned Carter's policies" was essentially an example of the sentiments represented by a momentous "transnational nuclear elite" who were "bitterly opposed" to the change of heart on nuclear energy advocated by the Carter White House. ${ }^{271}$

Perhaps the most proliferation-relevant aspect of the Shah's strategic hedging in this period, however, was going on, under the American radar, between Tehran and Tel Aviv. The secret nuclear cooperation was despite Israel's initial concerns over France's nuclear cooperation with Iran. For instance, in early 1976, Israeli Foreign Minister Yig'al Allen registered Tel Aviv's dissatisfaction over the issue seeking "certain clarifications" from Paris on the transfer of nuclear technology and reactors to Tehran. ${ }^{272}$

The scene started changing toward the late 1970s however, as Tehran and Tel Aviv came to increasingly sympathize with one another's strategic perceptions. According to documents allegedly left behind in Tehran by Israelis following the 1979 Iranian revolution, within an oil-for-arms collaborative arrangement, codenamed Flower, Iran and Israel were jointly cooperating in the development of sophisticated surface-tosurface and submarine-launched missile systems.

\footnotetext{
${ }^{270}$ From US Embassy Tehran to Department of State. "The Atomic Energy Organization of Iran, AEOI. May 11, 1977 http://www.gwu.edu/ nsarchiv/nukevault/ebb268/doc14b.pdf (Accessed April 23, 2011).

${ }^{271}$ Joseph Nye, Power in the Global Information Age: From Realism to Globalization (New York, NY : Routledge, 2004). P4.

${ }^{272}$ Foreign Broadcast Information Service (FBIS) Daily Reports, January 28,1976. Allon: Israel Concerned About Nuclear Help to Arabs. http://docs.newsbank.com/s/HistArchive/fbisdoc/FBISX/11DCF724F3B814F0/0D0CB4F6C367F64A (Accessed August 25, 2011).
} 
According to the records, 1650-pound missiles with a range of 300 miles were scheduled for assembly and test firing near Sirjan in the southern Iranian province of Kerman. The United States was kept so completely out of the loop on the project that, according to a 1986 New York Times articles, U.S. officials in the State Department, the Pentagon, the Central Intelligence Agency and the National Security Council were caught unawares by the revelation of the intimate engagement between Tehran and Tel Aviv on a nuclear-relevant missile technology project.

The remarks made by Harold Saunders, former Assistant Secretary of State for Near Eastern Affairs on the issue couldn't be more revealing: "Israel built a lot of things for the Iranians that we did not know about. But it surprises me that the Israelis would have brought the Iranians into the development of a missile that may have been part of their nuclear program. If that is the case, I am surprised we did not know about it."

The Shah's military confidant General Toufanian was Iran's interlocutor in negotiating the deal with Israeli Foreign Minister Moshe Dayan and Minister of Defense General Ezer Weizmann. Toufanian, recounting his memories after the Iranian revolution, made no secret of the Flower project's special appeal to the Shah because of its nuclear potential. Reiterating Iran's disinterest in a nuclear weapons capability at the time, Toufanian observed, "that did not mean we would not be interested in another decade. ${ }^{273}$

The inclusion of Tehran in Tel Aviv's nuclear doctrine was the ultimate manifestation of the proximity of the Iranians' and Israelis' strategic reading of the Middle East's security environment and power relativities as two strategically lonely

${ }^{273}$ Israeli missile deal with the shah. New York Times, April 1, 1986. http://search.proquest.com/docview/425851373?accountid=10901 (accessed August 1, 2010). 
countries. One could bring into relief the special relation between Iran and Israel in this era by contrasting it to Tel Aviv's vociferous complaints over the decades against provision by the United States to the Middle East Arab states of any ballistic missiles capable of striking Israel. What really makes the Flower project oddly unique, however, is the fact that Israeli officials made a point of letting Iran in on the perfected technology's compatibility with nuclear warheads. Israel's willingness to secretly incorporate the Shah's Iran into the military dimension of its nuclear program, while aware of Washington's hypersensitivity to the issue, has been one of the most intriguing and contradictory aspects of Tel Aviv's attitude toward proliferation in the Middle East.

\section{Conclusion}

In a March 1976 interview with Le Monde, the Shah put his vision regarding the indivisibility of military prowess and economic prosperity in the most categorical terms: "There is no such thing as economic strength without military strength," HIM told Jacqueline Grapin, Le Monde's financial and economic correspondent. ${ }^{274}$ This vision set the broad stage for the initial threat interpretations of HIM's nuclear program.

These proliferation fears were only being accentuated by the Shah's carefully calculated insistence in the following years that he harbored no atomic ambitions, not particularly out of respect for Tehran's contractual non-proliferation commitments, but primarily due to hardheaded pragmatic calculations. HIM's most lucidly articulated position on the issue came during an interview with the BBC's Panorama on December

\footnotetext{
${ }^{274}$ Foreign Broadcast Information Service (FBIS) Daily Reports, Jerusalem Domestic Service, February 8 , 1976

http://docs.newsbank.com/s/HistArchive/fbisdoc/FBISX/11D85309CB0D8F30/0D0CB4F6C367F64A (Accessed August 9, 2011).
} 
13, 1976. Pressed on the question of Iran's future military ambitions, the Shah expressed optimism that Tehran would be the world's most formidable non-atomic power within five years. His Majesty expressed the rationale for this position in the most realistic terms: "I am not thinking of this, because I could never be a first-class nuclear power. I could never be a match. Because the only nuclear power around us with which we could eventually have a clash is the Soviet Union, and what is the use of a few silly little [atomic] bombs against those 50-megaton weapons? I mean it is not an intelligent policy." 275

In another interview with the French Radio in June 1977, the Shah tied Iran's quest for non-nuclear supremacy to a well thought-out Iranian quest to extract extended deterrence from the Western bloc. "My regular army should become so strong that a country with bad designs against us would be obliged to use nuclear weapons to beat us. By using nuclear weapons it would begin a world war, which I believe everyone is trying to avoid." 276

The Shah expressed sentiments along the same lines to his chief civilian nuclear ideologue Akbar Etemad when the AEOI Director pressed him on pursuing a nuclear weapons option during a private meeting: Considering "the geopolitical position of Iran," and its "vital need for the free flow of oil," the Monarch stated, "the military nuclear option would create tensions and upset our foreign policy." The Shah added, however,

\footnotetext{
${ }^{275}$ Foreign Broadcast Information Service (FBIS) Daily Reports, London BBC Domestic Television Service, December 13, 1976, BBC Television Interviews Shah on Oil Prices. http://docs.newsbank.com/s/HistArchive/fbisdoc/FBISX/11D94B6E069DF458/0D0CB4F6C367F64A (Accessed August 17, 2011).

${ }^{276}$ Foreign Broadcast Information Service (FBIS) Daily Reports, Paris Domestic Service, June 14, 1976, Shah Comments on U.S. Arms, Energy Policy, Other Topics http://docs.newsbank.com/s/HistArchive/fbisdoc/FBISX/11D8A6CBC20BC5F0/0D0CB4F6C367F64A (Accessed August 17, 2011).
} 
that the "only factor that may bring about a dramatic change and weaken our position is the acquisition of nuclear weapons by one of the countries in the region."277

If the Monarch's sentiments are to be taken at face value, an all-important question becomes one of how can one satisfactorily explain Iran's seemingly uncompromising attitude toward the Americans on the issue of full fuel cycle? This requires delving deeper into the political psyche of the AEOI especially its chairman Akbar Etemad.

One has to bear in mind that there was a fundamental difference between Etemad's narrative on the nuclear issue and that of the Shah. While His Imperial Majesty had been baptized into the nuclear world through a functional paradigm-- that tended to reduce a nuclear enterprise to its energy, security, and prestige components — in Etemad's view, there was an all-important normative dimension associated with an indigenous nuclear program that required a holistic understanding of such an enterprise; one that was not reducible to its spin-off benefits such as security and the like.

Whatever dividends derivatively accrued from such a holistic enterprise, in Etemad's view, would find their organic context within the country's international placement rather than being subsumed or shaped by it. Based on his later comments on the Islamic Republic era, Etemad thought that such a subsumption had befallen the Iran's post-revolution nuclear program — one consumed by its security implications — since it lacked such strategic forethought and organic contextualization.

From Etemad's perspective, this aspect made national nuclear programs unique cross-generational undertakings whose successful implementation required a broad-based

\footnotetext{
${ }^{277}$ Akbar Etemad, Barnameh-ye enerji-ye atomi-ye iran, talash-ha va tanesh-haa (Iran's Nuclear Energy Program, Hopes and Challenges), ed. Gholam Reza Afkhami (Bethesda, MD: Bonyad-e Motale'at-e Iran (Foundation for Iranian Studies) 1997).
} 
national consensus, a durable unity of purpose, and a hospitable international environment. Such an alignment of the stars, in Etemad's view, was extremely rare especially among Third World countries. Iran under the Shah, in Etemad's judgment, stood at such a historically propitious juncture in the mid-1970s: a moment that might never repeat itself in the future. ${ }^{278}$ As explained in a piece he wrote in the mid $1980 \mathrm{~s}$, embarking on the nuclear enterprise was a multilayered undertaking of "psychological, social, economic, political, and cultural implications" that required a "genuine national mobilization effort."279 As the Islamic Republic's nuclear struggle vividly demonstrated decades later, AEOI chief's judgments were presciently on the mark.

Another way of explaining Iran's diehard and, at times, go-it-alone nuclear attitude under the Shah would necessitate reading it through the prism of the Monarch's close confidants. Based on such a reading, despite the comments by the Monarch to the contrary, the scope, scale, pace, and energetic thrust of Iran's nuclear program from 1974 to 1978 was such that even the innermost circle of Iran's political, scientific, and strategic elite couldn't help but read nuclear weapons ambitions to it.

For example, during an interview in 1987, Fereydun Fesharaki, a well-known economist and energy advisor to the Shah's government revealed a letter he wrote to the Shah counseling, "if he wished to pursue the bomb route, expensive nuclear power plants were not the right way.",280

\footnotetext{
${ }^{278}$ Akbar Etemad, Barnameh-ye enerji-ye atomi-ye iran, talash-ha va tanesh-haa (Iran's Nuclear Energy Program, Hopes and Challenges), ed. Gholam Reza Afkhami (Bethesda, MD: Bonyad-e Motale'at-e Iran (Foundation for Iranian Studies) 1997).

${ }^{279}$ Akbar Etemad, "Nuclear Energy: A Challenge for Industrializing Countries ," in Global Energy Assessment and Outlook (Routledge, 1984).

${ }^{280}$ Washington Post, May 02, 1987.
} 
The Shah's Minister of Court and arguably his most intimate confidant Asadollah Alam also believed that HIM was actively considering the ultimate nuclear option. His posthumously published diary reads "HIM has a great vision for the future of this country, which, though he denies it, probably includes the manufacturing of a nuclear deterrent.,281

In an interview in 1985, Hassan Toufanian, the four-star general in charge of the Shah's military procurement cryptically hinted in the same direction claiming Iran had hatched plans to secure "deterrent weapons" from Israel that he could not disclose, but for which he ordered the shipment of $\$ 260$ million worth of petroleum to Israel. ${ }^{282}$

The shah's Foreign Minister, Ardashir Zahidi, voiced similar sentiments: "The Iranian strategy at that time was aimed at creating what is known as surge capacity, that is to say to have the know-how, the infrastructure, and the personnel needed to develop a nuclear military capacity within a short-time without actually doing so. But the assumption within the policymaking elite was that Iran should be in a position to develop and test a nuclear device within 18 months., 283

These sentiments, especially those expressed by Zahedi, jibe well with the Shah's repeated strategy that he would drift with the nuclear tide in the Middle East broadly conceived. Given the Shah's obsession with having an unmistakable and formidable deterrent posture - in no small part since the Monarch believed that the Middle East

\footnotetext{
${ }^{281}$ Alinaghi Alikhani (Editor, Introduction) Asadollah Alam (Author), The Shah and I: The Confidential Diary of Iran's Royal Court, 1968-77 (New York, NY: I. B. Tauris, 2008).

282 "Hassan Toufanian. Interview recorded by Zia Sedghi, 9 May, 18 \& 19 July 1985, Washington, District of Columbia. Iranian Oral History Collection, Harvard University.," Middle Eastern Division, Widener Library, Harvard College Library, 9 May, 18 \& 19 July 1985, http://nrs.harvard.edu/urn-3:FHCL:628390 (accessed March 10, 2011) Sequence 10, P9.

${ }^{283}$ Quoted in Ray Takeyh, Guardians of the Revolution: Iran and the World in the Age of the Ayatollahs (Oxford University Press, 2009).
} 
Arab states, especially Iraq, were prone to misperception and miscalculated risk-takingone would be extremely hard put not to lace HIM's nuclear program with at least some medium-term potential for weaponization. From that perspective, one could safely argue that Iran's nuclear program following the Indian PNE had a tacit security subtext to it.

Surveying the documents from this era, despite an unfortunate lack of access to the CIA side of the INP story, leads one to the conclusion that the Americans were perceptibly concerned about the sustainability of a purely civilian nuclear program by the Shah considering his progressively assertive and autonomous foreign policy posture, his desire to exercise authoritative leadership domestically, his high-expectation national security psyche, his fascination with procuring the state-of-the-art military hardware, and the inextricable link he systematically drew between military and economic modernization.

On a balanced reading of evidence available and at the risk of taking a step into speculation, a verisimilar judgment on the Shah's nuclear vision in the mid to late 1970s would look something along these lines: faced with the major dilemma of not having the technical know-how to compete with the Indians and Israelis on its periphery while at pains to avoid the appearance of being on a crash course toward nuclearization (that would antagonize the Americans), HIM opted for a two-track policy: aim for maintaining the Middle East a Nuclear Weapons Free Zone (NWFZ) at the doctrinal level while, as an auxiliary insurance policy, build a massive civilian nuclear infrastructure that could derivatively churn out a weaponizable capability in short order.

In other words, the Shah kept the political decision open to revision by pursuing a massive civilian nuclear program (commonly referred to as the Japan option). This 
option, also termed the "breakout capability," entailed possessing all the "knowledge, infrastructure, and materiel, which usually lie beneath the threshold of suspicion, but which can be rapidly adapted or reorganized to allow for weaponization processes to be undertaken.,"284

Related to this, one wonders whether it was conceivable, in the Shah's mind, for Iran to shoulder the responsibility of safeguarding peace and stability in the Middle East without having a nuclear capability especially since Israel and India already possessed that capability. In other words, wouldn't a non-nuclear gendarme in a nuclear environment constitute a contradiction in terms?

Pausing a bit further on the same subject, one also has to bear in mind that despite a progressively rising political temperature over the INP in Washington, only genericlevel concerns comparable to those expressed toward other proliferation-prone US allies were expressed toward Iran. A close scrutiny of the declassified documents indicates that while a comprehensive securitization of Iran as a clear and present proliferation threat was absent from the United States' strategic thinking, the Iranian nuclear program was well on its way in the politicization segment of the securitization spectrum toward the end of the Shah's regime.

In this period, the de-securitizing pressure to the INP was attributable to a systemic-level macro-securitization arch where the US-USSR rivalry subsumed and defined all other security concerns. In other words, the main US-USSR security paradigm exercised such a tight grip on the security culture of the United States in this period that other concerns found prominence only though contextualization in the US-USSR arch

\footnotetext{
${ }^{284}$ CIA. Glossary and Acronyms https://www.cia.gov/library/reports/general-reports-1/iraq wmd 2004/glossary.html (Accessed June 12, 2011).
} 
rivalry and rarely emerged to the surface independently. The INP's under-securitized status in this period was despite the fact that a 1974 Memorandum for Secretary of Defense on the long-term implications of Iran's nuclear program drew a staggeringly sobering picture predicting "the annual plutonium production from the planned 20,000 MW Iranian nuclear power program [would] be equivalent to 600-700 warheads." ${ }^{285}$

In this period, it is also noteworthy that despite the U.S. intelligence community's pinning hopes on Iran's NPT membership to produce a long-term non-proliferation behavior, this assessment is poorly substantiated by the Shah's private and public articulations of what would incentivize or dissuade Iran from seeking a nuclear capability.

As far as the Shah was concerned, that decision would have more proximately been shaped by how Iran interpreted its security environment with the NPT exercising only permissive influence on it. This position of the Shah is in stark contrast to the Islamic Republic's justification for why Tehran would not go nuclear where its inviolable treaty commitments under the NPT assume, at least rhetorically, prominence and the security dividends of nukes are either de-emphasized or downright derided. If this observation holds true, an all-important counterfactual question is whether the Shah's Iran would have withdrawn from the NPT faced with the formidable odds the Islamic Republic's nuclear enterprise has been up against?

\footnotetext{
${ }^{285}$ Confidential. Office of Assistant Secretary of Defense for International Security Affairs to Secretary of Defense, "Nuclear Energy Cooperation with Iran- Action Memorandum," June 1974. http://www.gwu.edu/ nsarchiv/nukevault/ebb268/doc02.pdf (Accessed May 4, 2011).
} 


\section{CHAPTER 4:}

\section{9-1988: NUCLEAR DORMANCY}

With the forward momentum of the AEOI already severely compromised during the transition from Etemad to Ahmad Sotoodehnia, the Iranian nuclear program lapsed into a virtual coma when the Islamic Revolution swept across the country in 1979. Following the toppling of the Shah's regime, the head of the AEOI, Sotoodehnia, was imprisoned for almost four years.

As touched upon before, Ayatollah Khomein's demonizing of the nuclear program as a white elephant project essentially slammed the brakes on an enterprise whose institutionalization on a national scale was far from complete under the Shah. Khomeini's rather categorical renunciation of all matters nuclear arguably deprived the Islamic Republic of much flexibility in reviving the Shah's nuclear energy program. The massive exodus of nuclear scientists following the revolution could also be, at least partially, attributed to the ideological and moral tone of Khomeini's unqualified antinuclear policy that found a rather curious hasty implementation by the Transition Government of Mehdi Bazargan.

The contrast between Ayatollah Khomeni's sentiments on the issue with its straitjacketing impact on Iran's official nuclear discourse and the finesse-saturated statements of Prime Minister Nehru in 1957 is quite revealing. "No man can prophesy the future," the Prime Minister said before adding, "but I should like to say on behalf of any 
future Government of India that whatever might happen, whatever the circumstances, we shall never use this atomic energy for evil purposes."286

In any case, whether one ascribes Khomeini's position to revolutionary fervor, ideological overconfidence, or strategic misguidedness, the founder of the Islamic Republic took away much vital ambiguity from Iran's domestic and international nuclear discourse forcing Tehran to either publicly qualify the founding father's sentiments on the issue or embark on a clandestine path in the years ahead. In reality, Tehran opted for a little bit of both, a policy that, retrospectively viewed, proved an ill-conceived combination as it exposed glaring contradictions between Tehran's discourse and behavior and gave rise to a massive and growing trust deficit between Iran and the international system.

In those heady days following the revolution, under the Interim Government of Iran established under the premiership of Mehdi Bazargan in 1979, a petroleum geologist by the name of Fereydoun Sahabi was placed at the helm of an anemic AEOI. Almost immediately after assuming office, Sahabi launched a scathing criticism of Iran's nuclear enterprise under the Shah. Taking to task the activities of the AEOI under the previous regime as "directed improperly in order to create a consumer market for the industrial products of other countries in Iran," he emphasized that in the future, "no foreign manpower will be utilized in the AEOI."287 Sahabi went on even further questioning the

\footnotetext{
${ }^{286}$ Amitabh Mattoo David Cortright, "Indian Public Opinion and Nuclear Weapons Policy," in India and the Bomb: Public Opinion and Nuclear Options, ed. David Cortrigh and, 3-22 (Notre Dame, Indiana : University of Notre Dame Press, 1996).

${ }^{287}$ Foreign Broadcast Information Service (FBIS) Daily Reports, Tehran Domestic Service April 9, 1979, Atomic Energy Organization Projects to be Discontinued, http://docs.newsbank.com/s/HistArchive/fbisdoc/FBISX/11DAADE45FC76810/0D0CB4F6C367F64A (Accessed October 13, 2011).
} 
very raison d'être of the AEOI as an organization "imposed upon the Iranian people" "in the wake of the former regime's modernization policy." ${ }^{288}$ These sentiments naturally translated to a wholesale nuclear de-mobilization in the months ahead.

In such an atmosphere, on July 31, 1979 head of KWU office in Tehran, Norbert Schmitt announced the company's unilateral withdrawal from the two nuclear power plants in Bushehr. The KWU letter addressed to the AEOI mentioned that the German company "no longer felt bound by the contract" it had concluded with Tehran. ${ }^{289}$

Following the KWU announcement and caught up in the revolutionary fervor of the time, Abbas Taj, Iranian Minister of Energy cast aspersions on the contract the AEOI had concluded with KWU: "Because this contract was not in Iran's interests; because implementation of the contract would have made [Iran] dependent on outside sources from the standpoint of technology, raw materials, and foreign engineers; and since the contract embodied colonialist features and had not been formulated in Iran's interests, it was therefore rejected by the Iranian Government." 290 Tehran estimated the damage

\footnotetext{
${ }^{288}$ Foreign Broadcast Information Service (FBIS) Daily Reports, Tehran Domestic Service April 9, 1979, Atomic Energy Organization Projects to be Discontinued, http://docs.newsbank.com/s/HistArchive/fbisdoc/FBISX/11DAADE45FC76810/0D0CB4F6C367F64A (Accessed October 13, 2011).

${ }^{289}$ Foreign Broadcast Information Service (FBIS) Daily Reports, Hamburg DPA, July 31, 1979, KWU Official Confirms Withdrawal From Nuclear Plants. http://docs.newsbank.com/s/HistArchive/fbisdoc/FBISX/11DA94BA4D12DCE0/0D0CB4F6C367F64A (Accessed October 4, 2011).

${ }^{290}$ Foreign Broadcast Information Service (FBIS) Daily Reports, Tehran Domestic Service, August 1, 1979, Minister on Pro Firm's Termination of Nuclear Plant Contract. http://docs.newsbank.com/s/HistArchive/fbisdoc/FBISX/11DA6F95EFCB2350/0D0CB4F6C367F64A (Accessed October 8, 2011).
} 
inflicted by the KWU withdrawal at DM 5 billion claiming financial compensation by the German company. ${ }^{291}$

Soon after the termination of the KWU deal, in February 1980, Sadegh Ghotbzadeh, Iranian Foreign Minister and one of the most vocal anti-nuclear hawks in the transition government, announced Tehran's desire to withdraw from the Eurodif consortium in line with Iran's strategy to scrap all its nuclear energy involvements. Following those remarks, French Minister of Industry Andre Giraud announced that Paris would not reward Iran's unilateral pullout and would not "refund" Tehran's share of the enterprise. $^{292}$

Although the Islamic Republic's rather impulsive decision to make a u-turn on the Shah's nuclear energy policy de-nuclearize its energy sector enjoyed initially strong ideological and some pragmatic support on the domestic scene, the experts closely analyzing Iran's future energy trends predicted a return to the Shah's paradigm sooner or later. Manour Kashfi, for instance, argued as early as 1980 that the structural economic imperatives on the ground would propel Iran, over the next two decades, towards resuscitating the previous regime's nuclear energy program. ${ }^{293}$

These sentiments proved prophetic as barely two years into the repudiation of all matters nuclear the initial signs of a change of heart on the issue appeared in Tehran. In

\footnotetext{
${ }^{291}$ Foreign Broadcast Information Service (FBIS) Daily Reports, Tehran Domestic Service, August 10, 1979, FRG Should Compensate For Cancellation of Nuclear Contract. http://docs.newsbank.com/s/HistArchive/fbisdoc/FBISX/11DA979427C03948/0D0CB4F6C367F64A (Accessed October 9, 2011).

${ }^{292}$ France Denies Iran a Refund. 1980. New York Times Feb 19, 1980. http://search.proquest.com/docview/121335416?accountid=10901 (accessed July 28, 2011).

${ }^{293}$ Kashfi, Mansour S. 1980. The Energy Alternative for Iran's Future: Nuclear power. IMPACT 30, (3): 217-217-222, http://search.proquest.com/docview/61146452? accountid=10901 (accessed July 28, 2011).
} 
May 1981, for example, at the initiative of the AEOI, a seminar in Isfahan was held to investigate the construction of nuclear power plants in Iran. The range of issues covered in the papers presented-including economic necessity, technological feasibility, safety issues, full fuel cycle, training and manpower-demonstrated the AEOI's newfound interest to put the Shah's program back on track. ${ }^{294}$

Shortly following that, in March 1982, the head of the ENTEC in the city of Isfahan made headlines going public with the Islamic Republic's plans to make a foray into the field of nuclear technology. ${ }^{295}$ Iran's interest in nuclear technology was decidedly on an upward moving trajectory now. In May 1982, the AEOI's Nuclear Research Center sponsored a conference entitled "Radioisotopes Seminar and Its Application in Science, Medicine, Agriculture and Industry" where non-energy benefits deriving from the atom were also brought to the fore. ${ }^{296}$ It is important to bear in mind here that lacking a ringing endorsement by Ayatollah Khomeini as a national priority, the Islamic Republic's initial attempts at following in the Shah's nuclear footsteps were few and far from being linear and systematic until the mid 1980s.

\footnotetext{
${ }^{294}$ Hariri, A., R. Khonsari Moosavi, J. Shoai-Naini, and M. A. Motamedi. 1982. Abstract of articles presented at the seminar of investigating the construction of nuclear power plant in Iran. Performer: Atomic Energy Organization of Iran, Tehran. January 1982.35p.Report: AEOI-129, CONF-8105194-ABSTS, http://search.proquest.com/docview/86233463?accountid=10901 (accessed July 28, 2011).

${ }^{295}$ Reuters. 1982. Iran to Restudy A-power. New York Times, March 18, 1982. http://search.proquest.com/docview/424317436?accountid=10901 (accessed July 28, 2011).

${ }^{296}$ Abstract of articles of radioisotopes seminar and its application in science, medicine, agriculture and industry held at nuclear research center of atomic energy organization of Iran from 29-31, may, 1982. 1982. Performer: Atomic Energy Organization of Iran, Tehran. Nuclear Research Centre.1982.81p.Report: INIS$M F-7519, C O N F-8205146-A B S T$, http://search.proquest.com/docview/86233516?accountid=10901
} (accessed July 28, 2011). 
According to a nuclear energy expert quoted in a 1988 intelligence report, the decision to discontinue the Shah's ambitious nuclear program was taken in light of the fact that it would be "ridiculous to continue a program that depended totally on foreign expertise." The report, however, went on to warn that the infrastructural and scientific foundation developed by the Shah would facilitate the Islamic Republic to move towards developing a nuclear weapons capability. ${ }^{297}$

This ideological diagnosis for termination of the program is radically different from the more pragmatic one argued by Fereydoon Sahabi who later claimed the program was simply not sustainable for a post-Revolution Iran in dire financial straits. Sahabi, who broke his almost three-decade silence on the Interim Government's nuclear policy in 2007, dismissed the conventional wisdom that Bazargan and his technocrat protégés had fundamental anti-nuclear energy predispositions. While explicitly endorsing the common perception that neither Bazargan's nor Rajai's cabinets had any clear understanding as to the wisdom of initiating a nuclear program in the first place, Sahabi's remarks reflect a highly skeptical attitude by both Prime Ministers toward the real value of maintaining a highly capital-intensive nuclear energy program for an oil-rich country.

The first chairman of the post-revolution AEOI claimed, however, that he left no stone unturned, under the most unenviable financial and political circumstances, to salvage what precious little he could of the Shah's program. Up against insurmountable financial odds domestically and political challenges internationally, Sahabi put together a 20-page report on the AEOI's state of affairs to discuss with Bazargan. Upon a critical

\footnotetext{
${ }^{297}$ Secret. Director of Intelligence. Middle East-South Asia Nuclear Handbook May 1988. http://www.foia.cia.gov/docs/DOC_0001033097/DOC_0001033097.pdf (Accessed April 17, 2011)
} 
assessment of the situation, the Prime Minister's directive for Sahabi was to trim the AEOI down to a manageable and sustainable scale.

Following the instructions by the Prime Minister, the AEOI, after much discussion with the nuclear and energy expert community decided on forging ahead with Bushehr power plants and scrapping all other projects. Chief among the withdrawn commitments, on seemingly budgetary grounds, were two 900 MWe power plants under construction on the Karun River by Framatome. ${ }^{298}$ However, as mentioned earlier, at this point in July 1979, a frustrated KWU had already suspended work on the Iran-I and IranII projects in Halileh citing payment arrears and lack of a credible negotiating partner in Tehran.

Such sweeping divestment by the Bazargan Interim Government in the energy sector has long been a contentious issue in the Islamic Republic's domestic political debate. Sahabi's disarmingly simple response to criticisms was that, in the final analysis, Etemad's AEOI had simply bitten off more than it could chew and the bottomless pit the AEOI created under the Shah was not sustainable with dwindling oil revenues. There were reports after the revolution, for example, that the real cost of building the projected 20 power plants would have well exceeded, by possibly three times, the official forecast of $\$ 30$ billion. $^{299}$

In this period, it is curious to note that even though the U.S. officials acknowledged Ayatollah Khomeini's termination of the Shah's nuclear program as a

\footnotetext{
${ }^{298}$ Fereydoun Sahabi, interview by Sergei Barseghian, , Nagoftehayi az tatili-ye barnameh-haye hasteh-iye Iran (The Untolds of the Abandoning of the Iranian Nuclear Program), (September 7, 2007). http://www.aftabnews.ir/prtflxdv.w6dtvagiiw.html (Accessed April 23, 2011).

${ }^{299}$ Rouhollah K. Ramazani, The United States and Iran: The Patterns of Influence (New York, NY: Praeger Publishers, 1982).
} 
"satanic" enterprise, the remote likelihood that the Islamic Iran might have gained the equipment and know-how for uranium enrichment with laser beams made the headlines on August 22, 1979..$^{300}$ This hyped reaction was the earliest indication of how the change in the nature of political regime in Tehran had altered the United States' reading of Iran's dabbling with the atom and Washington's threat perceptions about it.

Washington's inflationary threat perception of the INP only continued to intensify in the following years in the face of physical evidence that Tehran had almost completely abandoned all nuclear enterprises. For instance, the US State Department suggested as early as October 1980, following the bombing of Iraq's nuclear complex by Tehran, that Iran, along with Iraq, Pakistan, and Libya, was "bent on" developing a nuclear weapons capability. ${ }^{301}$ This was followed by a 1982 U.S. intelligence survey that included Iran among 31 countries who would be "able to produce nuclear weapons by the year $2000 ., 302$

With threat judgments on the INP constantly escalating in the absence of a factual grounding, the difference in the modality of securitization pre- and post-1979 revolution was crystallizing in the 1980s. The gist of the difference was that if under the Shah's rule, Tehran's nuclear enterprise was designated as a proliferation challenge at the level of physical capabilities, under Khomeini's regime the threat-designation bar was set at the

\footnotetext{
${ }^{300}$ The Los Angeles Times, August 22, 1979. A3.

${ }^{301}$ Burt, Richard. 1980. A New Type of War? News Analysis. New York Times, Oct 07, 1980. http://search.proquest.com/docview/424000537?accountid=10901 (accessed July 28, 2011).

${ }^{302}$ Richard Halloran, Special to the New York Times. 1982. Spread of nuclear arms by 2000 is seen. New York Times, Nov 15, 1982. http://search.proquest.com/docview/424479455?accountid=10901 (accessed July 28, 2010).
} 
mere level of scientific know-how. Within the new paradigm in the making, the combination of the atom and Islam was viewed and internalized as an explosive cocktail worth moving heaven and earth to deter and defer at almost any cost. For the United States, Khomeini's Iran was the manifestation par excellence of such a baleful eventuality if it got around to gaining nuclear capacity. Almost two decades later in October 2007, President Gerorge Bush most explicitly articulated this hyper-securitized paradigm, "If you're interested in avoiding World War III, it seems like you ought to be interested in preventing them [Iranians] from having the knowledge necessary to make a nuclear weapon."303

A side-effect of the premature securitization of the Islamic Republic's nuclear behavior was the gradual formation and institutionalization of a conceptual framework within the new regime's elite that the United States would have either embraced a nuclear Shah or at least looked the other way if he was hell-bent on going nuclear. This paradigm either explicitly or tacitly is predicated upon a set of perceptions well ingrained in Iran's establishment elite ever since. The first taken-for-granted perception is that Washington was willing to extend to the Shah the "Israel treatment." In the Iranian establishment elite's judgment, this would translate into an either sympathetic or apathetic posture toward a proliferating Shah. As evident from the previous chapter, the declassified evidence on the United States' nuclear approach toward the Shah hardly substantiates such a narrative.

Second, they point at Western Europe's expansive cooperation with the AEOI and the U.S. nuclear industry's chomping at the bit to secure lucrative nuclear deals with Iran. From the pot-revolutionary Tehran's vantage point, the fact that Washington blessed

${ }^{303}$ Quoted in George W. Bush, Decision Points (New York, NY: Crown Publishers, 2010). 
these deals, full well aware of their undeniable proliferation implications, indicates a certain level of receptivity toward a nuclear Iran under the Shah.

Last, and perhaps most important, the Iranians believe that it was inconceivable for a megalomaniac Shah to stand idly by while Islamabad, whom HIM considered Iran's junior partner, acquired nuclear weapons. Iran's senior nuclear negotiator under President Khatami was so convinced of this counterfactual that in 2010 he claimed, "the Shah's ultimate goal was gaining nuclear weapons capability and if he was still in power, Iran's nuclear arsenal would be comparable to that of India and Pakistan."304 As evident in Mouavian's remarks, in the Islamic Republic's judgment, premised upon a purportedly unimpeachable truth that the Shah had proliferation intentions, Ayatollah Khmeini's unequivocal renunciation of the atomic program was a counter-nuclear move of the highest order that effectively pulled Iran back from the proliferation precipice in 1979 . This counter-proliferation move, however, failed to generate any de-securitizing dividends for Tehran in Washington.

With the current of Tehran-U.S. relations rapidly and irreversibly drifting to the security zone, the context of the Islamic Republic's nuclear activities was further securitized in November 1979 with the storming of the U.S. Embassy in Tehran, apparently with Ayatollah Khomeini’s implicit blessing, and the ensuing 444-day hostage crisis. This event had massive implications for Iran's subsequent nuclear activities, not least since it drastically undercut the credibility and inviolability of Iran's commitments to its international contractual obligations like the NPT.

\footnotetext{
${ }^{304}$ Hossein Mousavian, Iran's Nuclear Diplomacy and the Roadmap to Weather the Crisis (Diplomasi-ye Hasteh-iye Iran va Naqsheh-ye Rah baraye Hall-e Bohran), February 25, 2011, http://www.ilna.ir/newsText.aspx?id=182017 (accessed May 14, 2011).
} 
In the eyes of the international community, the embassy takeover was a vivid manifestation that the Islamic Republic was willing to match its unorthodox rhetoric with deeds. From that perspective, the embassy takeover demonstrated the kind of international irresponsibility the new Iranian regime was capable of and "provided some serious grounds for concern about long-term proliferation problems in this country." ${ }^{305}$ With this broad context taking root in the international system and reinforced by Iran's removal from the Western bloc (that exerted considerable dampening pressure on the public designation of Tehran as a proliferator under the Shah), the slightest sign that the Islamic Republic might pick up the nuclear baton where the Shah had left off was almost inevitably to be treated as a credible international proliferation threat.

One would be well advised, however, not to read Iran's commitment to its international contractual obligations exclusively through the prism of the embassy takeover. More panoramically viewed, for example, one could argue that the domestic psychological and normative inhibitions against breaching the non-proliferation regime were probably at their lowest in the years following the Iranian Revolution, particularly after the embassy takeover and during the Iran-Iraq war. There is no evidence, however, to suggest that the withdrawal from the NPT was considered as a viable option in the Iranian national security apparatus in this era.

Another enduring legacy of the embassy takeover with some massive spin-off impact on the future unfolding of the INP was the introduction and, over time, normalization of an ever broadening, deepening, and tightening sanctions regime against

\footnotetext{
${ }^{305}$ National Academy of Sciences (U.S.) Committee on International Security and Arms Control, Nuclear Arms Control: Background and Issues (Washington, D.C. : Committee on International Security and Arms Control and National Academy of Science, 1985).
} 
the Islamic Republic by successive US administrations. ${ }^{306}$ This was a policy decision that, in the judgment of many Iran observers, drastically transformed the direction and tenor of the Iranian Revolution and the behavior of the Islamic Republic.

In any case, as the hostage crisis between Tehran and the United States was raging on, Saddam's Ba'ath regime unleashed a massive military strike against Iran in September 1980. Merely a few days after the breakout of the war, the first nuclear related incident in the life of the Islamic Republic transpired. On September 21, 1980, two Iranian F-4 Phantoms struck Iraq's 40-megawatt thermal (MWth) reactor on the outskirts of Baghdad. Although Tehran scored a significant intelligence and a consequential symbolic hit by inflicting some damage on the laboratories and other supporting facilities, the reactor building escaped the attack mostly unscathed. ${ }^{307}$ The modestly successful attack, the first military strike against a nuclear reactor ever, was completed in a secretly coordinated Iranian-Israeli surgical operation conducted in June 1981 by a squadron of IAF F-16As. ${ }^{308}$

On October 23, 1983 another turning point with strategic implications for the INP took place in Lebanon. On this day, Hezbollah, a newly created Shia militant group inspired by the revolutionary Iran, attacked the barracks of the peacekeeping Multinational Force in Lebanon killing 299 U.S. marines and French servicemen. These attacks marked the initiation of the triangulation of Iran's nuclear efforts by terrorism through Tehran's overseas proxies.

\footnotetext{
${ }^{306}$ For a brief historiography of U.S. sanctions against Iran, see Elaine Morton, Herman Franssen, "A Review of US Unilateral Sanctions Against Iran," The Middle East Economic Survey, August 26, 2002.

${ }^{307}$ Bennett Ramberg, Nuclear Power Plants as Weapons for the Enemy: An Unrecognized Military Peril (Berkeley, CA: University of California Press, 1985).

${ }^{308}$ Trita Parsi, Treacherous Alliance: The Secret Dealings of Israel, Iran, and the United States (Yale University Press, 2007).
} 
Out of this triangulation emerged the applicability to the INP of the concept of "nuclear terrorism" as an asymmetric strategy that would purportedly grant countries like Iran a comfort zone to pull off unconventional attacks on the west (using their non-state clients) with plausible deniability. Arguably, the most consequential and enduring impact of Tehran's intimate association with these non-state actors was its deleterious impact on Iran's deterrability as a responsible rational state in a nuclear context.

In other words, the argument went, since these non-state actors had no territorial return address (a most fundamental imperative for deterrence to emerge and take hold) Tehran could transfer its nuclear capability to these extreme risk takers and challenge the very foundations of the doctrine of mutual nuclear deterrence. "Nuclear blackmail" was the terminology of choice to capture the essence of the new reality. Over the years, the Islamic Republic's failure to either rhetorically or operationally distance itself from these violent non-state actors (VNSAs) as its nuclear capabilities were advancing did little to inspire confidence in Tehran's nuclear trustworthiness and its future deterrence credentials.

In parallel with Tehran's involvement through Hezbollah in Lebanon increasing came a major turn in the tide of Iran-Iraq War in favor of Tehran in 1982 and 1983. The Reagan Administration, concerned over the prospect of a strategic decisive victory by Tehran and its unexpected progress in the war effort, unleashed a new round of sanctions regime known as Operation Staunch. Within this new policy framework Secretary of State George Schultz urged U.S. embassies to put pressure on the host countries to curtail the transfer of arms and dual-use equipment to Iran. This shift in policy came on the heels of a decision by Washington in the previous year to lift dual-use sanctions on Iraq and 
provide Saddam with ISR (Intelligence, Surveillance, and Reconnaissance) support.

Operation Staunch, imposed at the height of Iran-Iraq war, exercised an enduring grip on how Tehran later came to perceive U.S. sanctions regime against itself. From this perspective, an ever-expanding sanctions regime was internalized as an inalienable part of Iran-U.S. relations in the post revolution era (that was only incidentally connected to Iran's nuclear program) whose ultimate objective was to bring about regime change in Tehran.

\section{Securitization of the INP Gains Momentum}

On April 24, 1984 the authoritative Jane's Defense Weekly quoted some unidentified West Germany intelligence sources as saying that Iran had entered the "final stages" of gaining a nuclear capability that had put it a mere two years away from the bomb. ${ }^{309}$ Although the British publication's claim was immediately countered by the U.S. State Department as "unlikely,"310 it set in motion a never-ending trend of putative projections by different intelligence agencies-- ranging from a few months to a decade-on what kind of timeframe stood between Iran and the bomb. "We believe it would take at least two to three years to complete construction of the reactors at Bushehr," the State Department stressed, adding that Bushehr's light water reactors were not "particularly well-suited for a weapons program." The State Department concluded by emphasizing, "There was no evidence of Iranian construction of other facilities that would be necessary to separate plutonium from spent reactor fuel. ${ }^{\text {311 }}$ The Jane's article was apparently based

\footnotetext{
${ }^{309}$ The Los Angeles Times, April 25, 1984. B.4.

${ }^{310}$ The Telegraph, April 26, 1984.

${ }^{311}$ Quoted in The New York Times, April 26, 1984. A.3
} 
on reports that West Germany's KWU had started "preliminary assessment" of the feasibility of completing the two Bushehr reactors, a prospect pronounced highly unlikely by the FRG officials with the Iran-Iraq war still in full swing.

The Jane's article, however, brought some clarity and a foretaste of what was to come to Washington's approach toward Iran's nuclear status as an NPT member state. The U.S. State Department cited the Iranian Government's "previous actions" as a ground that Tehran's pledge to abide by its "international commitments" was less than complete. The DoS specified Iran's state of war with Iraq as intensifying those concerns. Out of these set of anxieties emanated a policy articulated as the following: "the United States will not consent to the transfer of U.S.-origin nuclear equipment, material or technology to Iran, either directly or through third countries, where such consent is legally required." Within this framework, the United States also discouraged "other nuclear suppliers" from engaging in nuclear cooperation with Iran. ${ }^{312}$

Faced with such inhospitable circumstances, Iran's initial attempts to rekindle the Shah's nuclear attempt were focused on Bushehr. Having realized that keeping the BNPP mothballed meant the waste of billions of dollars of capital already sunken, Tehran turned to a host of countries to complete the Busher-I reactor. Chief among these states, initially, were Argentina and China. Argentina had had a long history of working with the Shah's program and had also helped Iran “convert Tehran's Research Reactor from highly enriched uranium (93 percent) to low-enriched uranium fuel and later supplied 20percent-enriched fuel under international safeguards." China, according to a nuclear cooperation agreement concluded in 1987 would help Iran with "scientific exchanges and

\footnotetext{
${ }^{312}$ U.S. Urges Ban on Atom Sales to Iran. New York Times, Apr 26, 1984.
} http://search.proquest.com/docview/424960468? accountid=10901 (accessed July 28, 2011). 
the eventual purchase of miniature neutron source reactors and a heavy-water research reactor." ${ }^{313}$ Iran's first multiple covert and overt attempts to resuscitate the BNPP with various countries were turned down, however, in no small part, under the U.S. pressure.

Realizing the inhospitable international ground and feeling left to its own devices, Iran set out to take a leaf out of Pakistan's book by finagling its way into the nuclear club through securing individual hardware and software components (or components of components, for that matter) in whatever way possible. This was a policy that triggered a long Whack-A-Mole between Tehran and Washington that has continued ever since the mid-1980s.

According to US intelligence sources, Iran terminated the revolution-induced hiatus in its nuclear program in 1982 by attempting to " resurrect at least part of the Shah's ambitious nuclear power plans" especially the BNPP and "a pilot-scale fuel fabrication plant and heavy water facility." ${ }^{314}$ According to this analysis, the Islamic Republic reinstituted the program by picking up where the Shah had left off and trying to build upon the existing infrastructural and scientific foundations. The program was reinstituted apparently with Ayatollah Khomeini's blessing under the supervision of Mir Hossein Mousavi. This report makes it explicit that Mousavi was not pushing for the development of a nuclear weapons program. During this era, the Atomic Energy Organization of Iran (AEOI) continued to oversee all elements of Iran's nuclear program and reported directly to Prime Minister Mousavi.

${ }^{313}$ Secret. Director of Intelligence. Middle East-South Asia Nuclear Handbook May 1988. http://www.foia.cia.gov/docs/DOC_0001033097/DOC_0001033097.pdf (Accessed April 19, 2011).

\footnotetext{
${ }^{314}$ Secret. Director of Intelligence. Middle East-South Asia Nuclear Handbook May 1988. http://www.foia.cia.gov/docs/DOC_0001033097/DOC_0001033097.pdf (Accessed April 19, 2011).
} 
The Islamic Republic faced an uphill battle in pursuit of the Shah's nuclear program, however. Two factors were of paramount significance here: one was the revolutionary elite's continued disdainful and dismissive attitude towards the Shah's program. Under these circumstances, breathing life into the discarded program was a most formidable task. An enfeebled economy further compounded by Tehran's revolutionary excesses and its confrontational foreign policy provided for the most disagreeable atmosphere for a normal nuclear awakening in the post-revolutionary Iran. Second, was the fact that Iran's post-revolution nuclear consciousness was born and cultivated in the middle of the Iran-Iraq War with the international cards decidedly stacked against it. This second war factor had undeniable implications for the subsequent ease with which Iran's nuclear effort, even the most innocuous aspect of it (the Bushehr Nuclear Power Plant), was securitized. In other words, the war atmosphere granted credence and credibility on the claims that Iran, at a minimum, was seeking a nuclear deterrent capability and no aspect of Iran's nuclear program could be de-contextualized and disengaged from this broader fact. This prevailing theme essentially turned every aspect of Iran's nuclear program into a proliferating behavior in the eye of the Western countries.

It was in this atmosphere that in June 1985, Iranian Majlis Speaker Akbar Hashemi Rafsanjani's Beijing visit --the first to a non-Muslim country by a high-ranking Iranian official since 1979-- triggered speculation about Iran's secret nuclear dealings with China. It is important to note here that by the mid-1980s China had replaced France as Washington's country of concern in transfer of sensitive proliferation-relevant technology to Third World countries. These allegations were floated within the context of 
China's apparently rogue proliferation behavior. The United States was concerned that a secret deal had been struck with Iran despite Beijing's conclusion of a nuclear cooperation agreement with the Reagan Administration. The Americans viewed their April 1984 deal with China as a persuasive mechanism to bring China's sensitive nuclear technology transfer in line with international non-proliferation norms and regimes and Beijing's eventual accession to the NPT. This took place in 1992.

These concerns re-intensified in October 1985 when the U.S. intelligence community alleged that China was providing nuclear technology to Tehran. The intelligence reports substantiated allegations already going around in Washington that China was sharing sensitive proliferation-prone knowhow with, in Californian Senator Alan Cranston's words, "five nuclear outlaw" states- Argentina, Brazil, Iran, Pakistan, and South Africa. ${ }^{315}$

As proved to be the case in numerous other proliferation disputes between Beijing and Washington, the two capitals seemed to be on different pages on the all-important question of what constituted nuclear proliferation and what a solid non-proliferation posture required. Put crudely, China believed that conforming to the United States' highly broad definition of proliferation could hurt its commercial interests at a crucial juncture when Beijing was making a calculated and deliberate foray into the marketbased international economy.

In the meantime, the U.S. intelligence community's proliferation concerns were not even widely shared by the Reagan Administration whose senior officials were at pains to portray China as part of the solution, not part of the problem, in Washington's

${ }^{315}$ The Telegraph, October 24, 1985. 
international counter-proliferation efforts. A senior US official, for instance, openly countered Senator Cranston's sentiments claiming China had effectively reversed its attitude toward proliferation. "China used to think proliferation was good because it undermined the hegemony of the two superpowers," the official observed, concluding; "now it thinks proliferation is bad." ${ }^{\text {"16 }}$ A Chinese Foreign Ministry statement promptly rejected Cranston's allegations categorically denying any nuclear relationship between China and Iran. ${ }^{317}$

In this connection, it is important to note that the U.S. intelligence community, by its own admission, did not have a good grasp on China's proliferation behavior before it formally acceded to the NPT in March 1992. The U.S. viewed this as a sign that the Chinese were not entirely a bona fide partner in enforcing their arms control vision yet careful enough not to alienate the Americans. ${ }^{318}$ Much to the chagrin of the United States, this "juggling strategy" by China remained a perpetual feature of the Chinese approach toward cooperation with Iran on the nuclear issue over the years to come.

At the end of this era, Khoemini's death opened up the possibility for a wholesale change of heart and a reboot in the INP. Iran's relations with the Soviet Union, which had been strained and surly, if not outright antagonistic, also started to thaw. A fair chunk of

\footnotetext{
${ }^{316}$ Toth, Robert C. 1985. China: Cranston Cites Nuclear Exports China Exports Nuclear Items, Cranston Says. Los Angeles Times, Oct 21, 1985. http://search.proquest.com/docview/292206763?accountid=10901 (accessed August 1, 2010).

${ }^{317}$ China denies atom aid to Iran And south Africa. New York Times, Oct 25, 1985. http://search.proquest.com/docview/111124204?accountid=10901 (accessed August 1, 2010).

${ }^{318}$ Secret. CIA China Desk. Memorandum for the Record. Beijing's Middle East Proliferation Activities. January 31, 1992. http://www.foia.cia.gov/docs/DOC_0001247931/DOC_0001247931.pdf (Accessed April 17, 2011).
} 
credit for the rapprochement should go to Rafsanjani whose presidency marked the era when Iran embarked on de-ideaologizing its relations with the Soviet Union. It is important to note that Rafsanjani's success on this score was facilitated significantly "with the fallout from the Rushdie affair holding up the normalization of Tehran's ties with the West, [and when] the USSR found itself, at least temporarily, with a relatively clear field ahead for increasing its influence in Iran. ${ }^{319}$ The BNNP reactor came to symbolize this relationship with Iran and Russia formally starting nuclear cooperation in 1992.

It is also important to note that the United States, even before Khomeini's death, viewed the Ayatollah's January 1989 letter to Gorbachev ${ }^{320}$ as indicative of "his approval of the warming trend already underway" signaling "Moscow that Tehran no longer regarded ideological differences as a major barrier to expanding political and economic relations. ${ }^{.321}$ One noticeable element in the U.S. intelligence community's reading of the evolving relationship between Iran and the USSR in 1989 was a conspicuous lack of mention of the nuclear field for potential future cooperation between Tehran and Moscow. $^{322}$

\footnotetext{
${ }^{319}$ Level of Classification Redacted. Central Intelligence Agency. Director of Intelligence. Soviet-Iranian Relations After Khomeini. June 23, 1989 http://www.foia.cia.gov/docs/DOC_0000602666/DOC_0000602666.pdf (Accessed April 18, 2011).

${ }^{320}$ Mohiaddin Mesbahi, "Eurasia between Russia, Turkey and Iran," in Key Players and Regional Dynamics in Eurasia The Return of the 'Great Game', 164-192 (London: Palgrave Macmillan , 2010).

${ }^{321}$ Level of Classification Redacted. Central Intelligence Agency. Director of Intelligence. Soviet-Iranian Relations After Khomeini. June 23, 1989 http://www.foia.cia.gov/docs/DOC 0000602666/DOC 0000602666.pdf (Accessed April 18, 2011).

${ }^{322}$ Level of Classification Redacted. Central Intelligence Agency. Director of Intelligence. Soviet-Iranian Relations After Khomeini. June 23, 1989 http://www.foia.cia.gov/docs/DOC_0000602666/DOC_0000602666.pdf
} 


\section{Conclusion}

While the Iranians have consistently ruled out the notion that their nuclear re-birth following the 1979 Revolution had nothing to do whatsoever with the Iran-Iraq war, there appeared evidence in the years following the end of the war that this was hardly the case. Within this context, it is customary for the mainstream accounts of Tehran's decision to accept the 1988 UNSC ceasefire resolution 598 to point mainly to the widespread war weariness, lack of breakthrough on the frontlines, recruitment challenges, fear of U.S. intervention, and Saddam's use of chemical weapons.

In 2006, however, former President Rafsanjani released a confidential memorandum by Ayatollah Khomeini addressed to the Iranian officials that set the stage for an alternative narrative. In the July 1988 memorandum, the Iranian Supreme Leader conveys the contents of correspondence between him and IRGC commander-in-chief Mohsen Rezaei a few weeks earlier where Rezaei insinuated an effective offensive could only be launched against Baghdad if Tehran possessed sophisticated weaponry including nuclear weapons. ${ }^{323}$ This was the first time and the earliest documented instance where an exhortation to militarily utilize a nuclear capability came from the nation's top military brass.

As much as Western media lavished attention on the released memorandum as indicating Iran's nuclear weapons predilection, however, the apathetic response it drew from Khomeini at the time demonstrates the marginal role the IRGC played in Tehran's nuclear policy under Khomeini. The letter by Khomeini also demonstrates that Saddam

\footnotetext{
(Accessed April 18, 2011).

${ }^{323}$ For Ayatollah Khomeini's memorandum, see http://mfarhangi.iut.ac.ir/edare/pages/page610.html (Accessed August 25, 2010).
} 
Hussein's use of chemical warfare during the Iran-Iraq war seems to have contributed to Iran's decision to speed up the campaign to salvage the remnants of the Shah's nuclear program. Furthermore, as Tehran was warily eying the resuscitation of Saddam's nuclear program following the destruction of the Osirak reactor, a determination was taking deep roots in Tehran not to concede an erratic Ba'ath regime any nuclear edge.

This document, additionally, demonstrates that the mid-1980s were perhaps the most crucial and formative years in the overall trajectory of the Islamic Republic's nuclear socialization. Additionally, the war-born technological and equipment procurement activities associated with the INP in this period had an enduring impact on the international community's attitude toward the trustworthiness of Iran's international contractual commitments.

This enduring impact was in no small part due to the fact that Iran never tried in the subsequent years to justify and recant the mid-1980s as an aberration era when it had to take a set of temporary emergency measures as a sovereign state in the face of overwhelming existential security challenges. As former IAEA Director General Mohamed Elbaradaei points out in his memoires, Tehran's adamant reluctance to admit to some level of under-the-radar activity in its nuclear behavior during the $1980 \mathrm{~s}$ significantly detracted from the credibility of its subsequent non-proliferation credentials and undercut the international community's willingness to give Tehran the benefit of the doubt, look sympathetically on the era, and provide Iran with a tabula rasa. ${ }^{324}$

Towards the late 1980s and as the Iran-Iraq war seemed to be stalemating, farfetched and fantasy-laced analyses and news articles were especially on the rise with

\footnotetext{
${ }^{324}$ Mohamed Elbaradaei, The Age of Deception: Nuclear Diplomacy in Treacherous Times (New York, NY: Metropolitan Books, 2011).
} 
regards to Iran's nuclear program. In what seemed to be no more than hunch- driven sensational journalism, for example, The Washington Post ran a piece authored by David Segal in April 1987 titled, “Atomic Ayatollahs: Just What the Mideast Needs-An Iranian Bomb." The article, after drawing much attention inside the beltway for three weeks, turned out to be almost completely based on "misquoted, misrepresented, and fabricated" information the author claimed to have obtained from an interview with Fereydoun Fesharaki, a prominent economist who left Iran after the 1979 revolution.

In what Segal called “a chilling glimpse of Iran's desire to acquire nuclear weapons," he related a meeting between Khomeini's confidant Ayatollah Mohammed Beheshti and Fesharaki in May 1979 during which the Ayatollah pleaded Fesharaki to build the atomic bomb for the Islamic Republic since "our civilization is in danger and we have to do it." ${ }^{325}$ Fesharaki wrote a chastising letter to the Post a few weeks later essentially debunking all the claims attributed to him in the piece. "Ayatollah Beheshti did not tell me it is my duty to build a bomb," Fesharaki wrote, adding, "As an economist (not a scientist, as Mr. Segal calls me), I am hardly capable of building a nuclear bomb." ${ }^{326}$ Segal's piece was only a foretaste of what was to come in the decades ahead as the credibility and reputational cost of getting Iran wrong kept hitting all-time lows year after year.

On a balanced reading, one notices that a sense of fatalism about Iran's predilection for proliferation crept into the U.S. foreign policy establishment since the mid 1980s. In other words, in this period, the United States came to internalize

\footnotetext{
${ }^{325}$ David Segal, Atomic Ayatollahs: Just What the Mideast Needs-An Iranian Bomb. The Washington Post, April 12, 1987.

${ }^{326}$ The Washington Post, May 2, 1987.
} 
proliferation as part of, as it were, the DNA of the Islamic Republic of Iran. The documents declassified so far don't shed a definitive diagnostic light on the inner workings of how this paradigm came about. However, the consensus view in Tehran on this has consistently been one of regime change. In other words, as far as Tehran was concerned, the United States instrumentally and opportunistically designated an innocuous civilian nuclear program as a proliferation threat in order to create an international atmosphere of contingency toward the Islamic Republic ultimately aimed at toppling the clerical regime. An analytical assessment of the securitization of the INP, however, reveals an infinitely more complicated trajectory.

On a more analytical reading, a host of political, economic, ideological, and military ingredients crept into the securitization process of the INP following the Islamic Revolution. On the economic front, the resuscitation of a previously renounced and denounced profligate program went right in the face of prevailing energy trends and raised proliferations concerns. From this perspective, the general sense in the mid 1980s, in diametrical contrast to the mid 1970s, was that the "peak oil" argument was far from an article of faith it was made out to be in the previous decade. As a matter of fact, the contrast in perception from the oil crunch of the mid 1970s to the 1980s oil glut couldn't be starker. This development coupled with a sharp drop on the demand side in the global energy market tremendously decreased the economic attractiveness of capital-intensive and time-consuming nuclear power plants. The new situation was so dire that in the early 1980 's, in the words of a U.S. intelligence memorandum, "the market in developing 
countries for nuclear power reactors virtually collapsed."${ }^{1327}$ Under these transformed circumstances, only magnified by the woeful status of Iran's coffers, a defiant push for nuclear energy could hardly make for a solid economic argument.

On the ideology front, the Islamic Republic never quite developed a consistent and cogent argument for the change of heart from the early days of the revolution when the Shah's nuclear program was impugned as a satanic undertaking. This lack of explanation was consequential in the lukewarm reception of Ayatollah Khamenei's 2007 Fatwa (religious degree) on the Islamic non-sanctionability of a range of nuclear options including the development, acquisition, stockpiling, threats to use, or actual use of nuclear weapons from a Shi'ite perspective.

On the military front, as earlier argued, the Islamic Republic's war-born nuclear awakening made a de-securitized narrative by Tehran hardly convincing while giving credence to proliferation intentions. Comparatively analyzed, if under the Shah the received rationale for why Iran might be incubating a nuclear weapons agenda was contextualized within the framework of the Monarch's insatiable thirst for state-of-the-art conventional weapons, in the Islamic Republic era, Tehran's alleged predilection for proliferation received a reverse mode of reasoning. Under the Shah, it was feared that the zestful conventional procurement could be naturally extended to the nuclear realm. In the Islamic Republic era, by contrast, it was either explicitly or implicationally argued that the ordeal of having been on the receiving end of Saddam's WMD strikes combined with Tehran's strategically disadvantaged position to procure conventional arms were factors

\footnotetext{
${ }^{327}$ Secret. National Intelligence Council Memorandum. The Dynamics of Nuclear Proliferation: Balance of Incentives and Constraints. September 1985. www.foia.cia.gov/docs/DOC_0000453458/DOC_0000453458.pdf (Accessed July 14, 2011).
} 
compelling enough for a lonely Islamic Republic to aspire to acquire at least some "threshold" nuclear capability for deterrence purposes. ${ }^{328}$

On the political front, the Islamic Republic's idealistic approach to the NPT didn't help decelerate the securitization of its nuclear behavior either. On this score, one has to bear in mind an important development that distinguishes the post-revolution Iran from the Shah's on the all-important question of the nature of the NPT. Under the Shah especially since the mid 1970s Tehran tended to view the main function of the NPT in terms of maintaining a non-nuclear status quo in Iran's strategic environment. Viewed from this perspective, the primary bargain of the treaty was one that was not even explicitly verbalized in the treaty, one that was only derivatively, circumstantially, and retrospectively visible. This was part of the reason why in the Shah's era one notices only minimum public critique of the nature of the bargain between the nuclear haves and havenots and the former's unfulfilled commitments under article VI to de-proliferate.

By contrast, in the post-1979 era Iran came to internalize and interpret the nature and purpose of the NPT quite differently. This time around, viewed from Tehran, the defining feature of the NPT's core bargain was article VI where the NNWS' abstention should have been commensurately reciprocated by a verifiable denuclearization in the NWS camp represented by the U.S. and the USSR. For instance, on February 19, 1995 Iran's UN Ambassador Kamal Kharrazi threatened Tehran would oppose an indefinite extension of the treaty unless a revision was made "in the accord binding signatories to a deadline for the destruction of nuclear weapons. ${ }^{, 329}$ Of course, over the years, especially

\footnotetext{
${ }^{328}$ Mohiaddin Messbahi, "Free and Confined: Iran and the International System," Iranian Review of Foreign Affairs 2, no. 5 (Spring 2011): 29-34.

${ }^{329}$ The New York Times, February 19, 1995.
} 
since the early 2000s and as Iran's nuclear capabilities were advancing and its future nuclear horizons were widening, Iran shifted the thrust of its critique of the NPT back to article IV of the treaty.

To pause a bit longer on this point an argument can be made that the defining feature of the Shah's conceptualization of the NPT was that it tied in Iran's contractual obligations under the treaty with the country's broader strategic security environment thereby making his non-proliferation pronouncements credible and externally verifiable from a realist International Relations perspective. The Islamic Republic, on the other hand, through decoupling its interpretation of the core bargain of the NPT from its security context, made a realist and non-normative reading of its nonproliferation claims extremely problematic and allowed a mercurial and Janus-faced aura to surround Tehran's entire nuclear posture.

Finally, in analyzing Tehran's nuclear behavior and the United States' response to it, parsing out a 1985 National Intelligence Council Memorandum's diagnosis is illuminating. This polemic document essentially argued that subjecting the policymaking environment on the proliferation issues to "the normal pull and tug of domestic politics" acts as a retarding if not permanently revising force on the "incentive structure" of proliferation. However, the United States almost never pursued this advice in the case of the Islamic Republic.

As a matter of fact, a case can be made that by inflating the military threat emanating from Iran's nuclear program in the late 1980s, Washington inadvertently helped privatize Tehran's nuclear decision-making away from the public and normal political arena into the more esoteric national security zone. This policy was in direct 
conflict with the report's most crucial assessment that:

"Over the next five years or so, there is a good chance that today's relatively favorable nonproliferation regime will not be seriously endangered. The principal factor leading to this conclusion is that only arguments of national security, particularly if they involve serious fears about potential national annihilation, are likely to carry enough weight with decision makers to override the negative reactions they might anticipate from supplier countries, neighbors, the international community, and from domestic critics of decisions to develop nuclear weapons. Few, if any, countries with developing nuclear capabilities seem likely to perceive so ominous a threat to their survival during this period."

Furthermore, the memorandum, rather realistically, predicted that the physical impediments and technological challenges in the way of proliferation would, over the long term, lose their effectiveness compared to normative counter-proliferation mechanisms that gain ideational traction and sedimentation over time. On this point, the document concluded, "if the industrial capabilities for developing an advanced nuclear infrastructure continue to spread, as seems virtually inevitable, the United States and other supplier countries may need to focus more on attempting to boost anti-weapon motivations in Third World countries than on technological denial, seeking to take advantage of doubts that already exist about the potential regional security and domestic political costs of making pro-weapon decisions. The challenge here is to find ways to enhance those concerns without causing a nationalistic backlash against perceived foreign interference in sensitive domestic matters." 330

\footnotetext{
${ }^{330}$ Secret. National Intelligence Council Memorandum. The Dynamics of Nuclear Proliferation: Balance of Incentives and Constraints. September 1985.
} 
Based on such a judgment, the memorandum warned the counter-proliferation community against making simplistic causal analyses that made a unidirectional link between technological capability and proliferation. The memorandum cited this faulty reasoning as a major cause why Washington's worst proliferation fears in the 1960s never transpired.

The memorandum faulted those "earlier projections about the probable rate of proliferation" with having "too narrow a perception of the process by which the spread of a nuclear explosive capability comes about." Due to this pathology, the report observed, "those predictions tended to be driven by straight line projections of such matters as how soon a country could have the ability to produce sufficient fissile material for an explosion, given its recent pace of technological acquisition." The end result of this mode of analysis, the document argued, was a kind of technological determinism "implying that if a country acquired more and more of the technical ingredients that go into making a nuclear device, the decision to consummate that option would ... eventually be made."

Drawing attention to the multifaceted nature of nuclear decision-making and warning against reducing it to its technical ingredients, the report explained how in parallel with "accretions" in technological capabilities, the decision-making process becomes more multidimensional and multisectoral since it has to take into account a whole slew of international and domestic economic, political, environmental, and societal considerations. ${ }^{331}$ As Washington's inflated threat designation of the INP demonstrated in

\footnotetext{
${ }^{331}$ Secret. National Intelligence Council Memorandum. The Dynamics of Nuclear Proliferation: Balance of Incentives and Constraints. September 1985. www.foia.cia.gov/docs/DOC_0000453458/DOC_0000453458.pdf (Accessed October 6, 2011).
} 
the mid to late $1980 \mathrm{~s}$, almost none of these sentiments found their way into the paradigmatic framework within which Tehran's nuclear behavior was construed.

Another major development following the Iranian Revolution of 1979 was an implicit transformation in the United States' security culture of what constituted proliferation. Although this change was acknowledged in a 1985 memorandum where it tracked how various NIEs since the 1960s progressively pushed back the definition of proliferation from "weapon capability" to "primitive nuclear-explosive capability" to "sensitive nuclear materials and facilities that might contribute to an explosive (or weapons) capability," ${ }^{332}$ its impact on the Islamic Republic was tremendously more visible.

It was based on such a new threshold that a 1985 intelligence report placed Iran, along with Iraq, Libya, and Egypt, as a country of "proliferation concern" who "have shown interest in developing the kinds of capabilities that, if they succeed, might eventually bring them to the technological level where they could create an explosive device. But events and other governments have conspired in the last several years to place such major obstacles in their paths that there is virtually no chance any of them could reach that level in the next 10 years. ${ }^{, 333}$ As president George Bush famously declared in 2007, applied to Iran, simply "having the knowledge necessary to make a nuclear weapon" essentially amounted to a proliferation scenario to be averted at all cost.

\footnotetext{
${ }^{332}$ Secret. National Intelligence Council Memorandum. The Dynamics of Nuclear Proliferation: Balance of Incentives and Constraints. September 1985. www.foia.cia.gov/docs/DOC 0000453458/DOC 0000453458.pdf (Accessed October 6, 2011).

${ }^{333}$ Secret. National Intelligence Council Memorandum. The Dynamics of Nuclear Proliferation: Balance of Incentives and Constraints. September 1985. www.foia.cia.gov/docs/DOC_0000453458/DOC_0000453458.pdf (Accessed October 6, 2011).
} 


\section{CHAPTER FIVE}

\section{NUCLEAR EXPEDIENCY (1988-1997)}

\section{Introduction}

The end of the eight year war with Iraq in late 1988, Ayatollah Khomeini's death in 1989 and the ascendency of a technocrat Rafsanjani to presidency removed a host of ideological, material, and bureaucratic constraints that had reigned in a full and systematic resuscitation of Iran's nuclear past. As opposed to what seems to have been a clandestine effort to contrive a "short-cut" route to militarily relevant nuclear capability during the mid to the late $1980 \mathrm{~s}$ - partly in response to Saddam's run for the bomb-Iran's nuclear strategy in the 1990 s was mainly characterized by a systematic effort to build a full-spectrum indigenous nuclear infrastructure that would communicate a deterring nuclear breakout capacity to would-be aggressors by putting Iran on the threshold.

The approach, commonly known as the "Japan option" in the non-proliferation circles, was essentially aimed at rekindling the Shah's strategy whose ideal goal was to equip Tehran with all the hardware and software ingredients necessary to build a deliverable nuclear device stopping just short of a political decision at the top. Tehran's thinking was that, in absence of a clear and present security threat, such a capability would enable it to reap the deterrent dividends of nukes "on the cheap" without having to pay the exorbitant economic, normative, and security costs associated with stockpiling them in a hostile environment.

Discrete elements of Iran's post-revolution nuclear thinking-- heavily influenced by what Tehran perceived was a conspiracy of silence by the international community in 
the face of Iraq's use of WMD during the 1980-1988 war-- began to cohere into a systematic conceptual and operational framework under the presidency of Ali Akbar Hashemi Rafsanjani. The technocrat cleric, who later showed a thinly disguised partiality to assume the mantle of the "father" of the Islamic Republic's nuclear program, was arguably the most instrumental figure in shaping Iran's nuclear strategy and in elevating it to the top of the country's national priorities in the post war period.

Iran's nuclear program in this period was simultaneously the beneficiary and a victim of the tumultuous early 1990s that saw the implosion of the USSR and the end of the Cold War. The INP got a boost, especially in terms of enhanced capability to secure components, following a decision by the Bush administration to lift US sanctions on the sale of high-tech equipment to Eastern Europe. The easing of control mechanisms on the high-tech sector was especially important for Tehran by giving it window of opportunity to secure the so-called dual-use parts and components from the cash-strapped USSR orbit countries.

The collapse of the Soviet Union, in the same time, brought about a macrosecuritizational transformation in the international system depriving Iran of much vital maneuverability and structurally de-securitizing pressures that bipolarity had conferred exercised on the INP. In other words, the punishment and rewards structure of the international system had now changed in such a fundamental way that Washington could aggressively hyper-securitize and antagonize the Iranian regime without worrying about its balance of power implications. ${ }^{334}$

\footnotetext{
${ }^{334}$ Mohiaddin Messbahi, "Iran and Central Asia: Paradigm and Policy," Central Asian Survey 23, no. 2 (2004): 109-139.
} 
Within this new context, following the collapse of the Soviet Union and Operation Desert Storm, the notion of "ambitious" power, in some ways reminiscent of the Shah era, began finding applicability to the Islamic Republic in Western policy circles. A new conventional wisdom was shaping up in Washington in the early 1990s that claimed, with the Soviet threat to the north eliminated and the mortal Baath enemy to the west emasculated, the Revolutionary regime was presented with an unprecedentedly hospitable strategic environment to throw its weight around in its periphery. Acquiring a nuclear capability, the argument went, would be an indispensible and organic component in Tehran's strategic toolbox to fulfill its ambitions.

It is also extremely important to view the elevation of the INP as a top security priority for the United States within the context of Washington's experience with Saddam's clandestine nuclear program whose proximity to a weaponizable capability virtually caught the White House off guard. Following the dismantlement of Baghdad's nuclear program after the 1991 Persian Gulf War, the conventional wisdom in Washington was that considering Iranian intelligence elements' penetrating capacity into Iraq's nuclear program - demonstrated by its intelligence sharing with the Israelis before the Osirak strike-Tehran should also have tried to match, if not outstrip, it archenemy's nuclear potential.

\section{The Soviet Collapse and the Cottage Industry of Securitizing the INP}

The unpredicted collapse of the Soviet Union particularly caught the U.S. counter-proliferation community off guard. The hard-currency-strapped nuclear remnants of the former empire, in the judgment of the U.S. intelligence community, generated a nuclear black-market where countries like Iran could tap to secure their technology, 
fissile material, and manpower needs unfettered by vigilant government oversight. In 1992, the Bush administration was already alarmed at the deluge of sophisticated conventional armaments like T-72 tanks and Su-24 and MIG-29 aircraft and a host unconventional know-how and hardware finding their way from the Former Soviet Union (FSU) to Iran. In one U.S. official's words, the new development had not only accorded Iran "parity" with its archenemy Iraq but could lead to an Iranian "dominance" over the Persian Gulf region where a heavily sanctioned Iraq was simply too anemic to offer much of a balancing act to a reinvigorating Tehran. ${ }^{335}$

Within this broad context in mind, Washington came to view with increasing suspicion Iran's laser-focused efforts to complete the BNPP. Put simply, in the George H. W. Bush Administration's perspective, there was more to the Rafsanjani administration's pull-out-all-the-stops campaign to complete the Bushehr nuclear reactor than met the eye. Nothing but proliferation intentions could justify Tehran's "single-minded pursuit of nuclear power plants in a country deficient in the capital required to build such plants and rich in natural gas that [could] fire power plants cheaply.",336

Internalizing the unfolding situation in threat terms, in 1992 the United States passed the "Iran-Iraq Non-Proliferation Act" essentially making it the official policy of the United States to "urgently" enlist the support of "other nations to oppose any transfer to Iran or Iraq of any goods or technology, including dual-use goods or technology, wherever that transfer could materially contribute to either country's acquiring chemical, biological, nuclear, or destabilizing numbers and types of advanced conventional

\footnotetext{
${ }^{335}$ Jack Nelson, Arms Buildup Making Iran Top Gulf Power, The Los Angeles Times, January 7, 1992.

${ }^{336}$ Patrick Clawson, "Ambitious Iran, Troubled Neighbors," Foreign Affairs (Council on Foreign Relations) 72, no. 1 (1992): 124-142.
} 
weapons. ${ }^{\$ 337}$ This decision marked the beginning of the international securitization of the INP.

In the Bush administration's view, the opening of what amounted to a nuclear bazaar in the FSU coupled with the increasingly non-scrutinized availability of nuclear know-how - in no small part thanks to the exodus of the FSU's nuclear scientists-had essentially given rise to an era of "nuclear ubiquity" where curbing a determined and well-off aspirant's foray into the bomb was next to impossible. In a January 1992 testimony before Congress, CIA Director Robert M. Gates put Iran exactly in this category alleging Tehran had "publicly" hinted at its interest to "have nuclear weapons. $" 338$

Although disputed by the U.S. military analysts, Gates' January testimony in Congress on the galloping pace of the INP made such an alarming impression that 17 ranking senators from both sides of the isle sent an "unusual classified letter" to Secretary of State James Baker inquiring about China's proliferation-related assistance to Tehran. In the view of Congress, any concrete move by the administration to lift sanctions on the transfer of U.S. nuclear technology to China should have been conditioned on securing Beijing's unqualified commitment to the Missile Technology Control Regime (MTCR)

\footnotetext{
${ }^{337}$ Iran-Iraq Arms Non-Proliferation Act of 1992 http://www.state.gov/t/isn/c15237.htm (Accessed May 12, 2011).

The term 'advanced conventional weapons' as defined in the act included-(A) such long-range precision-guided munitions, fuel air explosives, cruise missiles, low observability aircraft, other radar evading aircraft, advanced military aircraft, military satellites, electromagnetic weapons, and laser weapons as the President determines destabilize the military balance or enhance offensive capabilities in destabilizing ways;

(B) such advanced command, control, and communications systems, electronic warfare systems, or intelligence collection systems as the President determines destabilize the military balance or enhance offensive capabilities in destabilizing ways; and

(C) such other items or systems as the President may, by regulation, determine necessary for purposes of this title.

${ }^{338}$ David Hoffman, Iran's Rebuilding Seen as Challenge to West, The Washington Post, February 2, 1992.
} 
established in 1987 by the United States and its western allies to forestall the dissemination of WMD delivery systems. Especially raising the Senate's ire was the prospect of the transfer of the newly commissioned M-9 and M-11 ballistic missiles to countries like Iran. ${ }^{339}$

Under such uncertain and highly dynamic circumstances, in 1992 Washington's concerns that Iran would beat it to the draw in the FSU reached such a feverish pitch that the Bush administration dropped securing ironclad commitments on human rights, the START treaty, and market-based economy as part of the United States' preconditions to establish full-fledged diplomatic ties with the newborn FSU countries in Central Asian and Caucuses. This was a central component of the Administration's efforts to keep tabs on Iran's activities in Central Asia and the Caucuses, a region "up for grabs" by Tehran in Washington's judgment. As part of this effort, in February 1992, Secretary of State James Baker visited the region to speed up the establishment of U.S. embassies in Azerbaijan, Uzbekistan, Turkmenistan, Tajikistan and Kazakhstan to neutralize Iran's expanding political sway. ${ }^{340}$

As public and private expressions of concern by the U.S. over the INP were intensifying, an IAEA delegation conducted an inspection of Iran's nuclear facilities at Tehran's invitation in early February 1992. The nuclear watchdog's findings couldn't be more frustrating for Washington's securitization agenda. In some disarmingly categorical remarks, Dr. John Jennekens, the delegation's spokesperson reported, "there does not seem to be a shred of evidence on the allegations that were made in the media." Praising

\footnotetext{
33917 Senators Write Baker on China's Arms Sales Policy, The Los Angeles Times, February 9, 1992.

${ }^{340}$ U.S. to Counter Iran in Central Asia, The New York Times, February 6, 1992.
} 
the "ready access" Tehran had granted to six nuclear facilities and staff members, he added, "Nothing we have seen proves that there is any activity here against the peaceful principles of nuclear policy." 341

The IAEA report on two sites of concern was especially compelling in dispelling much speculation over Tehran's nuclear intentions. One was the site of cauldron equipment in Isfahan that Washington suspected of having enrichment applications. Confirming Tehran's claims that it was exclusively used to "produce stable isotopes of zinc for pharmaceutical purposes," the IAEA concluded, "There are absolutely no facilities for handling or coping with radioactive material in the building housing the cauldron.” The other suspicious site in Moallem Kalayeh in Northern Iran, claimed by the Iraq based Mojahedin-e-Khalq Organization (MKO) to be a secret nuclear facility, was declared by the Agency a "motel-sized" recreational retreat for nuclear scientists. The IAEA team came so close to issuing the INP a clean bill of health that one of its French experts "deplored" the fact that Iran was "under a de facto embargo on nuclear equipment." ${ }^{342}$

Following the IAEA report, the Bush administration backpedaled on its highdensity threat forecasts, conceding there was "no smoking gun in the way of weapons intent." 343 This reassuring report (and the follow-up report presented by IAEA Director General Hans Blix in 1993), however, didn't manage to put the issue to rest as the nuclear watchdog organization was accused of credulity in its inspections by the United States

\footnotetext{
${ }^{341}$ Atom Agency Finds No Threat at Iran's Sites, The New York Times. February 13, 1992.

${ }^{342}$ The Christian Science Monitor, February 18, 1993: 7.

${ }^{343}$ Atomic Team Reports on Iran Probe; No Weapons Research Found by Inspectors, The Washington Post, February 15, 1992.
} 
since it couldn't unearth the more sophisticated clandestine aspects of Iran's nuclear enterprise.

The dust on the issue had barely settled down when in May 1992 a European newspaper, quoting unidentified intelligence sources, made the headlines claiming Iran had spirited in two nuclear warheads from the Atomic Research Institute of Kazakhstan in cahoots with president Nursultan Nazarbayev. The United States spurned the credibility of the intelligence citing lack of verifiability. ${ }^{344}$

Shortly afterward, the INP hit the securitization zone again in November 1992 when Vice President of Iran for Legal and Parliamentary Affairs Ata'ollah Mohajerani made international news headlines by obliquely suggesting that Islamic countries should strive to match Israel's nuclear capability. ${ }^{345}$ Although the crude statements were later repudiated and retracted as personal statements of desire by some junior politician, some policy circles in Washington and Tel Aviv were quick to interpret them as indicative of the Islamic Republic's endeavor to develop nuclear weapons.

\section{Clinton and "Dual Containment"}

In 1993 and with the election of Bill Clinton as the $42^{\text {nd }}$ President of the United States, Iran's nuclear program plunged deeper into the securitization zone. Unhappy with the Bush Administration's purportedly laser-focused attention on Iraq and its implications for tilting the fragile regional balance in Iran's favor, the Clinton administration set out to rectify the perceived disequilibrium. Taking a swipe at its predecessor's Iran policy, a Clinton administration official said the Bush people "had the notion that goodwill begets

\footnotetext{
${ }^{344}$ Iran-Kazakhstan Nuclear Deal Reported. 1992. Los Angeles Times; May 01, 1992. http://search.proquest.com/docview/281674125?accountid=10901 (accessed August 19, 2010).

${ }^{345}$ The Washington Post, November 17, 1992: A 30.
} 
goodwill," but "when we came into office, all we saw was an outlaw regime.... We cannot engage in the process of improving relations with an outlaw state unless we see change across the board." He concluded, "Iran, Iraq, Cuba, Libya and North Korea are unable to interact with the international system in a constructive, positive way, so they build links to each other. What they have in common is the effort to acquire weapons of mass destruction." ${ }^{346}$

"Dual containment" was the policy response reflecting the new thinking in the new White House. Incubated in the early 1990s by Martin Indyk at the Washington Institute for Near East Policy (WINEP), the policy sought to subject the Iranian regime to a sweeping arms sanctions regime comparable to those imposed on Baghdad so the status quo could be restored at least over the short and medium term.

Secretary of State Warren Christopher, Clinton's most veteran diplomat on Iran and a leftover from the Carter Administration, was the public face of the new policy strategy. As the chief negotiator with the Iranians during the hostage crisis, Christopher's vision of Tehran was deeply scarred by those crisis-ridden 444 days. Frequently referring to Iran as an "international outlaw," Christopher made the rounds of international capitals urging his counterparts to treat Iran "as the most worrisome" state bent on acquiring a nuclear capability. ${ }^{347}$

As the administration was scrambling to generate traction for dual containment, another classified letter sent to the Secretary of State by Senators Claiborne Pell and Jesse Helms on China's under-the-counter arms dealings with Tehran injected a renewed sense

\footnotetext{
${ }^{346}$ Quoted in The Washington Post, February 27, 1994.

${ }^{347}$ The Washington Post, June 10, 1993.
} 
of urgency to create consensus across all the branches of government and shift the heat from the headache in Baghdad to the real challenge in Iran. The dilemma emanating from Iran's nuclear defiance was even more worthy of acute attention, in the new conventional wisdom putting down roots in Washington, given the clerical regime's intimate ties to the terrorist organizations in the Middle East. ${ }^{348}$

Incrementally, the Clinton's Administration's efforts to isolate Tehran assumed such broad dimensions that some policy experts speculated Tehran had, for all practical purposes, substituted Moscow as the "New Evil Empire" in Washington's eyes. An operational component to this new perception was the United States' strenuous efforts to restrict Iran's strategic options even in instances where Washington's interests were not concretely at stake. A vivid manifestation of this was the Clinton administration's policy to dissuade the FSU countries from piping their oil through the Iranian corridor. This obstructive attitude, as far as Tehran was concerned, constituted an example par excellence of a swaggering post Cold War White House whose hostility toward Tehran had grown gratuitous and incorrigible. Viewed in the same light in Tehran was the Clinton administration's approach in stonewalling and squelching financially distressed Iran's efforts to restructure its sovereign debt and secure additional international loans for post-war reconstruction projects.

In this atmosphere of enmity, "the bill of particulars" leveled against Iran continued to thicken further in the early 1990s with Tehran's obstructionist approach toward the two US-sponsored Arab-Israeli peace initiatives: the 1991 Madrid Conference and the 1993 Oslo Peace Accords. Tehran's miscalculation on this issue catapulted Israel

\footnotetext{
${ }^{348}$ The Washington Post, August 12, 1993.
} 
to the forefront of the INP's securitizing agents. More internationally, with the 1991 Persian Gulf War widely believed to have slammed the brakes on much of Baghdad's nuclear capability, the INP became more conspicuous on the West's counter-proliferation radar. Reflecting the altered circumstances, Israeli Prime Minister Yitzhak Rabin relayed to the Knesset in a January 1993 speech Tel Aviv's estimate that Iran already possessed "the appropriate manpower and resources to acquire nuclear weapons within the next 10 years...unless there is an appropriate international effort to prevent Iran from achieving its ends." In justifying Israel's characteristically hysterical judgments on the INP, Rabin implied that Iran's acquisition of Scud-C missiles technology from North Korea left no doubts about Tehran's offensive intentions. ${ }^{349}$ A heightened sense of concern over the INP gained even more traction as David Kay, the former UN Chief Weapons Inspector drew a parallel between the INP and the initial stages of Saddam's program. ${ }^{350}$

The synergetic impact of these factors resulted in a tone-deaf attitude in Washington toward the conciliatory gestures of the pragmatic President Akbar Hashemi Rafsanjani and a sense of vindication among the old-guard hardliners' in Tehran who argued Washington's animosity toward the Islamic Republic was categorical and not issue oriented. Based on this latter argument, advocated most prominently by Supreme Leader Ayatollah Seyyed Ali Khamenei, the Iranian nuclear issue, just like other allegations, was simply a tool of convenience opportunistically utilized by the United States to camouflage and facilitate a more fundamental regime-change policy.

\footnotetext{
${ }^{349}$ The Jerusalem Post, January 21, 1993.

${ }^{350}$ The Times, March 9, 1993.
} 
Bestowing even more credibility on the Iranian hardliners' argument was an institutionalizing posture in Washington's conservative policy circles that Iran's proliferation behavior had almost nothing to do with the political configuration of power in Tehran as long as the cardinal framework was one of Islamic Republic. As a matter of fact, some even went so far as to claim that the real threat emanated from the pragmatists like Rafsanjani posing as moderates who were "most keen to develop conventional and nuclear arsenal." 351

The policy of "actively" containing Tehran (masquerading as "dual containment" policy) was not without its vocal critics in Washington either. Viewing the Iran situation in light of the broader context of the United States' counter-proliferation experience with North Korea and Iraq, the critics were pressing the point that the policy of not directly dialoguing with the ill-disposed proliferators was as simplistic as it was unproductive. Gary Sick, the prominent Iran veteran in the National Security Council under the Ford and Carter administrations was among the most vocal critics of the Clinton's policy.

From Sick's vantage point, the policy ran the risk of unnecessarily escalating matters with an otherwise approachable and impressionable Tehran to a crisis level. These were not the only pathologies associated with dual containment though. The policy “is openly disregarded and privately mocked even by many of our friends in the region, as I learned in a meeting this summer with representatives of Persian Gulf states," observed Gary Sick adding, "Contrary to prevailing pop analysis and wishful thinking,

\footnotetext{
${ }^{351}$ James Phillips, "The Saddamization of Iran," Hoover Institute Policy Review; No. 69; (Summer 1994).
} 
our jawboning and obstruction of international development credits for Iran will neither transform nor bring down the Islamic revolutionary regime."352

Critics were also skeptical of "singling out" Iran based on a litany of grievances where others in the Middle East could hardly produce a more laudable report card. Labeling the administration's obsessive fixation on Iran a "policy trap," Edward Shirley tried to contextualize Tehran's proliferation behavior against a more strategic backdrop. Echoing hardcore realist sentiments, he wrote: "Iran has probably sought to construct or purchase weapons of mass destruction. But who would not in the Middle East? Iran was gassed into surrender in the first Persian Gulf war; Pakistan, Iran's proselytizing Sunni neighbor to the southeast, probably has the Bomb; Saudi Arabia, its most ardent and reviled religious rival, has longer-range missiles; Syria is engaging in a major military buildup, courtesy of Saudi-American largesse during the second Persian Gulf war; Iraq and its Scuds are still just across the border; and Israel has both missiles and nuclear weapons. Iran, having been vanquished by a technologically superior Iraq, knows very well the proliferation nightmare that can ensue when the arms possessed are insufficient to deter... If the theory of deterrence works in the Muslim world, the mullahs will be as subject to its roles as were hardcore Soviet communists. As long as Washington or Jerusalem maintains a serious counter-threat, the Iranian nuclear menace remains effectively checked by the West. ${ }^{, 353}$ Shirley's harangue was a frustrated reaction to the fact that the theory of nuclear deterrence- an article of faith for the majority of the Cold War baptized generation of the U.S. foreign policy establishment- had magically lost all its applicability to Iran. One could argue that the main reason for this otherwise eerier

${ }^{352}$ The Los Angeles Times, November 17, 1994: 7.

${ }^{353}$ Edward G. Shirley, "Iran Policy Trap," Foreign Policy, no. 96 (Fall 1994). 
lack of appetite for deterrence was that, it in the eye of Washington, it would complicate the securitizing of the INP by undermining the end-of-the-world paradigm within which Iran's nuclear program was marketed and internalized. Put more crudely, viewed from Washington, securitization trumped deterrence and anything else that interfered with its proper articulation.

In such an atmosphere where securitization reigned supreme, the international nuclear watchdog's vouching for Iran's compliance with its NPT commitments generated little ripple effect into the policymaking circles in Washington. In point of fact, the nonchalant fashion in which the IAEA reports on Iran's nuclear bona fides was being received in Washington marked the beginning of "politicization of intelligence" on the INP. For instance, although in 1994 intelligence evidence concluded that shrinking oil revenues had slowed down the INP and forced a discretionary debate in Tehran on the cost-benefit wisdom of pushing the nuclear program forward, its impact on the policy level was miniscule. ${ }^{354}$ As if completely oblivious to the IAEA reports, in March 1994 Anthony Lake wrote an influential article in Foreign Affairs where the National Security Advisor put Iran and Iraq in the category of "reactionary backlash" regimes bent on proliferation that needed to be confronted and neutralized. ${ }^{355}$

Running in parallel to the politicization of intelligence- perhaps one of its spin-off effects- was a logic-defying tendency in Washington to read proliferation into every aspect of Iran's nuclear program, no matter how far-fetched its weaponization implications. In this climate, it was hardly surprising that the conclusion of a preliminary

\footnotetext{
${ }^{354}$ The New York Times, July 5, 1994.

355 Anthony Lake, "Confronting Backlash States ," Foreign Affairs 2, no. 73 (March/April 1994).
} 
agreement in January 1993 with China to build two 330 MWe nuclear power stations and the signing of a contract with the Russian Federation in January 1995 to build a 915 MWe VVER-1000 pressurized water reactor (PWR) triggered a kneejerk hysterical reaction in Washington. This melodramatic response acquired more ironic proportions when some analysts pointed out that these reactors had no direct proliferation implications and were in fact comparable to the "light-water nuclear plants being offered cost-free to North Korea in return for its agreement to give up its graphite reactor technology. $" 356$

\section{INP's Russia Connection Sends Securitization to New Heights}

In 1995 an unprecedented surge, both in scope and depth, in the securitization of the Iranian nuclear program took place. The trigger came, by and large, from the formal conclusion of a January 1995 accord with Russia. Worth $\$ 800$ million, the agreement was Iran's first successful shot at completing the first unit of the BNPP within four years. Almost immediately following the agreement, however, came US Defense Secretary William J. Perry's comments over the apocalyptic implications of a nuclear Iran. ${ }^{357}$

The nuclear deal with Russia changed the dynamics of the Iranian nuclear program in the sense that whereas prior to 1995 U.S. threat designations of the INP were informed by speculation, analogy, intention-reading, and intelligence estimates, the conclusion of the 1995 deal provided a seemingly concrete platform to hammer home Washington's securitizing posture and generate international consensus around it.

\footnotetext{
${ }^{356}$ Gary Sick, "Iran: the adolescent revolution ," Journal of International Affairs 49, no. 1 (Summer 1995): 145-166.

${ }^{357}$ The Washington Post, January 9, 1995
} 
Additionally, it set the stage for the internationalization of a comprehensive sanctions regime heretofore unilaterally imposed by the United States.

Despite the Clinton Administrations' strenuous efforts to secure maximum international support for its sanction policy, however, America's North Atlantic allies only put up a pro forma and reluctant attitude toward the proposed sanctions regime. This reluctance, on the part of Europe and Japan, was based on an implied conviction that the U.S. allegations against Iran still suffered from physical fact deficiency. In other words, from the European and Japanese perspectives, the body of damning evidence produced by the U.S. intelligence community on the INP was long on speculation, inference, intention judging, future scenarios, circumstantial evidence and short on direct evidence like satellite photos and steel and concrete facts. For example, word got around that during the 1995 US-Russian summit meeting in Moscow, president Clinton failed to present Yeltsin with a "satellite photograph of an Iranian nuclear headquarters from which a nuclear weapons program might be directed. This was because, a New York Times article explained, no such center existed." ${ }^{.358}$ This situation, in the words of the Washington Post's investigative report, sensationally titled "The Atomic Ayatollahs," made Washington's sanctions touting argument vulnerable to the charge it was "overreacting because it remained obsessed with Iran's mullahs after 16 years of vitriol, hostage-taking and spilt blood. ${ }^{359}$

As touched upon before, introducing yet another kink to Washington's argument was the fact that while the replacement of Yongbyon's graphite moderated reactor with a

\footnotetext{
${ }^{358}$ Andrew I Killgore, "Israeli-Inspired U.S. Pressure May Backfire in Iran," The Washington Report on Middle East Affairs 3, no. XIV (September 1995).

${ }^{359}$ The Washington Post, May 7, 1995.
} 
light-water version was being advocated as a counter-proliferation success in North Korea, Tehran's projected acquisition of the same kind of reactor from Russia was deemed a proliferation event. The internal inconsistency in exactly what constituted proliferation coupled with a lack of smoking gun substantially detracted from the credibility of Washington's slam-dunk judgments on the INP, making some allies question the authenticity of the United States' panic button when it came to Tehran. As if the atmosphere was not already foggy enough, the IAEA added to the confusion by repeatedly certifying the INP's compliance with the NPT. This was much to the public irritation of the Clinton administration whose top officials insisted Iran was in breach of the spirit of the treaty by shrewdly abusing its loopholes. ${ }^{360}$

A side effect of this comprehensive securitizing move by Washington was the virtual foreclosing of nuclear diplomacy with Tehran so the INP could be buried deeper in the security zone. As a New York Times editorial pointed out in 1995, not only did this blanket securitizing policy ran the risk of "aggravating Iranian paranoia, and adding motivation to build the bomb," it also managed to "impede efforts to halt Iranian bombmaking by limiting diplomacy, and by trying to stop all other countries' commerce with Iran instead of focusing on trade in bomb-building technology."

Immediately following the threat drumbeat issuing from Washington and Tel Aviv, Tehran and Russia orchestrated de-securitizing moves of their own. As part of this effort, along with reissuing comments by Moscow reminding the West of its unimpeachable proliferation track record following the ratification of the NPT, Iran's

\footnotetext{
${ }^{360}$ The Christian Science Monitor, June 1, 1995.

${ }^{361}$ The New York Times, January 8, 1995.
} 
ambassador to the IAEA Mohammed Sadegh Ayatollahi announced Iran's pledge to return to Russia the irradiated (spent) fuel rods that could contain plutonium isotopes ( $\mathrm{Pu}-$ 239) suitable for weaponization. Not impressed with the arrangement, Warren Christopher minced no words letting the Russians know that the White House "will not ultimately be satisfied by anything other than the end of the nuclear cooperation program." The State Department's rationale for pursuing such a "purist" policy was concerns that the BNPP could become the gateway for the transfer of militarily applicable nuclear technology to a rogue state. ${ }^{362}$

In the meantime, the US Congress, skeptical of Clinton's "solicitous" attitude toward President Yeltsin, threatened to "cut off all aid to Russia" unless the Kremlin rectified what a Senator called its "inexplicably stupid moves." ${ }^{\text {363 }}$ A defiant Moscow shot back, calling the nuclear deal with Tehran "a high-stakes issue all around" and suggesting that Washington's status as a "strategic partner" had eroded. Moscow went even further accusing Washington of "double standards" by opposing the Iran deal on commercial, and not proliferation, grounds while offering the same type of reactors to Pyongyang. Russia's Atomic Energy Minister Viktor N. Mikhailov's retort to Congress's threat couldn’t be more bristling: “The [Russian] Atomic Energy Ministry has received \$215 million in U.S. aid to help Russia dismantle its own nuclear weapons but has lost $\$ 450$ million in potential sales of uranium to the American market because of U.S. antidumping restrictions. "364

\footnotetext{
${ }^{362}$ The New York Times, May 5, 1995.

${ }^{363}$ The New York Times, February 23, 1995.

${ }^{364}$ The New York Times, February 24, 1995.
} 
Almost caught in the Moscow-Congress crossfire and in an effort to meet halfway a consternated U.S. Congress's push for crushing pressure on Iran and to demonstrate to US allies and rivals the priority of putting maximum teeth into the sanctions regime, president Clinton issued an executive order in March 1995 barring all U.S. entities from supervising, financing, and managing Iran's petroleum projects. ${ }^{365}$ The measure was expanded and tightened further in June to include almost all trade with Tehran. The immediate effect was the killing of a pending \$1-billion deal between a Dutch subsidiary of Conoco Oil Company and Iran to develop the offshore Sirri oil field. Panoramically viewed, the cancellation of the Conoco deal was a watershed event that marked the total departure of Iran-US relations from the economic zone after the 1979 revolution. In other words, this development dispossessed Iran-US relations from its most powerful desecuritizing potentiality, i.e., U.S. commercial interests in Iran.

In this atmosphere and as the triangular Moscow-Tehran-Washington thicket was spiraling out of control, a New York Times editorial warned the White House and Congress against pushing the envelope lest Washington ended up with the worst of all worlds. "The most likely outcome of all this is that Iran will get the reactors, the United States and Russia will be estranged, the destruction of Moscow's nuclear arsenal will slow and efforts to curb the spread of nuclear arms will be set back," darkly warned the editorial. $^{366}$

Washington, however, kept clamorously pressing the line that Tehran was on a "crash program" to nuclearize. This time, the United States also pointed fingers at a "side

\footnotetext{
${ }^{365}$ Paul Richter; Robin Wright. Clinton Kills Pending Iran-Conoco Oil Deal Policy, The Los Angeles Times. March 15, 1995.

${ }^{366}$ Russia, Iran and the Bomb: [Editorial], The New York Times, February 26, 1995.
} 
agreement" Tehran had presumably signed with Russia's Atomic Energy Ministry to obtain gas centrifuges to indigenously enrich uranium. Whereas in Washington's judgment such a capability could only shortcut Tehran's route to obtaining weaponsgrade fissile material, Moscow expressed confidence that, with proper monitoring, Tehran would exclusively use the equipment to obtain the LEU necessary for the BNPP and other civilian power plants.

At this time, Tehran, having sensed the vulnerability of the United States' nonproliferation position in international forums, found the upcoming NPT review conference of 1995 (up for extension or expiration) a golden opportunity to diffuse its nuclear file. In an effort to bring into sharp relief the discriminatory fault line separating nuclear haves from have-nots, Tehran tapped into the numerical majority of the NAM countries. Already feeling the heat and the international trend U.S. sponsored sanctions were taking, the Iranian officials were making the rounds of NAM capitals soliciting a "vote against the NPT's extension unless the use of export controls against a country in compliance with the treaty is made illegal." Depicting itself as the "Article IV victim" of a loophole-riddled NPT and losing no opportunity to throw light on Washington's deafening and embarrassing silence on Israel's nuclear anomaly as the weakest link in the United States' counter-proliferation argument, Tehran, in the words of Jessica Mathews of the Council on Foreign Relations, "skillfully persuaded most of the non-aligned countries to turn its special case into a generic issue. ${ }^{367}$

Further raising the stakes on the 1995 NPT review conference, on February 19, 1995 Iran's UN Ambassador Kamal Kharrazi threatened Tehran would oppose an

\footnotetext{
${ }^{367}$ Nuclear Weapons: The Iran Question, Jessica Mathews, The Washington Post; January 22, 1995.
} 
indefinite extension of the treaty unless a revision was made "in the accord binding signatories to a deadline for the destruction of nuclear weapons." ${ }^{368}$ Notwithstanding its out-of-the-ballpark rhetoric before the review conference though, Iran's actual behavior at the venue was rather subdued. The most scathing comments at the venue came from Cyrus Nasseri, Iran's Permanent Representative to the UN Office at Geneva who accused the United States of having "violated the terms of the NPT" by depriving Iran of its "rights" to have access to nuclear technology on the basis of some unauthenticated speculation and circumstantial evidence. ${ }^{369}$

In the meantime, as the United States' sanctions regime on Iran had generated crisscrossing rifts between Washington and almost the rest of the world, in May 1995, Iran's Atomic Energy Organization chief Reza Amrollahi announced Tehran's plans to build 10 nuclear power plants over the next two decades to generate some $20 \%$ of the country's electricity needs. Amrollahi also disclosed that Tehran had already paid the "down payment" to the Chinese for construction of two 300-MWe pressurized-water reactors (PWR). This announcement, considering Beijing's perceived technological limitation to independently conduct turnkey nuclear projects, came as a surprise to the Americans and its European allies. ${ }^{370}$

While Washington was turning up pressure on Tehran at an accelerated rate, puzzled policy analysts were trying to come to analytical grips with the "exceptional" treatment Iran was receiving in Washington. The gamut of explanations ranged from the

\footnotetext{
${ }^{368}$ The New York Times; February 19, 1995.

${ }^{369}$ The Washington Post, May 6, 1995.

${ }^{370}$ The New York Times, May 14, 1995.
} 
influence of the Israel factor ${ }^{371}$ to the preparatory stages of taking kinetic action against Tehran. The New York Times' David Sanger tried explaining "the Iran exception" by tapping into the configuration of lobby groups shaping and shoving policy inside the beltway. "Perhaps the real reason that the Administration was able to act so strongly today is simple politics," he maintained, adding, "What Iran lacks in the United States, for understandable reasons, is any constituency in Congress. The Administration was under tremendous pressure from the business community last year to separate human rights from the issue of trade preferences for China. There is an active Vietnam business lobby, led by companies that realize that the country may be the last source of welleducated, well-disciplined and very inexpensive labor in Southeast Asia. But by and large, American companies are not clamoring for a chance to work in a country that still routinely calls the United States the 'great Satan." 372

In the meantime, Clinton's sanctions executive order came to hurt Iran's economic interests next door in the FSU sooner than Tehran anticipated; In April 1995, "bowing to U.S. pressure," the Republic of Azerbaijan divested Iran of its 5\% share in a consortium to develop the country's offshore oil deposits in the Caspian Sea. ${ }^{373}$ Also under mounting US pressure and agitation, Moscow bowed out of the tentative agreement to sell a gas centrifuge plant to Tehran. ${ }^{374}$ A mix of U.S. pressure and dwindling oil revenues also convinced Beijing to drop out of a contract to sell Iran a uranium

\footnotetext{
${ }^{371}$ David Hoffman, The Washington Post, March 13, 1993.

${ }^{372}$ David Sanger. The Iran Exception; U.S. Will Deal With Other Old Foes But Still Sees Teheran as an Outlaw. The New York Times, March 15, 1995.

${ }^{373}$ The Los Angeles Times, April 11, 1995.

${ }^{374}$ The Los Angeles Times, May 04, 1995.
} 
hexafluoride conversion plant it was planning to set up at the Esfahan Nuclear Technology Center (ENTEC). The purchase of the uranium conversion facility (UCF) would enable Tehran to convert the yellow cake into pure uranium gas (UF6) required for gaseous diffusion enrichment. In Washington, this was deemed a key initial step in Tehran's efforts to indigenously master the full fuel cycle. Whereas Iran claimed it needed the facility to manufacture fuel rods for its civilian nuclear reactors, the United States viewed it as part of a sophisticated scheme in Tehran to sneak its way into weapons-grade uranium. ${ }^{375}$

\section{Dual Containment and Its Critics}

As Indyk's prescription for countering Iran was coming under mounting pressure from multiple fronts in 1995, an increasingly hawkish Secretary of State was elevating the Iranian menace well beyond the dual containment policy. "Iran today is in a category all its own," Christopher said, adding, "No other regime employs terror more systematically as an instrument of national policy."376 Shortly following the remarks, the Administration, accused of being slow on the trigger by both the Israelis and the Congress in turning up the heat on Iran, expressed support for a \$ 20 million covert plan, led by House Speaker Newt Gingrich, to counter Tehran's reckless behavior and destabilize the clerical regime by supporting to its diehard opponents.

This development marked the entering of the INP to the covert military zone in the beginning of 1996. A few months after this revelation, came news that the president

\footnotetext{
${ }^{375}$ Smith, R. J. 1996. China may cancel proposed sale of nuclear facility to Iran. The Washington Post Nov 06, 1996. http://search.proquest.com/docview/307985081?accountid=10901 (accessed August 26, 2010).

${ }^{376}$ The Washington Post, May 8, 1995.
} 
had signed into law the Iran Libya Sanctions Act (ILSA) on August 5, 1996. The key provision of the act, first introduced by Senator Alfonse D'Amato of New York, required "the President to impose at least two out of a menu of six sanctions on foreign entities and persons that [made] an investment of more than \$20 million in one year in Iran's energy sector." ${ }^{377}$

As President Clinton was going hot and heavy against the INP, the critics of "dual containment run amuck" were growing increasingly vocal as well. Highly critical of the Administration's policy in burning all the bridges to Tehran, Richard Murphy, former Assistant Secretary of State for Near Eastern and South Asian Affairs took the rationality of these excessive measures to task. "The policy of 'dual containment,' that seductive phrase which quickly became part of the vocabulary of American Persian Gulf policy in 1993, has helped paralyze our thinking about Iran", he wrote, imploring the White House to step back and revisit its perspective on Tehran. Contrasting the United States' Iran policy with the Cold War era, Murphy maintained, "Containment has lost the meaning we once gave it when we talked for nearly half a century of containing the Soviets. Today we routinely dismiss the Iranian Islamic regime as a pariah state. But history and geography work against that mindset. Iran is a major state in the region and sooner or later will again make its weight felt." ${ }^{378}$

\footnotetext{
377 "The six sanctions were (1) denial of Export-Import Bank loans, credits, or credit guarantees for U.S. exports to the sanctioned entity; (2) denial of licenses for the U.S. export of military or militarily-useful technology to that entity; (3) denial of U.S. bank loans exceeding \$10 million in one year to the entity; (4) if the entity is a financial institution, a prohibition on its service as a primary dealer in U.S. government bonds; and/or a prohibition on its service as a repository for U.S. government funds (each counts as one sanction); (5) prohibition on U.S. government procurement from the entity; and (6) a restriction on imports from the entity, in accordance with the International Emergency Economic Powers Act." See Kenneth Katzman, The Iran-Libya Sanctions Act (ILSA), (CRS Report for Congress, 2006).

${ }^{378}$ It's Time to Rethink the US-Iran Relationship, Richard Murphy, The Christian Science Monitor, 18 July 1996: 18.
} 
Also prominent among the critics of Clinton's Iran policy was Zbigniew Brzezinski, Carter's National Security Advisor, whose change of heart on the clerical regime was most visible. The onetime advocate of a military coup as an antidote to the Iranian Revolution was now all about engaging Tehran. "I do not see any reason why we should be pursuing a policy of isolating Iran," he argued, reasoning, "because Iran, if we pursue hostility towards it, makes it more difficult to isolate Iraq." Pressing for the need to forge "a good strategic relationship with Iran in the longer run," Brzezinski argued such a development would ensure stability in the Middle East and Washington's access to the energy corridors of Central Asia. Similar sentiments were being echoed by Brent Scowcroft, the two-time National Security Adviser under Presidents Gerald Ford and George H. W. Bush.

These disparate voices for change finally coalesced in 1997 putting forward the most scathing critique of the administration's policy by a bipartisan group of three foreign policy gurus. In a Foreign Affairs article entitled "Differentiated Containment," Zbigniew Brzezinski, Brent Scowcroft, and Richard Murphy tore dual containment apart as more of an unsustainable "slogan than strategy" that was "far too blunt an instrument to serve American interests in the Middle East." Critical of Clinton's unilateral sanctions policy as "extraterritorial bullying," they called into question the "justification for the treatment" Washington was visiting on Tehran over its nuclear program. "Instead of simply punishing the country," they called for a policy of "pushing the controls and inspection provisions of the existing nuclear nonproliferation regime to their limits and continuing to make counter-proliferation efforts a top priority." ${ }^{, 379}$

\footnotetext{
${ }^{379}$ Zbigniew Brzezinski, Brent Scowcroft and Richard Murphy, "Differentiated containment," Foreign Affairs 3, no. 76 (May/June 1997): 20-30.
} 
Such a sea change in policy, however, would involve a drastic trimming down of the Iranian threat package Washington had grown accustomed to, one that included more nebulous elements like opposition to the Middle East peace process and human rights abuses. As the administration's INP policy was suffering from a threat deficit in absence of a smoking gun, such a radical re-articulation would enervate the securitization energy of Clinton's Iran policy and naturally fell on deaf ears.

In resonance with these domestic foreign policy heavyweights, key European allies France and Germany (with massive economic ties to Iran) wasted no time questioning the extraterritoriality of the seemingly disproportionate measures. The Clinton administration's decision to forge ahead with the sanctions track was, in the judgment of the Europeans, a suboptimal policy choice considering its sloppy track record and the disheartening prospects for its future success in changing Tehran's behavior, much less, its regime. Some observers even went so far as to suggest that a policy of hyper-securitization and its concomitant sanctions regime could further calcify Iran's recalcitrance by depriving Iran of much-needed "maneuverability" to rediscover and, with any luck, redefine itself. ${ }^{380}$ Partly bowing to these pressures and concerned that the ILSA's full implementation would widen the transatlantic difference of opinion on Iran, in 1997 the Clinton administration shied away, on national interest grounds, from penalizing Total SA of France, Gazprom of Russia, and Petronas of Malaysia which were developing the South Pars natural gas filed in Iran. ${ }^{381}$

\footnotetext{
${ }^{380}$ Jahangir Amuzegar, "Iran's Economy and the US Sanctions," The Middle East Journal 51, no. 2 (Spring 1997): 185-199.

${ }^{381}$ Kenneth Katzman, The Iran-Libya Sanctions Act (ILSA), (CRS Report for Congress, 2006).
} 
In the meantime, some policy experts were insisting that Washington go even further and overhaul its Iran policy by wooing the regime's potentially pro-west elements to its side. Anthony Cordesman of the Center for Strategic and International Studies (CSIS) argued, for example, that Washington stood a chance to make strategic gains by nurturing technocratic moderate elements in Tehran who didn't view the United States as a sworn enemy. ${ }^{382}$ This line of thinking was in accord with the "critical dialogue" formula that the Europeans were vociferously advocating while airing their displeasure at what they perceived was an ill-conceived containment formula that assumed parity between Iran and Iraq.

In view of the Europeans, since Washington's short history of engagement with Tehran had been mainly through oil, anti-communism and terrorism, its policy response to Iran's WMD challenge was blunt and lacked the kind of sophistication that would only come by paying attention to the country's vibrant civil society and political discourse. ${ }^{383}$ As one European diplomat put it, "Except for Turkey, Iran is the only real country in the region, with 3,000 years of history. It's a complicated country, with a real intellectual life. It's not Iraq." In light of these conceptual and operational pathologies, as far as the Europeans were concerned, the policy of dual containment had turned so dysfunctional that it was isolating the United States more than it was isolating Iran. ${ }^{384}$ These so-called cooler heads, however, had a snowball's chance in hell to prevail as whatever traction

\footnotetext{
${ }^{382}$ Sciolino, Elaine, Casting a New Iran in the Old Role of a Friend. The New York Times, September 22, 1996.

${ }^{383}$ Barry Buzan, "A Leader Without Followers? The United States in World Politics after Bush," International Politics 45 (September 2008): 554-570.

${ }^{384}$ Crumbling Walls: U.S. Effort to Isolate Both Iran and Iraq Is Fraying Badly, Steven Erlanger, The New York Times, 11 Nov 1997: 10.
} 
they managed to muster was neutralized with Defense Secretary William Perry pointing at an Iran link in the Khobar Towers bombing of June $1996 .{ }^{385}$

Furthermore, just as the White House efforts to bring its North Atlantic allies onboard with its securitization platform were looking futile, an opportunity to mobilize support and narrow down the differences presented itself. On April 10, 1997 a German court implicated high-ranking Iranian officials in the gangland-style assassination of the Iranian-Kurdish opposition leaders at the Mykonos restaurant in Berlin. An intense diplomatic crisis ensued when the Berlin court's verdict implicated high-ranking Iranian government officials in the incident. Shortly afterward, the EU countries summoned their ambassadors from Tehran signaling the end of "critical engagement" as Europe's longterm recipe to deal with Iran. The so-called Mykonos crisis, however, proved no more than a "passing storm"-in president Rafsanjani's words- as Germany recoiled into a crisis control mode and the election of moderate president Mohammad Khatami pushed IranEU economic relations to yet newer highs. ${ }^{386}$

Washington, on the other hand, showed no interest in re-formulating its singlemindedly securitizing paradigm that tended to treat an otherwise composite Iranian regime as a monolithic entity. For instance, as Iran's 1997 presidential campaign, with the reformist underdog Khatami on the ticket, were heating up, new Secretary of State Albright wasted no time during her first overseas tour to signal a continuation of active containment of Iran irrespective of who replaced president Rafsanjani. With her characteristically point-blank style, Albright castigated the Europeans, the Italians in

\footnotetext{
${ }^{385}$ The New York Times, August 9, 1996.

${ }^{386}$ Seyyed Hossein Mousavian, Iran-Europe Relations: Challenges and Opportunities (New York, NY: Routledge, 2008).
} 
particular, for their "critical dialogue" approach to Tehran and reminded her Chinese counterparts they couldn't have the best of both worlds: seek closer ties to Washington while trading in high-tech with Iran. ${ }^{387}$

On May 23, 1997, Mohammad Khatami pulled off an upset victory in a presidential election that saw a record $80 \%$ voter turnout. Washington's reluctance to try out a more imaginative approach to Iran was, in no small part, driven by the domestic political environment in the United States as well. Up against an intractable anti-Iran Congress led by house speaker Newt Gingrich and a consistently lackluster public opinion toward the clerical regime, the Administration kept shying away from a more interactive approach toward Tehran. ${ }^{388}$

Faced with these domestic constraints and wary of jeopardizing the precious little receptivity the Europeans had recently shown to the containment policy following the Mykonos crisis, the election of a reformist president was actually met by an intensified international campaign by the U.S. to curb Tehran's proliferation activities run amok in the judgment of the Clinton administration. Besides lodging the usual complaints with Moscow over its ballistic missile and nuclear cooperation with Tehran, now even a more substantial part of Washington's proliferation-curbing efforts were focused on Beijing which had ongoing nuclear projects in Iran, among them a small research reactor and a zirconium production facility for nuclear fuel rods. Those efforts finally bore fruit in October 1997 when the administration managed to extract a written pledge from China to terminate all nuclear cooperation with Tehran, except for the two mentioned projects that were deemed proliferation-neutral, in exchange for certification by Washington of a 1985

\footnotetext{
${ }^{387}$ United States: Iran Policy Oxford Analytica; Daily Brief Service, Feb 27, 1997.

${ }^{388}$ United States: Iran Opportunity, Oxford Analytica, Daily Brief Service. (Jun 04, 1997).
} 
nuclear cooperation agreement that would pave the way for exporting advanced U.S. nuclear technology and reactors to China. Despite Beijing's formal acquiescence, however, Washington, especially Capitol Hill, continued to view China as a "reluctant" partner at best and remained extremely skeptical of China's long-term commitment to forswearing all nuclear dealings with Iran. ${ }^{389}$ As a matter of fact, as The Washington Post's Smith Jeffrey indicated, the INP was so high on the agenda during the October 1997 Clinton-Zemin summit meeting that Washington essentially put on the backburner all other high-stakes issues in Sino-US relations just to secure a strategic concession on the INP. ${ }^{390}$

\section{A Shift from the BNPP to MRBMs}

In 1997 one could also notice a shift of focus in the ingredients and stylistics of Washington's securitization approach toward the INP. The change of focus came about, seemingly, due to the Clinton Administration's failure to ferret out conclusive evidence on Iran's purportedly "crash program" to go nuclear. In this year, through much closer intelligence sharing with Tel Aviv, the cutting edge of Washington's threat pronouncements moved away from a dispersed, low-key, and deliberately paced nuclear program that defied slam-dunk verifiability toward Tehran's ballistic missile program.

At this point, especially alarming to the Israelis was intelligence that Iran had acquired the technological knowhow to indigenize North Korea's No Dong missiles into Shahb-3 medium-range ballistic missile (MRBM) that would put Israel within its operational range. Interpreting this capability in purely offensive terms, the Defense

\footnotetext{
${ }^{389}$ Evan Medeiros, Reluctant Restraint: The Evolution of China's Nonproliferation Policies and Practices, 1980-2004 (Stanford University Press, 2007).

${ }^{390}$ The Washington Post, October 30, 1997.
} 
Intelligence Agency (DIA) endorsed Israeli intelligence prediction that the new missiles could come in the pipeline in a matter of 18 months. On a different front, openly irked at Russia's blasé attitude toward what he viewed a "vigorous" missile buildup, in September 1997 Vice President Al Gore asked his Russian counterpart Viktor Chernomyrdin to hold up his end of the 1995 Gore-Chernomyrdin bargain. ${ }^{391}$ This was a secret agreement concluded in June 1995 that called for Russia to terminate all "advanced conventional weapons" sales to Iran by 1999 in exchange for a pledge by Washington not to impose penalties on Moscow under the 1992 Iran-Iraq Arms Nonproliferation Act.

As a sense of alarmism over Iran's delivery capabilities was setting in, the Israelis, backed by AIPAC and an increasingly hawkish Congress, were relentlessly pushing the line that the Russians were in breach of the Gore-Chernomyrdin agreement and were, in the words of Prime Minister Netanyahu's director of policy planning David Bar-Illan, "very actively" in cahoots with Tehran on "both the transfer of knowledge and material." In Tel Aviv's judgment, by training Iranian students in missile technology, Moscow was basically putting Tehran in a position to have the capability to strike any target in Israel within a mere 18 months. ${ }^{392}$

The Tel Aviv-AIPAC-Congress axis had grown so momentous in 1997 that members of Congress were now openly accusing the Clinton Administration of a "consistent lack of candor and enforcement of arms control agreements with Russia." Republican House member Curt Weldon went so far as to introduce a bill that would require the U.S. government to contribute $\$ 110$ million to assist Israel's Arrow anti-

\footnotetext{
${ }^{391}$ The New York Times, November 28, 1997.

${ }^{392}$ Clinton Facing Clash of Policy On Iran Arms. Ira Stoll, Forward, November 7, 1997: 1.
} 
ballistic missile interceptor system "for the purpose of protecting a United States ally in imminent peril." Concerned that the Congress's obsessive focus and possible legislative action on the Iran-Russia missile nexus was threatening US-Russia relations at the strategic level, the Clinton Administration mobilized Assistant Secretary of State for Near Eastern Affairs, Martin Indyk, and the Deputy Assistant Secretary of State for Nonproliferation, Robert Einhorn to appease the AIPAC and Congress. 393

Washington's efforts to deny Iran a nuclear weapons delivery capability were not limited to Tehran's missile acquisition efforts, however. In a rather unusual move to beat Tehran to the punch, on November 5, 1997 Secretary of Defense William S. Cohen announced that the United States had bought 21 Soviet-era MIG-29 fighter aircraft from Moldova over concerns Tehran was eyeing them. ${ }^{394}$ Fourteen of these jet fighters were of the high-performance nuclear capable MIG-29C model that disconcerted Washington the most and prompted the deal's inclusion in the Nunn-Lugar Cooperative Threat Reduction (CTR) program conceived in 1992 within the Department of Defense to decommission the FSU's WMD stockpiles.

This heightened securitization of Iran's missile capabilities widened the transatlantic rift even further. Within this context, the European prescription, especially after the enthusiastic election of President Khatami in a referendum-like victory for the reformist movement in Iran, was to seize on the opportunity and start a genuine forwardlooking dialogue with the moderate pro-change forces through persuasion rather than coercion. Rallying support for such a long-term strategic objective was next to impossible

\footnotetext{
${ }^{393}$ Clinton Facing Clash of Policy On Iran Arms. Ira Stoll, Forward, November 7, $1997: 1$.

${ }^{394}$ The New York Times, November 5, 1997.
} 
in Washington though as a relentless barrage of intelligence reports was being leaked to the media on Tehran's ballistic missile shenanigans and its apocalyptic implications for Israel once married to a nuclear capability. As a matter of fact, the framing of Iran's missile capability as constituting an existential threat to the state of Israel had assumed such formidable momentum at this point that even the efforts of Prime Minister Netanyahu to resurrect "the doctrine of the periphery" failed to make much desecuritizing dent in the ingrained paradigm in Washington and Tel Aviv. ${ }^{395}$

\section{Conclusion}

In this expediency period, although the elimination of Saddam's imminent threat (in 1991) decidedly moved Tehran's behavioral and rhetorical attitude towards one of pragmatic sophistication, a lack of a commensurate reward mechanism by Washington continued to produce suboptimal results for Clinton's Tehran policy. Tehran found this attitude particularly malevolent. For example Tehran's February 1995 formal announcement that it would sign the NPT "despite the flaws in the treaty" ${ }^{\prime 36}$ generated almost no resonance in the broader scheme of threat judgments meted out to it. The Clinton administration's failure to reciprocate Tehran's goodwill gestures, arguably in the most formative years of Iran's post-War nuclear socialization in the mid 1990s, had an indelible impact in sedimenting the notion in Tehran's conservative power corridors that the nuclear dossier was only incidental to the more profound regime-type bone of contention the U.S. had with the Islamic Republic.

\footnotetext{
${ }^{395}$ For more on the doctrine of periphery and Netanyahu's efforts, see Trita Parsi, Treacherous Alliance: The Secret Dealings of Israel, Iran, and the United States (Yale University Press, 2007).

${ }^{396}$ BBC, Summary of World Broadcasts, 21 January 1995 quoted in Gary Sick, "Iran: The Adolescent Revolution ," Journal of International Affairs 49, no.1 (Summer 1995): 145-166.
} 
Presented with the all-important dilemmatic question of whether the United States was against a nuclear Iran or a nuclear Islamic Republic of $\operatorname{Iran}^{397}$, the proponents of this paradigm- that culminated in the presidency of Mahmoud Ahmadinejad in 2005- strongly favored the latter. The intertwinement of the securitization of the INP with regime change in the mid 1990s essentially removed deterrence as a de-securitizing and stabilizing element in Iran's relations with the United States.

Another factor deepening the securitization of the INP in this period came through a change in the composition of the nuclear decision-making circle in Tehran. Although the Rafsanjani Administration (1989-1997) tried in earnest to place Iran's nuclear decision-making at the policy level under civilian leadership and to present a united and unequivocal front on Tehran's lack of interest in pursuing the nuclear weapons option, the IRGC's occasional excursions into the domain betrayed that there was more to the INP than met the eye. As a matter of fact, one can track the initial signs of the IRGC's involvement in the nuclear decision-making to the early years of Ayatollah Khamenei's Supreme Leadership in the early 1990s. Mohsen Rezai was perhaps the first prominent military figure that weighed in on the issue in the public domain. The IRGC Chief Commander's sentiments on the issue, however, were in keeping with the official line coming out of Tehran. For example, in an interview with the Iranian daily Tehran Times in 1994 he cited "political logic, moral concerns and world realities" as determinants "stopping” Iran from acquiring a nuclear capability. ${ }^{398}$

\footnotetext{
${ }^{397}$ For more on this important distinction, see Henry Kissinger, "The World Affairs Council National Conference on Islam and the West" (Philadelphia, PA: World Affairs Council of Philadelphia, May 2005).

${ }^{398}$ Peter Feuilherade, "Iran: Nuclear Conundrum," The Middle East 1, no. 236 (July 1994).
} 
The IRGC's closer involvement in the INP resulted in the bifurcation of Tehran's nuclear efforts into two parallel programs: A core civilian nuclear program predominantly oriented toward resurrecting the Bushehr power plants under the authority of the AEOI and a peripheral sanctions-busting enterprise run by the IRGC geared toward securing technology, material, and components to keep a surge capacity a feasible option. As expected, there was ever-increasing overlap between the two domains over the next two decades as along with the deepening securitization of the INP the IRGC assumed a more strategically consequential role, along the way marginalizing and almost consuming the AEOI in the late 2000s.

The coming to power of the Clinton Administration further accelerated the securitization drift of the INP as the language of "existential threat" crept into Israeli and US discourse on Iran's nuclear enterprise. The Clinton Administration's strategy of choice to signal this heightened sense of alarm over the INP was one of putting more biting teeth into the sanctions regime already in place. The resultant Iran and Libya Sanctions Act of 1996 essentially torpedoed a pending \$1billion deal between a Dutch subsidiary of Conoco Oil Company and Iran to develop the Sirri oil field and marked the total departure of Iran-US relations from the economic zone.

In an interview with Mike Wallace in March 1997 an otherwise levelheaded president Rafsanjani could hardly hide his frustration at the fact that the leader of the capitalist world had written off its commercial interests over what Rafsanjani perceived was an ideological dispute. ${ }^{399}$ Equally shocking to the Iranians was the fact that their first major move toward normalization and joining the so-called Washington Consensus -

\footnotetext{
${ }^{399}$ President Hashemi Rafsanjani, interview by Mike Wallace, 60 Minutes, (March 8, 1997). http://www.cspanvideo.org/program/79946-1 (Accessed July 25, 2011)
} 
opening up their energy sector to international oil companies following the 1979 revolution- was being spurned and aborted by Washington upon arrival.

Another important factor that made Washington's securitizing moves partially successful in the era was a conspicuous lack of a democratic and diffuse domestic debate on the pros and cons of the nuclear option in all its manifestations. In the eyes of the majority of the Western states, the history of proliferation was rife with a tendency to go for the bomb in countries where a tightly knit nuclear decision-making apparatus operated in the shadows. Iraq under Saddam, Pakistan under Zulfikar Ali Bhutto, Israel under David Ben-Gurion, and South Africa under the apartheid rule were a few examples substantiating this notion. Although Tehran, well aware of the securitizing implications of hush-hush nuclear politics, embarked on a controlled opening up of the public space to the INP toward the late 1990s, this endeavor was largely unsuccessful in generating a vibrant public dialogue on the issue. This failure had to do as much with the democratic deficits of a theocratic system that tapped into the public space ex post facto for symbolic reasons as with the fact that it never went beyond a public opinion manipulation tool to genuinely make the public part of the country's nuclear conversation.

Further complicating the task of placing the INP on a popular mandate by the Iranian government was an inherent clash-whether perceived or real- between the foundational myth of Tehran's clerical regime (as an Islamic Republic) and a rekindling of nationalistic fervor imperative for rallying the public around the nuclear flag. Supreme Leader Ayatollah Ali Khamenei's personal apprehension, lest Iran reverted into a runaway nationalistic mood, was highly visible in this regard. In any case, one could hardly overestimate the degree to which excluding the general public from the nuclear 
debate facilitated the targeting of the INP for securitization by the United States and the West.

Despite being up against insurmountable odds, Tehran was hard at work in the late 1990s trying to forestall Washington's securitizing posture vis-à-vis the INP from becoming mainstream international wisdom. President Khatami's recipe to ease the stifling pressure was a policy of détente toward the international system in general and the Persian Gulf Arab States in particular. The culmination of this policy at the regional level was Tehran's much-publicized hosting of the Organization of the Islamic Conference (OIC) summit in December 1997, the largest international event held in Iran after 1979 with over 50 member states in attendance. The détente policy had some limited success in diffusing the security energy of the INP at the international level as well when the Europeans saw an opportunity to seize on the moment and start a persuasive and forward-looking dialogue with Tehran's moderate pro-reform forces. 


\section{CHAPTER 6}

\section{7-2011: NUCLEAR APPEASEMENT \& FLAMBOYANCY}

\section{Introduction}

Arguably the most consequential impact of the election of President Khatami in 1997 was demonstrating to the international community Iran's capacity to normalize and redeem itself from within. Khatami's recipe to showcase this capacity and ease the stifling pressure on Tehran was a policy of détente toward the international system in general and the Persian Gulf Arab States in particular. As mentioned in the last chapter, the culmination of this policy was Tehran's much-publicized hosting of the Organization of the Islamic Conference in December 1997, the largest international event held in Iran with over 50 member states in attendance.

As détente was yielding moderate results in de-securitizing the INP, however, the apocalyptic 9/11 attacks threw Iran's nuclear program back into the military extreme of the securitization spectrum. The Bush Doctrine that emerged out of those attacks diagnosed the intersection of technology and ideology as the most intractable national security challenge facing the United States in the $21^{\text {st }}$ century. In order to avert a nuclear 9/11, preventive war was the prescribed policy as promulgated in the 2002 National Security Strategy of the United States. The strategy's implications couldn't have been graver for Iran's nuclear program as President Bush placed Tehran front and center in the doomsday WMD-terrorism-tyranny triangle in his January 2002 “axis of evil” speech. 
As Iran was coming to grips with the dizzying pace of events surrounding its nuclear program, in August 2002 an Iranian opposition group sent shockwaves through the INP by exposing two secret nuclear sites at Natanz and Arak. These revelations marked the beginning of the comprehensive securitization of the INP at the international level. Before long and as Tehran was trying to finesse its way out of the NPT noncompliance accusations, the doctrine of preventive war found its first kinetic applicability in Iraq as the United States launched Operation Iraqi Freedom (OIF) to neutralize Saddam's purported WMD capabilities. The Iraq War of March 2003 pushed, if only by association, the Iranian nuclear program even deeper into the military extreme of the securitization spectrum.

\section{Khatami's Era}

Khatami's détente policy, did not mean that Iran had stopped its shop-till-youdrop nuclear policy of scouring the market to get its hand on as much nuclear heardware and software as possible before the post-Soviet collapse black-market closed. On a more formal level, Iran's relations with Russia were on a progressively upward trajectory in the late-1990s as Moscow was increasingly viewing the "Oriental states" as a counterweight to Washington's eastward expansion through NATO's incorporation of the Eastern European members.

For example, during a high-profile visit by Ali Akbar Nateq Nouri, Iran's parliament speaker to Moscow in April 1997, Russian President Boris Yeltsin cordially referred to Tehran-Moscow ties as a "positive cooperation" that "showed a tendency to grow.” The same sentiments were voiced even more vociferously by Gennadi Seleznyov, the Communist speaker of the Russian Parliament during a press conference with Nateq 
Nouri when Seleznyov put Iran's embattled relations with Western Europe following the Mykonos crisis as part of "the West's intrigue against the East." ${ }^{400}$ Tehran, for its part, was incrementally viewing its ties to Moscow in a strategic light especially in terms of Russia's capacity to keep in check the securitization thrust of its nuclear endeavor.

As the military and nuclear cooperation between Tehran and Moscow was accelerating, the contours of a polarizing and heated debate in Washington on the longterm implications of a nuclear Iran were crystallizing. On the one extreme, were Iran hawks in both Israel and the United States whose Iran analyses were frequently punctuated by the word "apocalypse," as in their view nuclear weapons could only further embolden a reckless Tehran to defy the norms of responsible international behavior by granting it a critical zone of immunity.

On the other extreme, however, were the more hardheaded Iran realists who believed nuclear weapons would actually have a sobering impact on Tehran's foreign policy rhetoric and behavior. This latter view was not lost on some authoritative voices inside the state of Israel whose panic button on a nuclear Iran was deemed the quickest to go off. For instance, Martin van Creveld, a renowned Israeli military historian, went so far as to make an analogy between Iran and China on the issue: "When Mao and Stalin acquired nuclear weapons, they calmed down," he observed, adding "If Islamic states get the bomb, the effect will be the same. Once you have the 'absolute weapon,' war ceases to be fun. It becomes suicide." ${ }^{401}$

\footnotetext{
${ }^{400}$ The New York Times, April 12, 1997.

${ }^{401}$ The Christian Science Monitor, July 30, 1997.
} 
Foreign policy realists' sentiments on the feasibility of deterring Iran, however, were quick to be drowned out as a deluge of doomsday prognostications about the INP soon overwhelmed the international public square. This came about in late 1997 as Israel's Mossad went public with its intelligence on Russia's secret nuclear and ballistic missile technology transfers to Tehran previously only shared with the Defense Intelligence Agency (DIA). In a series of articles in The Washington Times, Bill Gertz catalogued Russia's non-compliance with the 1995 Gore-Chernomyrdin deal on arms proliferation to Tehran. The visibly miffed Clinton Administration, under pressure from the Congress and the AIPAC, dispatched Al Gore to Moscow who publicly criticized Russia and Prime Minister Chernomyrdin over Iran's "vigorous" ballistic missiles and nuclear technology procurements.

Washington, in this period, was especially concerned by the intelligence reports that the FSU's cash-strapped scientific community was being lured and recruited into Iran's military-nuclear industrial complex enabling Tehran to indigenously master the full range of nuclear and ballistic missile options. Moscow, careful not to let the controversy derail its strategic ties with Washington, relieved head of the Russian arms export agency (Rosvooruzhenie) Aleksandr Kotelkin of his post among accusation of corruption and promised to clean up the agency of the bad apples. ${ }^{402}$

If Washington's negotiations with Russia over transfer of WMD-relevant technology to Iran were yielding little concrete results, in October 1997 the Clinton Administration scored a major victory with China. Following months of an intense diplomatic effort spearheaded by National Security Council Director for Nonproliferation

${ }^{402}$ The New York Times, September 28, 1997. 
Gary Samore and Deputy Assistant Secretary of State Robert Einhorn, Beijing pledged to drastically and verifiably curtail its nuclear and missile cooperation with Iran and, more broadly, bring its nuclear exports in line with the international nonproliferation regimes, especially Article III of the NPT, by formally joining the Zangger Committee (A.K.A. the Nuclear Exporters Committee). This concrete written commitment by Beijing would pave the way for President Clinton to authorize the transfer of advanced civilian nuclear technology and rectors to China. ${ }^{403}$

The devil-in-detail problem however again reared its head despite the conclusion of the deal in the Jiang Zemin-Clinton summit meeting of October 30, 1997 when Iran hawks in the U.S. Congress criticized the agreement for failing to incorporate the two nuclear projects China had already undertaken in Iran. These two projects included "a small research reactor and a factory to manufacture a special metal sheath -- known as zirconium cladding -- for nuclear fuel rods." Ever skeptical Congressional hawks were demanding the Administration seek the termination of these projects and include the banning of cruise missile sales to Iran as part of a comprehensive package. ${ }^{404}$

In the meantime, as a sense of resignation was creeping into Washington's strategic assessment of the prospects for consequentially sanctioning and isolating Iran, a new wave of clamor in the United States was pushing for diplomacy and dialogue with Iran now that a moderate president Khatami was trying to "remove tensions" from Tehran's foreign policy. In a Foreign Policy piece, Robin Wright and Shaul Bakhash echoed the sentiments expressed by numerous "former senior U.S. officials-both

\footnotetext{
${ }^{403}$ The Washington Post, October 27, 1997.

${ }^{404}$ The Washington Post, October 30, 1997.
} 
Republican and Democrat-from the National Security Council, the State Department, and the Central Intelligence Agency" who "publicly urged Washington to test the waters of constructive engagement through either European allies or direct dialogue." 405

Reflecting the same sentiments and taking issue with hawkish opponents of diplomacy with Iran who saw Tehran's penchant for proliferation as part of the DNA of the clerical regime, Graham Fuller, former Vice Chairman of the National Intelligence Council at the CIA observed, "If a U.S.-Iranian rapprochement can come about--and this is not unattainable--it will go a long way toward lessening the intensity of Iran's need to develop these weapons or to use them against the U.S. or its allies. A rapprochement indeed takes two, but Washington must appreciate that Iran's weapons quest is as much the result of the present U.S.-Iranian hostility as it is the cause."

Comments by President Khatami in a December 1997 interview with CNN on the need for Iran and the U.S. to create a "crack in the wall of mistrust" between the two states by engaging in a "thoughtful dialogue" helped further de-escalate the mounting tensions. Shortly afterward, Clinton dropped a de-securitizing line of his own by reciprocating Khatami's olive branch: "I would like nothing better than to have a dialogue with Iran," Clinton vowed. ${ }^{407}$ As an aura of rapprochement between Tehran and Washington was gaining momentum at least at the executive level, calls in Washington for directly engaging Khatami's Iran, as the US did with China, were growing more vocal. In this transforming atmosphere, some Clinton White House officials went so far

\footnotetext{
${ }^{405}$ Shaul Bakhash, Robin Wright, "The U.S. and Iran: An Offer They Can't Refuse?," Foreign Policy, no. 108 (Fall 1997): 124-137.

${ }^{406}$ The Los Angeles Times, January 14, 1998.

${ }^{407}$ The Wall Street Journal, December 16, 1997.
} 
as to praise Iran's "key role in shaping" the December 1997 OIC Summit Conference's final communiqué that explicitly "condemned terrorism, called for dialogue between Islam and the West and -- significantly -- didn't call for lifting U.S.-supported sanctions against Iraq." ${ }^{408}$ These calls for engagement managed to gain even some operational traction in the Clinton Administration when the President decided not to impose sanctions on French energy group Total for investing some \$2 billion in Iran's natural gas fields. Now, there was talk in Washington of charting a new path with Iran analogous to SinoAmerican rapprochement in the Nixon Administration. ${ }^{409}$ On the nuclear front too, President Khatami categorically denied Iran's desire to become a nuclear weapons state and pledged his Tehran's commitment to cooperate with the IAEA.

These conciliatory gestures and the accompanying new ground broken by Tehran and Washington, however, fell well short of bringing about a Gorbachev-Reagan-like sea change in Iran-US relations as foreign policy hawks in both capitals regained command of the discourse. In Tehran, the hardliners closely affiliated with Supreme Leader Ayatollah Khamenei threw into doubt the revolutionary credentials of President Khatami, likened him to Gorbachev as a westoxicated and intimidated figure (Mar'oob), and accused him of derailing the Iranian Revolution from its anti-imperialist right path. In Washington, foreign policy hawks were scoffing at the naïveté of Clinton's putative policy of dialoguing with Iran and claiming, "dialogue is an instrument of policy, not a policy." Peter Rodman of the Washington Post wrote," The conflict between Iran and the United States has been a clash of fundamental purposes -- Iran's assault on Western positions in the Middle East, its pursuit of weapons of mass destruction, its sponsorship

${ }^{408}$ The Wall Street Journal, December 16, 1997.

${ }^{409}$ Eldon Griffiths, "Let's treat Iran Like China," World Trade 11, no. 1 (January 1998). 
of terrorism and hostility to Arab-Israeli peace, and our resistance to the same. It is naive and absurd to think that these issues are a product of misunderstanding or a failure of communication." $" 410$

The ongoing tug of war in Washington on whether to isolate or engage Iran continued up until President George Bush's “axis of evil” speech of January 2002. The nest result of this lack of unity of purpose on Iran was the relaying of conflicting punishment and reward signals by Washington to Tehran, a misaligned and rudderless policy where carrots and sticks neutralized, rather than reinforced, each other. For instance, in June 1998, Secretary of State Albright, seemingly intrigued by Khatami's extended hand for dialogue, observed, Iran "is participating in diplomatic efforts to bring peace and stability to Afghanistan and is making a welcome effort to improve relations with Saudi Arabia and other neighbors in the [Persian] Gulf," adding "we are ready to explore further ways to build mutual confidence and avoid misunderstandings."411 These comments were expressed about the same time when Bruce Riedel, "the top Iran policy official on the National Security Council" emphasized the need to "maintain a policy of seeking to constrain the dangerous behavior of Iran," citing Tehran's opposition to the Middle East peace process, while trying to see if the changes in Tehran offer an opportunity for a better long-term relationship." In the meantime, he was emphasizing Iran's continued status as "the principal state sponsor of terrorist groups throughout the region." 412

\footnotetext{
${ }^{410}$ The Washington Post, December 24, 1997.

411 The Washington Post, June 18, 1998.

${ }^{412}$ The Washington Post, June 18, 1998.
} 
Faced with the double-dilemma of conflicting signals issued by Washington and the power struggle in Tehran between the reformists (who saw a normalization of ties with the United States as a natural extension of Khatami's policy of détente) and the conservative old guard (who saw anti-Americanism as one of the defining and indispensible features of the Iranian Revolution), Khatami's foreign policy team demanded the White House operationalize its conciliatory rhetoric by easing sanctions on Tehran and dropping its opposition to the passage of the Caspian Basin oil pipelines through Iranian territory.

For instance, Iran's Deputy Foreign Minister and later UN Ambassador Mohammad Javad Zarif observed, "We see a move at least in rhetoric on the part of the United States to better understand the realities of the Islamic Republic as well as of our region," before adding, "Where it matters, where it will be taken seriously by Iran -regarding the policies of the United States, the behavior of the United States -- we see the remnants of a Cold War mentality." Especially disturbing to the Iranians, in this regard, were ubiquitous allusions by the U.S. officials to Iran's attempts at acquiring Weapons of Mass Destruction. ${ }^{413}$ These speculative WMD allegations, in Tehran's judgment, were symptomatic of the fact that the United States' Iran policy had become hostage to the Israel factor and betrayed Washington's psychological unpreparedness to disengage itself from the weight of history and embark on a de-securitized path with Iran.

As the Clinton Administration was showing all manner of confusion on how to deal with Iran, the tentative atmosphere for rapprochement took a double hit in 1998. First came news in July 1998 that Iran had test fired a strategic medium-range ballistic

${ }^{413}$ The New York Times, June 26, 1998. 
missile (MRBM) with a range of 800 miles. This would put Israel within the operational range of the liquid-propellant missile. Second, was an unprecedented move by federal prosecutors in New York who, for the fist time, publicly accused Iran of giving operational training to members of Osama bin Laden's Al-Qaeda organization that had "sent emissaries around the world in an effort to procure nuclear weapons.",

The combined result of these twin events was the paving of the way in Israel and the United States for the designation of Iran's nuclear program as an "existential threat." It was within such an atmosphere that Efraim Sneh, a Labor Party hawk in the Israeli Knesset speculated that a "pre-emptive strike" on Iran might become imperative since "international efforts to prevent Iran from acquiring missile technology and developing a nuclear capability had failed." Following Sneh's remarks, Israeli Defense Minister Yitzhak Mordechai quickly rejected the military option out of hand. ${ }^{415}$

In the meantime, Washington's relations with Moscow were precipitously souring as different elements in the Clinton Administration, the US intelligence community, and the Congress were accusing Kremlin of either complicity or criminal negligence over the steady outflow of nuclear technology, scientists, and hardware to the rogue states. Matters reached a fever pitch in January 1999 when White House national security adviser Sandy Berger announced unilateral U.S. sanctions on three Russian institutes, Scientific Research and Design Institute of Power Technology, the Mendeleyev University of Chemical Technology, and the Moscow Aviation Institute.

Moscow's reaction to these measures was uncharacteristically trenchant. A Foreign Ministry statement termed "any attempts to speak with [Russia] in the language

\footnotetext{
${ }^{414}$ The Washington Post, September 26, 1998.

${ }^{415}$ Jewish Telegraphic Agency, September 28, 1998.
} 
of sanctions and pressure" "absolutely unacceptable" and vowed retaliation. The Communist Party leader was far less diplomatic in lashing out at the U.S. punitive measures: "The United States of America has imagined that they are a gendarme, prepared to dictate conditions not only to countries, bombing foreign states, but to ban, and even to dictate conditions to, separate universities and scientific laboratories," Gennady Zyuganov vented. ${ }^{416}$

One could call 2000 a watershed year in Iran's relations with the Russian Federation. After Vladimir Putin assumed presidency in May 2000, Moscow wasted little time notifying Washington of its intent to rescind a 1995 deal with the United States to mothball new battlefield weapons contracts with Iran. Almost immediately following that came another blow for the lame duck Clinton's dual containment policy. In December 2000, Russian Defense Minister Igor Sergeyev made a three-day official trip to Iran, the first official visit by a Russian defense chief to Tehran since the 1979 Revolution. During the high-profile visit, which included meetings with President Khatami and Iran's Defense Minister Rear Admiral Ali Shamkhani, a publicly defiant Sergeyev expressed great satisfaction at the termination of the 1995 pact that had caused a "great pause" in Tehran-Moscow military cooperation and reassured his Iranian counterpart that "there will be no pauses from now on." ${ }^{.417}$

The termination of the secret Gore-Chernomyrdin agreement and the strategic trajectory of Tehran-Moscow ties became even more manifest during a high-profile state visit by President Khatami to the Kremlin in March 2001. This marked the highest-

\footnotetext{
${ }^{416}$ The Washington Post, January 14, 1999.

${ }^{417}$ The Washington Post, December 29, 2000.
} 
ranking meeting between the two countries in almost four decades. During the visit President Putin officially announced Russia's agreement to resume the sale of conventional weapons to Iran and reiterated his country's commitment to complete the Bushehr Nuclear Power Plant. In some candid remarks bound to rankle Washington and Tel Aviv, Putin commented, "politically, Iran should be a self-sufficient, independent state that is ready to protect its national interests." ${ }^{418}$

The resumption of ballistic missile cooperation between Tehran and Moscow in this period finds even a more strategic context once analyzed against the backdrop of the newly sworn-in President Bush's plans to pull out of the 1972 Anti Ballistic Missile (ABM) treaty (long deemed an indispensible nuclear arms control keystone) and erect a National Missile Defense (NMD) system aimed at shielding the United States from nuclear blackmail by rogue states like Iran and North Korea. The Bush Administration's decision to withdraw from the treaty and forge ahead with the NMD as an "urgent" military objective, spearheaded by Secretary of Defense Donald Rumsfeld, was a clear indication that Washington was giving up hope, at a strategic level, on the Russian Federation's non-proliferation bona fides. ${ }^{419}$

Within this strategic context, the Bush Administration's first specific encounter with Iran came in mid-2001 when the Iran-Libya Sanctions Act (ILSA) was due to expire in August after five years in effect. Faced with the dilemma of renewing or easing the ILSA, Bush's response was one of muddling through. This was a clear sign that the Administration's Iran policy was yet to coagulate. "As far as Iran goes, it's too early at

\footnotetext{
${ }^{418}$ The New York Times, March 13, 2001.

${ }^{419}$ The Christian Science Monitor, March 14, 2001.
} 
this time in our relationships to really -- I mean, it's one thing to consider, it's another to act, to act on sanctions, and I don't intend to do that anytime soon," the President equivocated. $^{420}$

A few months after these remarks came the 9/11 attacks in New York City and the Washington D.C area that marked a major reorientation in the U.S. foreign policy toward the rogue states. Iran's initial response to the attacks was a guarded expression of sympathy coupled with promises of intelligence sharing and operational cooperation with Washington in sweeping the Taliban and Al-Qaeda out of Afghanistan. The commonality of interests was further reinforced in the UN-brokered and US-sponsored Bonn Conference in December 2001 aimed at creating an interim Afghan government when Iran threw its weight behind the U.S. candidate for Afghan presidency Hamid Karzai and extended a cooperative gesture toward Washington's nation-building strategy in Afghanistan.

The Bush Administration, however, failed to reciprocate these goodwill gestures, as the new paradigm of the "Global War on Terrorism" (GWoT) reigned supreme in Washington. It was within this context that Iran was promoted from a rogue state to a member of the "axis of evil" in George Bush's 2002 State of the Union address. ${ }^{421}$ The president, in the speech, placed Iran, along with Iraq and North Korea, at the intersection of a hostile ideology and a penchant for acquiring WMD. This, in Bush's judgment, rendered Tehran "a grave and growing danger" against which a pro-active preventive policy was imperative. "I will not wait on events while dangers gather," the President

\footnotetext{
${ }^{420}$ The Washington Post, April 20, 2001.

${ }^{421}$ The New York Times, February 10, 2002.
} 
said, before warning, "The United States of America will not permit the world's most dangerous regimes to threaten us with the world's most destructive weapons." ${ }^{422}$ This speech, institutionalized in the Bush Administration's national security documents of 2002 and 2006, marked the militarization drift of the Iranian nuclear program and set the stage for the language of "surgical strike" to enter the United States' Iran terminology.

Triumphant and euphoric, following the impressive success of Operation Enduring Freedom in sweeping the Taliban from power and shortly after the President's "Axis of Evil" speech, Washington initiated a concerted effort to accelerate the militarization of the threat package issuing from Tehran. In February 2002 Secretary of Defense Donald accused the Iranian government of obstructing Washington's antiterrorism campaign. "We have any number of reports that Iran has been permissive and allowed transit through their country of Al Qaeda," Rumsfeld said. ${ }^{423}$ Reflecting the same sentiments, National Security Adviser Condoleezza Rice placed Iran front and center in Washington's most urgent security concerns following the 9/11 attacks: nuclear terrorism. "Iran's direct support of regional and global terrorism, and its aggressive efforts to acquire weapons of mass destruction, belie any good intentions it displayed in the days after the world's worst terrorist attacks in history," Rice said.

Tehran interpreted the Bush Administration's combative language as indicative of the fact that Washington was aggressively incubating a "regime change" policy vis-à-vis Tehran. In a letter to U.N. Secretary General Kofi Annan, Iranian Foreign Minister Kamal Kharrazi registered Tehran's "strong indignation" at the Bush's State of the Union

\footnotetext{
${ }^{422}$ The Los Angeles Times, January 30, 2002.

${ }^{423}$ The Los Angeles Times, February 4, 2002.
} 
address and the Administration's escalatory follow-up remarks. The letter took to task the fundamentals of the GWOT paradigm and Iran's placement within it as a nuclear proliferator. It labeled the GWOT as a "self- centered, unilateral and naive" policy smacking of imperial hubris that utilized "threat or use of force against what the United States has arrogated to itself to call terrorism."

In Iran's judgment such an arbitrary policy "undermined the global resolve to embark on a real and comprehensive war on terrorism" and made it look like the United States was "confronting the entire Islamic world." ${ }^{424}$ The cumulative impact of this new atmosphere was enervating the overall energy of Iran's foreign policy under Mohammad Khatami otherwise geared towards bringing Iran back into the international fold.

In the meantime, Tel Aviv found in the GWOT and the United States' growing animosity toward Tehran a most hospitable ground to push for internationalizing the securitization of the INP. In New York, Israeli Foreign Minister Shimon Peres accused Iran of developing nuclear weapons and supplying Hezollah with medium-range missiles. The Foreign Ministry also launched an international campaign by "preparing a letter for Israeli ambassadors to present to foreign governments urging them to cut ties with Iran if it doesn't stop developing missiles and nonconventional weapons. ${ }^{\not 25}$

These provocative developments and escalating expressions of mutual hostility were progressively feeding into the militarization energy of the INP. Now, Iran was publicly concerned that Israel was hatching operational plans to unleash a military strike on its nuclear facilities analogous to Operation Opera against Osirak in 1981. Iranian

\footnotetext{
${ }^{424}$ The Washington Post Feb 6, 2002.

${ }^{425}$ The Los Angeles Times, February 6, 2002.
} 
Defense Minister Ali Shamkhani's response to these speculations was unmistakably defiant: "If Israel carries out any military action against Iran, it will face a response that will be unimaginable to any Israeli politician," the Rear Admiral threatened. ${ }^{426}$

In such an atmosphere, the Europeans were equally confused and shocked as the Iranians on what was driving the Bush Administration's newfound militant policy against Tehran. In remarks indicative of the growing transatlantic rift on the GWOT and the extent of its applicability to Tehran, a senior EU diplomat observed, "Bush can say what he likes and we listen to him. But we've seen in the past how Washington's policy of containment with regard to Iran and Iraq has led nowhere. We have our own foreign policy interests as much as the US has its own." Another EU diplomat put Europe's sense of loss and dismay at where Washington was going with its new saber-rattling Iran policy in most disarmingly simple terms: "We don't get [it] with Washington. One day, the US praises Iran for its part in the post September 11 war against terrorism. The next day, as Condoleezza Rice said herself, Iran's aggressive efforts to acquire weapons of mass destruction, belie any good intentions it displayed after September 11. Is that a foreign policy?" 427

As the securitization thrust of the INP was precipitously moving upward, another shock in mid-August 2002 pushed Iran's nuclear program deeper into the military zone. On August 15, 2002 came revelations by the Iranian opposition group the National Council of Resistance of Iran (NCRI) with links to the terrorist organization Mojahedine-Khalq Organization (MEK) accusing Iran of secretly building a nuclear enrichment

\footnotetext{
${ }^{426}$ The Los Angeles Times, February 6, 2002.

${ }^{427}$ The Financial Times, February 5, 2002.
} 
facility at Natanz and a heavy water plant in Arak. ${ }^{428}$ Following the whistle blowing, the IAEA insisted on inspecting the sites, especially the Natanz facility.

The IAEA director reported to the Board of Governors the startling progress Iran had made in terms of the scale of its undeclared nuclear activities. In the words of the IAEA Director General, two aspects of the Natanz facility were especially disconcerting: "The first was the scale of Iran's nuclear ambitions, which required a sharp reassessment on our [IAEA] part. Up to this point the hallmark of Iran's nuclear program had been one power reactor under construction at Bushehr, for which Russia had contracted to supply the enriched uranium fuel. But Natanz, when fully operational, would have the capacity to supply the fuel for two to three one-thousand megawatt reactors. What other facilities was the AEOI planning or constructing? The second aspect was still more disconcerting. Aghazadeh [the AEOI Chairman] told us [IAEA inspection team] that Iran's centrifuge development program was entirely indigenous." ${ }^{429}$

The timing of these revelations couldn't have been worse for Iran as they coincided with mounting U.S. push to launch the first counter-proliferation war on Iraq on March 20, 2003 and North Korea's announcement of withdrawal from the NPT on January 10, 2003. The military implications of the clandestine aspects of Iran's nuclear program were not lost on the Iranians either, as soon following the uncovering of the two nuclear facilities and Tehran's lackluster and lethargic cooperation with the IAEA, the United States unleashed Operation Iraqi Freedom on March 20, 2003 removing Saddam Hussein from power over allegations of a WMD program.

\footnotetext{
${ }^{428}$ The New York Times, August 15, 2002.

${ }^{429}$ Mohamed Elbaradaei, The Age of Deception: Nuclear Diplomacy in Treacherous Times (New York, NY: Metropolitan Books, 2011).
} 
Tehran, concerned it would be the next target in the Bush Administration's regime change master list, wheeled into action by trying to undertake whatever initiatives it could to de-securitize its nuclear profile. Iran's de-securitizing strategy was two pronged: First was an international confidence-building and credibility-restoration campaign to scatter the clouds of apprehension surrounding its nuclear program and threatening to poison its relations even with Russia. Second, was an under-the-counter effort to strike a comprehensive threat reduction package deal directly with the United States.

On the first front, Tehran agreed, within the Tehran Declaration of October 21, 2003 and the follow-up Paris Agreement of November 14, 2004 to furnish the IAEA with full information on its nuclear profile, temporarily and voluntarily suspend all enrichment and reprocessing activities, broadly conceived, and abide by the provisions of the 1997 IAEA Additional Protocol that enabled the Agency to conduct more intrusive inspections of Iran's declared and undeclared facilities and activities, including its laser enrichment, reprocessing, and heavy water projects.

Coming on the heels of these trust-building measures by Iran, ElBaradaei's November 10, 2003 report to the IAEA Board of Governors on the INP was nothing if not equivocal. The Director General, on thin ice with Washington over his position on Iraq's WMD program and accused of having a pro-Iran bias by John Bolton, the U.S. Undersecretary of State for Arms Control and International Security, concluded his report by confirming Iran's non-diversion of nuclear material for weaponization purposes. This key judgment by the IAEA, much to Washington's chagrin, put Iran in the ballpark as far as its compliance with the NPT was concerned. El Baradaei wrote, "to date, there is no 
evidence that the previously undeclared nuclear material and activities ... were related to a nuclear weapons program," before adding the caveat, "However, given Iran's past pattern of concealment, it will take some time before the Agency is able to conclude that Iran's nuclear program is exclusively for peaceful purposes. ${ }^{\not 430}$ The IAEA report had significant impact in decelerating the militarization drift of the INP in the mid-2000s.

The second component of Iran's de-securitization campaign was even more unprecedented and unorthodox for the Islamic Republic of Iran. In early May 2003, the Iranian Government sent, through the Swiss Embassy in Tehran, a secret proposal to Washington, with the apparent blessing of Supreme Leader Ayatollah Khamenei. The comprehensive proposal's objective was to try and "test the waters for a 'grand bargain' with Washington, a rapprochement along the lines of Nixon's China strategy." The stepby-step proposal's long-term goal was to deescalate Iran-U.S. relations from one of ideologically driven, wholesale animosity to a realistic negotiation compartmentalized into manageable wish and woe lists. The Iranians believed that such a problem-solving approach would pave the way for a breakthrough in the vicious circle of mutual exclusivity in defining national interests between Iran and the US and contribute to an atmospheric change where cooler heads on both sides could prevail. The Bush Administration, however, spurned the Iranian offer, apparently due to the premature triumphalism unleashed by the "Mission Accomplished" moment in Iraq. Even if it was no more than obliquely expressed, buried in Tehran's unofficial offer was an unprecedented readiness to disengage Iran's national security interests from its nuclear

\footnotetext{
${ }^{430}$ Implementation of the NPT Safeguards Agreement in the Islamic Republic of Iran Report by the Director. GOV/2003/75. November 10, 2003.

Generalwww.iaea.org/Publications/Documents/Board/2003/gov2003-75.pdf (Accessed June 16, 2010).
} 
program and forge a nuclear-free modus vivendi with the United States in the Middle East. $^{431}$

On a balanced reading, the Khatami administration's de-securitization campaign fell well short of making an enduring dent in what seemed to be turning into the INP's institutionalized securitization in the international system. One can hardly overstate the domestic political cost of the grand bargain's failure for President Khatami and his proWest reformist camp. As far as Iran's anti-West conservatives were concerned, the unreciprocated unclenching of fist by Khatami on Iran's nuclear program essentially vindicated Ayatollah Khamenei's long-held conviction that the INP was simply a tool of convenience opportunistically wielded by the United States to engineer regime change in Tehran.

In the meantime, Khatami's transparency policy with the IAEA was producing sub-optimal results under the mounting pressure applied by the United States. The June 17, 2004 report by the IAEA was especially strongly worded and lamented the fact that "Iran's cooperation has not been as full, timely, and proactive as it should have been." ${ }^{432}$ As the international institutional pressure on Iran was escalating, Tel Aviv and Washington were employing the language of kinetic force as an antidote to Tehran's seemingly recalcitrant nuclear behavior with more frequency and visibility. The IAEA was also coming under increasing pressure by Washington to refer Iran's nuclear dossier to the UN Security Council for the imposition of targeted sanctions under Chapter VII of

\footnotetext{
${ }^{431}$ Mohammad Homayounvash, Operation Odyssey Dawn and a Nuclear Instruction Undone; Tehran Bureau; http://www.pbs.org/wgbh/pages/frontline/tehranbureau/2011/04/opinion-operation-odyssey-dawnand-a-nuclear-instruction-undone.html

${ }^{432}$ The New York Times, June 17, 2004.
} 
the UN Charter, a scenario Iran was endeavoring to avoid at all cost without appearing intimidated.

In the meantime, the EU's role on the INP in this period was reduced to delaying the physical militarization of the nuclear faceoff between Tehran and Washington-Tel Aviv axis. IAEA Director General Mohamed Elbaradei later recalled a conversation between him, UK Foreign Secretary Jack Straw, and German Foreign Minister Joschka Fischer when the Europeans told him, "the EU-3 [the UK, Germany and France] was trying to act as a kind of 'human shield,' through their dialogue with Iran, to protect against the risk of military action by the United States or Israel." ${ }^{, 43}$

\section{Ahmadinejad's Nuclear Obsession}

In mid 2005, as the Bush Administration's WMD rationale for the Iraq war was proving nothing more than a deliberate subterfuge for regime change, the "Coalition of the Willing" was showing all symptoms of breaking apart, the post-invasion Iraq was turning into a full-blown military and diplomatic quagmire for the United States, and Iran's encirclement fears were dissipating, President Khatami's seemingly lenient posture toward the West on the INP came under scathing criticism in Iran's conservative power corridors. The cumulative result of these determinants was a presidential campaign run by the conservatives on the nuclear self-determination platform.

As part of this strategy, a perennial theme in presidential-hopeful Mahmoud Ahmadinejad's numerous stump speeches during his 2005-election campaign was to castigate the reformists' unreciprocated pandering to the West on the INP. After a firebrand Ahmadinejad assumed Iran's presidency in 2005, Tehran's nuclear attitude

\footnotetext{
${ }^{433}$ Mohamed Elbaradaei, The Age of Deception: Nuclear Diplomacy in Treacherous Times (New York, NY: Metropolitan Books, 2011).
} 
entered an era of nuclear flamboyancy and saber rattling, a drastic departure from President Khatami's period when Tehran was meticulously endeavoring to avoid being relegated into an international outcast. Having made the reformists' allegedly fainthearted nuclear policy into something of a campaign manifesto, the new President found himself with no choice but to allow nuclear brandishing brand and govern his foreign policy as well.

Veteran political observers inside and outside Iran were offering different narratives on who the new President's nuclear exhibitionism was and what to make of the reckless and provocative rhetoric coming out of Tehran nearly three decades into what was generally perceived to be a maturing Revolution. Whatever the private reasoning behind this strategy, one can hardly overstate the securitizing implications of such nuclear flamboyancy for the Islamic Republic in the Ahmadinejad era.

President Ahmadinejad's facilitating role in accelerating the drift of the INP toward the militarization extreme was not limited to his nuclear revisionism though. A few months into his new post, the President touched off an international outcry against Iran by advocating the elimination of the state of Israel "off the map" and calling into question the existence of the Holocaust in October and November 2005, respectively. Following these perplexingly unorthodox remarks, even for Iran's rather unwonted domestic political scene, the notion of "nuclear holocaust" figured with credibility in the international discourse on the INP. The net result was an unprecedented mobilization at the international level behind the designation of Iran's nuclear program as an imminent international threat. 
Within this context, the President's inflammatory rhetoric simply conferred credibility on the Israeli argument that an Iranian nuclear capability was not simply an existential threat to the Jewish state, rather it constituted an international challenge that called for the full energy of the international community. Ahmadinejad's rhetoric also tremendously granted Tel Aviv and Washington the luxury of sustaining and mainstreaming the language of kinetic action against Iran in absence of any "smoking gun” evidence on the existence of a nuclear weapons program in Iran.

\section{Iran's IAEA and UNSC Dilemma}

While Ahmadinejad's harsh and anachronistic rhetoric was helping galvanize global public opinion against Iran's nuclear effort, international institutional securitization of the INP was facing decreasing obstacles. At this point, the EU, for all practical purposes, had lost almost all credibility with the Iranians to hold in check, let alone reverse, the energized momentum of the INP toward militarization. Europe's debilitated status became even more evident in August 2005 when its highly publicized incentives package (aimed at perpetuating Iran's suspension of indigenous enrichment activities) was deemed by Tehran smacking of the Old Continent's colonial legacy. As a matter of fact, Tehran found the EU proposal so "insulting in its language and paltry in its benefits" $" 434$ that it actually incentivized Iran to terminate its suspension of uranium conversion activities at the ENTEC in Isfahan.

The IAEA Board of Governors' reaction to Iran's decision was to up the ante in its September 24, 2005 report by claiming “Iran's many failures and breaches of its obligations to comply with its NPT Safeguards Agreement constitute non compliance in

\footnotetext{
${ }^{434}$ Mohamed Elbaradaei, The Age of Deception: Nuclear Diplomacy in Treacherous Times (New York, NY: Metropolitan Books, 2011).
} 
the context of Article XII.C of the Agency's Statute." ${ }^{435}$ The trigger word "noncompliance" in the report paved the way for Iran's referral to the United Nations Security Council and officially marked the end of an era of appeasement in Iran's nuclear policy. From then on, Iran and the United States-Israel axis were engaged in a delicate game of chicken while Europe was standing idly by.

Iran shot back to the Board decision by announcing, on January 3, 2006 its intention to resume its uranium enrichment Research and Development activities at the Natanz pilot facility. The result of this upwardly spiraling chain of events was a nonunanimous decision by IAEA Board on February 4, 2006 to refer Iran's nuclear file to the UNSC. Tehran, determined not to appear buckling under pressure, retaliated by scaling back its policy of détente with the IAEA even further. On February 14, 2006 Tehran announced its suspension of implementing the Additional Protocol. Tehran's referral to the UNSC gave even more credibility to speculations, already in wide international circulation, that the United States was pursuing a carefully cultivated policy of "courting failure" on the INP to set the stage for taking kinetic action against the Iranian regime and, with any luck, decapitate it.

Washington's obstinate position that Iran suspend all enrichment activities as a precondition for negotiating with Tehran to start and the Bush Administration's unreasonable insistence on Iran scuttling the entirety of its pilot-scale uranium enrichment R\&D activities were vivid manifestation of this bellicose posture. In the words of the IAEA Director General, “"not one centrifuge' had taken on vast importance for those Beltway ideologues who saw the United States as a global disciplinarian and

\footnotetext{
${ }^{435}$ IAEA Board of Governors Report, Implementation of the NPT Safeguards Agreement in the Islamic Republic of Iran Resolution, September 24, 2005. www.iaea.org/Publications/Documents/Board/2005/gov2005-77.pdf (Accessed August 14, 2011).
} 
who listened only to one another, perpetuating beliefs that were utterly removed from reality. ${ }^{436}$

With no easing of Washington's humiliating prerequisites to talk to Tehran in sight, the E-3 took another shot at wooing Tehran back onto a diplomatic track. This time around, the E-3 initiative, enjoying the support of the five UNSC permanent members (P5), consisted of a fairly intriguing incentives package that would address a good chunk of Tehran's nuclear demands short of indigenous enrichment and reprocessing. Just as expected, however, the proposal had an infinitesimal chance to succeed in the face of formidable securitizing forces pounding on the INP and symbolized by the phrase "all options are on the table," as President Bush was fond of repeating. Under such stifling circumstances, Tehran was not even given enough time (Tehran wanted until August 22, 2006 to mull over the details) to formally submit its final response.

On July 31, 2006 the UNSC adopted Resolution 1696 under Chapter VII of the UN Charter demanding Iran suspend its uranium enrichment activities and work out its outstanding issues with the IAEA. Reference to Article 41 of Chapter VII in the resolution sent an unmistakable message to Tehran: the INP had been catapulted to an international security threat, the international institutional process on addressing the INP was more political than legal-technical, and the IAEA's de-securitizing capacity was drastically curtailed.

The head of the IAEA later put the irreversible impact of UNSC Resolution 1696 in most illuminating terms: "In my view, Security Council Resolution 1696 was not only counterproductive from a policy perspective, but also a misuse of the council's authority

\footnotetext{
${ }^{436}$ Mohamed Elbaradaei, The Age of Deception: Nuclear Diplomacy in Treacherous Times (New York, NY: Metropolitan Books, 2011).
} 
under Chapter VII of the UN Charter. It was staggering to compare the difference in treatment of North Korea and Iran. North Korea had walked out of the NPT and made explicit threats about developing nuclear weapons, yet the Americans were ready to join them in a direct dialogue... By contrast, Iran... was penalized for possibly having future intentions to develop nuclear weapons..."437

Under such hyper-securitized conditions, rendered more complex with the Israelis beating the drum for an imminent military strike unless the UN sanctions regime on Iran kept tightening and expanding and Iran's Arab periphery secretly imploring Washington to "cut off the head of the snake" by striking $\operatorname{Iran}^{438}$, the IAEA and EU-3's diplomatic dexterity hit insurmountable roadblocks and yielded no breakthroughs. Shortly thereafter, on December 3, 2006 the UNSC adopted Resolution 1737 under Article 41, Chapter VII of the UN Charter introducing a fresh set of sanctions against private and legal entities involved in Iran's "proliferation sensitive" activities. These punitive measures were intensified and expanded on March 24, 2007 with UNSC Resolution 1747.

In the meantime, the INP had picked up enough securitization energy to move forward on its own momentum. Now, talk of military attack on Iran was well on its way to become a mainstream issue in the U.S. foreign policy discourse on Iran. The increasing frequency with which President Bush, Secretary Rice, and Vice President Cheney, among others, utilized the code word for a conventional or, for that matter, nuclear war against Iran, "all options are on the table," was testimony to this atmosphere.

\footnotetext{
${ }^{437}$ Mohamed Elbaradaei, The Age of Deception: Nuclear Diplomacy in Treacherous Times (New York, NY: Metropolitan Books, 2011).

${ }^{438}$ King Abdullah of Saudi Arabia used the phrase. See, The New York Times, November 28, 2010.
} 
As all the de-securitizing actors of the INP seemed utterly exhausted and on the defensive, the U.S. intelligence community put a pause on the galloping pace of the INP toward a military conflict. On December 3, 2007 President Bush authorized, with delay and reluctance, the release of a declassified version of the NIE drafted in November 2007 and entitled: Iran: Nuclear Intentions and Capabilities. The NIE, "the Intelligence Community's (IC) most authoritative written judgments on national security issues designed to help US civilian and military leaders develop policies to protect US national security interests," was unmistakably emphatic in its key "high confidence" judgment that "in fall 2003, Tehran halted its nuclear weapons program."

The release of this document threw into sharp relief the reality gap in the mainstream American and international discourse on the INP where Tehran's determination to weaponize its nuclear capability had turned into something of an article of faith. NIE 2007 was a seminal document on several fronts. First, its counterintuitive key judgment indicated the intelligence community's success in de-politicizing its intelligence judgments following the Iraq fiasco and restoring its credibility and objectivity. Second, it's judgment that Iran had halted its weaponization activities in 2003 vindicated the hardheaded foreign policy realists who had long insisted Iran's alleged nuclear weapons program was directed against the Baath regime in Iraq and not Israel. Third, the timing of Iran's cessation of nuclear weapons activities, following the toppling of Saddam's regime in 2003, demonstrated that Iran's nuclear behavior was rational and prone to cost-benefit calculations. Naturally, this meant that Iran was a deterrable actor even in a nuclear context.

\footnotetext{
${ }^{439}$ National Intelligence Estimate, November 2007. Iran: Nuclear Intentions and Capabilities http://www.dni.gov/press_releases/20071203 release.pdf (Accessed December 12, 2011).
} 
Just as expected, realizing the long-term implications of NIE 2007 in demilitarizing the political discourse about Iran in Washington, the securitizing agents and actors of the INP quickly sprang into action questioning the credibility of the coordinated judgment of the 16 U.S. intelligence agencies. Peter Hoekstra, a Republican congressman and the former chairman of the House Intelligence Committee called the 2007 NIE "a piece of trash." A livid President Bush later termed the document as "eye-popping," lamenting its deleterious impact on the securitizing "momentum" of the INP. ${ }^{440}$ The neoconservatives in the Bush Administration were mainly concerned that the report would undo the accumulation of pressure on Iran, would inject second thoughts into the international community's judgments on the credibility of the U.S. President's proliferation judgments and threat perceptions, and would make the consensus building process to tighten the noose on the Iranian regimes more arduous.

The public venting of anger over the results of the NIE 2007, was arguably the most vivid manifestation of the widening gap between clinical intelligence on the INP and the expectations of the politicians in charge. In the meantime, as far as the Islamic Republic was concerned, the NIE's confirmation of Iran's suspension of its nuclear weapons program, its delayed and reluctant publication by the Bush administration, and a lack of visible change in Washington's rhetoric vis-à-vis Tehran following its release were all signs that the nuclear was simply a pretextual issue and the securitization of the INP had nonfactual underpinnings.

A most visible sign the securitization of the INP had grown fact-resistant was the adoption, on March 3, 2008 of yet another UNSC Resolution (1803) under Article 41 of the UN Charter extending and escalating the previous rounds of punitive measures. This

\footnotetext{
${ }^{440}$ George W. Bush, Decision Points (New York, NY: Crown Publishers, 2010).
} 
was followed, on September 27, 2008 by UNSC Resolution 1835 that further expanded the scope of entities subjected to UN sanctions and tasked Iran with proving "the exclusively peaceful nature of " its nuclear program to the international community if it wanted to "be treated in the same manner as that of any Non-Nuclear Weapon." The speedy adoption of these resolutions helped solidify the notion in Tehran that the UNSC was completely devoid of any de-securitizing agency when it came to dealing with the INP as it was hopelessly politicized.

Iran, having given up all hope on institutional international mechanisms to prevent the militarization of its nuclear enterprise à la Iraq, was testing the waters to turn to the United States directly. However, as this approach was being worked out, there appeared a fundamental and growing gap on the nuclear issue, at both diagnosis and remedy levels, between the Supreme Leader and President Ahmadinejad. This discrepancy essentially boiled down to the fact that whereas president Ahmadinejad viewed the nuclear dispute as inextricably intertwined with the broader context and legacy of Iran-US relations, the Supreme Leader favored viewing those as two separable, if not already discrete, issues. From Khamenei's perspective, the nuclear crisis was a marginal issue that was only incidental to Iran's hardcore grievances with the West. One can analyze President Ahmadinejad's persistent attempts to forge a rapprochement with Washington, despite never enjoying the Supreme Leader's public blessing, during both Bush and Obama administrations within this context. Under the prevailing conditions, President Ahmadinejad's multiple efforts at incorporating the nuclear issue into part of a package security deal with the United States did not succeed as they never received the 
Supreme Leader's definitive green light and as the Bush Administration was approaching the end of its lame-duck year in office.

\section{INP's Covert Militarization and Domestic De-Nationalization}

The election of President Barak Obama injected a guarded sense of optimism into Iran's leadership on the prospects for a de-militarized Iranian relationship with the United States and to resolve the INP standoff. Viewed from Tehran, President Obama's Iran policy seemed one of impressing on the Iranians that the Unites States was willing to drop the language of regime change, cultivate a strategic sub-nuclear modus vivendi with them, and find, through aggressive direct diplomacy, a non-coercive solution for the INP. More importantly, the Iranians publicly appreciated the fact that the new President was deliberately distancing the U.S. from the maximalist "suspension before negotiation" position of the Bush Administration. That position had struck the Iranians as a sinister

plot to lend more international credence to and cloak the underlying strategy of "regime change" by Washington.

President Obama's INP policy got off to a lethargic start, however, as the task of cleaning up after his predecessor's twin wars in Iraq and Afghanistan coupled with the financial meltdown on the home front and severe global economic recession consumed much of the President's attention. Another factor in this regard was the unchanged status of the NIE 2007's key judgments and intelligence reports that Iran's commercial-scale enrichment operations at Natanz had hit technical snags. As a result, Gregory Schulte, the U.S. Ambassador to the International Atomic Energy Agency under Bush, stayed in his position well into Obama's first year as president until June 2009. 
As the new Administration was getting ready to put into action its more pragmatic Iran policy by directly engaging the top Iranian leadership (Obama sent a letter directly to the Supreme Leader Ayatollah Khamenei), Iran's domestic political scene went through a tumultuous transformation. In June 2009, a botched up presidential election significantly eroded the united front Tehran had been strenuously trying to put up vis-à-vis the international scene. Following the post-election upheavals, Mir Hossein Mousavi, the one-time Prime Minister and presidential hopeful emerged, for the first time in Iran's nuclear history, as a domestic opposition figure who had the capacity to challenge and undo the state's nuclear judgments and decisions with long-term consequentiality. The fact that the Green Movement leader's nuclear attitude was more hawkish than that of the incumbent firebrand Ahmadinejad, in some experts' view, warranted caution in lending unqualified support to Mousavi, whose name received mention in the U.S. intelligence community's memoranda as one of the founding fathers of the post Revolution INP.

Following the election crisis, the Ahmadinejad Administration, with its domestic legitimacy compromised and his image deeply scarred, was scrambling to score a substantial foreign policy victory to reassert its credentials. This led to Iran's surprisingly lenient posture on the nuclear issue in 2009 when Tehran agreed in October to ship a whopping 75 percent of the $4000 \mathrm{lbs}$ LEU in its possession to Russia and France to be converted into $20 \%$ enriched fuel plates Iran needed for the Tehran Nuclear Research Reactor. ${ }^{441}$ Faced with Mousavi's blistering criticism of the deal as "squandering away" Iran's nuclear gains, a humbled Ahmadinejad backed out of the agreement and publicly

\footnotetext{
${ }^{441}$ LaFranchi, Howard. 2009. Iran nuclear talks: Will fuel swap be finalized? The Christian Science Monitor, Oct 19, 2009. http://search.proquest.com/docview/405573600?accountid=10901 (accessed April 19, 2011).
} 
accused Mousavi of throwing a monkey wrench into the government's foreign policy decisions.

In this period, one could see the embryonic signs of the de-nationalization of the INP following the election crisis where the nationally electrifying effect of nuclear program seemed teetering on the brink of dissipation. The opposition "Green Movement" that grew out of Mousavi's ill-fated presidential bid even came close to presenting a domestic securitization challenge to Iran's nuclear program with some self-appointed prominent Green figures referring to the INP as an anti-democratic enterprise being imposed on the Iranian people by an authoritarian regime. This securitizing move, however, fizzled out rather quickly in no small part thanks to Mousavi's hawkish stance on the nuclear swap deal.

Following the election fallout, Ahmadinejad's nuclear obsession also came under mounting pressure by the right-wing traditional principlists (osoolgarayan-e sonnat-i) who took the president to task for reducing the Iranian Revolution and the political system that came out of it to the nuclear standoff with the West. Their argument was that Iran's recognition (as a regional power) should be premised upon the more fundamental and durable virtues the Iranian Revolution stood for, (like justice, freedom, and selfdetermination) rather than being consumed, contaminated, and exhausted by some nuclear saber rattling with the West.

In the meantime, further complicating nuclear deal-making with Iran following the 2009 elections was the highly dynamic state of affairs in Tehran and the President's substantially emasculated credentials, dubious legitimacy, and uncertain hold on power. Now the question was whether Ahmadinejad could still be treated as an authoritative 
interlocutor on Iran's nuclear program. The fallout from the 2009 elections and the overwhelming pressure applied to the Obama White House by the U.S. Congress and domestic public opinion to put America on the right side of history and side with the opposition Green Movement essentially meant that Obama's pragmatism was dead on arrival. This situation left the President with no choice but to follow in the footsteps of his predecessor. At about the same time, a deluge of reports started leaking to the mainstream media that the U.S. and Israeli intelligence agencies had furnished the IAEA with incriminating evidence alleging Iran had conducted recent weaponization studies on its nuclear program. These reports further torpedoed any hope for charting an alternative path to deal the INP. The result was the continuation of the United States' broad strategy to put the INP on a securitized path at the international institutional and state levels.

A significant even further consolidated the Obama Administration's change of mind, if not heart, about the INP toward late 2009. In September 2009, Tehran revealed to the IAEA its almost completion of a secret enrichment facility, known as the Fordow Fuel Enrichment Plant (FFEP), buried some 265 underground near the city of Qom. Once fully operational, the facility's depth would, according to some estimates, put it beyond Israel's conventional bunker-busting capabilities to take it out. Fordow's proximity to the holy city of Qom would also make a nuclear operation against it look like a countervalue (city-busting) strike. The combination of these factors would essentially grant Iran the capability to deter by denial an Israeli attack on its nuclear facilities. From this point on, the language of "zone of immunity" entered the Israeli conversation on Iran's nuclear program, a moment when Iran's nuclear facilities would be physically shielded against a successful attack. 


\section{Iran-Turkey-Brazil Axis}

In May 2010, Iran launched its last offensive aimed at garnering much-needed foreign policy credibility for a legitimacy-deficient President Ahmadinejad and diffusing the mounting talk of an eventual strike by Israel with or without Washington's consent. Brzail, an emerging "diplomatic giant" with permanent membership aspirations at the UN and Turkey with a neo-Ottomanist paradigm shift toward the East under the stewardship of Prime Minister Erdogan became active interlocutors in Iran's nuclear dossier in 2010. The two countries, with discrete regional and international agendas, found the INP a once-in-a-blue-moon opportunity that comes medium-sized powers' way to punch above their actual weight.

Turkey, anxious to utilize its "strategic depth" as prescribed in the doctrine promulgated by political scientist turned Foreign Minister Ahmet Davutoglu, became especially active on Iran's nuclear conversation in 2010. As a matter of fact, Ankara's relations with Tehran became so cordial under Davutoglu that, for the first time since 1979, Turkey removed Iran from the list of strategic threat countries in the 2010 edition of Turkey's main national security document, the so-called Red Book. This development coupled with the addition of Israel to the "threat list" gave Ankara unique credentials - as a regional Muslim state- to sway Tehran's nuclear calculus toward a more conciliatory path.

Brazil complemented Turkey in diffusing the gathering storm on the INP. As a one-time nuclear defiant Brasilia had been on the receiving end of what it perceived was a discriminatory non-proliferation regime in the 1970s and 1980s before it finally came clean with its secret nuclear weapons program in the 1990s and acceded to the NPT in 
1998. As two-time Brazilian Foreign Minister Celso Amorim later recalled, this legacy enabled Brasilia to reflect on the INP and argue with Tehran from a position of sympathy. Particularly appealing to the Iranians was President Lula and FM Amorim's stance on the imperativeness of recognizing "Iran's right to develop her own peaceful nuclear program, including her capacity to enrich uranium" as "the missing link" in the West's approach to the INP.

From Amorim's perspective, such recognition would give Iran the much-needed assurance that it would not be indefinitely discriminated against because of its clandestine nuclear activities in the past if it adopted a full-disclosure policy going forward. Likening Iran's position to someone whose credit card had been suspended due to payment default, Amorim believed Iran's non-proliferation creditworthiness should not be "stripped forever" once it rectified its suspect past. In some pointed and charged remarks, bound to be music to Tehran's ears, he went on saying, "just as one should not be deprived of access to credit because of religion or race - or even because one lives in a "bad neighborhood' (the analogy holds) — a country cannot be deprived of access to a technology because it is Muslim or is situated in a dangerous region, especially if one of its neighbors is known to possess not only the same technology, but the actual weapons." ${ }^{442}$

Within this atmosphere of camaraderie, in the Tehran Declaration jointly issued by Turkey, Brazil, and Iran on May 17, 2010, the parties reaffirmed "the right" of the Tehran to all nuclear fuel cycle activities including uranium enrichment. Tehran, on the other hand, demonstrated unexpected flexibility to swap 1200 kilograms of its LEU in

${ }^{442}$ Celso Amorim, "Brazil and the Middle East ," The Cairo Review of Global Affairs, July 2011, http://www.aucegypt.edu/gapp/cairoreview/Pages/articleDetails.aspx?aid=64 (accessed July 30, 2011). 
exchange for 120 kilograms of $20 \%$ enriched plates required to fuel the Tehran Research Reactor. ${ }^{443}$ Arguably, the most significant aspect of the Declaration was Iran's consent to deposit more than fifty percent of its LEU in Turkey in one tranche, a significant departure from its earlier rejection to transfer its LEU stockpile to foreign territory. This agreement, however, failed to make much de-securitizing dent in the INP as the Obama Administration refused to endorse its provisions and chose, instead, to forge ahead with a new and escalating set of punitive measures against Iran. As ElBaradi later wrote in his memoires, Washington's nonchalant dismissal of the Tehran Declaration was yet another sign, "The West refused to take yes for an answer.",444

\section{INP Enters Kinetic Militarization Zone}

With the INP deeply ensconced in the military extreme of the securitization spectrum, Iran's nuclear program came under a host of unconventional attacks. The general perception in Washington and Tel Aviv was that if the program couldn't be knocked off its feet, it could at least be knocked off its stride while more comprehensive solution were being conceptualized. The subversive measures that included, among other things, cyber warfare (e.g. the Stuxnet virus attack), sabotage, and targeted assassination of Iranian nuclear scientists picked pace and became increasingly aggressive after mid2010. According to analysts, in absence of an attractive military option in the near term the United States and Israel had settled for the intensification of these "measure short of war" in 2010 to retard Iran's crossing of the proverbial "point of no return."

\footnotetext{
443 "Joint Declaration By Iran, Turkey, and Brazil," May 17, 2010, http://www.guardian.co.uk/world/julianborger-global-security-blog (accessed August 27, 2010).

${ }^{444}$ Mohamed Elbaradaei, The Age of Deception: Nuclear Diplomacy in Treacherous Times (New York, NY: Metropolitan Books, 2011).
} 
An alternative view, however, was that the cumulative impact of these unconventional measures-- along with an ever-stiffening sanctions regime and the singling out of Iran in the Obama Administration's Nuclear Posture Review (NPR) as the only non-nuclear weapons state subjected to a nuclear strike by the US-actually constituted a curtain-raiser to a full-blown military attack on Iran by modulating its shock value. This view was partially based on the Iraqi experience with the UN where successive resolutions demonstrated how quantity (11 UNSC resolutions) could turn into quality (the 2003 invasion). Whatever the private reason behind these covert measures, their accumulative impact demonstrated that the INP had already entered the kinetic extreme of militarization in 2010, only one step removed from an all-out military confrontation.

The INP also came under some domestic securitizing pressure in 2011 following the March 11 tsunami in Japan and the partial core meltdown at the Fukushima Daiichi Nuclear Power Plant. As the incident deeply stigmatized nuclear energy and cast a shadow over its future sustainability, the Iranian Majlis (Parliament) set up a blue ribbon committee whose official mandate was to investigate the delay in commissioning the BNPP, but which had a broader agenda: soul-searching on the issue of nuclear energy in Iran. In April 2011, Hassan Ghafouri Fard, a nuclear expert and chair of the investigative committee, in some unprecedented public remarks, called for mothballing the BNPP indefinitely as its high capital cost had rendered it uncompetitive compared to building a new plant from scratch.

In the meantime, the INP hyper-securitizers saw in the global nuclear abolitionist movement that grew out of the "Fukushima factor" yet another opportunity to question 
the expediency of the BNPP in a seismically active region in southwestern Iran. Lacking incontrovertible technical credibility, this securitizing move had a fleeting lifespan, though, as the BNPP went critical on May 8, 2011.

Furthermore, in 2011 the INP became the passive beneficiary of the Arab Spring as the democratic whirlwinds in the Middle East and North Africa pushed the Iranian nuclear program onto the backburner of the United States' strategic foreign policy priorities. The Arab Spring's de-securitizing energy, however, proved no match for the INP as Tehran's nuclear effort assumed newfound significance in late 2011. On November 8, 2011, in a report to the IAEA Board, Yukiya Amano, Director General of the International Atomic Energy Agency used the unverified intelligence provided by the United States and Israel, previously deemed of dubious authenticity by the IAEA under ElBaradaei, as incriminating evidence Iran was on a structured path to nuclear weaponization. The report claimed a range of activities carried out by Iran that were deemed "relevant to the development of a nuclear explosive device." These included "efforts... to procure nuclear related and dual use equipment and materials by military related individuals and entities; efforts to develop undeclared pathways for the production of nuclear material; the acquisition of nuclear weapons development information and documentation from a clandestine nuclear supply network; and work on the development of an indigenous design of a nuclear weapon including the testing of components. ${ }^{.445}$

The report, both in its letter and spirit, demonstrated how quickly the ElBaradaei legacy had grown undone and the extent to which the IAEA's judgments on Iran under the new Director General had fallen in line with the securitizing actors of the INP. The

\footnotetext{
${ }^{445}$ IAEA Report On Iran Nuclear Safeguards Sent to IAEA Board, November 8, 2011. www.iaea.org/Publications/Documents/Board/2011/gov2011-65.pdf (Accessed December 24, 2011).
} 
result was a candid outcry of accusations of duplicity, lack of credibility, and doublestandard from the INP's now sizable epistemic community. Arguably the most trenchant critique came from Robert Kelley, a nuclear engineer and the IAEA's chief weapons inspector in Iraq, who called the report "highly misleading" and accused the IAEA of having fallen victim to a "misinformation campaign" that was leading the international community "by the nose." For Kelly, "the way the data [had] been presented" in the November 2011 report produced "a sickly sense of déjà vu," reminiscent of the prelude to the 2003 Iraq War. ${ }^{446}$ The Amano report was also in direct contradiction with the latest U.S. National Intelligence Estimate 2010 on the INP that essentially repeated the key judgments of NIE 2007.

\footnotetext{
${ }^{446}$ Robert Kelly, Bloobmberg, January 10, 2012. Nuclear Arms Charge Against Iran Is No Slam Dunk: Robert Kelley. http://www.bloomberg.com/news/2012-01-11/iran-nuclear-weapons-charge-is-no-slamdunk-commentary-by-robert-kelley.html (Accessed January 18, 2012).
} 


\section{CHAPTER 7}

\section{CONCLUSION}

Over the span of some five decades since its inception, Iran's nuclear program is still far from full-fledged fruition. This has turned the INP into the most expensive and longest civilian nuclear program in the making in the world, the most politicized enterprise in Iran's history, and a development that has internationalized Iran's domestic scene like never before.

Panoramically viewed, the story of the Iranian nuclear program has been one of progressively moving on the securitization spectrum toward kinetic militarization. The opening salvo of the securitization trajectory of Iran's nuclear program could be traced back to May 1974 when India's Peaceful Nuclear Explosion triggered a fundamental change of heart in Washington on the Atoms for Peace Program's long-term sustainability, imbued indigenous nuclear enterprises with proliferation concerns, and cast doubt on the effectiveness and sufficiency of the international non-proliferation regime's safeguards to detect, much less deter, clandestine diversion of nuclear material from civilian nuclear facilities.

The coincidence of such a massive overhaul in proliferation thinking in Washington with the Shah's full-fledged nuclear bid marked the beginning of the designation of the INP as a proliferation concern. These U.S. concerns were only accentuated in the mid-1970s once set against the backdrop of the Monarch's rapid morphosis into a "national security leader", his high security expectations, and windfall petrodollars that made HIM's military and nuclear extravaganza financially feasible. 
As these generic factors were defining the broader contours of the securitization package of Iran's nuclear enterprise in the mid-1970s, Tehran's premature insistence on indigenously possessing the full nuclear fuel cycle further heightened Washington's proliferation concerns. The Shah's cavalier attitude toward Tehran's NPT commitments and his thinly disguised irritation at the existing international nuclear order (exemplified by Iran's outright indignation at its exclusion from The Nuclear Suppliers Group), only helped intensify Washington's apprehensions. Further fueling the securitization drift of the INP in the mid 1970s was a perceived lack of proportionality between Tehran's declared long-term civilian nuclear ambitions and the Iranian economy's absorptive capacity to actually utilize them.

On a balanced reading, an argument can be made that although the macro architecture of the international system, defined by the arch rivalry between the US and the USSR, exercised a dampening impact on the full-blown designation of the INP as a proliferation threat, the securitization drift of the INP started in the mid-1970s. After the Iranian Revolution of 1979, Iran's adoption of the policy of neither east nor west (na sharqi na qarbi) substantially removed this de-securitizing impediment at the systemic level and Iran's war born nuclear awakening during the Iran-Iraq War (1980-88) came under mounting securitization especially by the United States.

Over the years after the 1979, a revisionist Tehran's declared policy of exporting its revolution to the Middle East and, concomitant with it, Iran's ties to violent non-state actors in the Middle East set the stage for the contextualization of the INP within international terrorism. In the 1990s Iran's efforts to acquire ballistic missile technology and it's clandestine nuclear procurement activities on the black market further intensified 
the proliferation concerns of the United States and pushed Tehran deeper into the militarization extreme of the securitization spectrum. By the late 1990s, one could argue, the securitization of the INP was, by and large, institutionalized and a host of state, nonstate, and organizational actors were couching Tehran's nuclear efforts in proliferation terms. By the early 2000s, the securitization framework of the INP had grown so hegemonic that a technocrat President Rafsanjani and a reformist President Khatami's efforts to bring Iran back into the international fold proved no match for dismantling this template. In the early 1990s Iran's policy of throwing its weight behind derailing the Middle East peace process catapulted Israel onto the forefront of an internationalizing securitizing campaign vis-à-vis the INP.

Although Tehran's efforts at adopting a full-disclosure nuclear policy and its more generic détente policy toward the Middle East after the defeat of its archenemy Saddam Hussain in the 1990-1991 Persian Gulf War bore some moderate desecuritization fruits, the collapse of the Soviet Union in 1991 and the September 11 attacks of 2001, neutralized those gains and threw Iran back into the foreground of international proliferation concerns. Tehran's inclusion by the George Bush Administration in the so-called axis-of-evil was the most vivid manifestation of the INP's elevated placement in US national security anxieties. The presidency of Mahmoud Ahmadinejad in 2005 further consolidated this prioritization as the new president reversed Tehran's conciliatory posture toward the international non-proliferation regime, exemplified by Tehran's suspension of its enrichment activities as a confidence building measure. Ahmadinejad's unorthodox inflammatory rhetoric on Israel only helped intensify the securitization of the INP and its unprecedented galloping toward 
militarization in the late 2000s. Now the INP's securitization template had grown so powerful that even the U.S. intelligence community's consensus verdict (NIE 2007) that Iran had halted the weaponization component of its nuclear program did little to make a dent it.

With the first decade of the 2000s coming to a close, the securitization of the INP was progressively moving toward kinetic militarization. The most significant manifestation of this kinetic phase was the unfolding of a full-fledged covert warfare characterized by kidnapping and targeted assassination of Iranian nuclear scientists and a cyber warfare against Iran's nuclear facilities. The highly politicized IAEA's November 2011 report on Iran (long on speculative extrapolations and short on factual/physical judgments) and the subsequent ratcheting up of Israel's international pressure campaign that the INP was approaching the so-called "zone of immunity", where a conventional military strike would prove incapable of taking out Iran's nuclear facilities especially in the deep underground Fordow uranium enrichment site, is a most vivid indication of how perilously close the INP has come to being subjected to a massive military strike.

This ever expanding and deepening trend of the INP's securitization leads one to speculate that unless a comprehensive international de-securitization of the INP takes place (through regime change or a drastic change of heart in Tehran, both unlikely scenarios in the foreseeable future) the securitization juggernaut of Iran's nuclear program would erupt into a de-proliferating military operation on Tehran. 


\section{BIBLIOGRAPHY}

Abbott, John. The Iranians: how they live and work. David \& Charles, 1977.

Afkhami, Gholam R. The life and times of the Shah. Berkley: University of California Press, 2009.

Afrasiabi, Kaveh L. Iran's Nuclear Program: Debating Facts Versus Fiction. Book Surge Publishing, 2006.

Albright, David. "South Africa and the Affordable Bomb." Bulletin of the Atomic Scientists 50, no. 4 (July/August 1994).

Alexander L. George, Andrew Bennett. Case Studies and Theory Development in the Social Sciences. Cambridge, MA: The MIT Press, 2005.

Alidad Mafinezam, Aria Mehrabi. Iran and Its Place among Nations. Westport, connecticut: Praeger, 2007.

Allison, Graham. Nuclear Terrorism: The Ultimate Preventable Catastrophe. New York, NY: Holt Paperbacks, 2005.

Allison, Graham T., and Morton H. Halperin. "Bureaucratic Politics: A Paradigm and Some Policy Implications." World Politics, 24 (1972): 40-79.

Aminzade, Ronald. "Class Analysis, Politics, and French Labor History." In Rethinking Labor History, by L. Berlanstein. Urbana, Chicago: University of Illinois Press , 1993.

Amuzegar, Jahangir. "Iran's Economy and the US Sanctions." The Middle East Journal 51, no. 2 (Spring 1997): 185-99.

Anthony H. Cordesman, Martin Kleiber. Iran's Military Forces and Warfighting Capabilities: The Threat in the Northern Gulf. Westport, Connecticut : Praeger, 2007.

Ball, Deborah Yarsike. Russia's Strategic View: Diminished Threats and Diminished Capabilities. Memo, PONARS Policy Memo 28, Lawrence Livermore National Library, 1998.

Barbara Rogers, Zdenek Cervenka. The Nuclear Axis: Secret Collaboration Between West Germany and South Africa. New York, NY: Times Books, 1978.

Barry Buzan, Ole Waever. "Macrosecuritization and security constellations: reconsidering scale in securitization theory." Review of international Studies 35, no. 2 (2009).

—. Regions and Power. Cambridge: Cambridge University Press, 2003. 
Barry Buzan, Ole Waever, and Jaap de Wilde. Security: A New Framework for Analysis. Boulder, Colorado: Lynne Rienner Publishers, 1998.

Barry Buzan, Ole Waever, Jaap de Wilde. Security: A New Framework for Analysis . Boulder, CO: Lynne Rienner Publishers, 1998.

Bipartisan Policy Center. Meeting the Challenge U.S. Policy Toward Iranian Nuclear Development. Washington D.C.: Bipartisan Policy Center, 2008.

Bolton, John. Surrender Is Not an Option: Defending America at the United Nations. New York, NY: Threshold Editions, 2008.

Brzezinski, Zbigniew, Brent Scowcroft, and Richard Murphy. "Differentiated containment." Foreign Affairs 3, no. 76 (May/June 1997 1997): 20-30.

Burr, William. U.S.-Iran Nuclear Negotiations in 1970s Featured Shah's Nationalism and U.S. Weapons Worries. National Security Archive Electronic Briefing Book No. 268, 2009.

Bush, George W. Decision Points. New York, NY: Crown Publishers, 2010.

Buzan, Barry. "Will the 'global war on terrorism' be the new Cold War?" International Affairs 82, no. 6 (2006).

Cahn, Anne Hessing. "Determinants of the Nuclear Option: The Case of Iran ." In Nuclear Proliferation and the Near-Nuclear Countries, by Onkar Marwah and Ann Schulz. Cambridge, MA: Ballinger Publishing Company, 1975.

Chubin, Shahram. Iran's Nuclear Ambitions. Washington, D.C.: Carnegie Endowment for International Peace, 2006.

Cirincione, Joseph. Bomb Scare: The History and Future of Nuclear Weapons. February 22, 2007. http://mitworld.mit.edu/video/445 (accessed September 15, 2010).

-. Bomb Scare: The History and Future of Nuclear Weapons. New York: Colombia University Press, 2007.

Clawson, Henry D. Sokolski and Patrick, ed. Checking Iran's Nuclear Ambitions. Carlisle, PA,: U.S. Army War College, 2004, 2004.

Clawson, Patrick. "Ambitious Iran, Troubled Neighbors." Foreign Affairs (Council on Foreign Relations) 72, no. 1 (1992): 124-142.

Cockcroft, John. "The Baghdad Pact Nuclear Training Centre." Nature 179, no. 4567 (5 1957): 936. 
Cohen, Avner. Israel and the Bomb. New York, NY: Columbia University Press, 1999.

Commons, Great Britain. Parliament. House of. Parliamentary papers, Volume 9. HMSO, 1960.

Commons, Great Britain. Parliament. House of. Parliamentary papers, Volume 9. HMSO, 1959.

Control, National Academy of Sciences (U.S.). Committee on International Security and Arms. Nuclear Arms Control: Background and Issus. Washington, D.C. : Committee on International Security and Arms Control and National Academy of Science, 1985.

Cordesman, Anthony H. Iran's Developing Military Capabilities. Washington D.C.: Center for Strategic \& International Studies, 2005.

Daniel Byman, Shahram Chubin, Anoushiravan Ehteshami, Jerrold Green. Iran's Security Policy in the Post-revolutionary Era. RAND, 2001.

David Cortright, Amitabh Mattoo. "Indian Public Opinion and Nuclear Weapons Policy ." In India and the Bomb: Public Opinion and Nuclear Options, by Amitabh Mattoo David Cortright, edited by David Cortrigh and, 3-22. Notre Dame, Indiana : University of Notre Dame Press , 1996.

Delpech, Therese. Iran and the Bomb: The Abdication of International Responsibility . New York: Columbia University Press, 2007.

E.H.Carr. The Twenty Years' Crisis 1919-1939: An Introduction to the Study of International Relations . Edited by Michael Cox. New York, NY: Palgrave Macmillan, 2001.

Ehteshami, Anoushiravan. After Khomeini: the Iranian Second Republic. London, New York: Routledge, 1995.

Eisenstadt, Michael. "Living with a Nuclear Iran?" Survival: Global Politics and Strategy 41, no. 3 (1999): $124-148$.

Elbaradaei, Mohamed. The Age of Deception: Nuclear Diplomacy in Treacherous Times. New York, NY: Metropolitan Books, 2011.

"Energy Agreement Inked." Washington Morning Star, February 1974: 6.

Erlich, Reese. The Iran Agenda: the Real Story of U.S. Policy and the Middle East Crisis. Polipoint Press, 2007. 
Etemad, Akbar. Barnameh-ye enerji-ye atomi-ye iran, talash-ha va tanesh-haa (Iran's Nuclear Energy Program, Hopes and Challenges). Edited by Gholam Reza Afkhami. Bethesda, MD: Bonyad-e Motale'at-e Iran (Foundation for Iranisn Studies), 1997.

Etemad, Akbar, interview by Enayat Fani. "Gharb Dorough Migooyad, Iran Bayad Hastei Shavad (The West is Lying, Iran Should Go Nuclear)."

http://www.bbc.co.uk/persian/iran/2009/11/091101_ag_be_ebarate_digar_etemad.shtml. BBC, (November 1, 2009).

Etemad, Akbar, interview by Sergei Barseghian. Nagofteh-haye Akbar Etemad, Pishgame Fan Avari'ye Hastei Iran (The Untold Story of Akbar Etemad, The Pioneer of Iran's Nuclear Technology) Etemad Melli, ( April 9, 2008).

Etemad, Akbar. "Nuclear Energy: A Challenge for Industrializing Countries ." In Global Energy Assessment and Outlook, by A. Perlmutter, L. Scott B.N. Kursunoglu. Routledge, 1984.

Fathollah-Nejad, Ali. Iran in the Eye of Storm: Backgrounds of a Global Crisis.

Germany: Peace \& Conflict Studies, Institute of Sociology, University of Münster , 2007.

Fayazmanesh, Sasan. The United States and Iran: Sanctions, Wars and the Policy of Dual Containment. Routledge, 2008.

Feuilherade, Peter. "Iran: Nuclear Conundrum." The Middle Esat 1, no. 236 (July 1994).

Gall, Norman. "Atoms for Brazil, Dangers for All ." Bulletin of the Atomic Scientists, June 1976.

Giles, Gregory. "The Islamic Republic of Iran and Nuclear, Biological, and Chemical Weapons." In Planning the Unthinkable: How New Powers Will Use Nuclear, Biological, and Chemical Weapons, edited by Scott Douglas Sagan, James J. Wirtz Peter R. Lavoy. Ithaca, New York: Cornell University Press, 2000.

Goldstein, Avery. "Robust and Affordable Security: Some Lessons from the SecondRanking Powers during the Cold War ." Journal of Strategic Studies, 15, no. 4 (1992): $476-527$.

Gregersen, Niels Henrik. "Risk and Religious Certainty: Conflict or Coalition?" Argang 8, no. 1 (2004): 22-32.

Harry Schwartz, Deputy Assistant Secretary for Near East and South Asian Affairs Department of Defense. Secret, November 4, 1968.

Hashmi, Sohail H. "Islamic Ethics and Weapons of Mass Destruction An Argument for Nonproliferation." In Ethics and Weapons of Mass Destruction: Religious and Secular 
Perspectives (The Ethikon Series in Comparative Ethics), 322. Cambridge : Cambridge University Press, 2004.

"Hassan Toufanian. Interview recorded by Zia Sedghi, 9 May, 18 \& 19 July 1985, Washington, District of Columbia. Iranian Oral History Collection, Harvard University." Middle Eastern Division, Widener Library, Harvard College Library. 9 May, 18 \& 19 July 1985. http://nrs.harvard.edu/urn-3:FHCL:628390 (accessed March 10, 2011).

Hemmer, Christopher. " Responding to a Nuclear Iran." Parameters: US Army War College; 37, no. 3 (2007): 42-53.

Henry Sokolski, Patrick Clawson. Getting Ready for a Nuclear-Ready Iran. Strategic Studies Institute U. S. Army War College, 2005.

Herman Franssen, Elaine Morton. "A Review Of US Unilateral Sanctions Against Iran." The Middle Esat Economic Survey, August 26, 2002.

Hudson, Valerie. Foreign Policy Analysis: Classic and Contemporary Theory. Lanham, Maryland: Rowman \& Littlefield Publishers, 2006.

Hymans, Jacques E. C. The Psychology of Nuclear Proliferation: Identity, Emotions and Foreign Policy. Cambridge: Cambridge University Press, 2006.

Jervis, Robert. Perception and Misperception in International Politics. Princeton, NJ: Princeton University Press, 1976.

Kam, Ephraim. A Nuclear Iran: What Does it Mean, and What Can be Done. Memorandum, Tel Aviv: Institute for National Strategic Studies, 2007.

Kargon, Stuart W. Leslie and Robert. "Exporting MIT: Science, Technology, and NationBuilding in India and Iran." OSIRIS 21, no. 1 (2006): 110-130.

Karimi, Erfan. Barresi Syast-haye Dogane-ye Hasteh-i Amrika dar Iran Qabl va Pas az Enqelab (A Review of the United States' Double-standard Nuclear Policy toward Iran Before and After the Revolution. April 10, 2010. http://strategicreview.org/?p=14096 (accessed July 25, 2010).

Katzman, Kenneth. The Iran-Libya Sanctions Act (ILSA). CRS Report for Congress, 2006.

Khamenei, Ayatollah Ali. "Bayanat dar Haram-e Motahhar-e Razavi dar Aghaz-e Sal-e Navad (Speech in Imam Reza Shrine in Mashad) ." The Center for Preserving and Publishing the Works of Grand Ayatollah Sayyid Ali Khamenei . March 21, 2011. http://farsi.khamenei.ir/speech-content?id=11804 (accessed March 22, 2011). 
Killgore, Andrew I. "Israeli-Inspired U.S. Pressure May Backfire in Iran." The Washington Report on Middle East Affairs 3, no. XIV (September 1995).

Kissinger, Henry. "National Security Study Memorandum 219." March 14, 1975. http://www.fordlibrarymuseum.gov/library/document/nsdmnssm/nssm219a.htm (accessed September 20, 2010).

—. "The World Affairs Council National Conference on Islam and the West." Philadelphia, PA: World Affairs Council of Philadelphia, May 2005.

Kissinger, Hnery. "National Security decision Memorandum 292 ." April 22, 1975. http://www.ford.utexas.edu/library/document/nsdmnssm/nsdm292a.htm (accessed September 20, 2010).

Kroenig, Matthew. Exporting the Bomb: Technology Transfer and the Spread of Nuclear Weapons . Ithaca, NY: Cornell University Press, 2010.

Lake, Anthony. "Confronting Backlash States ." Foreign Affairs 2, no. 73 (March/April 1994).

Lavoy, Peter R. "Nuclear Myths and the Causes of Nuclear Proliferation." Security Studies 2, no. 3, 4 (September 1993): 210.

Ledeen, Michael A. The Iranian Time Bomb: The Mullah Zealots' Quest for Destruction. Truman Talley Books, 2007.

Lubrani, Uri, interview by Yoni Kimpinski. "Attack on Iran Last Resort for Israel" Israel National News. March 21, 2010.

Mahvi, Abolfath. 40-year-old dream How Iran's nuclear program was born . January 6, 2009. http://www.iranian.com/main/2009/jan/40-year-old-dream (accessed July 14, 2010).

Matlabi, Masood. "Enqelab-e Eslami va Chalesh-e Hasteh-ye Iran (The Islamic Republic and Iran's Nuclear Crisis)." Aftab . July 10, 2007.

Mayer, Charles C. "National Security to Nationalist Myth: Why Iran Wants. Nuclear Weapons." Thesis. Naval Postgraduate School, 2004.

McKay, H. A. C. "The Cento Institute of Nuclear Science in Tehran." Nature 186, no. 4724 (1960): 513-515.

Mearsheimer, John J. " Why We Will Soon Miss The Cold War ." The Atlantic Monthly 266, no. 2 (August 1990): 35-50 .

Mearsheimer, John J. "Reckless States and Realism." International Relations 23, no. 2 (2009): 241-256. 
Medeiros, Evan. Reluctant Restraint: The Evolution of China's Nonproliferation Policies and Practices, 1980-2004 (Studies in Asian Security). Stanford University Press, 2007.

Mohiaddin Messbahi, "Free and Confined: Iran and the International System," Iranian Review of Foreign Affairs 2, no. 5 (Spring 2011): 29-34.

Mohiaddin Messbahi, "Iran and Central Asia: Paradigm and Policy," Central Asian Survey 23, no. 2 (2004): 109-139.

Mohiaddin Mesbahi, "Eurasia between Russia, Turkey and Iran," in Key Players and Regional Dynamics in Eurasia The Return of the 'Great Game', 164-192 (London: Palgrave Macmillan, 2010).

Meyer, Stephen M. The Dynamics of Nuclear Proliferation. Chicago: University Of Chicago Press, 1984.

Milani, Abbas. Eminent Persians: The Men and Women Who Made Modern Iran, 19411979. Syracuse, NY: Syracuse University Press, 2008.

Milani, Mohsen. The Making of Iran's Islamic Revolution: from Monarchy to Islamic Republic. 2 . Westview Press, 1994.

Mossavar-Rahmani, Bijan. "Iran's Nuclear Power Programme Revisited." Energy Policy 8, no. 3 (September 1980): 189-202.

Mousavia, Hossein. Iran's Nuclear Diplomacy and the Roadmap to Weather the Crisis (Diplomasi-ye Hasteh-iye Iran va Naqsheh-ye Rah baraye Halle Bohran). February 25, 2011. http://www.ilna.ir/newsText.aspx?id=182017 (accessed May 14, 2011).

Mousavian, Seyyed Hossein. Iran-Europe Relations: Challenges and Opportunities . New York, NY: Routledge, 2008.

-. Protokole Elhaghi va Rahborde Jomhourye Eslamye Iran (The Additional Protocol and The Islamic Republic of Iran's Strategy)). Tehran: Expediency Council Strategic Research Center, 2007.

Mowatt-Larssen, Rolf. "Islam and the Bomb Religious Justification For and Against Nuclear Weapons." Belfer Center for Science and International Affairs . January 2011.

New Scientist . "Political Upheavals hit Iran's Nuclear Program ." November 30, 1978: 667.

Nye, Joseph. Power in the Global Information Age: From Realism to Globalization. New York, NY : Routledge, 2004. 
Parsi, Trita. Treacherous Alliance: The Secret Dealings of Israel, Iran, and the United States . Yale University Press, 2007.

Perkovich, George. "Dealing With Iran's Nuclear Challenge." (Carnegie Endowment for International Peace) April 2003: 4.

Phillips, James. "The Saddamization of Iran." Policy Review, no. 69 (Summer 1994).

Pikaev, Alexander. Nuclear Doctrines and Strategies. Edited by Alexander Nikitin, Sergey Oznobishchev Mark Fitzpatrick. Amsterdam: IOS Press, 2008.

Podhoretz, Norman. World War IV: The Long Struggle Against Islamofascism. New York, NY: Doubleday, 2007.

—. World War IV: The Long Struggle Against Islamofascism. New York: Doubleday, 2007.

Quester, George H. "The Shah and the Bomb." Policy Sciences 8, no. 1 (March 1977): 21-32.

Quinlan, Michael. Thinking About Nuclear Weapons Principles, Problems, Prospects. Oxford: Oxford University Press, 2009.

Rafsanjani, President Hashemi, interview by Mike Wallace. 60 Minutes (March 8, 1997).

Ramazani, Rouhollah K. The United States and Iran: The Patterns of Influence. New York, NY: Praeger Publishers, 1982.

-. The United States and Iran: The Patterns of Influence. New York, NY: Praeger, 1982.

Ramberg, Bennett. Nuclear Power Plants as Weapons for the Enemy: An Unrecognized Military Peril. Berkeley, CA: University of California Press, 1985.

Rastbeen, Ali. "The Iranian Nuclear Programme: Process and Legitimacy." In Shia Power: Next Target Iran?, by Michel Korinman John Laughland, 123-136. London : Vallentine Mitchell, 2007.

Research, Emirates Centre for Strategic Studies. Iran's Nuclear Program: Realities and Repercussions . Abu Dhabi: Emirates Centre for Strategic Studies and Research, 2006.

Rublee, Maria Rost. Nonproliferation Norms: Why States Choose Nuclear Restraint. Athens, Georgia: University of Georgia Press, 2009.

Sagan, Scott D. "Why Do States Build Nuclear Weapons?: Three Models in Search of a Bomb." International Security 21, no. 3 (1996-97): 54-86. 
Sahabi, Fereydoon, interview by Sergei Barseghian. Nagoftehayi az tatili-ye barnamehhaye hasteh-iye Iran (The Untolds of the Abandoning of the Iranian Nuclear Program) (September 7, 2007).

Samore, Gary. Iran's Strategic Weapons Programme: A Net Assessment. London: International Institute for Strategic Studies, 2005.

Shahram Chubin, Sepehr Zabih. The Foreign Relations of Iran: a developing state in a zone of great-power conflict. University of California Press, 1974.

Shirley, Edward G. "Iran Policy Trap ." Foreign Policy, no. 96 (Fall 1994).

Sick, Gary. "Iran: the adolescent revolution ." Journal of International Affairs 49, no. 1 (Summer 1995): 145-166.

Solingen, Etel. Nuclear Logics: Contrasting Paths in East Asia and the Middle East. Princeton, New Jersey: Princeton University Press, 2007.

Squassoni, Sharon. Combating Weapons of Mass Destruction: The Future of International Nonproliferation Policy (Studies in Security and International Affairs). Edited by Daniel H. Joyner Nathan E. Busch. Athens, Georgia: University of Georgia Press, 2009.

Takeyh, Ray. Guardians of the Revolution: Iran and the World in the Age of the Ayatollahs. Oxford University Press, 2009.

—. Hidden Iran: Paradox and Power in the Islamic Republic. New York: Times Books, 2006.

Takeyh, Ray, and Vali Nasr. "The Costs of Containing Iran: Washington's Misguided New Middle East Policy." Foreign Affairs (The Council on Foreign Relations), JanuaryFebruary 2008.

Vladimir A. Orlov, Alexander Vinnikov. "The Great Guessing Game: Russia and the Iranian Nuclear Issue." The Washington Quarterly (The Center for Strategic and International Studies and the Massachusetts Institute of Technology) 28, no. 2 (2005).

Waltz, Kenneth N. "Peace, Stability, and Nuclear Weapons." UC Berkeley, Policy Papers, Institute on Global Conflict and Cooperation. UC Berkeley, Policy Papers, Institute on Global Conflict and Cooperation, 1995.

Wæver, Barry Buzan and Ole. "Macrosecuritisation and security constellations: reconsidering scale in securitisation theory." Review of International Studies, 2009: 253276. 
Yossi Melman, Meir Javedanfar. The Nuclear Sphinx of Tehran. New York, NY: Basic Books, 2008.

Younger, Stephen M. "Nuclear weapons in the twenty-first century." Internal Reposrt, Los Alamos National Laboratory, 2000.

Zaborski, Jason. "Deterring a Nuclear Iran." The Washington Quarterly (The Center for Strategic and International Studies and the Massachusetts Institute of Technology) 28, no. 3 (2005): 153-167. 
VITA

\title{
MOHAMMAD HOMAYOUNVASH
}

\author{
BORN: TABRIZ, IRAN
}

2001

Bachelor of Arts in Linguistics

Allameh Tabatabai University

Tehran, Iran

2003

Master of Arts in International Relations

Allameh Tabatabai University

Tehran, Iran

2006-2009

Presidential Fellowship

Florida International University

Miami-FL

2009-present

Adjunct Instructor

Florida International University

Miami, FL

Academic and Professional Conference Presentations:

- "Shi'a Ethics and The Atom Question: Contours of the Unfolding Debate;" Paper presented at 2011 MESA Annual Convention; Washington D.C., January 1-4, 2011.

- "Comparative Nuclear Ethics: Christianity, Islam, and Hinduism;” Paper presented at 2011 ISA Annual Convention; Montreal, Quebec. March 16-19, 2011.

- "The Iranian Nuclear Program and its Transformative Impact on International Nonproliferation Discourse;" Paper presented at 2010 ISA West Annual Convention; Los Angeles, California; September 24-25, 2010.

- 'Russia's Maverick Approach Toward Iran's Nuclear Program and Its International Security Implications;" Paper presented at 2010 ISA Annual Convention; New Orleans, Louisiana; February 16-21, 2010. 